\title{
The Role of Hong Kong's Financial Regulations in Improving Corporate Governance Standards in China Lessons from the Panama Papers for Hong Kong
}

\author{
Bryane Michael, University of Hong Kong and \\ Say Goo, University of Hong Kong
}

1 November 2016

\begin{abstract}
Hong Kong contributes to poor corporate governance on the Mainland. Could regulatory reform in Hong Kong help improve corporate governance standards/practices (and thus firm value) on the Mainland? In this paper, we discuss ways to incentivize Mainland firms to improve their corporate governance by adopting numerous market-value increasing reforms in Hong Kong. These include the limited extra-territorial application of corporate governance provisions, changes to the Listing Rules to 'contract' for better corporate governance, and incentives to collect better corporate governance data. Other reforms include increasing financial transparency (particularly about corporate ownership and control), reducing financial firms' incentives to trade in shell corporations, regulating relationships with tax havens, and encouraging the redrafting of China's 2002 Code of Corporate Governance. We provide 31 recommendations and estimate that these recommendations can increase market values on the Mainland by $7 \%$ (or in value of roughly \$330 billion), while improving the value-added of Hong Kong’s own incorporation/corporate services companies.
\end{abstract}

Keywords: Chinese corporate governance, extra-territoriality, Hong Kong, Listing Rules. JEL codes: G34, N25, M14

Acknowledgement: We gratefully acknowledge the Hong Kong Theme-Based Research Grant Scheme for support. Faults with the paper belong to us alone. Errors of course remain our own.

Disclaimer: This paper represents a summary of salient research on our question. We do not consider the practicality or opinions of government officials in Hong Kong or the Mainland in making our recommendations. Readers should thus treat this research as exploratory, rather than as a consulting report. These reflect our own private views (to the extent that summarising others' research and data constitutes private views), and not all co-authors may agree with all the content in the paper. 


\section{Contents}

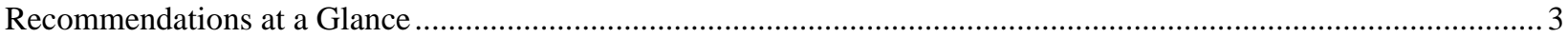

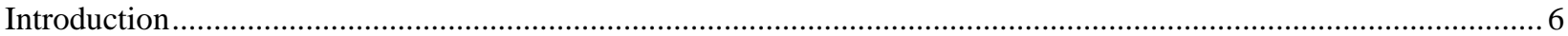

Understanding China's Corporate Governance and its Effects on Investors ..................................................... 8

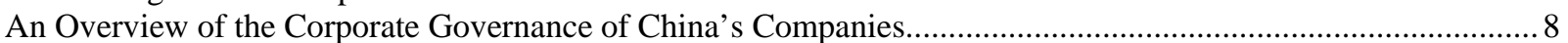

The link between corporate governance and investor returns ................................................................. 11

Chinese Firms, Tax Evasion and Offshore Incorporation Centres ............................................................. 15

What Do We Know About Chinese Corporate Governance, Demand for Offshore Companies and Tax Evasion?15

What Do the Panama Papers Data Show About China’s Corporate Governance?..............................................21

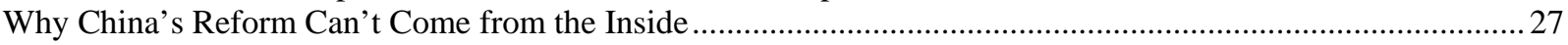

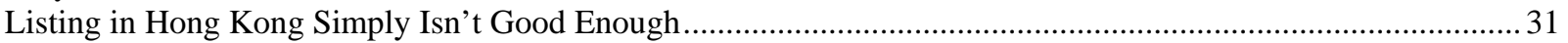

How Do We Know that Moving Hong Kong Regulations and Enforcement North Can Help? ............................37

Hong Kong's Helping Hand for the Mainland’s Corporate Governance Problems .............................................43

The Rationale for Extra-Territorial Corporate Governance Law and Rules................................................... 43

Options for Limited Cross-Border Enforcement Cooperation ..............................................................48

Hong Kong's Contribution to the Share-Price-Raising Transparency of China's Corporate Governance.................. 53

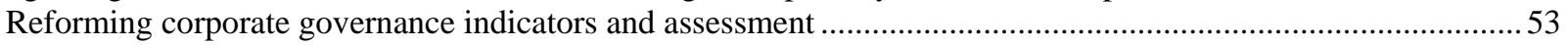

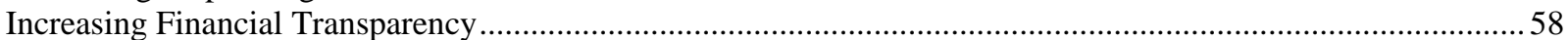

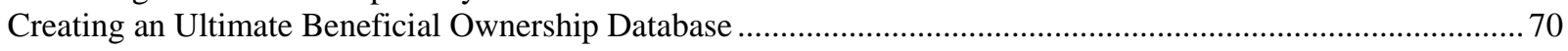

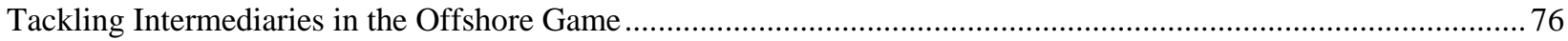

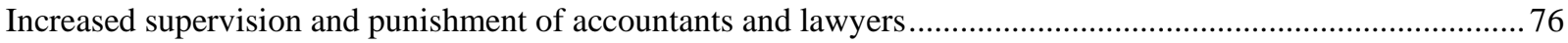

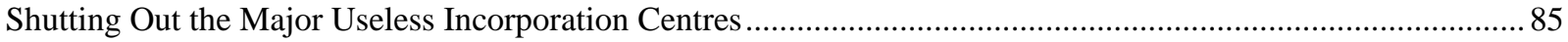

Updating China's Code of Corporate Governance and Other Regulations .........................................................93

Creating Winners Among Chinese Share Investors and Compensating Hong Kong's Losers .................................99

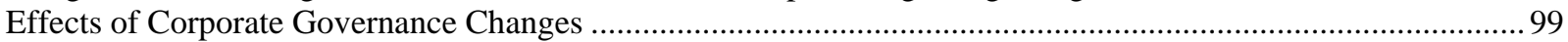

Profitably Redirecting Hong Kong's Incorporation Agents/Services Firms ............................................... 101

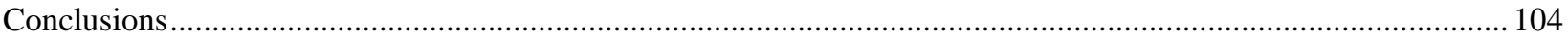




\section{Recommendations at a Glance}

Recommendation 1: Add extra-territoriality to the Companies Ordinance (in a new sec. 2(7)) and Securities \& Futures Ordinance (in a new 3(5)), if even as signal of intent, covering key corporate governance provisions from the Listing Rules.

Recommendation 2: Add requirements in section 68.1(g) and a new article 70.1(c) of the Companies Ordinance to require the dissemination of a corporate governance code with incorporation documents as well as require senior company officials sign a declaration noting that they have read the code and agree to follow the code.

Recommendation 3: Ditch comply-or-explain as well as add specific administrative, civil and criminal sanctions to the Securities and Futures Ordinance (if the SFC does not already have related rulemaking power) for violations of corporate governance provisions, as suggested in figure 37 of this paper.

Recommendation 4: Make the implicit agreement to accept extra-territorial investigations and punishment explicit by amending the legislatively adopted Code of Corporate Governance to require Listed Companies to contractually agree to the terms and conditions of Hong Kong's corporate governance rules.

Recommendation 5: Add a phrase Chapter 2 article 2.07 and in the first section of Appendix 14 clearly signalling the intent to apply extra-territorially corporate governance related Listing Rules.

Recommendation 6: The Financial Services Development Council should recommend an organisation to organise and set up procedures for corporate governance peer review between governments in the region (and especially the Mainland) based on the OECD's Guidelines or possibly under the aegis of the OECD's cooperation with non-member countries.

Recommendation 7: Add to the Listing Rules the requirement to publish enough information in corporate governance reports to allow for third-party assessment of corporate governance using the OECD Guidelines.

Recommendation 8: Hong Kong Stock Exchange (HKEx) to start talks with Asian Corporate Governance Association (ACGA) and its funder CSLA, and allocate budgetary resources out of profits for, funding the publications their assessment criteria, data and work with business/academic community to ensure rigorous, comparable data.

Recommendation 9: Hong Kong Stock Exchange should provide HK\$1 million as part of its cooperation with the ACGA and CSLA (until financial independent) to conduct corporate governance monitoring contingent on modifying its assessment methodology to reflect OECD standards and an internal audit to ensure the integrity of its scoring process.

Recommendation 10: The Hong Kong Trade Development Council (or other suitable body) should endorse the right to information as a core value in companies' mission statements. 
Recommendation 11: The SFC implements its ratification the IOSCO Principles of Disclosure perhaps through a Guidance document), continue implementing the Financial Stability Board's recommendations on disclosure and report publicly about the quality of firms' disclosure practices.

Recommendation 12: Mandate the SFC's Corporate Disclosure Team to advise those looking for information (or complaining about a lack of information) as well as companies looking for information on disclosure.

Recommendation 13: The Securities and Futures Commission should produce a booklet advising persons harmed by a lack of disclosure/transparency and/or relying on such disclosures to recoup damages and complain about un-transparent practices.

Recommendation 14: Unilaterally require the provisions of the Open SOE Information Bill (or the OECD Guidelines on Corporate Governance of State-Owned Enterprises as relevant) for state-owned Mainland corporates listed in Hong Kong.

Recommendation 15: Include the need to have an SOE disclosure and transparency policy as part of the disclosure rules for SOEs, and provide best practice guidance from the OECD or other qualified body.

Recommendation 16: Financial Services and Treasury Bureau conducts and publishes a money laundering risk assessment in line with those conducted by the US, UK and Japan in order to identify and quantify the risks from beneficial ownership fraud.

Recommendation 17: Financial Secretary's Office to work with the Hong Kong Monetary Authority, the Securities and Futures Commission, and the Financial Services and the Treasury Bureau to adopt rules for collecting and sharing beneficial ownership information, with the UK as a possible model (or at least a published road map for adopting such legislation).

Recommendation 18: Put a beta version of such a beneficial ownership register online.

Recommendation 19: Eventually adjust the Solicitors Practice Ordinance, Professional Accountants Ordinance and the Companies Ordinance to reflect the obligation/right for professional services firms and company boards to adopt a risk-management perspective as way of dealing with compliance and risk - as well as scrutinize high-risk clients by extra monitoring.

Recommendation 20: The Law Society, the Hong Kong Institute of Certified Public Accountants and the Hong Kong Institute of Chartered Secretaries to adopt professional rules to include a presumption of transparency which discourages the supply and demand for legal/regulatory avoidance.

Recommendation 21: Introduce an explicit "legitimate economic purpose test” in article 61/61a into the Inland Revenue Ordinance (during the next major legal revision), in offshore listings, and in risk profiling clients/partners. 
Recommendation 22: Add a provision to the Hong Kong Code of Corporate Governance requiring companies to confirm that the jurisdiction they have incorporated in matches the firm's economic purpose, or explain why not.

Recommendation 23: Introduce rules in the Listing Rules companies from jurisdictions (or companies which transact with them) which require additional due diligence and a classification as a high risk entity if that company's jurisdiction allows or encourages: a) mailbox company colonies, b) foreign-only operation and c) directors and shareholder meetings with individuals having little knowledge of the companies they affiliate with, and d) sale and operation of shelf companies.

Recommendation 24: Introduce a provision in the Code of Corporate Governance to require companies conducting any transactions with a shell company, offshore company from the BVI, Cayman Islands, Bahamas, or other jurisdictions decided by the HKEx to disclose such business and the nature of that business.

Recommendation 25: Require SPV at end of company name (like Limited) to designate that the entity is a special purpose vehicle.

Recommendation 26: Require offshore, shell/shelf, special purpose vehicles, and "hollow" holding companies to issue corporate governance reports outlining their operations in the same way that normal companies do.

Recommendation 27: The FSDC should consolidate the numerous CSRC, Company Law and other rules into unified rulebook (as a goodwill gesture).

Recommendation 28: The FSDC should provide non-authoritative Guidance from the Hong Kong perspective for principles outlined in the Mainland's 2002 Code of Corporate Governance.

Recommendation 29: The FSDC should encourage the CSRC to adopt relevant provisions from the Hong Kong Code of Corporate Governance to the Mainland's.

Recommendation 30: Implement the recommendations of our last assessment of Hong Kong's corporate governance to tackle concentrated ownership, institutional activism, self-dealing, and Board development in Hong Kong itself.

Recommendation 31: The Hong Kong Institute of Chartered Secretaries to conduct workshops preparing small incorporation agents and intermediaries to move up the value chain or exit the market. 


\section{The Role of Hong Kong's Financial Law in Improving Corporate Governance Standards in China: Lessons from the Panama Papers for Hong Kong \\ Bryane Michael, University of Hong Kong and \\ Say Goo, University of Hong Kong}

The regulators may explore additional ways to expand Hong Kong's "regulatory reach" by means of reciprocal enforcement or cooperation arrangements with key territories. ${ }^{1}$

- Hong Kong Financial Services Development Council

\section{Introduction}

What sane investor would place money in Mainland securities? The investor-blogger circuit has compiled lists of literally hundreds of recent Chinese stock scams. ${ }^{2}$ Most of these frauds involve three elements. First, poor corporate governance (often despite a foreign listing in the US or Hong Kong). Second, incorporation in an offshore secrecy jurisdiction (with the Cayman Islands, Bermuda, and the British Virgin Islands being some of the most popular). Third, inaction by Mainland securities regulators and law enforcement. Examples range from Ming Zhao of Puda Coal, ZTE's circumvention of export restrictions to Iran, and the Bank of China's refusal to turn over customer information in a counterfeiting case. ${ }^{3}$ Academics have quantified the harm such fraud reeks on share prices and demand for Chinese shares. ${ }^{4}$ What if the Mainland could import some of the confidence that Hong Kong's investors place in their publicly traded securities?

In this paper, we explore ways that Hong Kong law could contribute toward improving corporate governance on the Mainland. Making Mainland companies' CEOs fear enforcement action by the Hong Kong Stock Exchange (HKEx) and the Securities and Futures Commission (directly or through Mainland counterparts) represents one way to improve Mainland corporate governance. ${ }^{5}$ Yet, as shown by the Panama Papers scandal and other scandals, Hong Kong's financial regulations are not blameless in Chinese stock fraud scandals. ${ }^{6}$ Hong Kong contributes to some

\footnotetext{
${ }^{1}$ Hong Kong Financial Services Development Council, Positioning Hong Kong as an International IPO Centre of Choice, FSDC Paper 9, 2014, at 4.3.2, available online.

${ }^{2}$ We cite these sites not to suggest that they provide completely reliable information. Yet, the presence of these lists, their popularity and the extent that investors see and believe these lists, point to likely harms in investors' confidence. See Kreuzroads, Global List of Chinese Stock Frauds, 2013, available online. See also Chinastockfraud.com, Chinese Stock Fraud, Beware of Chinese Stock Scams -They Are Real: Understand Chinese Stock Frauds, 2014, available online.

${ }^{3}$ See Harris, Dan, Buying Stock in China’s Publicly Traded Companies: Good Luck With That, China Law Blog, 2016, available online.

${ }^{4}$ These harms range from quite a lot to none. For an example of the first perspective, see Darrough, Masako, The Spillover Effect of Fraud Allegations Against Chinese Reverse Mergers, 2015, available online. For an example of the second perspective, see also Lee, Charles, Kevin Li and Ran Zhang, Shell Games: The Long Term Performance of Chinese Reverse Merger Firms, The Accounting Review 90(4), 2015, available online.

${ }^{5}$ Readers will see HKEx and SEHK alternatively in much of the literature. The SEHK represents the stock exchange "proper," while the HKEx represents a holding company with several exchanges as subsidiaries. Following usual convention in Hong Kong, we will use HKEx to the exchange (as the other exchanges clearly do not touch on our research topic). For more information, see HKEx, History of HKEX and its Market, 2016, available online.

${ }^{6}$ We refer to the Panama Papers data in this paper as data from the International Consortium of Investigative Journalists' (ICIJ) Offshore Leaks Database. The database includes information from the Panama Papers, the
} 
of the poor corporate governance on the Mainland - given Mainland companies' use of Hong Kong and offshore incorporation centres to mislead investors at home and abroad. The Panama Papers leak showed all too clearly the importance of cleaning up Hong Kong's participation in the schemes allowing Chinese companies' insiders to dup investors. Once cleaned up, Hong Kong's regulators can join as a key member of the international community's push for more extra-territorial application of securities law and enforcement. ${ }^{7}$

In this paper, we argue for a combination of more aggressive extra-territorial application of Hong Kong's corporate governance-related securities regulations and exercising more bargaining power over foreign companies listed and/or working in Hong Kong. Hong Kong's leadership on world securities markets - and on securities/law enforcement "markets" - can help improve corporate governance on the Mainland and increase valuations on the Mainland while solidifying Hong Kong's position as an international financial centre. Section I provides an overview of the corporate governance problems on the Mainland. We show how such problems stem partly from tax evasion and insider dealing. We also show the need for cross-border (or extra-territorial) action - as change will unlikely come from within the Mainland itself. Section II shows the evidence on the cross-border enforcement of corporate governance provisions. We describe current law (and lack of extra-territoriality) as well as limited work with foreign regulators. We discuss how the HKEx might serve as a party in righting corporate governance wrongs on the Mainland. Section III shows how Hong Kong might achieve such over-the-border enforcement of its value-enhancing corporate governance principles for Hong Kong listed (or otherwise financed) Mainland companies. ${ }^{8}$ We describe changes to Hong Kong's listing rules and other rules which would impact on Mainland corporations' corporate governance practices. Hong Kong can leadby-example by requiring the declaration of beneficial owners and greater transparency. We show how our reforms could lead to a 7\% uptick in Mainland companies' valuation as well as describe how to compensate Hong Kong's incorporation and company secretarial services companies who lose as a result of these generally market-improving reforms.

We should start this paper with a few caveats. First, we describe reforms often mentioned in academic and policy circles regardless of their feasibility or political desirability in Hong Kong and the Mainland. ${ }^{9}$ Second, we must sacrifice some rigour to make our exposition understandable to a wider audience. We refer to the HKEx (instead of the SEHK), the Panama Papers data (which includes data from Offshore Leaks and Bahamas Leaks) and do not fully report on our own statistical analyses in other keep the reader away from long-winded sentences. Third, different authors contributed different parts of this paper. Building consensus among the authors on all the recommendations would cause us to remove and water-down many of them. Thus, we

Offshore Leaks and the Bahamas Leaks. Yet, we refer to Panama Papers only as a short-hand for these combined search results to make our paper easier to read.

${ }^{7}$ Calls for increased extra-territorial enforcement of corporate governance has increased in recent years. Maybe someday, jurisdictions will apply corporate governance rules’ extra-territorially as ubiquitously as such application in anti-trust and anti-corruption law. See Kirshner, Jodie, A Call for the EU to Assume Jurisdiction over Extraterritorial Corporate Human Rights Abuses, Northwestern Journal of International Human Rights 13(1), 2015, available online.

${ }^{8}$ Such a tentative phrasing of this sentence allows for greater regulation and enforcement of corporate governance rules in debt finance and private placements (someday).

${ }^{9}$ Readers should consult Leng for a discussion of how China's politics of gradual reform make our proposals harder than we make them seem. See Leng, Jing, Corporate Governance and Financial Reform in China's Transition Economy, HKU Press, 2009. 
try to present recommendations resulting from the broader literature without necessarily fully buying them personally. Readers should use information they find help, and ignore the rest.

\section{Understanding China's Corporate Governance and its Effects on Investors}

\section{An Overview of the Corporate Governance of China's Companies}

The data show that the Chinese Mainland's companies have a lot to learn from other jurisdictions like Hong Kong about improving their corporate governance. ${ }^{10}$ Figure 1 shows the gap between standard indices of the quality of China's and Hong Kong's corporate governance. ${ }^{11}$ The quality of the Mainland's corporate governance remains low - despite significant reform over the last $15+$ years. ${ }^{12}$ Both the rules themselves, as well as their enforcement, lag behind jurisdictions like Hong Kong and/or Singapore. Figure 2 shows China's companies' corporate governance scores by each of the dimensions identified in the OECD's Corporate Governance Principles. ${ }^{13}$ The worst companies score lowly on giving the firms' stakeholders and the supervisory board a say in corporate governance. Even the worst of the batch score reasonably well on information disclosure and transparency. Chinese corporate governance seems to focus on shareholders - with companies earning the highest scores among the set for fairness to shareholders. China's corporate governance laws and policies have focused on shareholders rights to the likely detriment of other groups, like the empowerment of boards, supervisors and other stakeholders needed to make the Mainland's corporate governance reflect in share price valuations.

\footnotetext{
${ }^{10}$ Throughout this paper, we try to refer to China (excluding Hong Kong and Macao) as the Mainland. We follow this Hong Kong convention, as most of our comparisons deal with Hong Kong versus the Mainland. Inadvertent slips, calling the Mainland "China” or referring to Hong Kong as a country rather than a jurisdiction, reflect our haste rather than some deep-seated political views.

11 The Asian Corporate Governance Association could serve a far more useful role in promoting corporate governance across the region by releasing its data to the public. For now, though, we must find data when rarely presented to the public. See Allen, Jamie, CG Watch 2014 - Market Rankings, Asian Corporate Governance Association Presentation, 2015, available online.

12 The summary statistics we show here can not compare with the deep insights that in-depth scholarly analysis of Chinese corporate governance provides. See Kang, Yong, Lu Shi, and Elizabeth Brown, Chinese Corporate Governance: History and Institutional Framework, Rand Corporation Technical Report 618, 2008, available online.

${ }^{13}$ For the description of the questions used to assess each area, see OECD, G20/OECD Principles of Corporate Governance, 2015, available online. For the data, see Protiviti, Corporate Governance Assessment Summary Report on the Top 100 Chinese Listed Companies for 2012, 2013, available online. For a summary of the OECD’s questions (put into convenient tabular Q\&A form), see Tong, Lu, Ji-yin Zhong, and Jie Kong, Corporate Governance Assessment on the Top 100 Chinese Listed Companies, 2006, available online.
} 


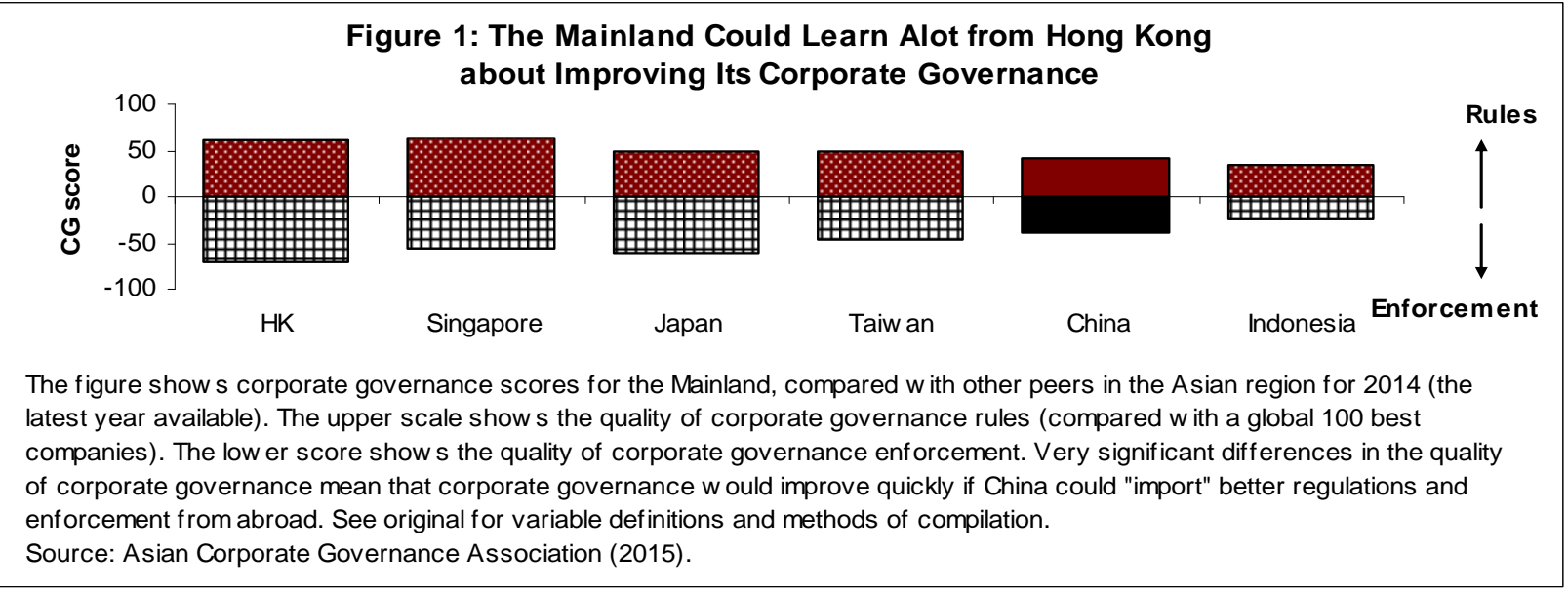

Figure 2: Chinese Corporate Governance Only at $37 \%$ of the World's Highest Standards

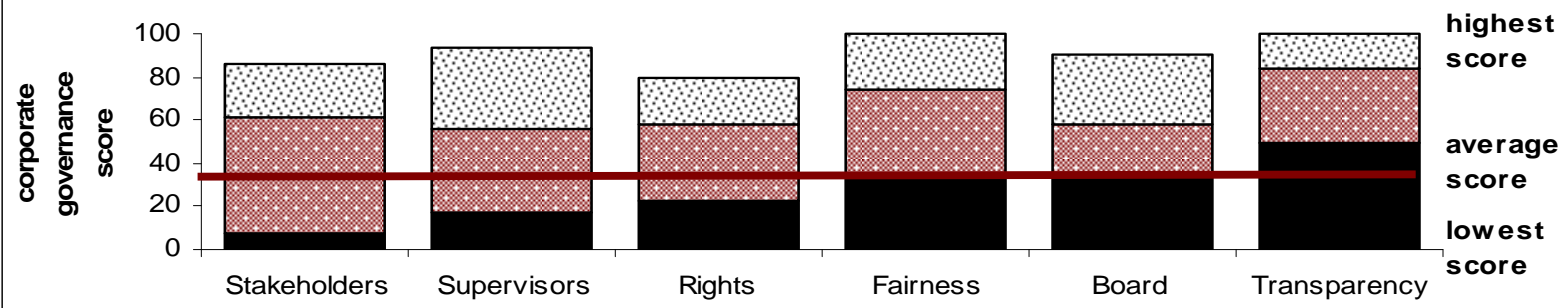

The figure shows the corporate governance scores among the largest 100 listed Chinese companies for the areas of corporate governance mentioned in the figure. The red line show s the average across categories. The black bars show the low est score (for stakeholder participation for example, the low est scoring company only earned 7 out of 100 points).

Source: Protiviti (2013).

The variation in corporate governance scores among Chinese firms represents a far more disconcerting trend than the low average scores earned by these companies. Chinese companies score badly on each dimension of corporate governance - with an average corporate governance score of around $37 \%$ out of the 100\% earned by companies completely implementing the OECD Principles (as shown above in Figure 2). Yet, Figure 3 shows the very large variation in corporate governance practices and performances among Chinese firms. Corporate governance scores for various companies in a range of industries can vary from $30 \%$ to $80 \%$ of best practice. The trend shows a general improvement in corporate governance practices in recent years. Yet, the large variation in these scores, both across time and across firms, indicates that China's corporate governance policies are "out of control" (in the statistical sense of the word). ${ }^{14}$ In other words, because of the large variation in corporate governance practices among Chinese firms, policymakers can not adopt policies focused on improving such governance until senior managers bring these companies’ governance practices “under control.”

\footnotetext{
${ }^{14}$ Out of control processes refer to processes which exhibit wide variation, making predicting them (and thus regulating them) more difficult. See Harp, Nancy, Mark Myring, and Rebecca Shortridge, Do Variations in the Strength of Corporate Governance Still Matter? A Comparison of the Pre- and Post-Regulation Environment, Journal of Business Ethics 122(3), 2014, available online. See also Fan, Steve and Linda Yu, Variation in Corporate Governance and Firm Valuation - an International Study, International Review of Finance (Early View), 2016, available online.
} 


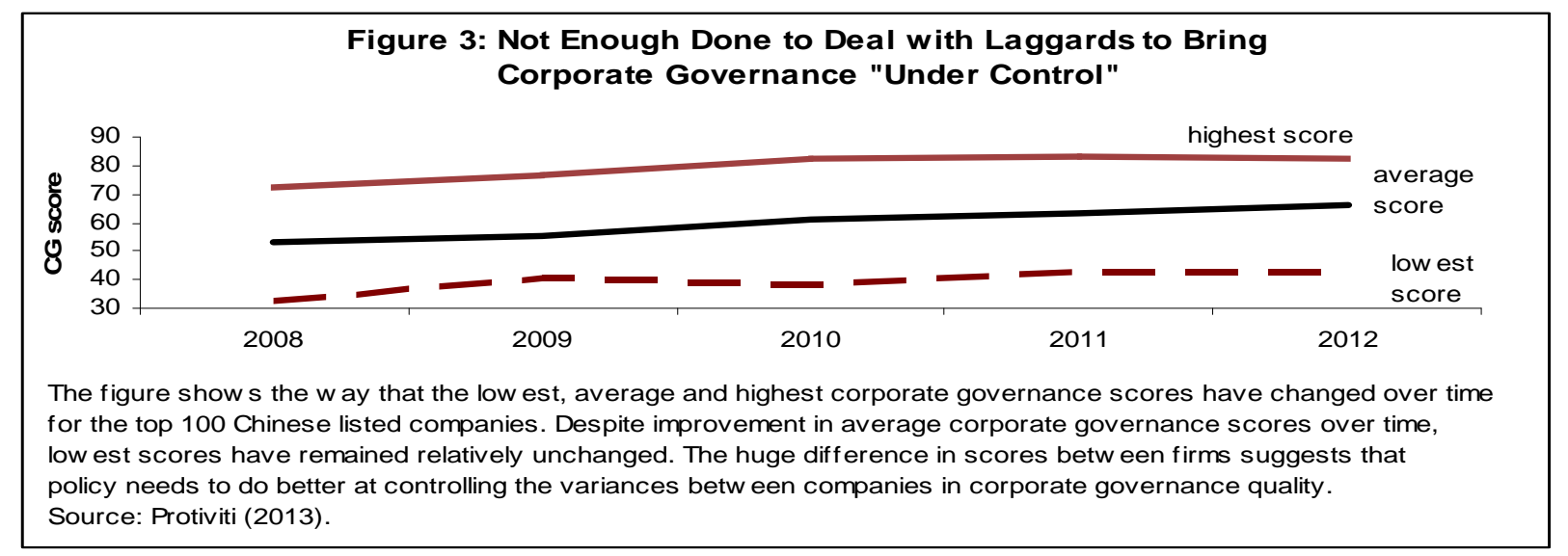

Variation in corporate governance practices across industries also points to the need for more coordinated corporate governance-related rulemaking. As shown in Figure 4, financial services firms score a reasonably good $72 \%$ out of $100 \%$. Companies in the mining, manufacturing and other sectors however, only score between $60 \%$ and $65 \%$ out of $100 \%$. The government's post2008 extra corporate governance related regulations clearly explain why the financial sector scores best. ${ }^{15}$ The financial sectors experience suggests that increased government regulation and enforcement of corporate governance rules can bring these scores "under control" and raise standards across the board.

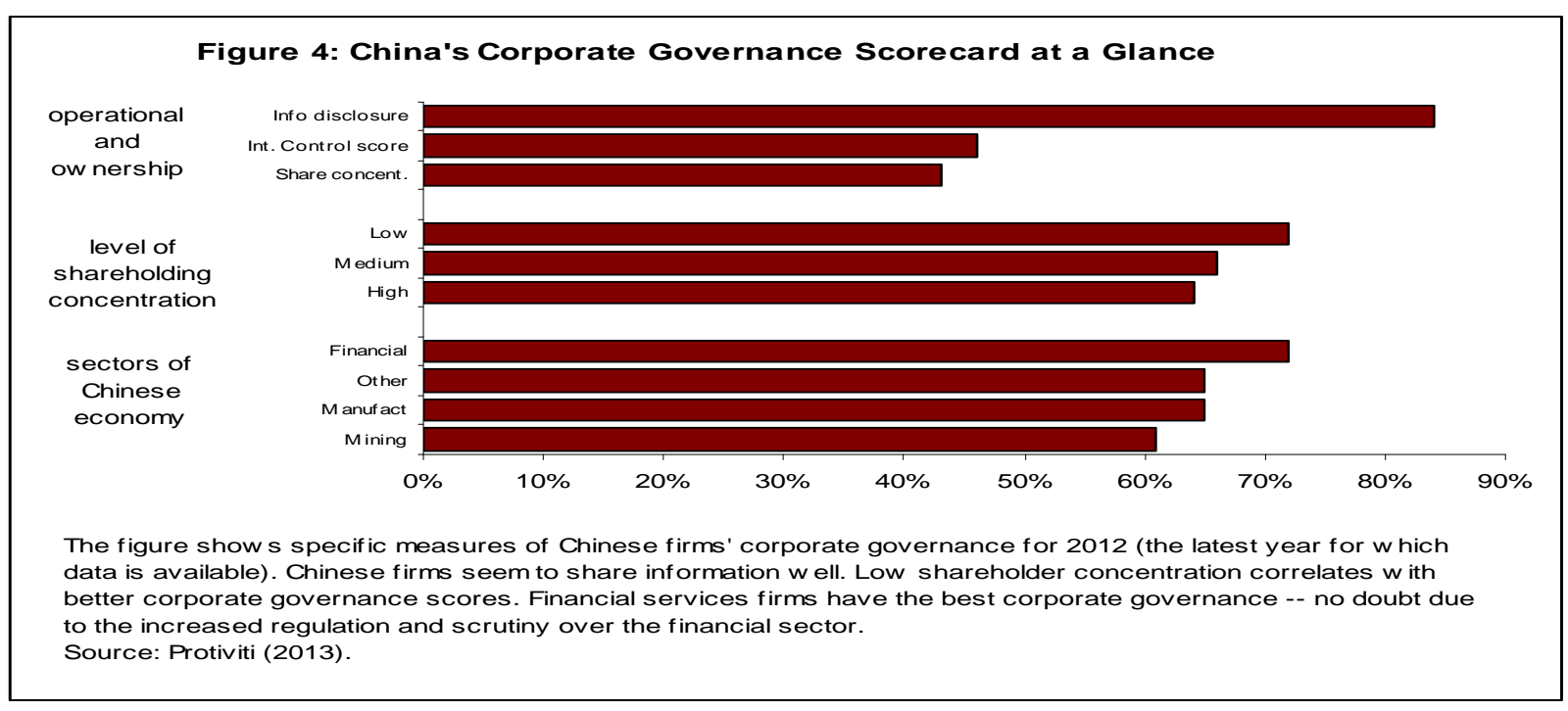

\footnotetext{
${ }^{15}$ In China, as in other jurisdictions, regulators passed a number of corporate governance and other regulations aimed at responding to the global financial crisis of 2007-2008, as well as strengthening financial institutions in the future. Interestingly, Erkens and co-authors find that good corporate governance practices exacerbated the effect of the financial crisis on financial firms around the world (including China). As such, policymakers can not rely on simply improving corporate governance as a means of promoting financial stability. They will need to draft rules that reduce risk-taking behaviour approved of by institutional investors and independent board members. See Erkens, David, Ming-Yi Hung, and Pedro Matos, Corporate governance in the 2007-2008 financial crisis: Evidence from financial institutions worldwide, Journal of Corporate Finance 18, 2012, available online.
} 
Even a rudimentary glance at various Chinese companies' corporate practices show reasons for these firms' low corporate governance scores. Figure 4 (already shown above) shows three summary statistics about governance practices among Chinese companies - the extent of information disclosure, the extent of internal control and the extent of concentration among shareholders. While information disclosure ranks highly, lower internal control scores combined with very concentrated shareholdings -- point to the large role that concentrated shareholders (rather than rules and regulations) play in governing Chinese business. Companies with high shareholder concentration have corporate governance scores of around $60 \%$. Companies with low shareholding concentration have corporate governance scores of around $75 \%$. Government policies which discourage dispersed ownership of Mainland companies account for some of poor governance practices among Chinese firms.

\section{The link between corporate governance and investor returns}

How do we know that better corporate governance practices among Chinese firms contribute to higher corporate returns? Figure 5 shows the results of simplistic (and wrong) analysis showing the simple correlation between corporate governance scores and corporate returns. Foreign companies with the highest corporate governance scores have rates of return just as low as lowscoring Chinese state owed enterprises. Such work supports other findings from academics like Cheung and co-authors' early econometric work. ${ }^{16}$ Their econometric analysis finds no relationship between corporate governance index scores and market valuation. Sector-specific work - such as studies looking at corporate governance and the performance of Chinese realestate companies - similarly find little relationship. ${ }^{17}$

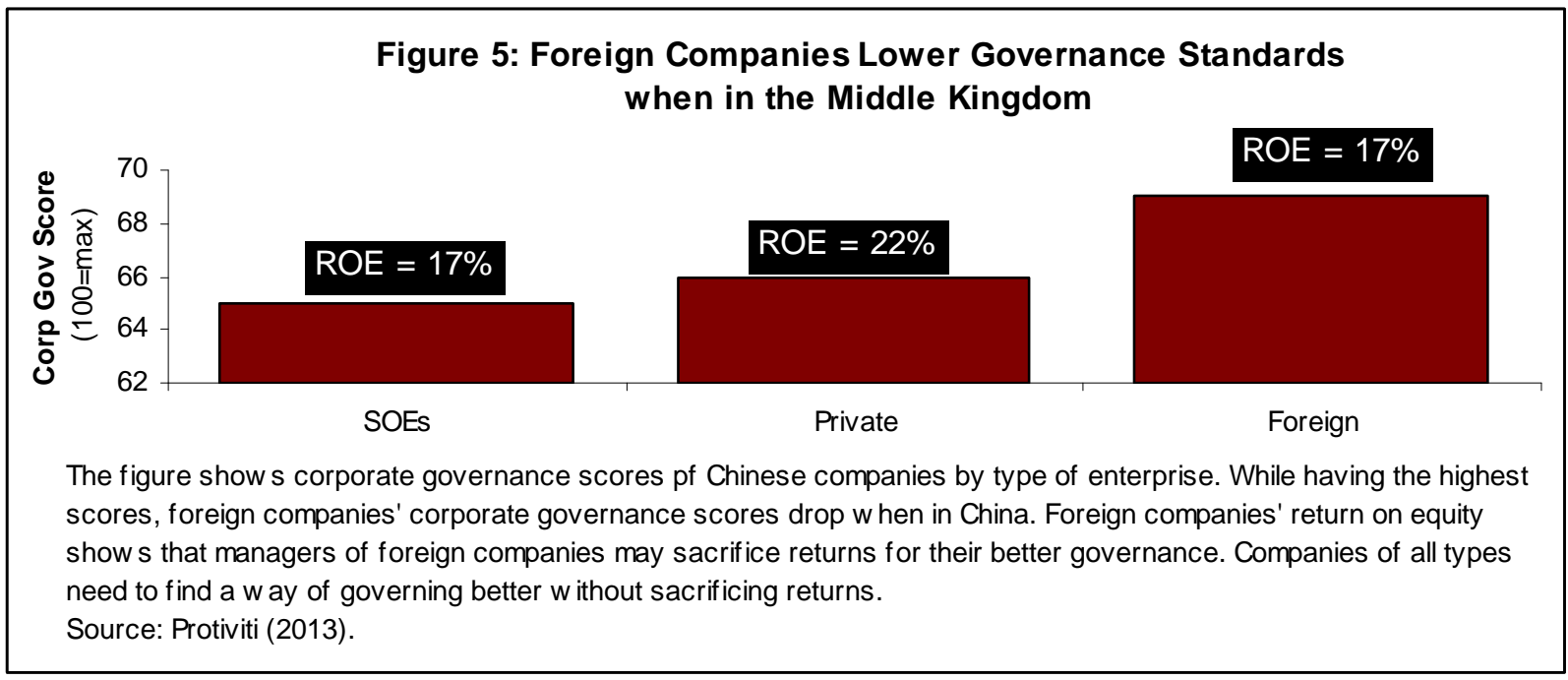

\footnotetext{
${ }^{16}$ We refer to their early work, as their later work recants on these initial findings. We provide that latter work in several paragraphs below. See Cheung, Yan-Leung, Ping Jiang, Piman Limpaphayom, and Tong Lu, Does Corporate Governance Matter in China, China Economic Review 19(3), 2008, available online.

${ }^{17}$ See Fan, Gang-Zhi, Zsuzsa Huszar, and Wei-Na Zhang, Corporate Governance in Chinese Real Estate Firms, IRES Working Paper Series IRES2014-006, available online.
} 
Yet, more credible studies do find a relationship between Chinese firms' corporate governance index values market valuations. Even before looking at these studies, Figure 6 shows an unmistakable relationship between the quality of Mainland companies' corporate governance and their Tobins' $q .{ }^{18}$ The line of best seems to show that a one-point increase in corporate governance indicators correlates with a 1 point change in Tobin's $q$ values. Figure 7 shows very similar findings - as the change in market valuations (namely Tobin's $q$ ) corresponding to changes in Chinese firms' corporate governance index values. ${ }^{19}$ As firms move from the worst to the best corporate governance practices, they add the extra value of the replacement cost of their assets. By way of illustrating the magnitude of these findings, if all Mainland listed companies moved from worst to best-in-class corporate governance, such a move would add about \$2.7 trillion in market capitalization to these firms (see figure for methodology used to find this number). Mainland firms with better corporate governance list abroad and have higher levels of disclosure (and accompanying levels of market value). ${ }^{20}$ Better Mainland corporate governance correlates to higher market valuations for Mainland companies listed in Hong Kong. ${ }^{21}$ Thus, Hong Kong's corporate governance rules can help Mainland companies cash in on their good governance on its stock market.

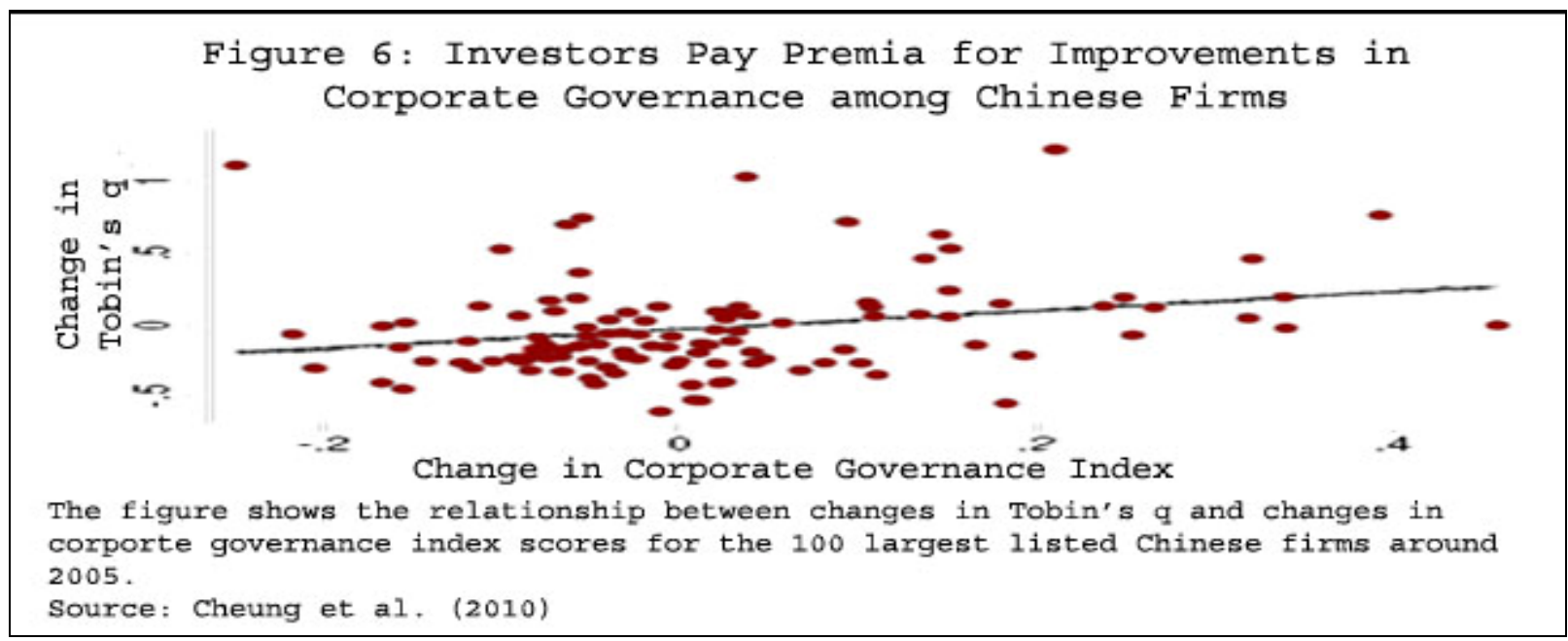

\footnotetext{
18 Tobin's q measures the extent to which companies' market valuations exceed the replacement cost of their assets (roughly speaking). Its plural is probably Tobin's qs (as there is only one Tobin). Yet, the text looks cleaner our way.

${ }^{19}$ See Bai, Chong-En, Qiao Liu, Joe Lu, Frank Song, and Jun-Xi Zhang, Corporate Governance and Market Valuation in China, William Davidson Institute Working Paper No. 564, 2004, available online.

${ }^{20}$ See Cheung. Yan-Leung, Ping Jiang, and Wei-Qiang Tan, A Transparency Disclosure Index Measuring Disclosures: Chinese Listed Companies, Journal of Accounting and Public Policy 29(3), 2010, available online.

${ }^{21}$ See Cheung, Yan-Leung, Thomas Connelly, Priman Limpaphayom and Lynda Zhou. Do Investors Really Value Corporate Governance? Evidence from the Hong Kong Market, Journal of International Financial Management and Accounting 18(2), 2007, available online.
} 


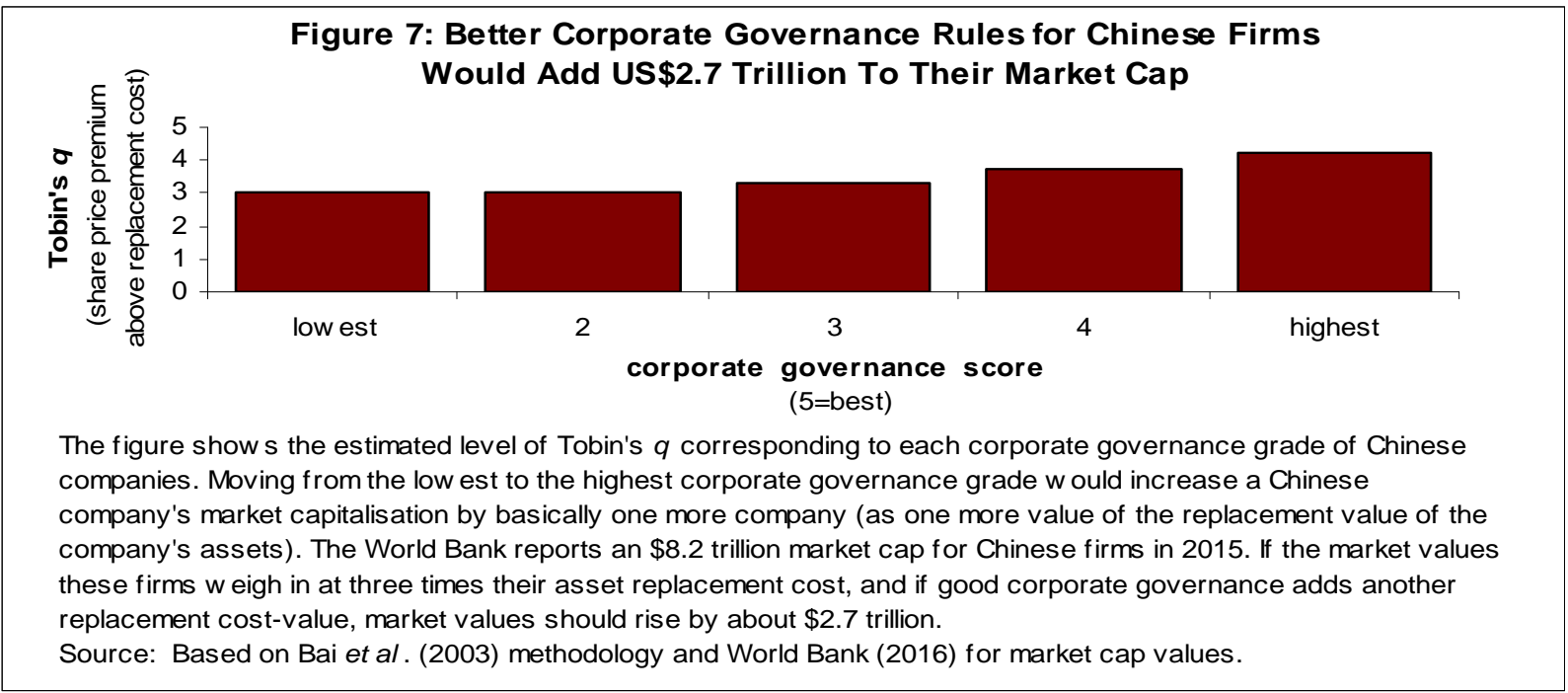

Numerous studies show the types of corporate governance relations correlating with higher market valuations. Figure 8 shows an example of a number of recent studies looking at the econometric relationship between corporate governance and firm performance. ${ }^{22}$ After controlling for other variables like market conditions, they find that foreign and institutional ownership, dispersed shareholding, effective boards and audit committees help lift firm values. Most studies confirm Bai et al.’s results - market valuations rise when non-controlling shareholders and foreigners hold a large proportion of the company's shares. ${ }^{23}$ Market valuations fall with concentrated shareholdings, when the CEO also acts as the chairperson of the board, and when government represents the largest shareholder. Even eye-balling the relationship between Tobin's $q$ and corporate governance indices for individual firms shows the positive relationship. ${ }^{24}$ Other authors like Shan and IcIver find similar evidence for non-listed firms proving that needed reforms span the Chinese corporate sector. ${ }^{25}$ Interestingly, Lin and coauthors find that the business environment in which Chinese firms compete statistically significantly affects their corporate governance practices. ${ }^{26}$ As Chinese firms increasingly list and compete in developed markets, corporate governance practices should improve. ${ }^{27}$

\footnotetext{
${ }^{22}$ See Lee, Jung-wha and Zhi-hua Zhang, Ownership Structure, Corporate Governance and Firm Value: Evidence from Chinese Listed Companies, Finance and Corporate Governance Conference 2011 Paper, 2011, available online.

${ }^{23}$ See Bai, Chong-En, Qiao Liu, Joe Lu, Frank Song, and Junxi Zhang, Corporate Governance and Market Valuation in China, Journal of Comparative Economics 32(4), 2004, available online.

${ }^{24}$ See Cheung, Yan-Leung and Ping Jiang, Piman Limpaphayom and Tong Lu, Corporate Governance in China: A Step Forward, European Financial Management 16(1), 2010, available online.

${ }^{25}$ See Shan, Yuan and Ron McIver, Corporate Governance Mechanisms and Financial Performance in China: Panel Data Evidence on Listed Non-Financial Companies, Asia Pacific Business Review 17(3), 2011, available online.

${ }^{26}$ See Lin, Chen, Yue Ma, and Dong-Wei Su, Corporate Governance and Firm Efficiency: Evidence from China's Publicly Listed Firms, Managerial and Decision Economics 30(3), 2009, available online.

${ }^{27}$ The ability to draw on different, well-heeled shareholders represents part of this benefit. Epps and Ismail show that, for Chinese firms, returns on assets decline with very concentrated and very dispersed shareholding. See Epps, Ruth and Tariq Ismail, Board of Directors' Governance Challenges and Earnings Management, Journal of Accounting \& Organizational Change 5(3), 2009, available online.
} 


\section{Figure 8: Investors Clearly Pay Premiums for Good Corporate Governance in China}

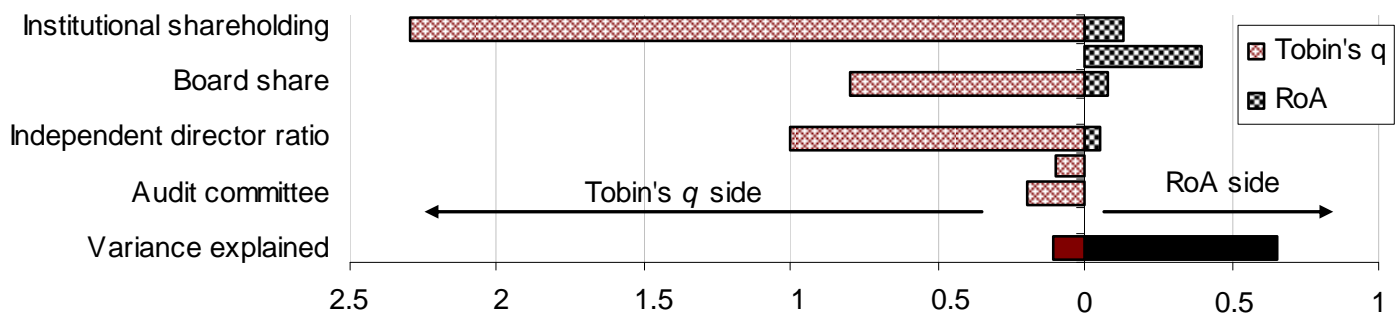

change in performance for 1 standard deviation in each of the indicators shown (all values positive)

The data show the relationship betw een several indicators related to Chinese firms' corporate governance and their performance (as measured by Tobin's q or market premium over book value) and return on assets. The data show stronger relationships betw een share price mark-ups and corporate governance (after accounting for factors like these firms' asset sizes, leverage and grow th rates) -- than for returns on assets. Yet, models of Tobin's $q$ generally have low explanatory pow er (as represented by the tiny R-squared or variance explained).

Source: Lee and Zhang (2011)

“Better” corporate governance (as commonly defined) has other advantages which indirectly promote market valuations. ${ }^{28}$ One way consists of helping to reduce the fraud and the selfdealing which makes investors nervous about investing in Mainland shares. Yeh and co-authors look at the cost of poor corporate governance in Chinese firms - showing that investors needed larger premia to buy shares in companies with poorer corporate governance ${ }^{29}$ Chen and Zhang find similarly for the 2002 Chinese Code of Corporate Governance for Listed Companies’ effect on earnings manipulation. ${ }^{30}$ In their econometric study, they find that the Code curbed earnings management by requiring independent non-executive board directors and audit committees staffed with accounting/financial experts. Firth and co-authors find that the quality of Chinese corporate governance directly affects the "occurrence and detection of financial fraud." ${ }^{31}$ Figure 9 shows the effect that corporate governance has on auditor choice - and thus the likelihood of getting away with bad governance behaviour. ${ }^{32}$ As pointed out later in this paper, supervisory boards play a key role in ensuring proper corporate conduct. Lo and colleagues reach similar conclusions - conducting econometric analysis on transfer price manipulations. ${ }^{33}$ Thus, better Chinese corporate governance indubitably leads to higher share values.

\footnotetext{
${ }^{28}$ We do not repeat the factors that constitute such good corporate governance - like dispersed shareholding, independent directors, etc - to keep our narrative tight. If we must refer to each separate component each time, the text becomes far harder to understand and remember.

${ }^{29}$ See Yeh, Yin-Hua, Pei-Gi Shu, Tsun-Siou Lee, and Yu-Hui Su, Non-Tradable Share Reform and Corporate Governance in the Chinese Stock Market, Corporate Governance 17(4), 2009, available online.

${ }^{30}$ See Chen, Jean and Hai-Tao Zhang, The Impact of the Corporate Governance Code on Earnings Management Evidence from Chinese Listed Companies, European Financial Management 20(3), 2012, available online.

${ }^{31}$ See Firth, Michael, Oliver Rui and Wen-Feng Wu, Cooking the Books: Recipes and Costs of Falsified Financial Statements in China, Journal of Corporate Finance 17(2), 2011, available online.

${ }^{32}$ See Lin, Jun and Ming Liu, The Impact of Corporate Governance on Auditor Choice: Evidence from China, Journal of International Accounting, Auditing and Taxation 18, 2009, available online.

${ }^{33}$ Lo, Agnes, Raymond Wong, and Michael Firth, Can Corporate Governance Deter Management from Manipulating Earnings? Evidence from Related-Party Sales Transactions in China, Journal of Corporate Finance 16(2), 2010, available online.
} 


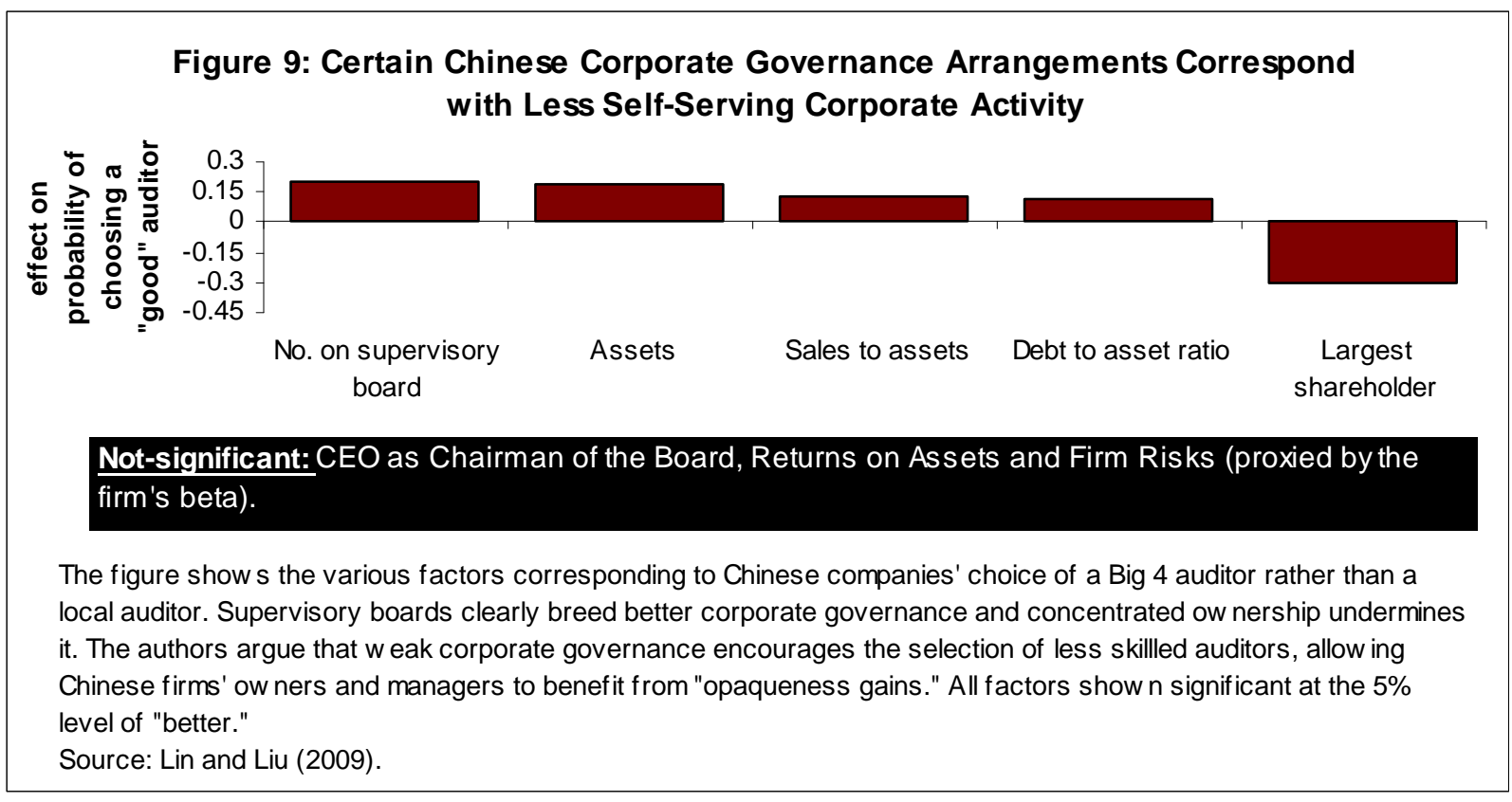

\section{Chinese Firms, Tax Evasion and Offshore Incorporation Centres}

What Do We Know About Chinese Corporate Governance, Demand for Offshore Companies and Tax Evasion?

Bad corporate governance represents a key factor in Chinese companies choosing to evade taxes, use the services of offshore secrecy jurisdictions' intermediaries and the services of organisations like Mossack Fonseca. ${ }^{34}$ Media accounts paint a picture of Chinese companies' ways and needs to use Mossack Fonseca (specifically) and offshore incorporation agents (in general). Figure 10 shows some of the facts linked with Chinese and Hong Kong incorporations (and corporate governance) cited in the Mossack Fonseca case. We can, in complete confidence, say that trillions of dollars leave China to avoid taxes (or other controls) through Hong Kong, as a result of poor corporate governance at home and abroad.

\footnotetext{
${ }^{34}$ At the time of this writing, a leak of the Panama-based law firm Mossack Fonseca's client data lead to revelations about the use of offshore companies. The wide-spread media attention paid to these data dubbed the circumstances leading to the use of Mossack Fonseca's services as the Panama Papers scandal. For more, see the International Consortium of Investigative Journalists, The Panama Papers: Politicians, Criminals and the Rogue Industry that Hides Their Cash, 2016, available online.
} 


\section{Figure 10: Chinese Corporates’ Participation in Mossack Fonseca’s Shell Game}

What is a shell company? - a non-trading corporation (or entity with tradable/transferrable interests) that does not conduct significant operations related to the transformation of inputs into marketable outputs.

Why are shell companies valuable for China's businesses? - Roughly $40 \%$ of private Chinese firms hide profits. ${ }^{35}$ Over \$1tn originated from China from 2002 to 2012, making China the world's largest illicit capital exporter. ${ }^{36}$ If Chinese firms benefitted as much as other firms, they can take capital gains profits of up to $50 \%$ quickly from listing. ${ }^{37}$

Revenue from shell company sales - Mossack Fonseca probably collected around \$8.2 million in fees for opening the 16,300 offshore companies incorporated in offices in China and Hong Kong (or roughly $30 \%$ of its “active companies worldwide”). ${ }^{38}$

Companies' management identified in the Papers - Tencent, Soho China property, Yintai, Leshi (web video), GOME appliances chain, Oceanwide, Tiens Group, Zendai investment group, Rizhao Holding, Shenzhou international, Sound global, Soundtech, Shanghai Land Holdings, and Country Garden Holdings. ${ }^{39}$

Mossack Fonseca in Hong Kong - much business handled by P\&P Secretarial Management and its British Virgin Islands registered interest Harvest Sun Trading. An accountant Wai-hon Chiu, runs P\&P. ${ }^{40}$ Roughly $1 / 3$ of all Mossfon business in Hong Kong for Mainland customers ${ }^{41}$ Wong Brothers \& Co. helped President Xi Jinping's brother-in-law Deng Jiagui to set up a BVI shell company. ${ }^{42}$ At its apogee, the firm set up 2,428 companies (in 2012).

\footnotetext{
${ }^{35}$ While authors like Liu and Xiao cite 2004 data (and earlier), these trends have not changed in the intervening decade. See Liu, Qiao and Geng Xiao, Look Who Are Disguising Profits: An Application to Chinese Industrial Firms, Hong Kong Institute of Economics and Business Strategy Working Paper 1095, 2004, available online.

${ }^{36}$ Mulrenan, Stephen, Asia: Panama Papers - No News Is Good News, International Bar Association Global Insight June, 2016, available online.

${ }^{37}$ Such "listing" refers to the reverse mergers (or backdoor listing). For data, see Floros, Ioannis and Travis Sapp, Shell Games: On the Value of Shell Companies, Journal of Corporate Finance 17, 2011, available online. See also Brown, Philip, Andrew Ferguson and Peter Lam, What's in a Shell? Analysing the Gain to Shareholders from Reverse Takeovers, 2010, available online.

${ }^{38}$ See Agence France Presse, Money and Power: China Government’s Link to Panama Papers Firm, Hong Kong Free Press April, 2016, available online.

${ }^{39}$ This list does not include the economic interests associated with the eight current or former members of China's Communist Party's Politburo Standing Committee.

See Marina Walker, Marina, Gerard Ryle, Alexa Olesen, Mar Cabra, Michael Hudson and Christoph Giesen, Leaked Records Reveal Offshore Holdings of China's Elite, ICIJ, Jan, 2016, available online.

${ }^{40}$ See Kinetz, Erika and Kelvin Chan, Hong Kong Emerges As Hub for Creating Offshore Companies, Associated Press Big Story April, 2016, available online.

${ }^{41}$ Lau, Stuart, Revealed: Panamanian law firm Mossack Fonseca's man in Hong Kong, South China Morning Post April, 2016, available online.

${ }^{42}$ See Kinetz, Erika and Kelvin Chan, Hong Kong emerges as hub for creating offshore companies, Associated Press The Big Story, 2016, available online. See also Huang, Zhe-Ping, The Panama Papers: China's elite-including Xi Jinping - are linked to offshore deals that hid millions of dollars, Quartz: Obsession, 2016, available online.
} 
What is the problem? - Recent estimates put $10 \%$ of all reverse merger listings of Chinese companies in the US as fraudulent. ${ }^{43}$ The Panama Papers implicate HSBC, a large bank with a significant presence in Hong Kong, in setting up roughly 2,300 accounts - contravening banking regulations. ${ }^{44}$ Sun Hung Kai Properties (another large Hong Kong company) could spirit away large amounts of money, even though intermediaries know the director had been convicted of corruption. ${ }^{45}$ Money laundering remains rampant in Hong Kong - fragilizing the entire financial system. ${ }^{46}$ Roughly $60 \%$ of all investment - some the result of crime or contravening foreign exchange controls -- passes through Hong Kong on its way out from China. ${ }^{47}$ In general, Chinese firms incorporating in offshore havens participate in more fraud and earn shareholders less in the longer-run. ${ }^{48}$

Source: see footnotes for sources.

To what extent have Hong Kong-based intermediaries participated in the creation of offshore corporate vehicles for Mainland companies (and those at home)? Figure 11 shows, using data from the International Consortium of Investigative Journalists (ICIJ), the time line highlighting the height of the popularity of different locations for the intermediaries who create offshore companies. $^{49}$ Panamanian intermediaries saw their heyday in the early 1990s for Hong Kong and Mainland clients. The Bahamas opened more offshore companies a few years later than subsequently in the 2000s and 2010s. The unheard-of Niue (a microscopic island in the South Pacific) also saw a brief rise in these incorporations. ${ }^{50}$ The British Virgin Islands (or BVIs) saw their heyday as a key incorporator of offshore companies around 2003. While BVI continues to handle most of Hong Kong and the Mainland's offshore incorporations, other jurisdictions (notably Samoa, Seychelles and British Anguilla in recent years) have succeeded in gaining more market share than in the past.

\footnotetext{
43 Tax Justice Network, 1 in 10 reverse mergers of Chinese firms on US stock exchanges "fraudulent", Tax Justice Network Website, 2011, available online.

${ }^{44}$ David Floyd, Panama Papers: Top 10 Banks For Offshore Companies, 2016, available online.

${ }^{45}$ See Robertson, Joshua and Paul Farrell, How a Hong Kong corruption scandal sparked strife at Mossack Fonseca, Guardian, April, 2016, available online.

${ }^{46}$ See Holland, Tom, How Hong Kong makes it easy for wealthy Chinese to launder billions of dollars, Hong Kong Free Press April, 2016, available online.

${ }^{47}$ See Garcia-Herrero, Alicia, Le Xia and Carlos Casanova, Chinese outbound foreign direct investment: How much goes where after round-tripping and offshoring? BBVA Working Paper, 15/17, 2015, available online. See also Kar, Dev and Sarah Freitas, Illicit Financial Flows from China and the Role of Trade Mis-invoicing, Global Financial Integrity, 2012, available online.

${ }^{48}$ As if the belabour the point, Siegel and Wang show how incorporation in an offshore haven like Nevada correlates with fraud more often for Chinese companies engaging in backdoor listings in the US. See Siegel, Jordan and YanBo Wang, Cross-Border Reverse Mergers: Causes and Consequences, Harvard Business School Publication 12-089, 2014, available online.

${ }^{49}$ For data source, see ICIJ, Offshore Leaks Database, 2016, at search jurisdictions for China and Hong Kong, available online.

${ }^{50}$ Van Fossen talks about the brief rise and fall of Niue as an offshore financial centre. Clearly, Hong Kong and Mainland clients shared in that rise and fall. See Van Fossen, Anthony, Tax Havens, at Chapter 2, 2012.
} 


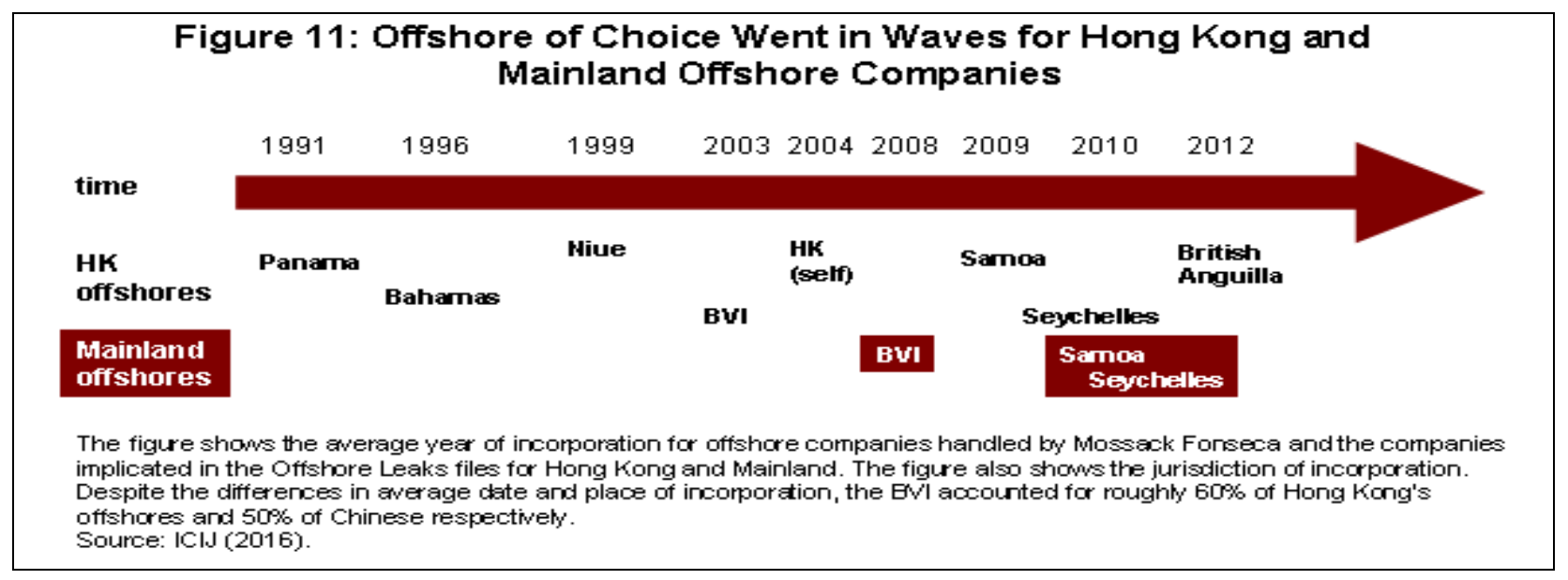

Such offshore incorporations have benefitted a wide range of China's cities (and the businesses/businesspersons in them). Figure 12 shows the location of offshore intermediaries' Mainland clients. Unsurprisingly, most demanders of offshore companies hailed from Beijing and Shanghai. Yet, even companies and individuals in Foshan and Nanchang participated in the offshore incorporation market. As this geography shows, demand for offshore companies spread around China as a way of evading taxes, bypassing capital controls, and safeguarding personal/company assets from seizure by law enforcement. Other sources provide data about China's high net worth individuals, supporting the conclusion of increasing geographical dispersion in the use of offshore companies and wealth. ${ }^{51}$ Figure 13 provides a simple illustration of the link between offshore incorporations and wealth on the Mainland. Random chance can not explain the very tight fit between the number of offshore incorporations in selected Chinese cities and the number of millionaires in those cities. ${ }^{52}$ We can not know for sure which factor represents the chicken...and which the egg. Yet, these data strongly suggest that millionaires (and their wannabes) have few incentives to improve corporate governance in their companies.

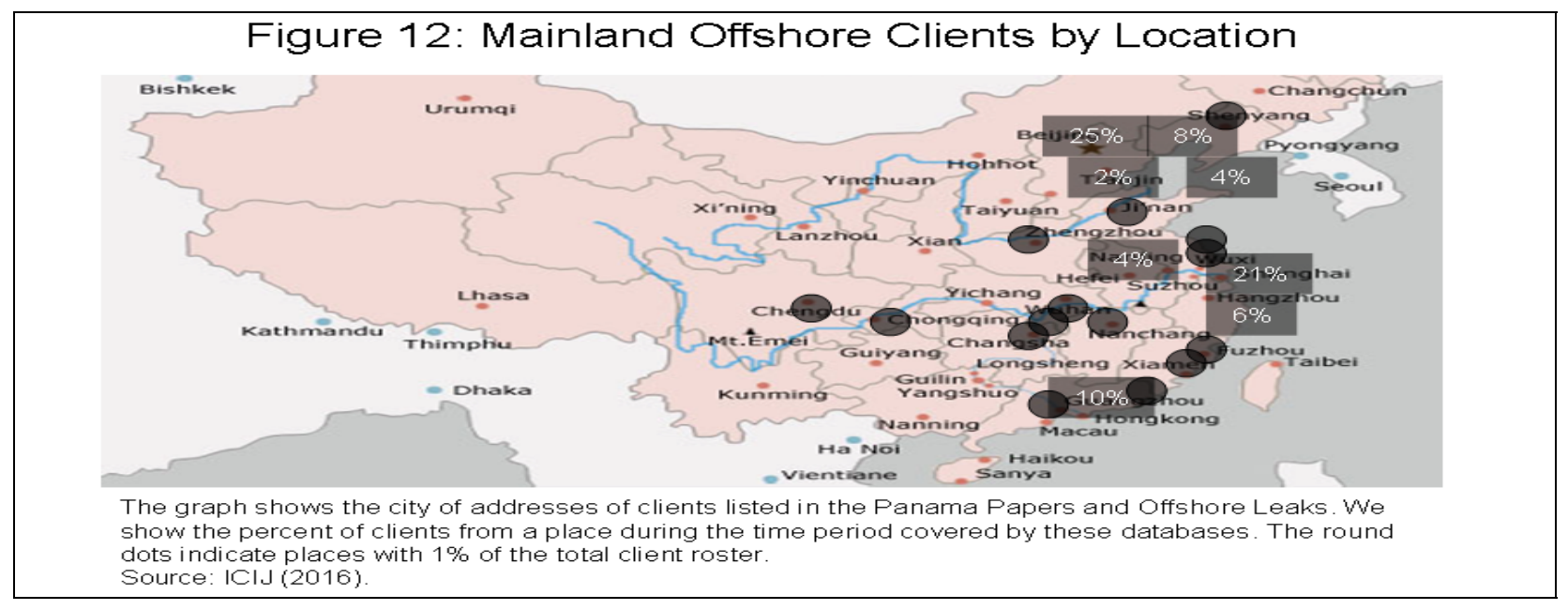

\footnotetext{
${ }^{51}$ See Hurun Research Institute, Hurun Wealth Report 2014, 2014, available online.

${ }^{52}$ In other words, the probability that no correlation exists between these variables do not significantly differ from zero. We do not show the exact statistics related to testing whether the correlation is zero - as this unnecessarily complicates our paper.
} 


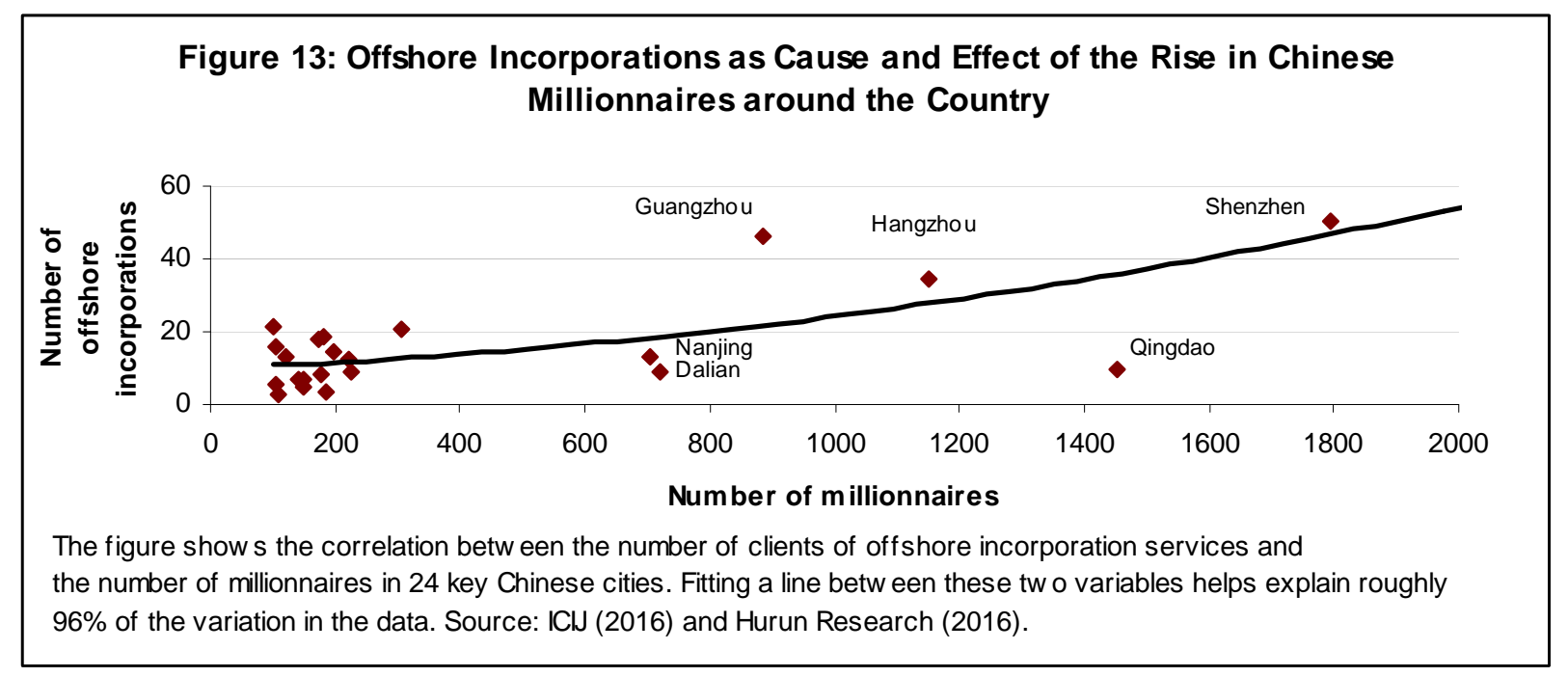

How much money do Chinese companies hide? As early as 2004, authors like Liu and Xiao, found significant tax avoidance among Chinese companies of up to $16 \%$ of profits. ${ }^{53}$ Private firms report profits rates of around 8\%. Other types of firms reporting profits of only $4 \%$ probably mis-represent their profits. If only ownership types differ between these companies, we can deduce that, on average, these other (non-private) firms must be hiding $4 \%$ of their profits. ${ }^{54}$ Such under-payment defies the received wisdom about SOEs' tax payments - as they may indeed, seek to pay taxes, given these taxes' effect on SOE managers' promotion potential ${ }^{55}$ Namely, the Communist Party taps high tax-paying SOE-managers for promotion and other benefits more frequently. In their summary of the literature, Jansky and Prats find that ties to a tax haven often provide enough of a predictor of tax avoidance/evasion. ${ }^{56}$ They do not have data for China. But if countries like India serve as a possible comparator, firms with linkages to tax havens pay 30\% less tax than companies without these links. Fisman et al., specifically for their part of this story, find that traders use "offshore" Hong Kong as a way to avoid paying Chinese taxes and tariffs. ${ }^{57}$ Thus, Hong Kong serves as a key channel for spiriting away evaded tax proceeds.

What effect does corporate governance have on reducing such tax evasion? Figure 14 shows the effects of putting more financial experts and independent directors on corporate boards in general. ${ }^{58}$ If these results apply to China in the same way as the US, corporate governance reforms like these probably encourage tax paying behaviour for companies not already heavily engaged in tax evasion. Yet, for those companies which evade large shares of tax, more comprehensive corporate governance reform seems to correspond to more tax cheating. Desai

\footnotetext{
53 See Liu, Qiao and Geng Xiao, Look Who Are Disguising Profits: An Application to Chinese Industrial Firms, 2004, available online.

${ }^{54}$ Id. at Figure 1.

${ }^{55}$ See Zhang, Huai, How Does State Ownership Affect Tax Avoidance? Evidence from China, Singapore Management University School of Accountancy Working Paper \#2012/13-18, 2013, available online.

${ }^{56}$ See Jansky, Petr and Alex Prats, Multinational Corporations and the Profit-Shifting Lure of Tax Havens, Christian Aid Occasional Paper Number 9, 2013, available online.

${ }^{57}$ See Fisman, Raymond, Peter Moustakerski, and Shang-Jin Wei, Outsourcing Tariff Evasion: A New Explanation for Entrepot Trade, The Review of Economics and Statistics 90(3), 2008, available online.

${ }^{58}$ See Armstrong, Christopher, Jennifer Blouin Alan Jagolinzer, and David Larcker, Corporate Governance, Incentives, and Tax Avoidance, Journal of Accounting and Economics 60, 2015, available online.
} 
and Dharmapala find that increases in tax avoidance leads to increases in Tobin's $q$ of around $2.5 \%$ only with better governed firms. ${ }^{59} \mathrm{Kim}$ and co-authors find that stock prices become more resilient against crashes by around 0.2 as tax avoidance decreases (as companies pay more taxes). ${ }^{60}$ Figure 15 shows the counter-intuitive relationship between corporate governance and tax evasion found in much of the literature. Better corporate governance of course leads to less tax evasion. Yet, these data also show that corporate governance can - for badly governed companies - contribute to tax evasion and other criminal behaviour. Thus, simply reforming Chinese corporate governance as it is may make such governance worse rather than better.

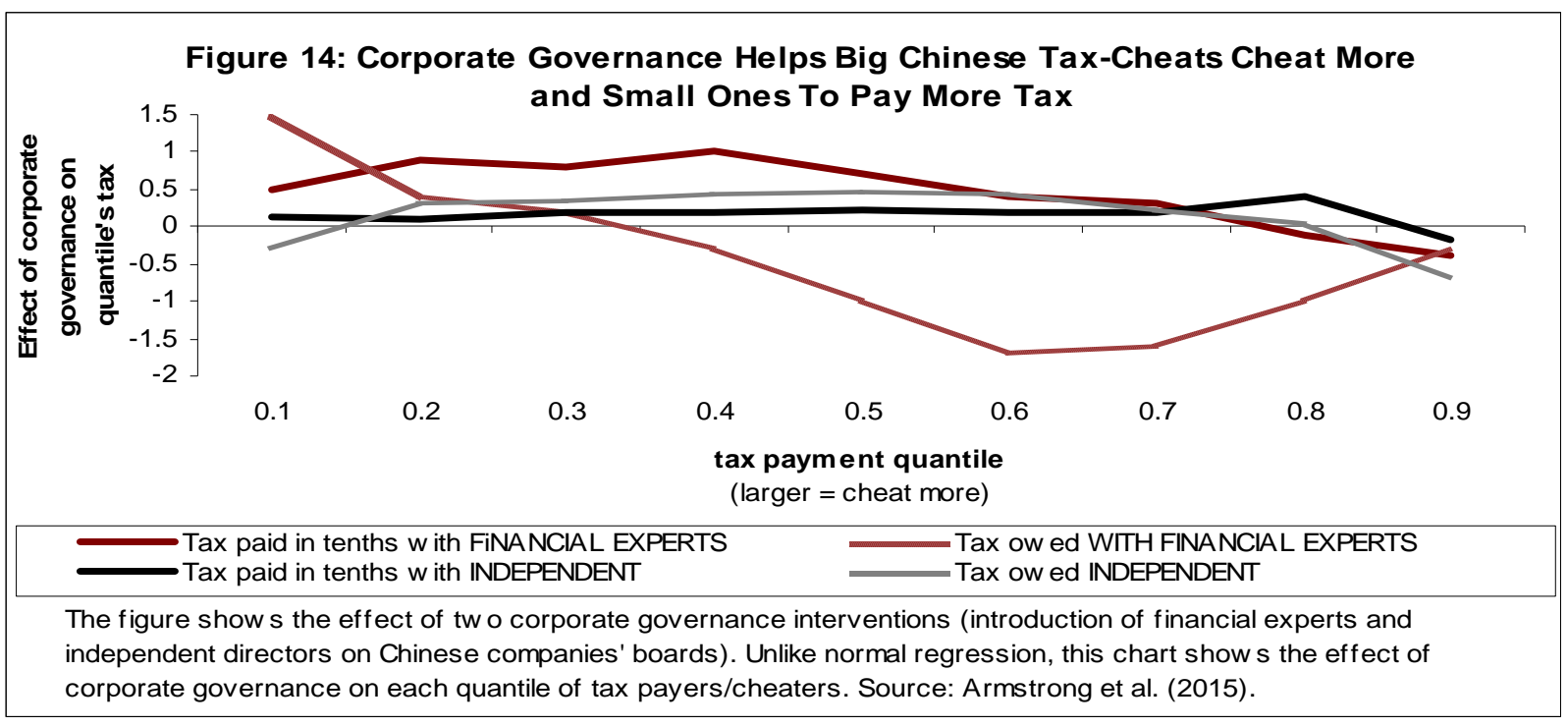

\section{Figure 15: Comorate Govemance Determines the Level of Tax Benefits and the Distribution between Selfish versus Business Ends}

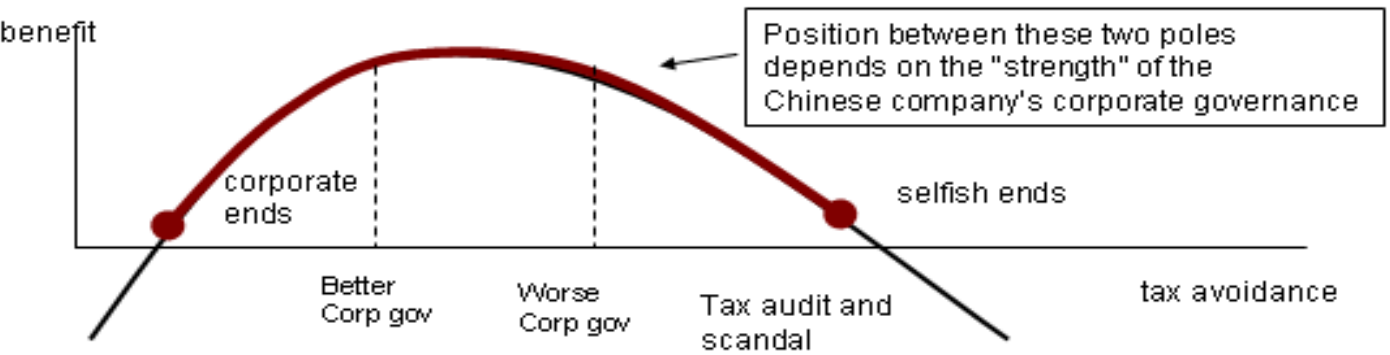

The figure shows a simplified representation of the relevant literature looking at the relationship between tax evasion and company "benefits" (net of corporate-governance-related spending and as defined in each stucky). Corporate governance reforms sexk to obtain benefits by curtailing tax avoidance. Such reform in very misgoverned companies would likely contribute to further tax avoidance (and other forms of corporate mal-governance).

Sources: See text for souroes cited.

\footnotetext{
${ }^{59}$ See Desai, Mihir and Dhammika Dharmapala, Corporate Tax Avoidance and Firm Value, NBER Working Paper Series Working Paper 11241, 2005, available online.

${ }^{60}$ See Kim, Jeong-Bon, Ying-Hua Li, and Lian-Dong Zhang, Corporate Tax Avoidance and Stock Price Crash Risk: Firm-Level Analysis, Journal of Financial Economics, 2010, available online.
} 


\section{What Do the Panama Papers Data Show About China's Corporate Governance?}

The Mossack Fonseca and Open Leaks data provide some indication about the relationship between corporate governance and the use of offshore structures in Hong Kong and the Mainland. Figure 16 shows the percent change in offshore account openings as corporate governance scores for the jurisdiction improve. ${ }^{61}$ Mainland account openings increased at a time when corporate governance had improved - suggesting that perhaps other factors (besides corporate governance) contributed to these account openings. Yet, Hong Kong based intermediaries opened fewer offshore accounts during the same time period. Figure 17 indeed shows that Hong Kong offshore account openings decreased during the time when the number of Chinese accounts rose. Figure 18 shows that other jurisdictions had reduced their offshore incorporations during a time of relatively stable corporate governance. Thus, Mainland offshore incorporations thus might have made up for the decreases in other jurisdictions.
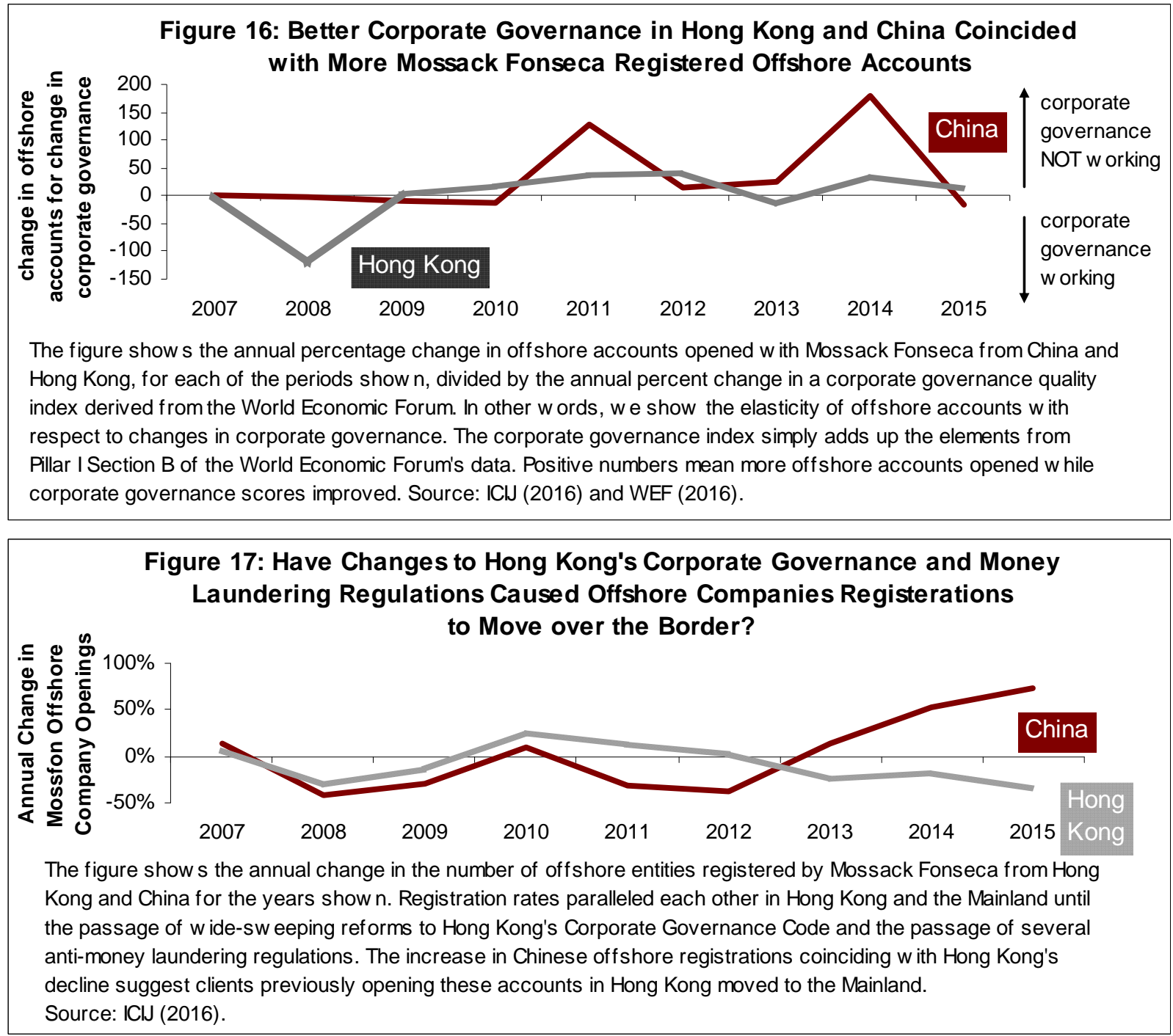

${ }^{61}$ World Economic Forum, Competitiveness Rankings 2015-2016, 2016, available online. 


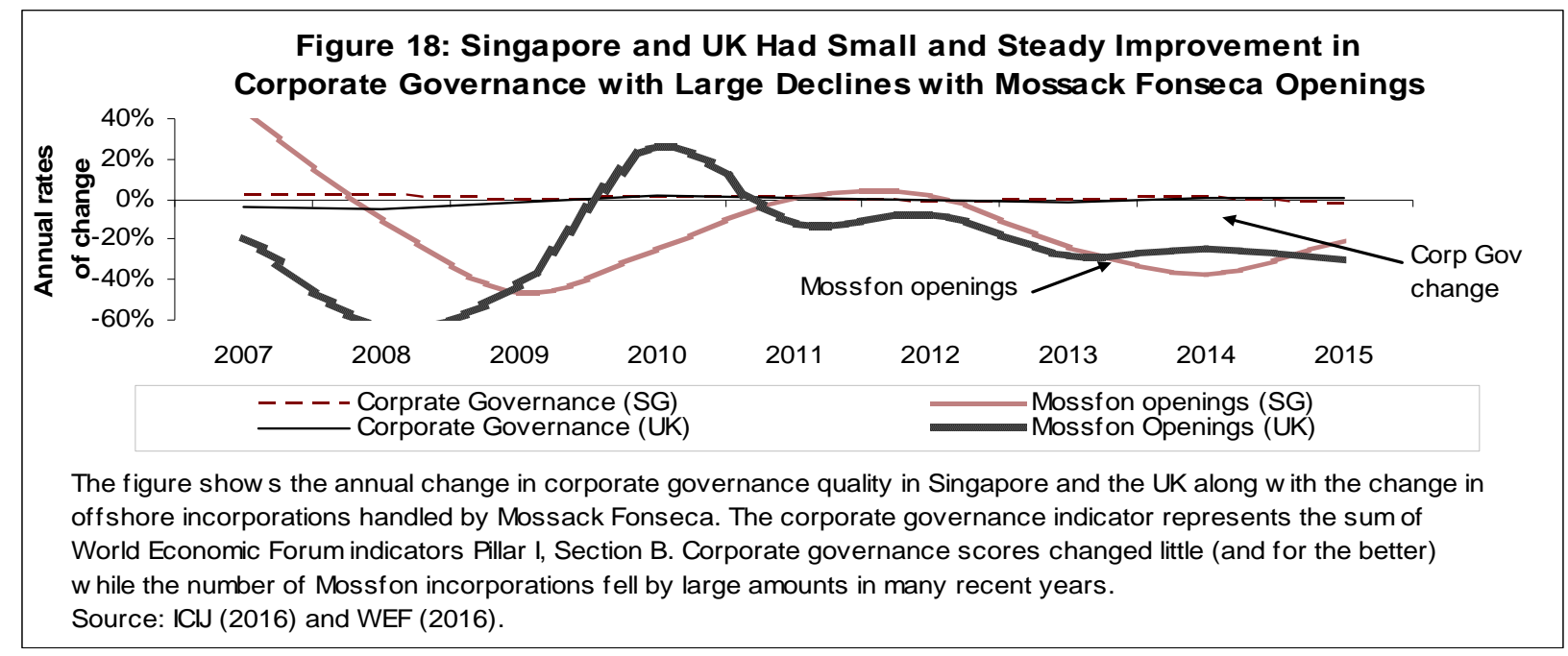

A bit more analysis shows other trends and patterns in the interactions between corporate governance and offshore incorporations in Hong Kong and the Mainland. Figure 19 shows the relationship between the rate of change of improvements in the Mainland's corporate governance and its levels of offshore incorporations. Once Chinese companies go down the road of improving their corporate governance, they will likely continue to do so. Such improvements furthermore correlate with less demand for offshore incorporations. The only "viable" corporate governance programmes rate a 34.5 or higher. At such a take-off level (as we label in the figure), corporate governance leads to sustainable decreases in offshore incorporations and selfimproving corporate governance. Figure 20 shows similar data for Hong Kong - with different results. Hong Kong's stable corporate governance rates hover at around 48.2 (or 14 points higher than their Mainland counterparts). Interesting, better corporate governance in Hong Kong seems to correlate with more demand for offshore incorporations. Yet, Hong Kong companies' demand for offshore incorporations increases most with the relatively rapid deterioration of their corporate governance ratings from high levels of corporate governance to lower levels.

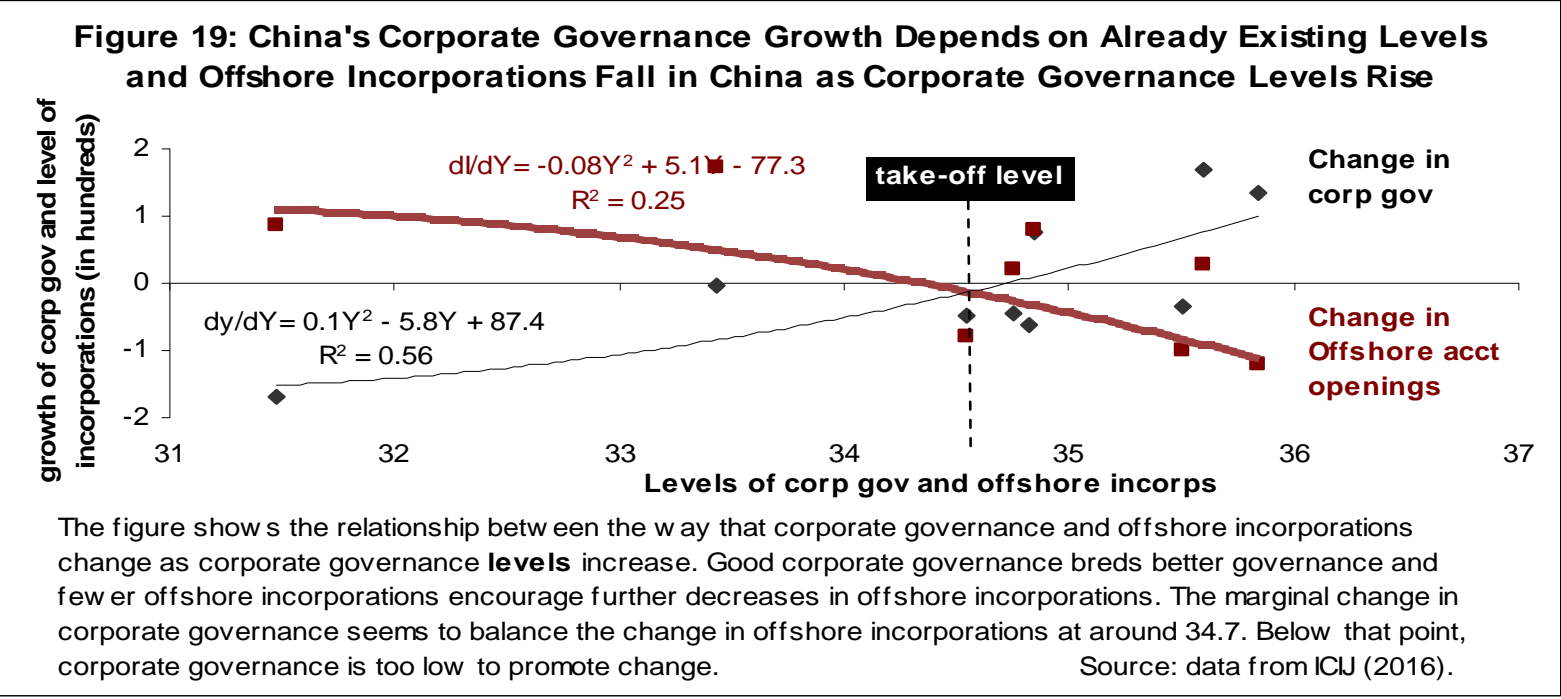


Figure 20: Hong Kong's Changes in Corporate Governance and Offshore Incorporations Stable For Bad as Well as Good Levels of Corporate Governance

(in other words, exhibit double equilibria)

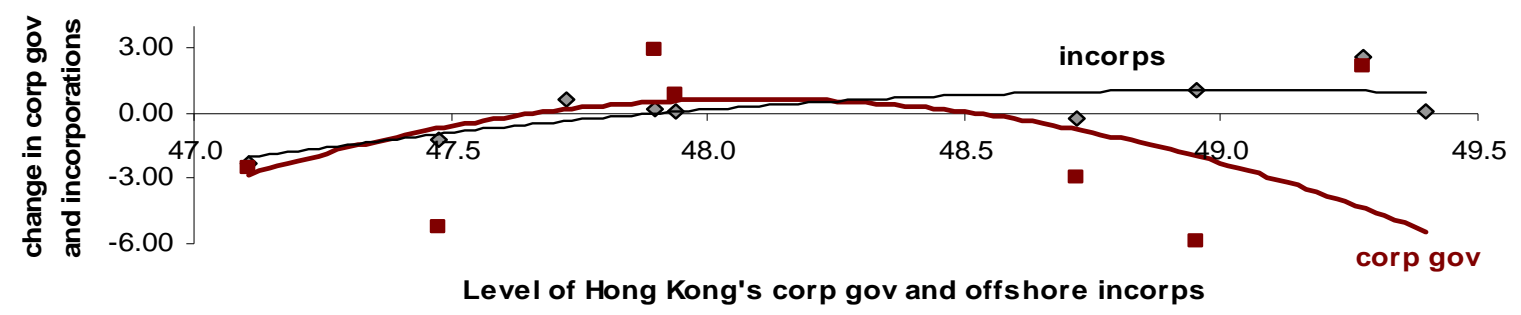

The figure show s the extent to w hich levels of corporate governance influence changes in Hong Kong's corporate governance and offshore incorporations. Corporate governance should remain stable-ish at levels of 47.5 and 48.5 . Yet, better corporate governance seems to encourage more offshore incorporations. The most rapidly falling corporate governance unsurprisingly correlates $w$ ith the fastest grow th in offshore incorporations.

Source: ICIJ (2016).

What about the relationship between Hong Kong and the Mainland? What proof exists that Hong Kong somehow contributes (or not) to the Mainland's corporate governance and offshore incorporation practices? Figure 21 shows some initial evidence for such a relationship. Unsurprisingly, bad corporate governance in Hong Kong correlates with bad governance on the Mainland - and visa-versa. Yet, a range of Hong Kong "bad boys" exists for companies scoring between 47.5 to 48.75 . When Hong Kong companies have corporate governance in this range, corporate governance on the Mainland falls the fastest. Moreover, Mainland companies can expect a deterioration in their corporate governance to the low value of the range (namely 47.5), as they deal with relatively unreliable partners? Differences-in-differences analysis shows a 3 point improvement in the Hong Kong's corporate governance during the time of Corporate Governance Listing Rules, showing that such changes do affect corporate governance.

Figure 21: China's Corporate Governance Reform (Change) Depends on the Quality of Corporate Governance in Hong Kong

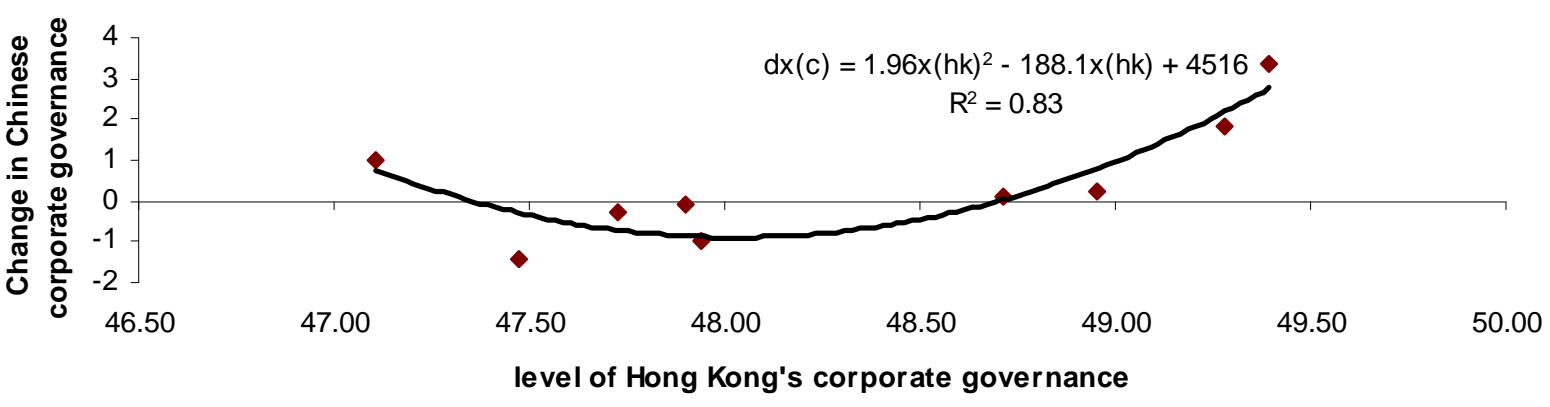

The figure show s the way that Mainland corporate governance changed over time as the level of Hong Kong's corporate governance improved in the post-Listing Rules-reform era. More advanced time series estimation validates this relationship (and the line of best fit anyw ay explains $83 \%$ of the variation in the data). One way of improving corporate governance on the Mainland thus consists of improving it in Hong Kong. Middling levels of Hong Kong's corporate governance seem w orst for Chinese governance - as low and high levels push Chinese companies to do better.

Source: data from ICIJ (2016). 
Network analysis of the Panama Papers database points most strongly to the way that Hong Kong contributes to China's corporate governance travails. Figure 22 shows the way that offshore entities incorporated by Mossack Fonseca (or other agents in the ICIJ database) link to the jurisdictions shown in the figure. If Chinese companies simply used Hong Kong based incorporation agents to spirit funds offshore, we would expect strong links mainly between these two jurisdictions. We see though, that both jurisdictions have many jurisdictions in common with many BVI entities starting in Hong Kong and ending on the Mainland (for example). Some jurisdictions relate primarily to one jurisdiction or the other (like the Cook Islands and Hong Kong. Yet, Hong Kong and the Mainland have more links with these other jurisdictions than either random luck or other jurisdictions' experiences would suggest. ${ }^{62}$ Overlapping decisions to use particular jurisdictions at particular times suggest that Hong Kong and China form poles in a broader network of offshore corporate relations, which likely "layer" across numerous jurisdictions. ${ }^{63}$

\section{Figure 22: Hong Kong and China Share Far More Business With the Same Jurisdictions} than Coincidence Can Explain

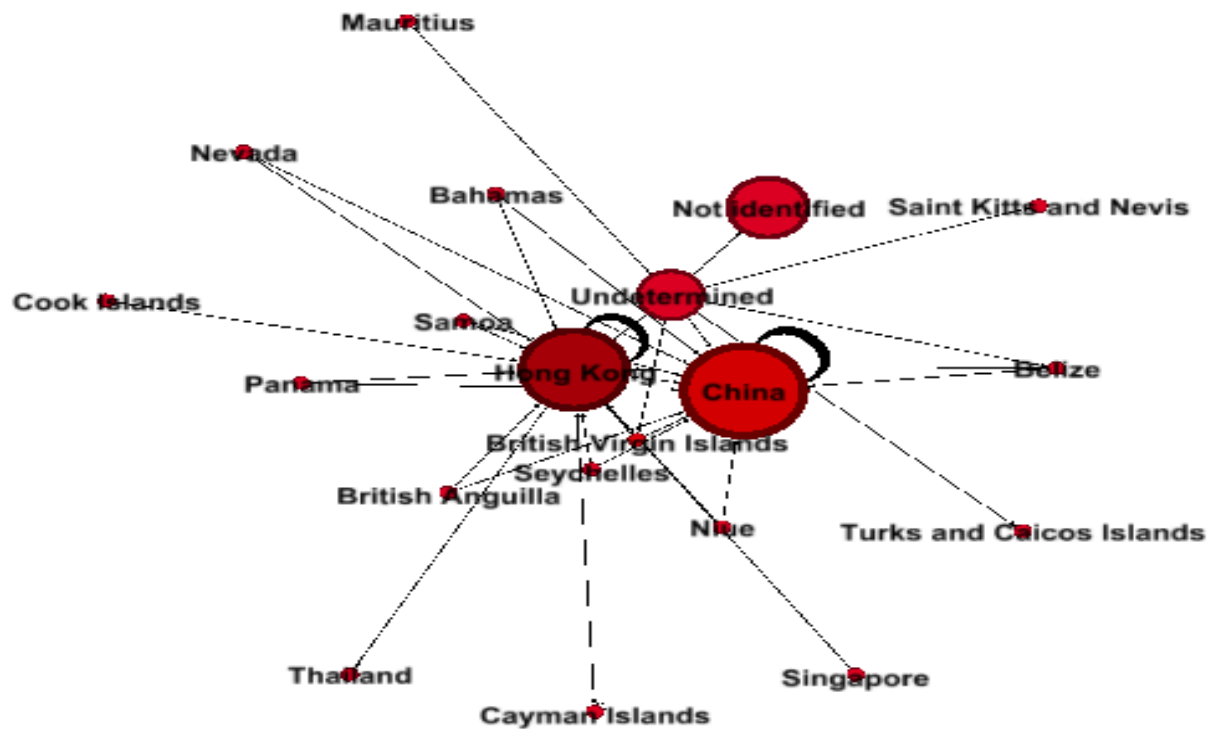

The figure shows the links between the offshore entities in the jurisdictions shown for Hong Kong and China. We downloaded the ICIJ data for Hong Kong and China, ran them through network analysis software, and looks for patterns. The links between China-Third Party- Hong Kong occur far more likely than random variation would allow (and more than we see in other pairs of jurisdictions like US/UK or Singapore/Malaysia etc.). The number of 'undetermined' and 'non-identified' jurisdictions (even in the Mossack Fonseca data!) seem disconcerting. Source: based on data from the ICIJ (2016).

\footnotetext{
${ }^{62}$ We test this by looking at the probability distributions that govern Singapore's, Taiwan's, Thailand's and the UK's links with other offshore jurisdictions (and we explain why we chose these comparator jurisdictions later in this paper). We also look at a random probability distribution. We find that "attraction" between China and Hong Kong explains the increased incidence of linking with these other jurisdictions. Jurisdictions which Hong Kong clients use tend to link to the Mainland more often (and visa versa).

${ }^{63}$ To keep our paper from being too technical, we do not report the correlations between the extent to which Hong Kong and Mainland firms use particular jurisdictions in particular years. As we illustrated informally above, jurisdictions like Niue attracted waves of incorporations which demanders of offshore corporate vehicles might have concurrently sought.
} 
Other evidence supports the hypothesis that Hong Kong's corporate governance influences corporate governance on the Mainland. Figure 23 shows the extent to which changes in corporate governance pass through to offshore incorporations - both at home and in the other jurisdiction. Changes in corporate governance (as measured by the World Economic Forum's corporate governance indicators) had a much higher correlation (impact?) on offshore incorporations in China - about 5 times higher than in Hong Kong. Yet, Chinese firms seem to adjust their corporate governance more than proportionately for changes in (at the same time as?) Hong Kong's corporate governance. A 1\% change in Hong Kong's corporate governance (or offshore incorporations) results in a $1.3 \%$ change in Mainland corporate governance and/or offshore incorporations. Thus, Hong Kong's corporate governance might have a disproportionate large impact on the Mainland's corporate governance.

Figure 23: Comprehensive Analysis of Corporate Governance, Offshore Incorporations and the Interaction between Hong Kong and the Mainland

\begin{tabular}{|c|c|c|c|c|c|c|c|c|c|c|}
\hline $\begin{array}{c}\text { Jurisdiction } \\
1 \\
\text { (X) }\end{array}$ & $\begin{array}{c}\text { CG/ } \\
\text { PP }\end{array}$ & & $\begin{array}{c}\text { Jurisdiction } \\
2 \\
(\mathbf{Y})\end{array}$ & $\begin{array}{l}\text { CG/ } \\
\text { PP }\end{array}$ & $\begin{array}{l}\text { Effect } \\
(Y / X)\end{array}$ & $\begin{array}{c}\mathbf{R} \\
\text { squared }\end{array}$ & $\begin{array}{c}\text { Percent } \\
\text { effect in } \\
\text { year } 2\end{array}$ & $\begin{array}{l}\text { Percent } \\
\text { effect in } \\
\text { year } 2.5\end{array}$ & 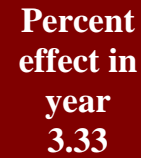 & $\begin{array}{c}\text { Percent } \\
\text { effect in } \\
\text { year } 5\end{array}$ \\
\hline China & CG & & China & $\mathrm{PP}$ & $1 \%$ & $61 \%$ & $34 \%$ & $9 \%$ & $17 \%$ & $61 \%$ \\
\hline Hong Kong & CG & $--->$ & Hong Kong & PP & $0.02 \%$ & $70 \%$ & $0 \%$ & $65 \%$ & $73 \%$ & $70 \%$ \\
\hline Hong Kong & CG & $--->$ & China & CG & $1.3 \%$ & $70 \%$ & $0 \%$ & $70 \%$ & $36 \%$ & $52 \%$ \\
\hline Hong Kong & CG & $--->$ & China & PP & $1.3 \%$ & $33 \%$ & $7 \%$ & $33 \%$ & $2 \%$ & $4 \%$ \\
\hline
\end{tabular}

The figure shows the way that changes in the wave-like patterns in Hong Kong (variable $x$ ) in the factors shown above correlate with the wave-like patterns on the Mainland (denoted as $y$ ). CG refers to the corporate governance proxy for each jurisdiction and PP represents the Panama Papers' recorded number of offshore incorporations. Readers familiar with statistics will recognise these as the results of bi-variate Fourier analysis. We take the “coherency” between these variables as the R2 and "gain” as the coefficient of change. The "percent effect” shown in the black boxes on the far right do not add up. They represent the extent to an "impulse" in that time frame. Readers unfamiliar with Fourier analysis only need to read the data like a normal regression - keeping in mind that we used more sensitive, appropriate methods for these time series data.

What is the effect of the low corporate governance and higher offshore incorporations that can lead to tax evasion - and thus impact on stock market values? Figure 24 informally looks at the way that share prices reacted when the Panama Papers publicly identified Chinese managers/ investors linked to these companies. The figure does not control for general market factors, industry or firm specific effects. These factors would likely have a much smaller impact on a two month study (such as ours), rather than many of the usual multi-year studies. Yet, these results fail to show any clear pattern. Some companies' share prices rose before and after the disclosures which might have affected them. Others share prices fell before and/or after the disclosures. Investors obviously did not see evidence of offshore incorporation as very strong evidence of self-dealing and other problems at these companies. At first glance then, poor corporate governance and wide-spread offshore incorporation seems to pose little threat to Hong Kong's and the Mainland's market valuations. 


\section{Figure 24: Bowtie Share Price Response Suggests Little Real Chinese Corporate Reaction to Panama Papers Revelations}

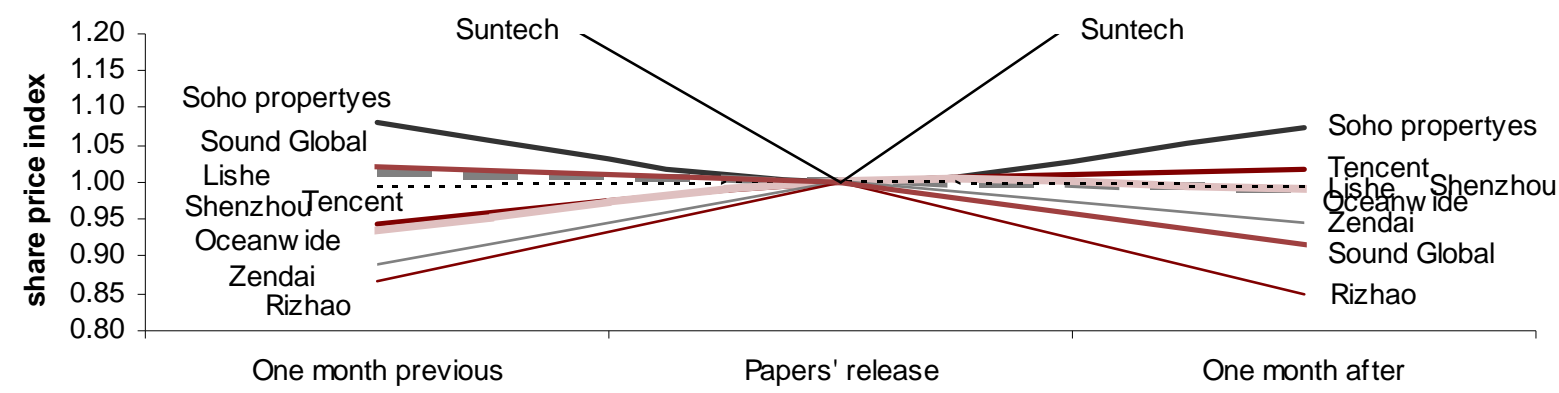

The figure show s the share price index for companies w hose senior management and/or investors had been identified in the Panama Papers or the Offshore Leaks. Some companies' share price did better, some w orse (before removing the effects of firm-specific and market factors). Nothing about these data suggest any pattern w orth investigating further. As described in detail in our paper, some companies probably did better from offshore incorporations and some w orse. Source: based on data from Bloomberg (2016) w ith companies' identities provided by the ICIJ (2016).

Yet, more rigorous evidence supports a clearer link between tax evasion on the Mainland and share price movements. Zhang Chen and co-authors find that tax evasion/avoidance leads to declining market values, unless the corporate board is skilled enough to use the extra money to increase growth opportunities. ${ }^{64} \mathrm{Xu}$-Dong Chen and those co-authors find that tax evasion ends up decreasing firm value --- despite its positive effects on profits and growth. ${ }^{65}$ If tax avoidance helps increase market values by 13\%, then losses from self-serving and worries about lack of transparency reduce market values by around $20 \% .{ }^{66}$ They see the existing regulations as a mechanism for creating rents - which businessmen extract for reasons too complex to discuss here. Increasing firm transparency and revisions to the tax rules which create tax-evasion-related rents, thus can decrease the value lost from tax evasion.

Most importantly, what do the evidence saw about policymakers' ability to change corporate governance on the Mainland? If corporate governance responds to outside influences, policymakers might change such governance practices more than in companies choosing their corporate governance practices by institutional inertia. Figure 25 shows the weight of institutional inertia (or history) versus the effects of external shocks and innovations in leading to changes in corporate governance and/or offshore incorporations. Both corporate governance and offshore incorporations appear very heavily influenced by external factors - much more than past actions on corporate governance/offshore incorporations. In contrast, comparator countries like Taiwan, Thailand and the UK seems to have corporate governance influenced more by external events and offshore incorporations influenced by lethargy or pre-existing trends and relationships. Thus, the high reliance on China's corporate governance on external pushes makes internal reform unlikely.

\footnotetext{
${ }^{64}$ We use the author's first name as a different Chen headed up the two papers we cite in succession. See Chen, Zhang, Cheong-Kee Cheok, and Rajah Rasiah, Corporate Tax Avoidance and Performance: Evidence from China’s Listed Companies, Institutions and Economies 8(3), 2016, available online.

${ }^{65}$ See Chen, Xu-Dong, Na Hu , Xue Wang , and Xiao-Fei Tang , Tax Avoidance and Firm Value: Evidence from China, Nankai Business Review International 5(1), 2014, available online.

${ }^{66}$ Id at table 8 .
} 


\section{Figure 25: What Causes Changes in Corporate Governance and Offshore Incorporations?}

\begin{tabular}{|c|c|c|c|}
\hline Jurisdiction & Explanation & $\begin{array}{l}\text { History } \\
\text { (p) }\end{array}$ & $\begin{array}{l}\text { External } \\
\text { shocks } \\
\text { (q) }\end{array}$ \\
\hline \multicolumn{4}{|l|}{ Corp Gov } \\
\hline China & $\begin{array}{l}\text { Corporate governance relies on past reforms and worses with external } \\
\text { events. }\end{array}$ & 0.76 & -0.98 \\
\hline Hong Kong & No dependence on past reforms and improves with external events & 0 & 0.98 \\
\hline Singapore & Worsens with external events & 0 & -0.98 \\
\hline Taiwan & Nothing effects its corporate governance & 0 & 0 \\
\hline Thailand & Improves with external events & 0 & 0.98 \\
\hline UK & Reflects most past reforms & 0.8 & 0 \\
\hline \multicolumn{4}{|c|}{ Panama Incorporations } \\
\hline China & Offshore incorporations fall on external events & 0 & -0.98 \\
\hline Hong Kong & Offshore incorporations depend mostly on history/past experience & 0.85 & 0 \\
\hline Singapore & ditto & 0.78 & 0 \\
\hline Taiwan & ditto & 0.84 & 0 \\
\hline Thailand & $\begin{array}{l}\text { Offshore incorporations fall on external events } \\
\text { Offshore incorporations depend mostly on history/past experience and offshore }\end{array}$ & 0 & -0.98 \\
\hline UK & incorporations fall on external events & 0.83 & -0.99 \\
\hline \multicolumn{4}{|l|}{ Effects * } \\
\hline China & Effect of corporate governance on offshore incorporations & $1 \%$ & $61 \%$ \\
\hline Hong Kong & $\begin{array}{l}\text { Effect of corporate governance on offshore incorporations } \\
\text { Correlation between a change in Hong Kong's corporate governance relative to }\end{array}$ & $0.02 \%$ & $70 \%$ \\
\hline $\mathrm{CN} / \mathrm{HK}$ & China's. & $1.26 \%$ & $16 \%$ \\
\hline $\mathrm{HK} / \mathrm{CN}$ & Correlation between a change in China's offshore incorporations to Hong Kong's & $1.34 \%$ & $32 \%$ \\
\hline
\end{tabular}

* Other countries exhibited no significant effects.

The figure shows the effects of ARIMA (or auto-regressive, integrated moving average) analysis. Such analysis hopes to show the way the past (as reflected in auto-regressive values) affects a variable relative to outside influences (the moving average part). The last part of the figure shows "effects" as simple correlations

\section{Why China's Reform Can't Come from the Inside}

Many authors implicitly argue that Chinese companies, if left to their own devices, will not reform their own corporate governance. Authors like Wang have outlined in detail why Chinese companies do not want to improve corporate governance. ${ }^{67} \mathrm{He}$ - and authors like him - outline the ways that Chinese companies use profits and funds raised from investors to implement Communist Party and government policies, rather than maximise profits. State-owned enterprises particularly reflect this problem - where the Party controls hiring and other decisions far removed from the use of funds. Recent cases of CEO swapping at China Telecom and China Unicom as well as at CNOOC and PetroChina illustrate the Party's role in SOEs most clearly. ${ }^{68}$ For Wang (Zhao-Feng and not Jiang-Yu cited above), as well as a large number of corporate governance experts on the Mainland, their concept of improving corporate governance only consists of figuring out how to improve SOEs' abilities to cheaply and effectively fulfil their Party-mandated

\footnotetext{
${ }^{67}$ See Wang, Jiang-Yu, The Political Logic of Corporate Governance in China's State-Owned Enterprises, Cornell International Law Journal 47(3), available online.

${ }^{68}$ See Kawase, Kenji, Corporate governance has a distinctly different meaning in China, Nikkei Asian Review July, 2016, available online.
} 
social objectives. ${ }^{69}$ Figure 26 shows the way that Chinese SOEs in particular have kept less performing corporate governance institutions (like Communist Party firm secretaries working at the company) alive while constraining shareholder returns. ${ }^{70}$ As the authors show, Mainland firms without party secretaries (as senior level persons who influence managers based on Party priorities), tend to do better than those that have them. Their Tobin's $q$ values, sales, employment, even valuations-to-shareholder equity vales exceed those of their party-secretary-line-totting brethren. In brief, such political control has led to reduced share price appreciation. ${ }^{71}$ The Chinese government thus has very weak incentives to improve corporate governance.

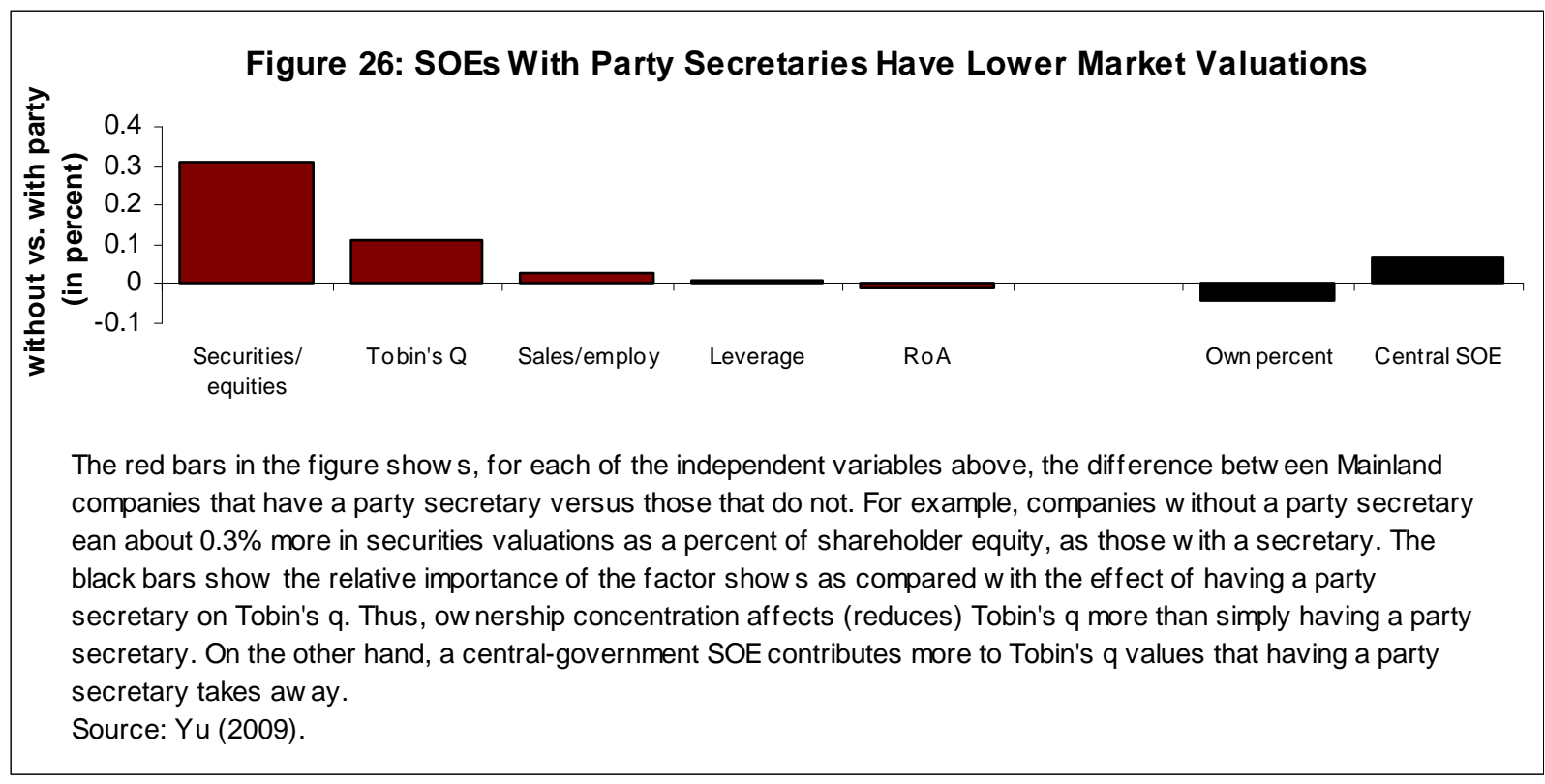

Does lack of interest by the central government, or by boards themselves, explain why Chinese companies will not - if left to their own devices - adopt better corporate governance practices? Chen et al., for example, find that - using data on corporate fraud committed by Chinese firms that poor corporate governance practices can increase the probability of fraud. ${ }^{72}$ Specifically, companies with large proportions of inside directors have an $18 \%$ probability of prosecution for

\footnotetext{
${ }^{69}$ He cites an old SOE law which requires Party representatives in the SOE to support the objectives of the Party and state. In our own reading of the revised Law (at least the one talking about state-owned assets), these requirements disappeared. Yet, SOEs are not forbidden from considering these factors either. Gu argues that the long hand of political influence continues to work in China’s SOEs. See Zhao-Feng Wang, Corporate Governance under State Control: The Chinese Experience, Theoretical Inquiries in Law 13(2), 2012, available online. See also Gu, Bin, Corporate governance pivotal part of State-owned enterprise reforms, Global Times, 2013, available online. See also Law of the People's Republic of China on the State-Owned Assets of Enterprises, Presidential Order 5, 2009, available online.

${ }^{70}$ See Yu, Wei, Party Control in China’s Listed Firms, Doctoral dissertation, Chinese University of Hong Kong, available online.

${ }^{71}$ The conclusion seems relatively robust and stable across time. For an earlier study showing the same effects, see Chang, Eric and Sonia Wong, Corporate Governance, Political Interference, and Corporate Performance of China's Listed Companies, 2002, available online.

${ }^{72}$ Chen, Gong-meng, Michael Firth, Daniel Gao, and Oliver Rui, Ownership structure, corporate governance, and fraud: Evidence from China, Journal of Corporate Finance 12(3), 2006, available online.
} 
fraud for each inside director added. ${ }^{73}$ Each year the chairman stays reduces the probability of a fraud prosecution by $42 \%$. Every extra board meeting decreases the probability of discovering fraud by $52 \%$. The effectiveness of Chinese supervisory boards provides another excellent example. Jia and co-authors' econometric analysis shows that supervisory boards engage more actively in company affairs when their listed companies face investigation by securities regulators (the exchange or The China Security Regulatory Commission). ${ }^{74}$ Larger supervisory boards typically attract more severe sanctions, presumably because they should have known better. In line with such stepped-up punishment, supervisory board meetings generally increase when the company faces such an investigation. ${ }^{75}$ In another example of Chinese institutions stymieing reforms, Wang and Campbell show econometrically that Chinese firms implementing International Financial Reporting Standards (IFRS) have the same amount of earnings manipulation as non-IFES firms. ${ }^{76}$ They similarly find that earnings manipulation decreases with more independent directors on the board of private (non-SOE) firms. Yu and Razaee similarly find that good governance makes the transition to IFES standards easier. ${ }^{77}$ Yet, Mainland firms still do not adopt the better corporate governance practices that makes IFES and other reforms easier. Even if the Mainland government wanted to push better corporate governance, entrenched incentives prevent such reform.

Worse still, institutions on the Mainland could nullify the beneficial impacts of corporate governance policies which have typically helped improve shareholder value in Hong Kong and the West. Lai has relatively recently shown how rules encouraging the appointment of independent directors on Chinese boards led to more earnings management as their corporate governance rules became institutionalized. ${ }^{78}$ Lai places the blame for the failure of these independent directors' inability to restrain earnings management specifically on regulation designed seemingly to thwart, rather than encourage, independent directors' independence. Ting and co-authors similarly find that audit committees tend to correspond with more earnings management, when combined with ownership concentration and the presence of government

\footnotetext{
${ }^{73}$ We converted the original data (regression coefficients from probit regression into probabilities).

${ }^{74}$ Jia, Chun-Xin, Shu-Jun Ding, Yuan-Shun Li, and Zhen-Yu Wu, Fraud, Enforcement Action, and the Role of Corporate Governance: Evidence from China, Journal of Business Ethics 90(4), 2009, available online.

${ }^{75}$ Readers unfamiliar with Chinese boards should not confuse supervisory boards and the management board (or board of directors). In theory, supervisory boards should mostly look after (supervise) corporate governance matters. Yet, as we have previously cited, the board of directors plays a much bigger role in pushing good corporate governance. Authors like Cho and Rui demonstrate a positive correlation between firm performance and the proportion of independent board of directors members and the frequency of supervisory committee meetings. They also show a positive correlation between earnings informativeness and the proportions of independent directors on the company board and supervisory committee. See Cho, Stella, and Oliver Rui, Exploring the Effects of China's Two-tier Board System and Ownership Structure on Firm Performance and Earnings Informativeness, Asia-Pacific Journal of Accounting \& Economics 16(1), 2012, available online.

${ }^{76}$ Wang, Ying and Michael Campbell, Corporate governance, earnings management, and IFRS: Empirical evidence from Chinese domestically listed companies, Advances in Accounting 28(1), 2012, available online.

${ }^{77} \mathrm{Yu}$, Chen and Zabihollah Rezaee, The role of corporate governance in convergence with IFRS: evidence from China", International Journal of Accounting \& Information Management 20(2), 2012, available online.

${ }^{78}$ Lai, Liona, Monitoring of earnings management by independent directors and the impact of regulation: evidence from the People's Republic of China, International Journal of Accounting, Auditing and Performance Evaluation 7(1/2), 2011, available online.
} 


\section{officials on audit committees. ${ }^{79}$ In other words, simply adopting Western/Hong Kong style corporate rules on the Mainland will not work without some form of deus ex machina able to identify and solve problems outside the existing system.}

Changing such institutions would require far more than simply importing rules from Hong Kong. Miao shows the need, using several case studies, for a complete overhaul of China's public governance for corporate governance reform to succeed. ${ }^{80}$ Tomasic argues that Chinese law does not recognise many of the legal principles - and therefore provisions -- allowing for Westernstyle corporate governance practices in the Middle Kingdom. ${ }^{81}$ Authors like Bin et al. find that changes - like the famous 2005 split-share structure reform -- had no impact on the way that corporate governance affects Chinese firm performance. In other words, corporate governance remains unmoved by, and indifferent to, different policies. ${ }^{82}$ Ma and Khanna find that independent directors' dissent does not have the same returns as in the West. ${ }^{83}$ Tan and Wong, in their overview piece, lament the futility of trying to implement corporate governance reforms in Mainland companies. ${ }^{84}$ The only out, for them, consists of creating a Temasek-style method of corporate governance in SOEs reformed as state-asset management companies. In other words, force foreign management practices and rules on to Chinese managers. The authors had such a poetically beautiful description of the current problems which prevent reform-from-the-inside, we uncharacteristically reprint it in its full:

Having seen the politico-cultural traditions of China, one can easily understand why the independent director and supervisory board system does not work in China at all. The majority of supervisory board members are cadres who occupy a secure and well-defined position within the Party hierarchy and ranks of officialdom. He is constrained by and also loathes to upset the network of relationships existing within the listed SOE and between the SOE and its department-in-charge. Thus he sees himself as the government's apparatus to supervise the directors for violations of law or any acts that threatened the political interests of the Party. His loyalty is to his superior and more distantly the Chinese Communist Party as personified by Deng and his factions of successors such as Jiang Zemin and Hu Jintao. He belongs unquestionably to the side of authority. He does not understand that in modern China the state's interest has become pluralistic for he grew up under the all-pervading influence of the powerful monolithic bureaucracy. Hence, he is ineffectual as a supervisory board member for the simple reason that he has not been taught and do [sic] not understand that there are other interests of the state to be protected besides its political and power interests. Put simply, he does not understand the Western

\footnotetext{
${ }^{79}$ See Lin, Teng, Marion Hutchinson, and Majella Percy, The Role of the Audit Committee and Institutional Investors in Constraining Earnings Management : Evidence from Chinese Firms, Proceedings of Accounting and Finance Association of Australia and New Zealand Annual Conference, 2009, available online.

${ }^{80}$ See Miao, Yin-Zhi, Overseas Listing and State-Owned-Enterprise Governance in China: The Role of the State, 2012, available online.

${ }^{81}$ See Tomasic, Roman, Corporate Governance in Chinese Companies Going Global, The Chinese Journal of Comparative Law 2(1), 2014, available online.

${ }^{82}$ See Leo Bin, Leo, Dar-Hsin Chen and Kun-Yan Chan, Chinese Corporate Profitability Performance Following The Split-Share Structure Reform, Journal of Finance and Accountancy 19(1), 2015, available online.

${ }^{83}$ See Ma, Juan and Tarun Khanna, Independent Directors’ Dissent on Boards: Evidence from Listed Companies in China, Harvard Business School Working Paper 13-089, 2013, available online.

${ }^{84}$ See Tan, Lay-Hong and Yu-Wang Jiang, Modelling an Effective Corporate Governance System for China's Listed State-Owned Enterprises: Issues and Challenges in a Transitional Economy, Journal of Corporate Law Studies, August 2007, available online.
} 
dynamics of checks and balances between the supervisory board and management board

in their bid to protect the economic interests of the shareholder as owners of capital.

Tan \& Wang (2007)

\section{Listing in Hong Kong Simply Isn't Good Enough}

What about simply listing on a foreign exchange? Should/Can the Mainland import (or bond) foreign corporate governance to their domestic operations? Guo and co-authors show that a foreign listing - specifically a Hong Kong listing - can increase the market value of Mainland companies by literally hundreds of percent. ${ }^{85}$ Other data from authors like Klautzer (2013), show that openness encourages the corporate governance reform that eventually impacts on profits and market valuations. ${ }^{86}$ Zhou and co-authors show that a foreign listing in Hong Kong statistically significantly correlates with increases in Mainland firms' returns on assets, board control, and board characteristics (themselves composite indices consisting of the attributes we have already described). ${ }^{87}$

Yet, some types of improvements in corporate governance may increase market valuations more than others. Figure 27 shows the way that Chinese market valuations have changed in response to the valuation of their American Depository Receipts (ADRs) ${ }^{88}$ As the authors show, listing in the US - with its stronger corporate governance standards - might improve valuations more than on the Asian bourses (like Hong Kong and Taiwan). ${ }^{89}$ Yet, some improvement is better than none, isn't it? Figure 28 shows that, for certain companies -- like Northeast Electric Development, Jilin Chemical Industrial, and Shandong Xinhua Pharma -- the large valuation uplift for listing in

\footnotetext{
${ }^{85}$ See Guo, Lin, Liang Tang, and Shia-Wee Yang, Corporate Governance and Market Segmentation: Evidence from the Price Difference between Chinese A and H Shares, Review of Quantitative Finance and Accounting 41(2), 2013, available online.

${ }^{86}$ See Klautzer, Lisa, Can Economic Openness Inspire Better Corporate Governance? An Exploration of the Link between Openness and Corporate Governance based on the Asian Experience, RAND RGSD-310, 2013, available online.

${ }^{87}$ Specifically "board characteristics" consists of proxies for the presence of foreign directors, the Board's international experience, the establishment of professional committees, board size, number of boards, proportion of independent directors, separation of chairman from general manager, and annual chairman changes. "Board control behavior" consists of attendance rates of independent directors, overall board attendance, independent directors' objections, rate of independent directors, performance review of the board, stock incentive mechanisms, the number of shareholders at general meetings, the number of extraordinary shareholder meetings, disclosure of business goals/ conditions and vision, the implementation of board resolutions, professionalism of committees' reports, number of institutional investors, and the equity ratio of the company's first major shareholders. See source for more details on the construction of these variables. See Zhou, Jian, Ting-ting Zhang, and Sheng-chao Cui, Cross Listing, Corporate Governance and Corporate Performance: Empirical Evidence of Hong Kong-Listed Chinese Companies, Nankai Business Review International 2(3), 2011, available online.

${ }^{88}$ See Pan, Lee-Hsien, Chien-Ting Lin , and K.C. Chen, ADR Characteristics and Corporate Governance in the Greater China Region, Review of Development Finance 2, 2012, available online.

${ }^{89}$ We soften our description of the results, given these authors' low statistic of variance-explained (or R-squared). Other authors, like Doidge and co-authors, show econometrically that better corporate governance rules account for premiums from a New York listing rather than a London one. See Doidge Craig, Andrew Karolyi, and Rene Stulz, Has New York become less competitive than London in global markets? Evaluating foreign listing choices over time, 2007, Journal of Financial Economics 91(3), 2009, available online.
} 
Hong Kong might make even such comparably weak corporate governance standards (compared to the US) profitable. ${ }^{90}$

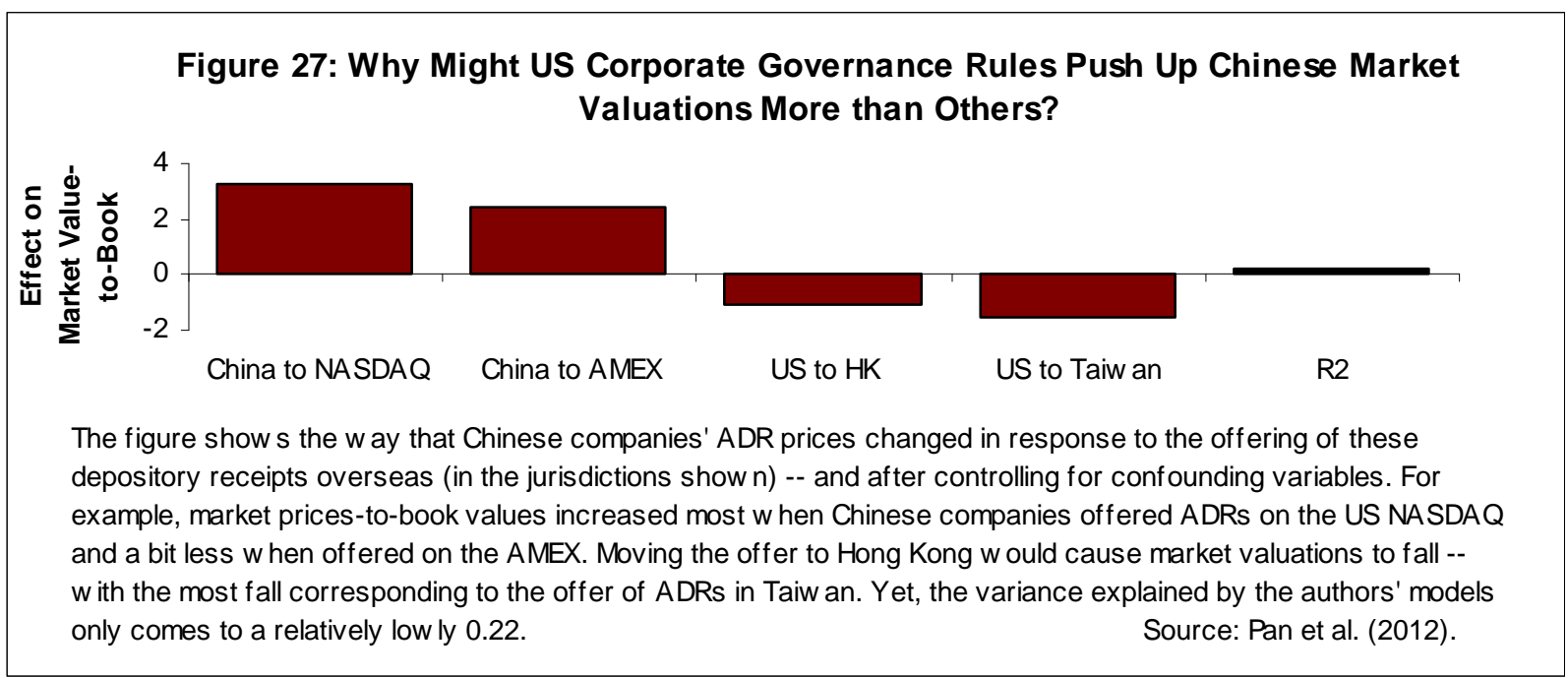

\section{Figure 28: Misleading Examples of Price Premia Earned by Listing in Hong Kong Rather than the Mainland}

\begin{tabular}{|c|c|c|c|}
\hline Premium & Companies & Premium & Companies \\
\hline \multirow[t]{4}{*}{$0 \%-50 \%$} & ZTE Corp. & $50 \%-100 \%$ & Anhui Expressway \\
\hline & Huaneng Power International & & China Shipping Development \\
\hline & Huadian Power & & China Petrol \& Chemical Corp. \\
\hline & China Southern Airlines & & Anhui Conch Cement \\
\hline \multirow{5}{*}{$100 \%-200 \%$} & Yanzhou Coal Mining & $200 \%-300 \%$ & Angang New Steel \\
\hline & Jiangxi Copper & & Jiangsu Expressway \\
\hline & Shenzhen Expressway & & Sinopec Yizheng Chemical Fibre \\
\hline & Tsingtao Brewery & & \\
\hline & Sinopec Shanghai Petrochem & & \\
\hline \multirow[t]{5}{*}{$300 \%-400 \%$} & Manshan Iron \& Steel & $400 \%-500 \%$ & None \\
\hline & China Eastern Airlines Corp. & & \\
\hline & Guangdong Kelon Electrical Holdings & & \\
\hline & Guangzhou Pharma & & \\
\hline & Guangzhou Shipyard Intl. & & \\
\hline \multirow[t]{6}{*}{$500 \%-600 \%$} & Jiaoda Kunji High-Tech & $600 \%-700 \%$ & Northeast Electric Development \\
\hline & Tianjin Capital Environmental & & Jilin Chemical Industrial \\
\hline & Protection & & Jingwei Textile Machinery \\
\hline & & & Beiren Printing Machinery \\
\hline & & & Dongfang Electrical Machinery \\
\hline & Shandong Xinhua Pharma & & Luoyang Glass \\
\hline
\end{tabular}

\footnotetext{
${ }^{90}$ See Guo, Lin Liang Tang and Shia-Wee Yang, Corporate Governance and Market Segmentation: Evidence from the Price Difference between Chinese A and H Shares, Review of Quantitative Finance and Accounting 41(2), 2013, available online.
} 
The figure shows the premia for dual-listed shares (on the Hong Kong and Mainland exchanges) for the shares shown. The authors argue that a premium on A-shares (listed on the Mainland) represents the ability of insiders to extract value from investors. Thus, in Hong Kong as a better market, investors would pay a lower price and expect the share price appreciation shown.

Source: Guo et al. (2007).

The following table shows the industries more likely to profit - and thus import -- good corporate governance standards. ${ }^{91}$ If Bris et al.'s study still reflects the current situation among Chinese firms, roughly 11 out of 30 industries can expect to adopt market valuation increasing corporate governance practices. ${ }^{92}$ These eleven sectors appear relatively specific (specialised). One might thus hypothesize that managers can adopt profit-enhancing corporate governance reforms in easily managed sectors only. Yet, corporate governance looks particularly pressing for some sectors. The real estate, IT and retail sectors affect China's broader macroeconomic stability and growth. If the current system can not provide the incentives needed to adopt profitenhancing corporate governance reforms in the sectors that most need them (like banking, real estate and so forth), then the system needs changing.

\section{Figure 29: Sectors Where Importing Corporate Governance Standards Has Affected Tobin's $q$ for Chinese Firms in the Past}

$\begin{array}{lll}\text { Effect } & \text { No effect } & \\ \text { Construction } & \text { Autos } & \text { IT } \\ \text { Healthcare } & \text { Beverages } & \text { Leisure goods } \\ \text { Steel } & \text { Electricity, water, gas } & \text { Mining } \\ \text { Pharma and biotech } & \text { Engineering } & \text { Oil and gas } \\ \text { Media } & \text { Food and drug retailers } & \text { Personal goods } \\ \text { Specialty finance } & \text { Food producers } & \text { Real estate } \\ \text { Mobile telecom } & \text { Forestry \& paper } & \text { Retail } \\ \text { Tobacco } & \text { Household goods } & \text { Software and computer } \\ \text { Travel/leisure } & & \text { Support services } \\ \text { Diversified Industrials } & & \text { Water } \\ \text { Electronics } & & \end{array}$

The figure shows the industries for which Tobin's q statistically significantly changed due to differences in shareholder protection or accounting standards between China and another jurisdiction from which target firms hail during an M\&A. The authors argue that importing corporate governance policies and practices causes these changes in market valuations.

Source: Bris et al. (2008) at table 8.

Little evidence seems to support foreign listings as "bonding” Chinese firms to stricter corporate governance rules. Dong and Xue test the extent of such bonding, looking at the extent to which corporate governance related variables (like board size, compensation and other factors) statistically significant differ between Chinese firms listed in Shanghai/Shenzhen, in Hong Kong or in New York. ${ }^{93}$ They find some factors, like the salaries of the top three board members, and

\footnotetext{
${ }^{91}$ See Bris, Arturo, Neil Brisley, and Christos Cabolis, Adopting Better Corporate Governance: Evidence from Cross-Border Mergers, Journal of Corporate Finance 14(3), 2008, available online.

92 The situation may not hold, as these sectors might have already adopted all the corporate governance reform they can.

${ }^{93}$ See Dong, Min-yue and Qing-mei Xue, Local versus global: Corporate governance practices in Chinese domestic and overseas companies, International Journal of Disclosure and Governance 6(4), 2009, available online.
} 
local demand conditions, and all kinds of public disclosure statistically significant differ for firms choosing to list on different exchanges. ${ }^{94}$ Yet, factors like board sizes or the proportion of independent directors do not differ - putting into doubt the extent of such bonding. Authors like Clarke write even more sceptically about bonding. ${ }^{95}$ He argues moreover that whether Chinese firms "bond" to foreign corporate governance requirements and values, such rules would not protect investors any more than rules at home in China. Consequently, any share price premium paid by investors comes from their misplaced belief in the likely success of legal action should these Mainland listed companies run into difficulties. Grove and Clouse might agree - citing Longtop Financial Technologies, China MediaExpress, Harbin Electric, China-Biotics and Deer Consumer Products as companies delisted in New York for fraud. ${ }^{96}$ Simply listing on the Hong Kong stock exchange will not provide sufficient impetus for improving (importing) better corporate governance practices on the Mainland.

Maybe only the indirect effects of better corporate governance rules help improve market discipline - and thus owners'/managers' incentives to maximise shareholder value? We have shown above that better corporate governance's direct effects do not seem to improve shareholder value. What about corporate governance’s indirect effects - encouraging transparency and disclosure needed for investors to price and trade Chinese firms' shares accurately? ${ }^{97}$ If Hong Kong's corporate governance rules reduce information asymmetries between investors and insiders, share prices should better reflect such firm-specific information. ${ }^{98}$ Yet, Figure 30 very much casts doubts on the extent to which better corporate governance leads to more informative share prices (which reflect firm-specific, rather than general market-related, news). ${ }^{99}$ Hong Kong share turn-over of Mainland companies does increase, relative to Mainland share turnover for cross-listed shares, in response to firm-specific events (news). Yet, adoption of the practices usually considered as part of good corporate governance fail to make share prices in Hong Kong more responsive to firm-specific news. Such irrelevant factors include institutional ownership, independent directors, and even lack of shareholder concentration. Simply listing in Hong Kong does not guarantee that Mainland companies receive the benefits of (or discipline from) better corporate governance.

\footnotetext{
${ }^{94}$ Id at Table 3.

95 See Clarke, Donald, The Bonding Effect in Cross-Listed Chinese Companies: Is it Real?, GWU Law School Public Law Research Paper No. 2015-55, 2015, available online.

${ }^{96}$ See Grove, Hugh and Maclyn Clouse, Corporate Governance Standards in Cross-Border Investing: Lessons Learned from Chinese Companies Listed in the United States, 2013, available online. Lee and colleagues dispute these claims, particularly in relation to Chinese reverse mergers (backdoor listings) into the US. They note that even after accounting for fraudulent firms, these companies do better as a group than their US peers. See Lee, Charles, Kevin Li, and Ran Zhang, Shell Games: The Long Term Performance of Chinese Reverse Merger Firms, Stanford School of Business Working Paper, 2014, available online.

${ }^{97}$ In this context, “accurately” refers to investors' ability to observe information signalling likely mismanagement, self-dealing, and other problems.

${ }_{98}$ As in the previous sentence, we do not explicitly define our terms (in this case "information asymmetry") as managers and owners knowing about their own self-serving, neglect, fraud or even excessive risks which investors can not properly value. Without abandoning our scientific precision, we can not accurately describe every concept in several sentence. Otherwise, readers would be unable to read such dense and long-winded writing.

${ }^{99}$ See Li, Shan, Paul Brockman and Ralf Zurbruegg, Cross-listing, firm-specific information, and corporate governance: Evidence from Chinese A-shares and H-shares, Journal of Corporate Finance 32, 2015, available online.
} 
Figure 30: Does the Increased Transparency from Supposedly Better Corporate Governance Really Make Hong Kong Share Price Movements of Mainland Companies More Informative?

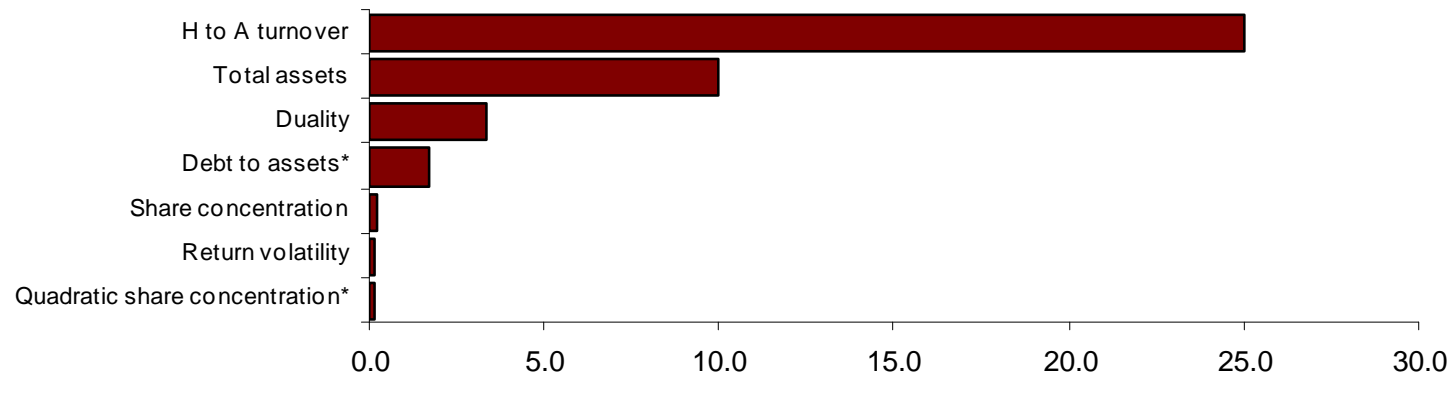

Extent of firm-specific information in price movements (larger is "better")

\begin{abstract}
Not significant variables: Percent of shares held by domestic funds, the ratio of H-shares to A-shares, the number of QFIl investors among the top 10 shareholders, the number of board-level directors, percent of independent nonexecutive directors, the number of members of supervisory boards, CEO pay, use of shares to incentivise CEOs, Tobin's $q$, and the number of foreign subsidiaries.

The figure show s the extent to $w$ hich each of the factors show $n$ affects the extent to which share price changes reflect company-specific information (commonly know $n$ as a share's synchonicity). We show the inverse of the authors' regression parameter estimates in order to make firm-specific factors score higher in the figure. We w orry about the large number of factors Typically associated with classical corporate governance which turn up as insignificant in this study. The authors' application of incorrect econometric techniques most likely explain these results.

Source: Li et al. (2014).
\end{abstract}

The recent bout of Mainland company fraud strongly suggests that foreign listings, and their supposedly stricter corporate governance rules, do not lead to better governed Mainland firms. Figure 31 shows how fraud has significantly reduced market valuations of Mainland shares listed abroad - as reflected in several FTSE indices. ${ }^{100}$ Shares of Chinese companies listed on the Mainland (A shares in particular) have yielded positive returns since 2011. Yet, a recent correction has shown that these previous gains did not reflect knowledge about frauds going on at the time. ${ }^{101}$ The prices of Mainland shares listed and traded in the US - and particularly Singapore -- have seen the largest declines. ${ }^{102}$ High levels of demand in Hong Kong for Chinese shares explain why share prices have not fallen as rapidly on the Hong Kong bourse. Fraud contributed to the large sell-off of securities in the US - with about $1 / 3$ of all Chinese companies listed in the US had financial scandals. ${ }^{103}$ Indeed, the lower part of Figure 31 shows that the sell-

\footnotetext{
100 See FTSE Russell, FTSE Factsheet: FTSE China Share Class Indexes, 2016, available online. See also Cogman, David and Gordon Orr, How they fell: The collapse of Chinese cross-border listings, McKinsey \& Co., 2013, available online.

${ }^{101}$ For readers unfamiliar with these frauds, see Yu, Xie, China likely to delist more problematic companies in 2016, South China Morning Post, 2016, available online.

102 S-shares receive very little analysis in the English language press and among English-language academics. Thus, we can not speculate about the reasons for the S-share's price changes in Singapore.

103 Beatty and co-authors provide a superlative account of these frauds as well as related econometric analysis. See Randolph Beatty, Hai Lu, Wei Luo, The Market for "Lemons”: A Study of Quality Uncertainty and the Market Mechanism for Chinese Firms Listed in the US, 2013, available online. For the 1/3 figure, and other in-depth facts
} 
off centred on small cap shares (whose companies have the weakest corporate governance) the heaviest. Some Mainland companies look toward listing “transfers.” These transfers entail Chinese companies' delisting in the US or other foreign markets in order to relist at home in China. ${ }^{104}$ Some companies probably seek to cash-in on the fraud and run away before news of such fraud catches up with their share prices. Others seek to avoid the extra scrutiny. Yet, exchanges all over the world engage in the wrong policy in relation to these errant Mainland companies. Rather than try to block potentially fraudulent Mainland companies them listing, policymakers would do better to put in place monitoring and enforcement schemes that encourage managers to govern their corporations in the interests of outsiders as well as insiders.

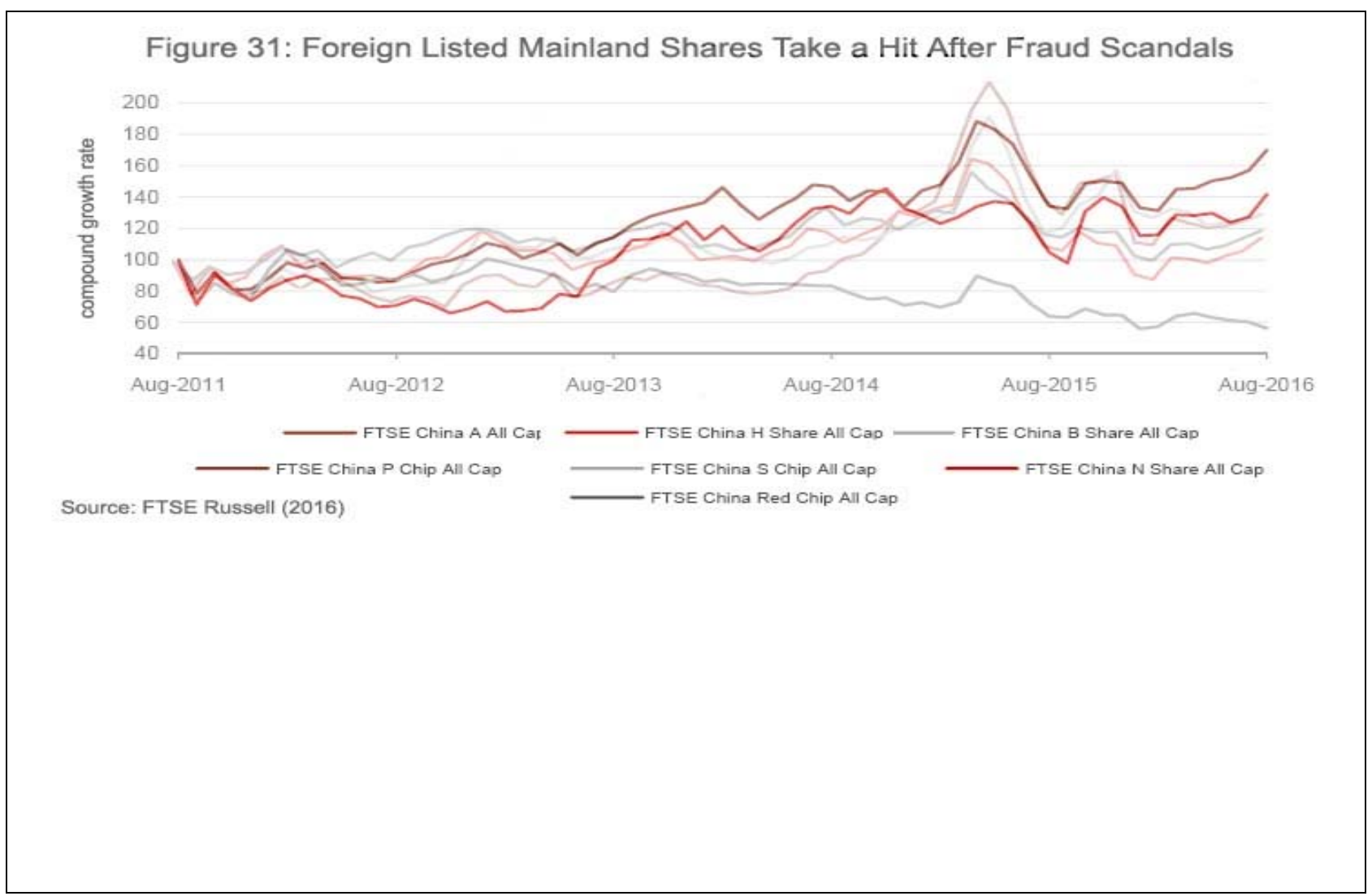

Yet, enforcement of all securities rules - not just those related to corporate governance - clearly show the Mainland authorities can not offer a sufficient enough deterrent on poor corporate governance practices to change corporate governance standards at a national level. In 2010, Professor Clark documented almost non-existent enforcement of Mainland securities rules noting less than $1 \%$ of all companies censured. ${ }^{105}$ By 2016, publicly available information from

about these frauds, see Ang, James, Zhi-Qian Jiang, and Chao-Peng Wu, Good Apples, Bad Apples: Sorting Among Chinese Companies Traded in the U.S., Journal of Business Ethics 134(4), 2016, available online.

${ }^{104}$ See Gu, Wei, Scrutiny Greets Overseas-Listed Chinese Companies Returning Home to Relist, Wall Street Journal, 2016, available online.

105 Clarke, Donald, Law without Order in Chinese Corporate Governance Institutions, Northwest Journal of International Law and Business 30(131), 2010, at p. 185, available online. 
2014 showed little improvement - with only 74 cases referred to the police. ${ }^{106}$ If the CSRC started 488 investigations in 2014, the Commission closed only 163 cases in that same year with the backlog of cases rising. ${ }^{107}$ Even having government officials sit on Mainland companies' boards does not seem to improve corporate governance practices and enforcement. As Tin and co-authors show in their econometric study, more government officials on Mainland boards correlate with more earnings management and ineffective (even if they are independence) audit committees. ${ }^{108}$ Corporate governance enforcement (and thus compliance) on the Mainland will not occur often, unless a credible, outside actor engages in enforcement effort with the full-backing of the government of the People's Republic.

Experts calling for the Mainland to import foreign corporate governance rules (either directly or through foreign listings) thus miss the point. Dai in particular illustrates the futility of making these kinds of recommendations. ${ }^{110} \mathrm{He}$ argues for stronger disclosure rules in the US for Chinese firms (and others) listing there - specifically disclosing corruption risks. Because Chinese firms deal with much higher corruption risks than US and other firms, such a rule would help Chinese issuers disclose information they would be unable to disclose at home. Yet, recommendations like this ignore the enforcement issue. Why should Mainland companies comply? In contrast, extra-territorially applied rules from jurisdictions like the US have demonstrated their ability to affect change abroad. ${ }^{111}$ Only rules which give the explicit mandate to securities law enforcement officials from a jurisdiction with high levels of corporate governance to work with foreign governments (and especially the Mainland) will likely move corporate governance forward in China.

\section{How Do We Know that Moving Hong Kong Regulations and Enforcement North Can Help?}

What does the US (and other countries') experience with extra-territorial and aggressive crossborder investigation/enforcement of corporate governance related rules tell us about using such provisions to help clean up China's corporate governance? The US has adopted two major legislative instruments giving extra-territorial reach to its corporate governance - Sarbanes-Oxley Act of 2002 and the Dodd-Frank Wall Street Reform and Consumer Protection Act of $2010 .^{112}$

\footnotetext{
${ }^{106}$ China Securities Regulatory Commission, 2014 Annual Report, at p. 3, available online.

${ }^{107}$ Id at p. 30.

${ }^{108}$ Lin, Teng, Marion Hutchinson and Majella Percy, Earnings management and the role of the audit committee: an investigation of the influence of cross-listing and government officials on the audit committee, Journal of Management \& Governance 19(1), 2015, available online.

${ }^{109}$ We can not provide a taxonomy of the cases where such outside influence changed enforcement and compliance norms in a jurisdiction. US “cooperation” by sending experts to reform foreign laws represents one obvious - and futile - way of encouraging reform from the outside. The EU's latest accession provides much interesting fodder for readers interested in seeing a historical case of a jurisdiction importing rules and enforcement from abroad. For the first perspective, see De Lisle, Jacques, Lex Americana?: United States Legal Assistance, American Legal Models, and Legal Change in the Post-Communist World and Beyond, University of Pennsylvania Journal of International Economic Law 20, 1999. For the second perspective, see Ialnazov, Dimiter, The Impact Of EU Accession on Corporate Governance Reform in Bulgaria, Acta Oeconomica 57(2), 2007, available online.

${ }^{110}$ Dai, Xin, Disclosing China’s Corruption Risks: A Securities Regulation Perspective, Duke Journal of Comparative \& International Law 24, available online.

${ }^{111}$ Anti-corruption law represents the most obvious example. See Lippitt, Anne, An Empirical Analysis of the Foreign Corrupt Practices Act, Virginia Law Review 99(8), 2013, 2013, available online.

112 To keep this paper at a reasonable length, we can not review these pieces of legislation in-depth. We refer to the relevant corporate governance provisions during the course of our analysis. For an excellent overview and
} 
The rule of thumb in applying extra-territorial jurisdiction has traditionally consisted of whether the "conduct" or "effects" of a legal infraction abroad significantly affect the US. ${ }^{113}$ Hong Kong law clearly does not balk at the idea of adopting such a conduct-effects test - as the recent Competition Ordinance makes clear. ${ }^{114}$ A Department of Justice proposal to implement national security provisions of the Basic Law "considered that the Legislative Council has the power to enact laws having extra-territorial effect where those laws have a sufficient connection with the Hong Kong SAR." "115 We do not wish to debate whether extra-territoriality should apply to national security or the merits of the now defunct National Security Bill. ${ }^{116}$ Instead, we merely wish to note that a consensus opinion around the legality and legitimacy of extraterritoriality in Hong Kong law allows for the possible application of such limited extraterritoriality in Hong Kong's corporate governance rules.

The econometric evidence on US extra-territorial application shows that Mainland might well benefit from such rules. Figure 32 shows the effect of the Sarbanes-Oxley Act on the market premia of various types of firms. ${ }^{117}$ The positive effects on foreign firms seem to exceed those of all firms analysed as a single group. Only small foreign firms only seem to gain less market valuation relative to large foreign firms - an effect we already saw in the case of Mainland listings (due to fraud risk). How did particular aspects of these firms' corporate governance influence the excess returns accruing to these firms after the adoption of the Sarbanes-Oxley Act? The figure also shows that, for the whole lot of firms, factors like having an independent nominating committee, independent audit committee, having a CEO which does not serve as chairperson, low inside share ownership, high institutional share ownership, low audit fees as share of total assets, and low market capitalisation all lead to large post-Sarbanes Oxley effects on extra (abnormal) returns. Yet, among foreign firms, only the corporate governance factor of having an independent nominating committee seemed to boost these excess returns. These

\footnotetext{
compare/contrast of these two pieces of legislation, see Holcomb, John, Corporate Governance: Sarbanes-Oxley Act, Related Legal Issues, and Global Comparisons, Denver Journal of International Law and Policy 32(2), 2004, available online.

${ }^{113}$ We put conduct and effect in quotes to signal the test US courts have traditionally used in deciding whether to judge a case with extra-territorial aspects. We cover specifics in more detail in the next section. Yet, for readers who need a quick and simple overview, see Robert Giuffra, The Territorial Reach of U.S. Securities Laws After Morrison v. National Australia Bank, Harvard Law School Forum on Corporate Governance and Financial Regulation, 2011, available online.

${ }^{114}$ Article 8 of the Competition Ordinance dealing with "territorial application” "applies to an agreement, concerted practice or decision that has the object or effect ... even if — the [agreement, practice, party, association] is made or given effect to outside Hong Kong” (underlining ours, with the original text converted from list form to sentence form and with the text in brackets summarising four sub-points in order to make the text easier to read).

${ }^{115}$ Department of Justice, National Security (Legislative Provisions) Bill: Application of the proposed subversion and secession offences outside Hong Kong, 2003, available online.

${ }^{116}$ For more background, see Fu, Hua-Ling, and Richard Cullen, National Security Law in Hong Kong: Quo Vadis A Study of Article 23 of the Basic Law of Hong Kong, Pacific Basin Law Journal, 19(2), 2002, available online.

117 The authors obviously made some mistake in their calculations, as the standard deviations they report for the statistically significant results which we cite here exceed the mean values by a factor of 10 . We assume the authors rescaled the data and forgot to report the rescaling. See Switzer, Lorne and Lin Hui, The Long-term Valuation Impact of Sarbanes-Oxley on U.S. vs. Foreign Firms, International Journal of Business Governance and Ethics 4(4), 2009, available online.
} 


\section{results thus suggest that corporate governance regulatory reform would likely help even foreign companies that have not embarked on their own corporate governance reforms. ${ }^{118}$}

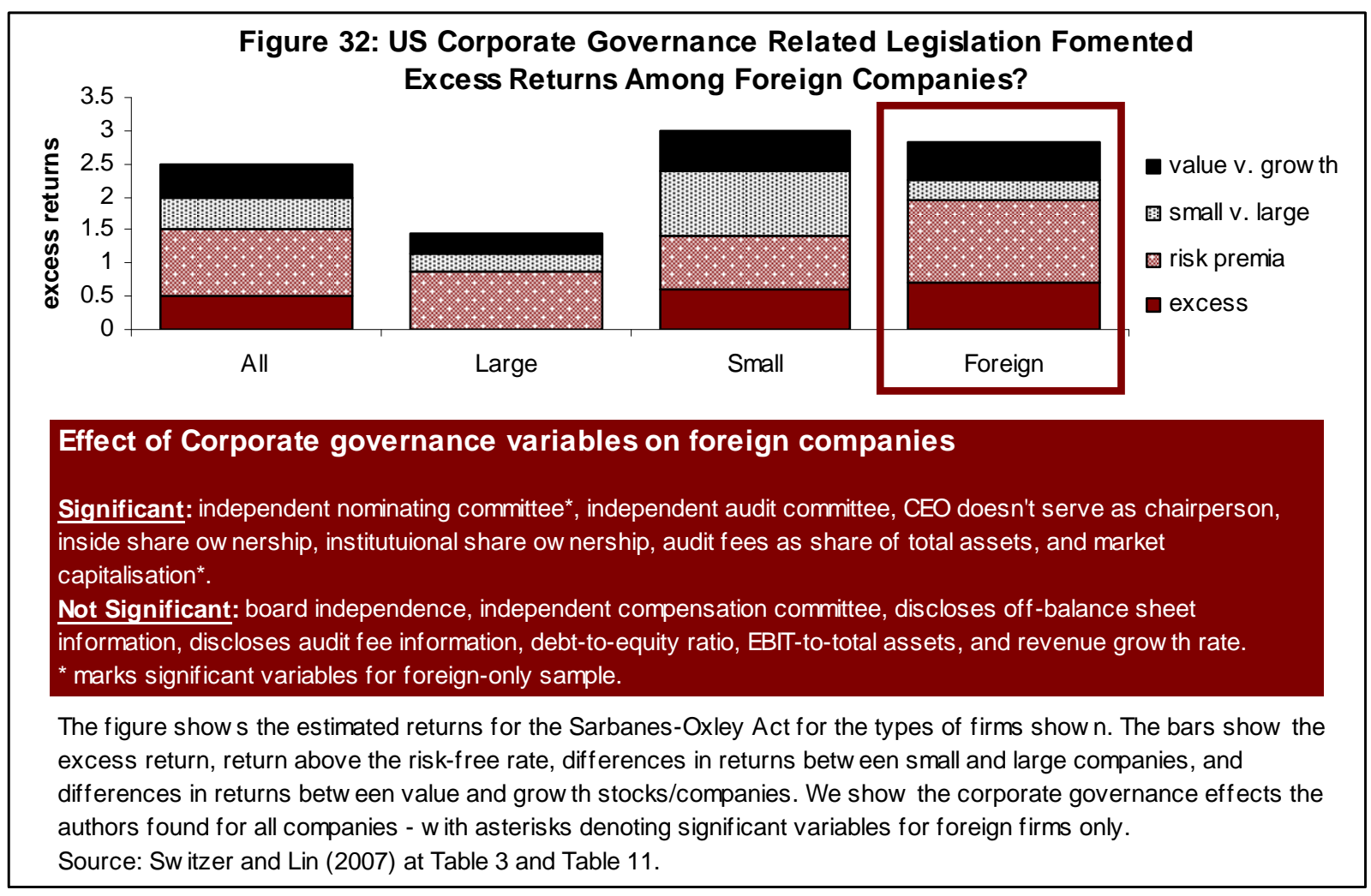

Other data seem to support the view that stronger corporate governance regulations could benefit Mainland (and other foreign) firms. Figure 33 shows the gain in abnormal returns and decreased delistings for non-US firms listed in the US as a result of the adoption of the Sarbanes-Oxley Act. ${ }^{119}$ In summary, the authors find that foreign companies listed in the US most benefited from Sarbanes-Oxley when they come from jurisdictions with moderate accounting standards and shareholder protection. To put their findings colloquially, foreign firms "bond” (adapt more stringent corporate governance policies) when coming from jurisdictions with Goldilocks corporate governance -- not too bad and not too good. ${ }^{120}$ Looking specifically at the way

\footnotetext{
${ }^{118}$ This conclusion's logic is as follows. Having these various corporate governance attributes does not affect the Sarbanes-Oxley Act's effect on excess market returns. Yet, we see that these returns clearly increased for foreign firms. Thus, some combination of these reforms contributes to these excess returns (or completely outside factors account for these returns). Yet, coming from different jurisdictions, industries and so forth, these firms do not have common factors affecting them which might point to non-corporate governance related effects.

${ }^{119}$ Technically, the study looked at these variables before and after the adoption of the Act. We follow the authors' language trying to tie such a correlation to causality. See Smith, Geoffrey, Sarbanes-Oxley and the Foreign Issuer: A Test of the Bonding Hypothesis, 2005, available online.

${ }^{120}$ To take one example, Amoako-Adu and Baulkaran show how Canadian firms listed in the US lost market value de to the implementation of Sarbanes-Oxley. See Amoako-Adu, Ben and Vishaal Baulkaran, The Effects of the Sarbanes-Oxley Act and Canadian Equivalent, Bill 198/CSA Rules, on Canadian Cross-Listed Stocks, 2007, available online.
} 
Sarbanes-Oxley impacted on company risks, Litvak finds that a similar Goldilocks phenomenon. ${ }^{121}$ High risk foreign firms' risks fell after the adoption of Sarbanes-Oxley. However, their market valuations also fell. Only large companies from poorer jurisdictions complied with the Act - whereas all companies seemed to comply from other jurisdictions. These result though still our own basic analysis shown in the previous section - that Mainland's companies' corporate governance quality is solid enough to push through further reform but not so good as to continue without reform.

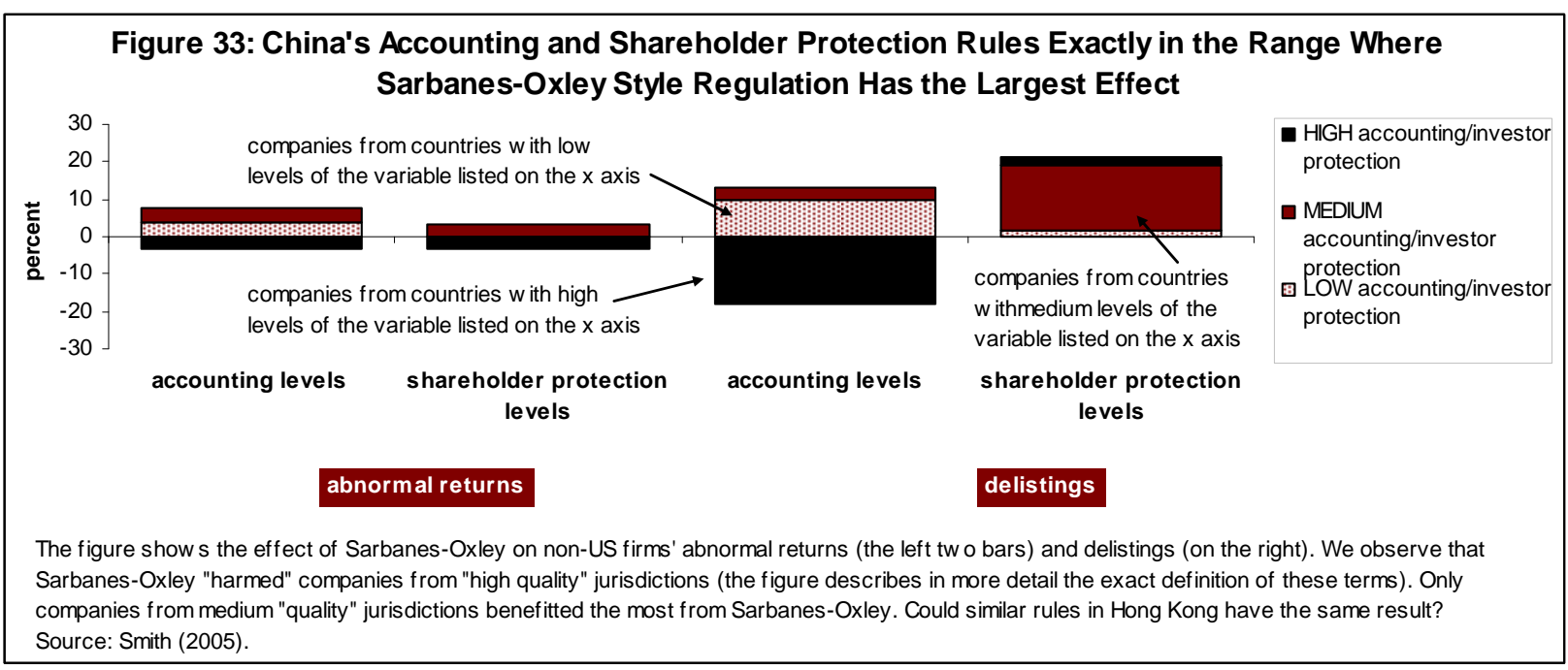

Not to belabour the point, but other evidence suggests that corporate governance pressure from outside the Mainland would have a palliative effect on such governance on the Mainland. Figure 34 shows the relationship between the percent of companies listing abroad in a particular Chinese city or region and the quality of local institutions in that area. ${ }^{122}$ Just by eye-balling the data, we can see that more companies from places with higher institutional quality list abroad more often. Thus these companies can, and do, conform with these foreign exchanges' more stringent corporate governance rules. Yet, within each grouping of places (by institutional quality), we see that Chinese firms from places with worse lower institutions (relative to similar regions) tend to list abroad more often. ${ }^{123}$ Such a propensity suggests that Mainland firms use foreign listings as a way to import standards needed to compete with peers who work in better institutional environments. Both these trends suggest that maybe Mainland firms would benefit from having more stringent corporate governance rules foisted upon them.

\footnotetext{
${ }^{121}$ Litvak, Kate, Defensive Management: Does the Sarbanes-Oxley Act Discourage Corporate Risk-Taking? University of Illinois Law Review, 2014, available online.

${ }^{122}$ See Hornstein, Abigail, The impact of local governance institutions on foreign market listings: The case of Chinese firms, China Economic Review 29, available online.

${ }^{123}$ In order to keep this paper readable, we do not yet again provide the definition of institutions (or institutional quality). Readers should see the original study for more details.
} 


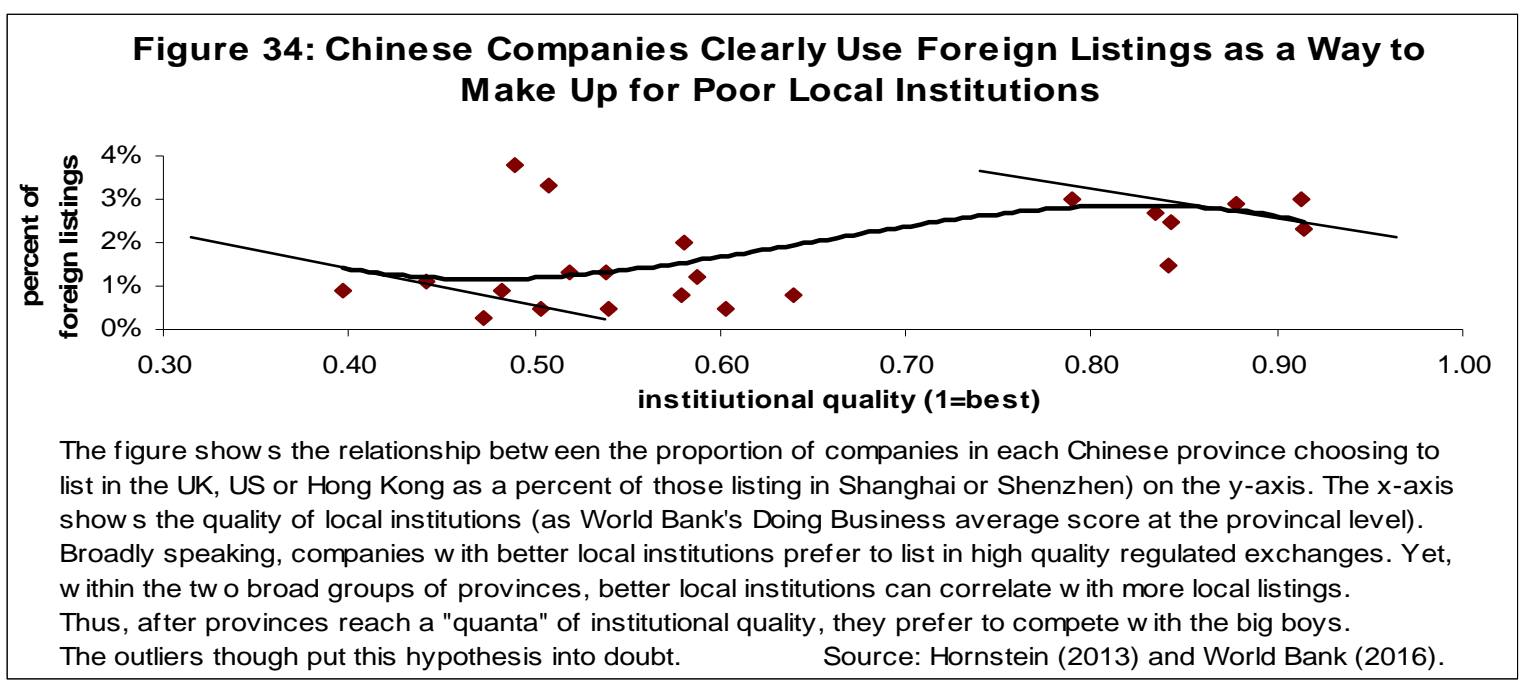

What kinds of gains can Mainland firms expect if Hong Kong's corporate governance rules increasingly bind on them? If Sarbanes-Oxley Act serves as any guide, Mainland firms could lower their capital costs by $0.7 \%$ to $1 \% .{ }^{124}$ Piotroski and Srinivasan find that Sarbanes-Oxley did not distort foreigners' incentives to list on foreign markets. ${ }^{125}$ Instead, worse governed companies had to delist (or face the extra compliance costs) - thereby improving market quality and shareholder protection for all listed companies. ${ }^{126}$ Of course, not all companies - and especially small firms -- should have the same stringent corporate governance requirements. ${ }^{127}$ Engel et al., using relatively old data whose conclusions still apply to today's situation, find that companies with more insider (managers'/directors') shareholding delisted much more than those with more dispersed shareholding. ${ }^{128}$ They further find that the abnormal returns to insider controlled companies which delisted around the time of the Sarbanes-Oxley Act's adoption exceeded those of their control group by $6 \% .{ }^{129}$ Evidence from Belgium shows that the Act had the effect of actually the improving corporate governance of US listed overseas companies - by causing decreases in earnings management (and thus likely other kinds of accounting

\footnotetext{
${ }^{124}$ See Hail, Luzi and Christian Leuz Cost of Capital Effects and Changes in Growth Expectations around U.S. Cross-Listings, Wharton Financial Institutions Center Working Paper 06-19, 2008, available online.

${ }^{125}$ Economists care about relative distortions in a market more than the size of the market - as pure changes in size only affect marginal incentives (and do not change the distribution of resources or investment decisions). See Srinivasan, Suraj and Joseph Piotroski, Regulation and Bonding: The Sarbanes-Oxley Act and the Flow of International Listings, Rock Center for Corporate Governance Working Paper 11, 2008, available online.

${ }^{126}$ Hostak and his co-authors represent one of the many other studies to confirm these findings. See Hostak, Peter, Emre Karaoglu, Thomas Lys and Yong Yang, An Examination of the Impact of the Sarbanes-Oxley Act on the Attractiveness of US Capital Markets for Foreign Firms, Review of Accounting Studies 18(2), 2013, available online. ${ }^{127}$ See Wintoki, Babajide, Corporate Boards and Regulation: The Eect of the Sarbanes-Oxley Act and the Exchange Listing Requirements on Firm Value, Journal of Corporate Finance 13(2-3), 2007, available online. See also Grinstein, Yaniv, and Vidhi Chhaochharia, Corporate Governance and Firm Value: The Impact of the 2002 Governance Rules, Journal of Finance 62(4), 2007, available online.

${ }^{128}$ Engel, Ellen, Rachel Hayes, and Xue Wang, The Sarbanes-Oxley Act and Firms' Going-Private Decisions, Journal of Accounting and Economics 44(1-2), 2007, available online.

${ }^{129}$ We calculated this statistic by taking the differences-in-differences of pre and post Sarbanes Oxley data and of delisters from control group companies (as reported in Table 7).
} 
manipulation). ${ }^{130}$ As such, forcibly stricter corporate governance rules improve investment returns, even if these policies decrease the discretionary influence of insider managers and directors.

Because poor corporate governance sometimes involves hard-to-prove crimes across borders, extra-territorial work represents the best bet to tackle the underlying cause of crime - stopping the crime at its source. ${ }^{131}$ Figure 35 for example shows data from a recent popular study of shell companies. ${ }^{132}$ Of the 150 cases of grand corruption the authors analysed, 112 possessed a transnational element. The US and BVI represent the most popular jurisdictions for incorporating the corporate vehicles used in the subsequent crime/corruption case. Hong Kong appears rather prominently on this list of jurisdictions where corrupt individuals incorporate and establish bank accounts. As we have analysed previously, badly governed Chinese firms have a much higher probability of engaging in cross-border corruption, bribery and money laundering than their wellgoverned peers. ${ }^{133}$ China will not be able to fight corruption without cleaning up corporate governance practices. ${ }^{134}$ Most analysts note that jurisdictions should work cross-borders, provide assistance and no more. Yet, extra-territorial work on corporate governance actually increases the likelihood of mutual legal assistance and cross-border cooperation.

\footnotetext{
${ }^{130}$ See Dutillieux, Wouter and Marleen Willekens, The Impact of SOX On Earnings Quality Outside the U.S: Evidence from Belgian Subsidiaries of U.S. Listed Companies, Catholic University of Leuven Department of Accounting, Finance and Insurance Working Paper 0725, 2009, available online.

${ }^{131}$ As a simple illustration, several studies show decreases in earnings manipulation from Sarbanes-Oxley. See Blair, Emily, The Effect of the Sarbanes-Oxley Act of 2002 on Earnings Quality, 2016, available online.

132 See Willebois, Emile, Emily Halter, Robert Harrison, Ji-Won Park and J.C. Sharman, The Puppet Masters: How the Corrupt Use Legal Structures to Hide Stolen Assets and What to Do About It, 2011, available online.

${ }^{133}$ Many authors argue that guanxi relationships explain how self-serving relationships of insiders to expropriate outsiders simultaneously facilitates corruption/bribery and even sending money offshore. See Cai, Hong-Bin, HanMing Fang, Li-Xin Xu, Eat, Drink, Firms and Government: An Investigation of Corruption from Entertainment and Travel Costs of Chinese Firms, NBER Working Paper No. 11592, 2005, available online. See also Wu, Xun, Corporate Governance and Corruption: A Cross-Country Analysis, Governance: An International Journal of Policy, Administration and Institutions, 18 (2), 151-170, 2005, available online.

${ }^{134}$ We do not want to discuss the link between corporate governance and corruption too much in this paper. For evidence on these linkages, see Wu, Xun, Corporate Governance and Corruption: A Cross-Country Analysis, Governance 18(2), 2005, available online.
} 


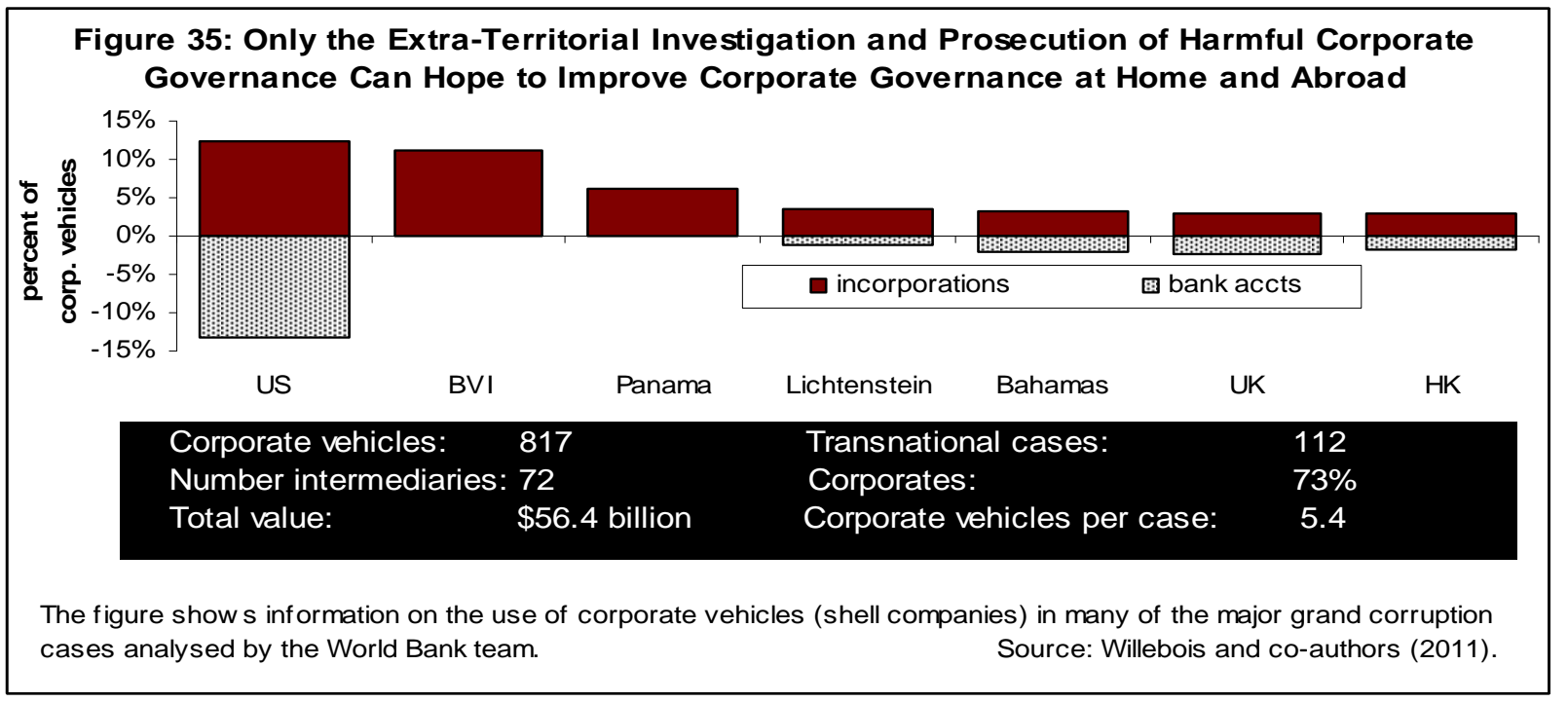

If the US experience holds, other jurisdictions will likely not resist extra-territorial application of such corporate governance rules. Vagts, as early as 2003, noted in his discussion of SarbanesOxley (the first law to theoretically apply extra-territorial corporate governance rules), that the EU and other countries did not formally object to such application. ${ }^{135}$ Individual academics and social crusaders may grumble - but most see reasoned and moderate extra-territorial application in good taste. Indeed, he further notes that securities and other business increased over-seas as a result of such extra-territorial application. ${ }^{136}$ As US companies had to comply with the same rules at home or abroad, they found they could exploit the benefits afforded to them by the law, without costly managing multiple regulations. International experience supports the assertion that limited extra-territorial application of corporate governance law thus increases a country's corporate activity outside of its borders. ${ }^{137}$

\section{Hong Kong's Helping Hand for the Mainland's Corporate Governance Problems}

\section{The Rationale for Extra-Territorial Corporate Governance Law and Rules}

The Legislative Council clearly has arguably the power to enact extra-territorial legislation. In a 2003 brief looking at the extra-territorial application of national security laws, the Hong Kong Department of Justice considered more generally the question of whether the LegCo had the competence to enact legislation applying beyond Hong Kong's borders. ${ }^{138}$ As a result of two orders, Hong Kong Order of 1986 and later 1989, under the Hong Kong Act, Hong Kong may apply laws agreed by international treaty extra-territorially. ${ }^{139}$ Citing law professor Peter Wesley-

\footnotetext{
${ }^{135}$ Vagts, Detlev Extraterritoriality and the Corporate Governance Law, American Journal of International Law 97(2), 2003, available online.

136 Id at p. 293.

137 The author further rightly notes that such rulemaking may over-burden regulators who must survey activity abroad as well as at home. And in case foreign regulators or courts enter in case, they must similarly use resources in negotiating with these parties.

${ }^{138}$ Department of Justice, National Security (Legislative Provisions) Bill: Extraterritoriality, Paper 50, 2003, available online.

${ }^{139}$ Id at Annex I, p.5.
} 
Smith, Wesley-Smith finds a possible rationale under existing law if the "nexus” between Hong Kong and the foreign act bears a "real or substantial relation" to Hong Kong. ${ }^{140}$

Yet, such a rationale relies on two legal artifices. First, most arguments in support of extraterritoriality apply to rulemaking under the British Empire. Second, citing the supposed Piggott Doctrine, the Queen of that time did not strike down the extra-territorial application of law -- in a historical version of silence-equal-consent. ${ }^{141}$ For Judge Power JA, any law promoting the "peace, order and good government” of Hong Kong which applies in Hong Kong may receive extraterritorial treatment. Arguments from lawyers like Mok clearly suggest that Hong Kong's legal community considers extra-territorial application of corporate governance not only possible, but necessary. ${ }^{142}$

The Hong Kong (Legislative Powers) Order 1986 clearly intended for the LegCo to have the competence to rule extra-territorially. ${ }^{143}$ Confusion shortly surfaced as to whether such powers extended only to civil aviation, merchant shipping and admiralty. Or whether the powers applied more generally. Wesley-Smith cites a tax case, which attracted extra-territorial jurisdiction as per British imperial rulings of the time. ${ }^{144}$ The Companies Ordinance imposes several requirements on companies not in Hong Kong. ${ }^{145}$ Yet, in the case of the extra-territorial application of Hong Kong's anti-corruption law, courts have pushed back against attempts to interpret the Prevention of Bribery Ordinance extra-territoriality. ${ }^{146}$ The Legislative Council needs to expressly write extra-territorial provisions, given the uncertainty and vagueness around the extent to which laws can apply extra-territorially. If violations of Hong Kong's corporate governance rules by Hong Kong listed companies abroad will attract extra-territorial liability only for the rules enshrined in hard law. ${ }^{147}$

Politics should - and will - determine which corporate governance principles apply extraterritorially. As a political decision, Legislative Council members would need to add extraterritoriality to the Companies Ordinance and/or Securities \& Futures Ordinance depending on the outcome of political bargaining. Relevant provisions from the Sarbanes-Oxley Act include corporate responsibility for financial reports, management assessment of internal controls, real time issuer disclosures, attempts and conspiracies to commit fraud offenses, and corporate responsibility for financial reports. ${ }^{148}$ Relevant concepts from the Dodd-Frank Act

\footnotetext{
${ }^{140}$ Id, citing Peter Wesley-Smith, Constitutional and Administrative Law, at p. 207.

${ }^{141} \mathrm{Id}$ at sec. 752.

142 Id. at sec. 5 .

${ }^{143}$ Id at sec. 7.5.3.

${ }^{144}$ Id at Annex 2, $3^{\text {rd }}$ to the last sentence.

145 See Companies Ordinance, Chap. 622, available online.

${ }^{146}$ For the law, see Prevention of Bribery Ordinance, Chap. 201, 1971, available online. For a recent discussion of the courts' treatment of the extra-territorial treatment of that ordinance, see also Rohlik, Philip and Sebastian Ko, Hong Kong Court Rules on Extraterritorial Limits to the Territory's Anti-Corruption Law, FCPA Professor, 2014, available online.

${ }^{147}$ As Mok as noted, “code provisions and recommended best practices are not mandatory rules.” See Mok, Thomas, Should The Hong Kong Code On Corporate Governance Practices Be Given Statutory Backing? Hong Kong Lawyer, Nov. 2014, at sec. 2, para. 2, available online.

148 See Bill To Protect Investors by Improving the Accuracy and Reliability of Corporate Disclosures Made Pursuant to the Securities Laws, and for Other Purposes [hereinafter Sarbanes-Oxley Act of 2002], at sec. 302, sec. 404, sec. 409, sec. 902 and sec. 906 respectively.
} 
include several very controversial issues which do not apply to Hong Kong. These include forming a board-level compensation committee, disclosure of compensation and introducing claw-back clauses into contracts which allow companies to take-back money paid to corporate executives who misstate financial results. ${ }^{149}$ More relevant for our discussion, the Act allows for law enforcement action in cases where corporate mis-governance which adversely affects the US. ${ }^{150}$ Hong Kong's government will need to find its own set of extra-territorial issues.

Our first recommendation centres on adding extra-territoriality of the Companies Ordinance and the Securities and Futures Ordinance. Such a provision should note that corporate governance obligations extend beyond Hong Kong and that companies may face extra-territorial sanctions if violated. For example, a new sec. 3(5) of the Securities and Futures Ordinance may not that the Ordinance does not only apply to Hong Kong, as allowed by law. A section 2(7) may make a similar reference. Given the novelty of extra-territoriality in Hong Kong, the provisions may signal the government's intent more than actually create the basis for effective enforcement. As the lawmakers and researchers gain experience with extra-territorial dimensions of Hong Kong's companies' foreign government practices, lawmakers may make these provisions more concrete and specific.

Our second recommendation deals with the corporate governance of non-listed companies. Our discussion has centered around listed companies - as most of the available research on corporate governance deals with such listed companies. Yet, as a signal of the government's intent to tighten corporate governance practices, the Companies Ordinance can raise awareness about corporate governance by requiring the dissemination of a code during non-listed company formation. Similar to the other declarations that promoters/directors must make under article 68 of the Companies Ordinance, they must declare that they have read - and will obey - the code. ${ }^{151}$ Such a declaration involving add two specific provisions. A new section 68.1(g) would require that the Companies Registrar disseminate a/the code of corporate governance with the incorporation documentation. A new section 70.1(c) would require that promoters declare they have read the code and intent to comply. Such a provision represents the first plank of a larger corporate governance reform policy.

Our third recommendation deals with the deterrence effect abroad of the SFC's work. As figure 36 shows, the Securities and Futures Commission has conducted relatively few investigations over the last four quarters. ${ }^{152}$ The SFC has encouragingly investigated poor governance practices. Yet, with so little detection of bad corporate governance practices at home in Hong Kong - the Commission looks unlikely to act as a corporate governance watchdog in the wider region. The small number of enforcement cases reported on the SFC's website (about 8 per month) would not

\footnotetext{
${ }^{149}$ Michael and Goo show that compensation does not represent a key corporate governance issue in Hong Kong. Banking represents the only place where these provisions might have a legitimate use (as disparities in banking compensation tend to follow international norms). See Kim, Hwa-Jin, Financial Regulation and Supervision in Corporate Governance of Banks, Journal of Corporation Law 41(3), 2016, available online.

${ }^{150}$ See Wu, Jennifer, Morrison v. Dodd-Frank: Deciphering the Congressional Rebuttal to the Supreme Court's Ruling, University of Pennsylvania Journal of Business Law 14(1), 2011, available online.

${ }^{151}$ Sec. 68.1.f in particular requires a statement of compliance as part of the content of the incorporation form. Sec. 70 describes the content of the statement. An amendment to Sec. 70 could/would mention the See Companies Ordinance, Chap. 622, available online.

${ }^{152}$ SFC, Investigations by nature, 2016 , available online.
} 
even appear legibly in the figure. ${ }^{153}$ Defining tougher, clearer and more credible punishments for violating corporate governance rules would help the SFC promote good corporate governance in the wider region.

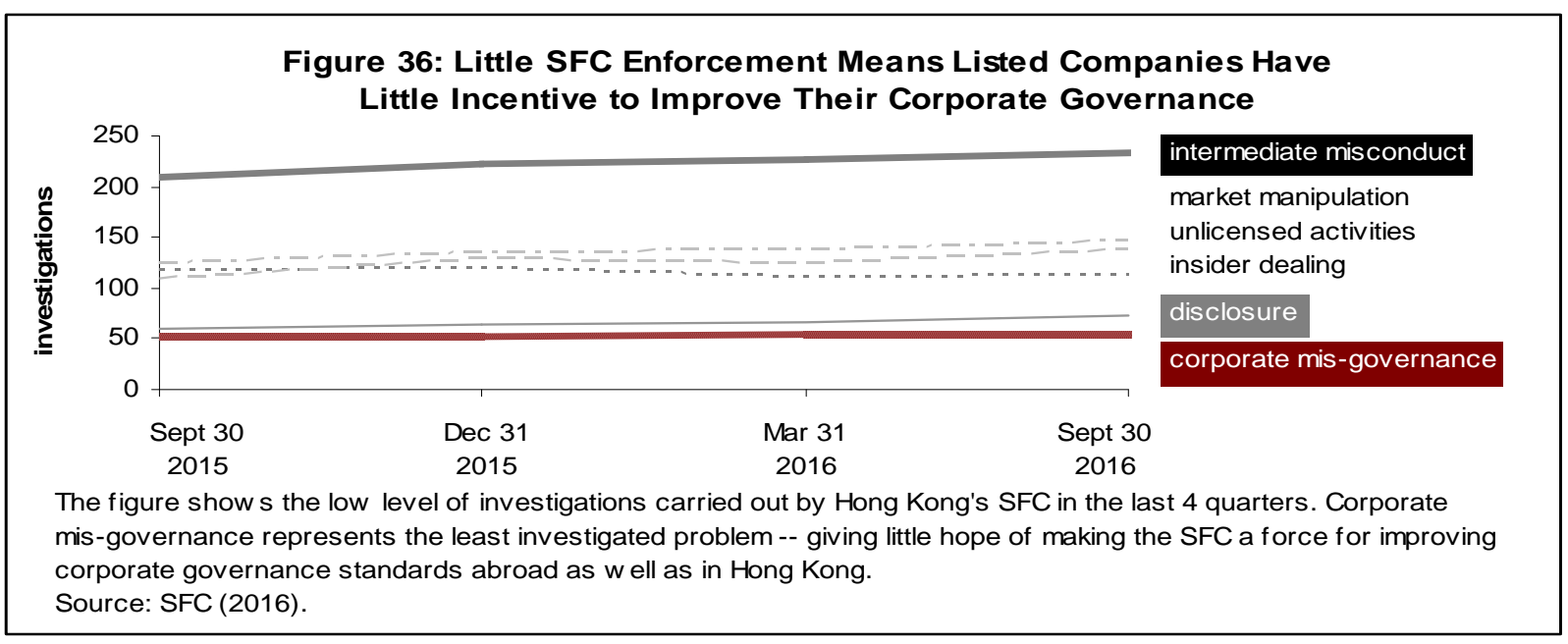

More specific punishments tied to compliance with the corporate governance code would clearly alter incentives. Figure 37 shows examples of the types of punishments lawmakers may opt for in seeking compliance with the code of corporate governance. ${ }^{154}$ Adding fines, civil and even criminal penalties would allow the SFC to fix the current toothless comply-or-explain regime. ${ }^{155}$ Foreign companies listing in Hong Kong would be able to give all kinds of unreasonable explanations without much fear of enforcement action taken against them. ${ }^{156}$ Further, when large scale or wide-spread fraud and other corporate governance failures surface, lawmakers tend to move corporate governance rules onto the law books - making a comply-or-explain system unstable in the long-run. ${ }^{157}$ Interestingly, Hong Kong's policymakers adopted the current system

\footnotetext{
153 SFC, Enforcement news, 2016, available online.

${ }^{154}$ For a detailed discussion of the ways Hong Kong's regulators, and especially the SFC, can implement such reforms, see Michael, Bryane and Say Goo, Last of the Tai-Pans: Improving the Sustainability of Long-Term Financial Flows by Improving Hong Kong's Corporate Governance, University of Hong Kong Faculty of Law Research Paper No. 2013/039, available online.

${ }^{155}$ Academics have generally found evidence showing the ineffectiveness of comply-or-comply regulation. In the UK context, see Arcot, Sridhar, Valentina Bruno, and Antoine Grimaud, Corporate Governance in the UK: Is the Comply-or-Explain Approach Working?, International Review of Law and Economics 30, 2010, available online. For more recent findings, see also Hadjikyprianou, George, The Principle of 'Comply or Explain' Underpinning the UK Corporate Governance Regulation: Is There a Need for a Change?, Corporate Law: Corporate Governance Law Journal 7(81), 2015, available online.

${ }^{156}$ Academics have quantified the large proportion of companies offering explanations which an independent observer would consider inadequate. Dealing with explanations of foreign companies, often in foreign languages, further decreases the likely usefulness of these explanations. For a description of how foreign culture complicates a comply-or-explain system, see Seidl, David, Paul Sanderson and John Roberts, Applying 'Comply-or-Explain': Conformance with Codes of Corporate Governance in the UK and Germany, Centre for Business Research University of Cambridge Working Paper 389, 2009, available online.

${ }^{157}$ As we have previously shown, the US best exemplifies the shift in corporate governance rules into the law books. Zadkovich, using Australia's experience, shows how lawmakers end up legislating corporate governance rules over time. See Zadkovich, John, Mandatory Requirements, Voluntary Rules and 'Please Explain': A Corporate Governance Quagmire, Deakin Law Review 12(2), 2007, available online.
} 
without any empirical evidence supporting comply-or-explain. ${ }^{158}$ Hong Kong should abandon the comply-or-explain approach to corporate governance which most empirical studies condemn as ineffective.

Figure 37: Possible SFC Remedies for Selected Corporate Governance Failures

\begin{tabular}{|c|c|c|}
\hline $\begin{array}{l}\text { Corporate } \\
\text { governance area }\end{array}$ & $\begin{array}{l}\text { Type of } \\
\text { punishment }\end{array}$ & Description \\
\hline A.1. Board & Fines & $\begin{array}{l}\text { Lack of regular board meetings denying certain directors a place at the } \\
\text { table could signal little oversight. Fines might discourage what is now a } \\
\text { all-gain-no-pain act. Such fines might also discourage marginal } \\
\text { conflicts of interest. }\end{array}$ \\
\hline $\begin{array}{l}\text { A.2 Chairman/ } \\
\text { CEO }\end{array}$ & $\begin{array}{l}\text { Facilitating } \\
\text { private action }\end{array}$ & $\begin{array}{l}\text { If the SFC documents lack of leadership by the chairman/CEO - and } \\
\text { makes shareholder redress easier - investors may help police markets } \\
\text { for corporate control. }\end{array}$ \\
\hline $\begin{array}{l}\text { A3. Board } \\
\text { composition }\end{array}$ & Fine & $\begin{array}{l}\text { Appointing independent non-executive directors is a mechanical task } \\
\text { which no company should have an excuse for overlooking. }\end{array}$ \\
\hline A4. Appointments & Fine & $\begin{array}{l}\text { Each point in this section is easy to monitor. Having fines may } \\
\text { encourage compliance audits to catch problems before they escalate to } \\
\text { the regulatory level. }\end{array}$ \\
\hline $\begin{array}{l}\text { A5. Nomination } \\
\text { Committee }\end{array}$ & Fine & $\begin{array}{l}\text { Again, a relatively mechanical task without any clear link to harms (thus } \\
\text { making civil remedies untenable). }\end{array}$ \\
\hline $\begin{array}{l}\text { A7. Access to } \\
\text { information }\end{array}$ & Civil & $\begin{array}{l}\text { Keeping certain directors in the dark could harm minority interests (for } \\
\text { example) or expose the company to risks. The SFC would play a role in } \\
\text { ensuring public disclosure of any lack of access to information, so } \\
\text { directors and shareholders themselves could seek redress. }\end{array}$ \\
\hline B.1 Remuneration & Civil & $\begin{array}{l}\text { Paying too much (or too little) for a senior executive could exhaust } \\
\text { shareholder funds and reduce profitable investment. Directors failing to } \\
\text { use a compensation committee put others' interests at risk - leading to } \\
\text { potential claims. }\end{array}$ \\
\hline C.1 Accounting & Criminal & $\begin{array}{l}\text { Directors could bear US-style criminal liability for checking and } \\
\text { ensuring accounting statements and discussion. The SFC would clearly } \\
\text { need to police these kinds of arrangements. }\end{array}$ \\
\hline \multicolumn{3}{|c|}{$\begin{array}{l}\text { The figure shows the possible remedies to breaches of the Appendix } 14 \text { of the Listing Rules which lawmakers could } \\
\text { include in the Securities and Futures Ordinance. Besides the light, existing remedies imposed by the Exchange (such } \\
\text { as delisting), other punishments could improve incentives for good corporate governance. Michael and Goo (2014) } \\
\text { discuss at length ways of encouraging investors and directors to use arbitration and courts to seek redress for the } \\
\text { harms that poor corporate governance causes. }\end{array}$} \\
\hline
\end{tabular}

${ }^{158}$ Numerous studies look at the UK's comply-or-explain rules. Yet, we could not find one empirical, econometric study looking at the effectiveness of Hong Kong's comply-or-explain rules. Hong Kong uses consultation papers as a key source of "empirical" evidence. For the recent consultation results on comply-or-explain, see HKEx, Consultation Conclusions Review of the Environmental, Social and Governance Reporting Guide, 2015, available online. 
Recommendation 1: Add extra-territoriality to the Companies Ordinance (in a new sec. 2(7)) and Securities \& Futures Ordinance (in a new 3(5)), if even as signal of intent, covering key corporate governance provisions from the Listing Rules.

Recommendation 2: Add requirements in section 68.1(g) and a new article 70.1(c) of the Companies Ordinance to require the dissemination of a corporate governance code with incorporation documents as well as require senior company officials sign a declaration noting that they have read the code and agree to follow the code.

Recommendation 3: Ditch comply-or-explain as well as add specific administrative, civil and criminal sanctions to the Securities and Futures Ordinance (if the SFC does not already have related rulemaking power) for violations of corporate governance provisions, as suggested in figure 37 of this paper.

What about China? Article 13 gives the central government in Beijing jurisdiction over foreign affairs - if extra-territoriality in itself (rather than in its effects) constitutes a "foreign affair."159 Article 17 gives the Standing Committee of the National People's Congress the power to reject any law it deems unconstitutional. Articles 8 and 18 clearly keep British law in place. Annex III does not cancel any laws with extra-territorial effect. As for China has its own extra-territorial laws, the central government should not consider the extra-territorial application of Hong Kong's corporate governance law as foreign to local legal jurisprudence. As one example of such an extra-territorial rule, Shen and Watters have argued that Circular 698 applies tax policy extraterritoriality, as any transaction - even between foreign entities -- transferring interest in a Chinese company taking place outside of China still attracts tax. ${ }^{160}$ Therefore, the Mainland would be unlikely to hinder the extra-territorial application of Hong Kong's corporate governance - particularly as it has its own extra-territorial application of very limited parts of its own corporate governance law.

\section{Options for Limited Cross-Border Enforcement Cooperation}

As noted previously, Hong Kong can not adequately export stringent corporate governance rules to places like the Mainland through its Listing Rules. A number of authors wrongly argue that mergers and acquisitions represent an important vector in transmitting "better" corporate governance rules. ${ }^{161}$ For example, Kim and Lu argue that differences in corporate governance

\footnotetext{
${ }^{159}$ The Basic Law of the Hong Kong Special Administrative Region of the People's Republic of China, 1997, available online.

${ }^{160}$ Shen, Wei and Casey Watters, Is China Creating A New Business Order? Rationalizing China's Extraterritorial Attempt to Expand the Veil-Piercing Doctrine, Northwestern Journal of International Law \& Business 35(3), 2015, available online.

${ }^{161}$ We do not have the space to describe the problems with these studies. For readers interested in making up their own minds, see Martynova, Marina and Luc Renneboog, Spillover of Corporate Governance Standards in CrossBorder Mergers and Acquisitions, Journal of Corporate Finance 14(3), 2008, available online. See also Coffee, John, Racing Towards the Top?: The Impact of Cross-Listings and Stock Market Competition on International Corporate Governance, Columbia Law Review 102(7), 2002, available online. See also Chen, Yun , and Yuan-Qiong He, The Research on Impact of Dual Listing on Corporate Governance and Corporate Performance: Evidence from Chinese Dual Listed Companies, 2008, available online.
} 
actually drive M\&A activity - as firms from developed countries “cherry pick” fast growing firms located in jurisdictions with weaker corporate governance practices. ${ }^{162}$ Yet, their arguments - and authors writing with the same world-view -- put the proverbial cart before the horse. As we showed already, corporate governance drives listing and M\&A decisions far more than such listing and M\&A drive changes in corporate governance. Natural change/evolution will not lead to significant change in corporate governance on the Mainland without some external force.

At present, Hong Kong has very limited options for encouraging compliance with its stringent corporate governance rules abroad. Hong Kong and many of its trading/investment partners have signed on to an International Organization of Securities Commissions' Memorandum of Understanding (IOSCO MOU) promising to expand consultation and cooperation between national financial regulators. ${ }^{163}$ Yet, the Memorandum of Understanding only concerns the sharing of information - rather than facilitating tangible help in conduct investigations and enforcing rules across borders. The SFC can, for example, use the MOU to possibly collect evidence on corporate governance violations conducted outside of Hong Kong. Yet, if Hong Kong wanted to refer a corporate governance violation to the Mainland authority, nothing in the MOU requires that the Mainland government receive, or act on, such information. ${ }^{164}$ Thus, even if the extra-territorial application of Hong Kong's corporate governance rules has no appreciable effect on deterrence and enforcement, at least the Securities and Futures Commission would put online information related to the agreements the regulator has made with foreign regulators. ${ }^{165}$

Extending the US-based conduct-effect approach to international law, authors like Lanois might logically argue that Hong Kong thus may apply corporate governance law extra-territorially if violation of these laws significantly affected Hong Kong. ${ }^{166}$ The US's SEC has exercised discretion and good judgment when seeking to apply extra-territorial law - and any attempt in Hong Kong would likely (and similarly) require respecting foreign countries' sovereignty. ${ }^{167}$ Similarly to our point made earlier, such an application would encourage convergence in corporate governance regulations - as Mainland companies (for example) adapt to Hong Kong's corporate governance rules which might apply directly to them. ${ }^{168}$ If such a view is correct, Hong

\footnotetext{
${ }^{162}$ See Kim, Han and Yao Lu, Corporate Governance Reforms Around the World and Cross-border Acquisitions, Journal of Corporate Finance 22(1), 2013, available online.

${ }^{163}$ See International Organization of Securities Commissions, Multilateral Memorandum of Understanding Concerning Consultation and Cooperation and the Exchange of Information, 2002 (revised 2012), available online.

${ }^{164}$ Like usual, the SFC does not provide information on its specific adoption of the MOU. The only public evidence available proving that the SFC has signed on to the multilateral MOU comes from a one line statement its website. See also Securities and Futures Commission, IOSCO MMOU, 2016, available online.

${ }^{165}$ See Arner et al. outline the lack of SFC's lack of transparency and the unavailability of agreements which other official sources cite. See Douglas Arner, Douglas, David Donald, Say Goo, Wei-Xing Hu, Chen Lin, Bryane Michael, Frank Song, Wilson Tong, Cheng-Gang Xu, Dariusz Wojcik, Simon Zhao, Assessing Hong Kong as an International Financial Centre, University of Hong Kong Faculty of Law Research Paper 2014/012, 2014, available online.

${ }^{166}$ Lanois' arguments apply to the US. Yet, nothing in his discussion suggests that his princioples apply uniquely or exclusively to the US. Indeed, he notes later in the article that failing to enforce Sarbanes-Oxley abroad results in discriminatory (advantageous) treatment of foreign companies. See Lanois, Paul, Between a Rock and a Hard Place: The Sarbanes-Oxley Act and its Global Impact, Journal of International Law and Policy 5(4), 2007, p. 4:14, available online.

${ }^{167}$ Id at p. 4:13.

${ }^{168} \mathrm{Id}$.
} 
Kong authorities would not need to actually enforce these rules. The threat of extra-territorial enforcement of Hong Kong's corporate governance rules would encourage firms in the Mainland and elsewhere to adopt changes to their local law which they already comply with in any case. If Hong Kong's authorities helped the foreign jurisdiction with investigating and/or prosecuting serious corporate governance violations, such assistance would help that foreign jurisdiction improve its own abilities to enforce securities and corporate law. ${ }^{169}$ Extra-territorial application of Hong Kong's corporate governance rules would encourage jurisdictions like the Mainland to adopt more stringent corporate governance rules. ${ }^{170}$

What legal instruments might Hong Kong rely on in policing the conduct and effects of poor/harmful corporate governance practices across borders? Mann and Berry describe the ways regulators cooperate to enforce securities and corporate laws abroad ${ }^{171}$ They claim that requests under the Hague Convention, mutual legal assistance treaties, and bilateral/ multilateral memoranda of understanding among regulators serve as the basis for enforcing rules (including corporate governance rules) across borders. ${ }^{172}$ Under the Hague Convention, the relevant authority in Hong Kong may send the relevant regulatory or court decision to the foreign equivalent of our Chief Secretary for Administration. The Foreign Judgments (Reciprocal Enforcement) Ordinance - and in the Mainland's case, the Mainland Judgments (Reciprocal Enforcement) Ordinance and especially section 21 - provide for sending Hong Kong's requests to foreign authorities for enforcement. ${ }^{173}$ Hong Kong already has such agreements with most of the governments in the region. ${ }^{174}$ The lack of cross-border enforcement shows that these agreements do not provide an adequate basis for international cooperation.

What would Hong Kong's limited extra-territorial application of its corporate governance rules look like? Hong Kong's proposed extra-territorial enforcement would, in practice if not in letter, not go as far as US enforcement in so-called "F-squared" and F-cubed" cases. ${ }^{175}$ Indeed, the US

\footnotetext{
${ }^{169}$ For evidence, see Carvajal, Ana and Jennifer Elliott, The Challenge of Enforcement in Securities Markets: Mission Impossible? IMF Working Paper 09/168, 2009, available online.

${ }^{170}$ We have observed such convergence as "ripple effects" (in Vakkur and Herrera-Vakkur's language) when the US adopted both the Sarbanes-Oxley and Dodd-Frank extra-territorial measures. For the econometrics behind foreign adoption, see Vakkur, Nicholas and Zulma Herrera-Vakkur, Ripple effects: Sarbanes Oxley's Impact Upon Investor Risk in a Global Economy, Review of Accounting and Finance 11(2), 2012, available online.

${ }^{171}$ See Mann, Michael and William Barry, Developments in the Internationalization of Securities Enforcement, International Law 39, 2005, available online.

${ }^{172}$ We vehemently disagree that "on a worldwide basis, securities regulators have developed a successful, multifaceted approach to the challenges posed by the internationalization of the world's securities markets" (Id at p. 668). Our discussion provides suggestions for achieving such internationalisation.

${ }^{173}$ We do not provide a detailed background on these ordinances in order to focus more on future cooperative arrangements. See Foreign Judgments (Reciprocal Enforcement) Ordinance, Chapter 319, available online. See also Mainland Judgments (Reciprocal Enforcement) Ordinance. Chapter 597, available online.

${ }^{174}$ Indeed for the OECD, these memoranda of understanding represent the way of promoting enforcement across borders. For a list of these cooperative agreements, and the strategies for pursuing cross-border collaboration on the enforcement of corporate governance-related law, see Fianna Jurdant, Public Enforcement and Corporate Governance in Asia: Guidance and Good Practices, 2014, available online.

${ }^{175}$ For a relatively recent overview, see Coupland, Jennifer, A Bright Idea: A Bright-Line Test for Extraterritoriality in F-Cubed Securities Fraud Private Causes of Action, Northwestern Journal of International Law \& Business 32, 2012, available online. For a readable overview, see Hanusik, Thomas and Traci Rodriguez, I Don't Live in the United States, So How Can the SEC Sue Me? SEC Actions against a Foreign National Living Outside the United States, Bloomberg, 2008, available online.
} 
itself has started to back peddle on the use of conduct/effects tests - in favour of less capricious and arbitrary transactional tests. To mirror the US's recent thinking, Hong Kong courts would need to litigate cases involving corporate governance when the "purchase or sale of the security is made in the [Hong Kong] or whether the security in the transaction is listed on a [Hong Kong] stock exchange.” ${ }^{176}$ Yet, Hong Kong’s lawmakers would do well not to impose limits on such extra-territoriality. Authors like Beyea argue that the US Supreme Court's curtailment of such extra-territoriality undermined investor confidence - and thus investment. ${ }^{177}$ Extraterritorial application of US corporate governance rules has not led to disagreements, conflict or the abandonment of comity between countries. ${ }^{178}$ Indeed, at least in the financial sector, many companies working across borders may already expect to feel the impacts extra-territorial administrative decisions. ${ }^{179}$ Thus, once the Legislative Council adopts extra-territorial corporate governance measures, political and economic pressures may encourage further expansion of such extra-territoriality.

Our fourth recommendation stems from arguments made by various scholars that a company's agreement to list on a foreign exchange makes the company - and those who direct it - bound by the foreign law of the listing exchange's jurisdiction. Lanois makes the case poignantly - noting that the listing decision entails "implied consent" to submit to the courts of the jurisdiction where the company lists. ${ }^{180}$ In his analysis, he notes that, "securities laws are entitled to be applied extraterritorially when foreign issuers have agreed to submit to the jurisdiction of the country where they wish to be listed.... The extraterritorial application of a national law would hence result from a voluntary decision made by the foreign corporation." ${ }^{181}$ Legal scholars like Besmer see the basis for effective enforcement in these implicit - or explicit - companies' agreements to

\footnotetext{
${ }^{176}$ We have substituted the phrase Hong Kong for the United States, to draw the obvious parallel with our paper's subject. Such a formula thus preserves a presumption against extra-territoriality - particularly important in Hong Kong's context, whereas Hong Kong's Basic Law restricts the governments exercise of powers in international/foreign affairs.

${ }^{177}$ We do not wish to go into the details of US law. Suffice it to say that the US Congress, reacting to limits imposed by the Supreme Court, expressly sought the extra-territorial application of parts of the Dodd-Frank Act. Sections 929P(b) and 929Y represent the most important parts of that law. See Beyea, Genevieve, Morrison v. National Australia Bank and the Future of Extraterritorial Application of the U.S. Securities Laws, Ohio State Law Journal 72, 2011, available online. See also Painter, Richard, The Dodd-Frank Extraterritorial Jurisdiction Provision: Was It Effective, Needed or Sufficient?, Harvard Business Law Review 1, 2011, available online. See also U.S. Securities and Exchange Commission, Study on the Cross-Border Scope of the Private Right of Action Under Section 10(b) of the Securities Exchange Act of 1934 As Required by Section 929Y of the Dodd-Frank Wall Street Reform and Consumer Protection Act, 2012, available online.

${ }^{178}$ We have already reviewed the evidence. But Coffee provides fodder for readers interested in assessing the opposite view. See Shirley, Jonathan, International Law and the Ramifications of the Sarbanes-Oxley Act of 2002, Boston College International and Comparative Law Review 27(2), 2004, available online. See also Coffee, John, Extraterritorial Financial Regulation: Why E.T. Can't Come Home, Cornell Law Review 99(1259), 2014, available online.

$\frac{}{179}$ Nothing exemplifies the use of administrative remedies across borders like the SEC's administrative subpoena. See Betman, Ronald and Jonathan Law, The (Too) Long Arm of the S.E.C.: When a Foreign Employee of a U.S.Based Multinational Financial Services Client is Threatened with a Subpoena, Berkeley Business Law Journal 10, 2013, available online.

${ }^{180}$ See Lanois, Paul, Between a Rock and a Hard Place: The Sarbanes-Oxley Act and its Global Impact, Journal of International Law and Policy 5(4), 2007, at II.a, available online.

${ }^{181}$ Id at II.a para. 3.
} 
comply with listing regulations' rules and enforcement actions. ${ }^{182}$ What happens if the management of a company listing in Hong Kong explicitly sign contracts to be bound to Hong Kong law and enforcement actions (which might be the same or differ from those applied to domestic parties)? At the very least, listing companies' could signal their acceptance to comply with, and face punishment for violating, Hong Kong's corporate governance rules.

Our fifth recommendation notes that implementing such extra-territoriality in practice should begin with the Listing Rules themselves. Regardless of the SFC's of Hong Kong Stock Exchange's currently self-perceived capacity to implement corporate governance rules extraterritorially, the Listing Rules should note that the rules apply extra-territorially - possibly in Chapter 2 (under general principles) and again in the first section (The Code) of Appendix 14 (which presents the rules). ${ }^{183}$ Given the likely harms to small companies, enforcement would apply on the Main Board, but not the GEM. ${ }^{184}$ If the SFC acts like the SEC, such a declaration might even open the door for the SFC to provide beneficial ad hoc advice to foreign companies rather than simply acting only as bad cop. ${ }^{185}$ Thus changes to the Listing Rules can implement Lanois' view of listing as an implicit contract to fall under the jurisdiction of the stock exchange where the company lists. The corporate governance rules should require companies to sign contracts (statements) to fall under Hong Kong's extra-territorial jurisdiction. Such a move even if such contracts have no legal force in the foreign country's home jurisdiction - at least gives the SFC and other authorities a more solid basis for challenging corporate malfeasance. The previous recommendations aimed at changing the Companies Ordinance and the Securities and Futures Ordinance set the basis for these changes to Hong Kong's Code of Corporate Governance.

Recommendation 4: Make the implicit agreement to accept extra-territorial investigations and punishment explicit by amending the legislatively adopted Code of Corporate Governance to require Listed Companies to contractually agree to the terms and conditions of Hong Kong's corporate governance rules.

Recommendation 5: Add a phrase Chapter 2 article 2.07 and in the first section of Appendix 14 clearly signalling the intent to apply extra-territorially corporate governance related Listing Rules.

Why don't we provide more details? Would Hong Kong's extra-territoriality work like in the US? What powers would its law enforcement have abroad? We leave these questions unanswered. Politics will determine the existence and nature of any extra-territorial corporate governance policies. Simply writing extra-territoriality into Hong Kong's laws will require significant time and energy. Any more discussion of specifics would be pre-mature.

\footnotetext{
182 See Besmer, Veronica, The Legal Character of Private Codes of Conduct: More than Just a Pseudo-Formal Gloss on Corporate Social Responsibility, Hastings Business Law Journal 2, 2006, available online.

183 See HKEx, Rules and Guidance on Listing Matters, 2016, available online.

${ }^{184}$ As noted previously, econometric studies show that Sarbanes-Oxley negatively impacted on smaller firms, making such regulation and enforcement distortionary. See Iliev, Peter, The Effect of SOX Section 404: Costs, Earnings Quality and Stock Prices, Journal of Finance 65(3), 2010, available online.

${ }^{185}$ For a description of this overseas work by the SEC, see SEC, International Enforcement Assistance, 2016, available online.
} 


\title{
Hong Kong's Contribution to the Share-Price-Raising Transparency of China's Corporate Governance
}

\author{
Reforming corporate governance indicators and assessment
}

Assessment of corporate governance in Hong Kong and the Mainland represent more than just interesting data. Authors like Abbott and Snidal argue that governance systems have completely changed in recent years. ${ }^{186}$ Calling the new system Transnational New Governance, these authors argue that the onus of regulation and enforcement has moved from government agencies to the wider business sector and civil society. Yet, academics and others conduct these assessments on an ad hoc basis - jeopardizing their comprehensiveness and repeatability. ${ }^{187}$ Political concerns and the formality attached to official corporate governance peer reviews -- like those championed by the Financial Stability Board - distort the data too much to use in academic or policy settings. ${ }^{188}$ The Financial Stability Board has no apparent mechanism or funding source in place to ensure regular objective evaluation (ie. not simply asking government officials what they think about their jurisdiction's corporate governance rules). The OECD's review of corporate governance arrangements around the world represent an excellent starting point for evaluating corporate governance rules. ${ }^{189}$ Yet, these evaluations fail to gather information about the implementation and effects of these corporate governance rules.

Our sixth recommendation encourages the Financial Services Development Council to recommend an organisation to organise corporate governance peer reviews between governments in the region (and especially the Mainland) based on the OECD's Guidelines. Making such a proposal clearly falls into the Council's terms of reference to provide advice and formulate proposals for government agencies. ${ }^{190}$ One possible recommendation might involve the conduct of such an assessment with the OECD's Centre for Cooperation with Non-Members. ${ }^{191}$ The OECD has increasingly worked with regional institutions like the Asian Development Bank on corporate governance-related dialogue and meetings for the better part of a decade. ${ }^{192}$ No matter what form that cooperation takes, such assessment will likely fail without adopting our seventh recommendation. Our seventh recommendation suggests adding to the Listing Rules the

\footnotetext{
${ }^{186}$ See Abbott, Kenneth and Duncan Snidal, Strengthening International Regulation through Transmittal New Governance: Overcoming the Orchestration Deficit, Vanderbilt Journal of Transnational Law 42, 2009, available online.

${ }^{187}$ For one example of such an assessment, see Yan Leung-Cheung and Hasung Jang, Scorecard on Corporate Governance in East Asia: A Comparative Study, In Choi, Jay and Sandra Dow (ed.) Institutional Approach to Global Corporate Governance: Business Systems and Beyond 9, 2008, available online.

${ }^{188}$ The "assessment" consists of asking government officials from each jurisdiction what they think about the various corporate governance rules in place in their jurisdiction. For more on the Financial Stability Board's intention to engage in such corporate governance peer review, see FSB, FSB launches peer review of the G20/OECD Principles of Corporate Governance and Invites Feedback from Stakeholders, FSB Communication 19/2016, 2016, available online.

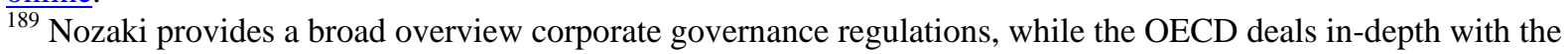
specific topics of related party transactions, takeover bids and shareholder meetings. See Nozaki, Akira, OECD Corporate Governance Factbook, 2015, available online. See also OECD, Supervision and Enforcement in Corporate Governance, 2013, available online.

${ }^{190}$ See Financial Services Development Council, About Us, 2016, at Terms of Reference, available online.

${ }^{191}$ See OECD, OECD Global Relations: Engaging with Non-Member Economies, 2016, available online.

${ }^{192}$ For background and information on the latest meeting, see OECD, OECD-Asian Roundtable on Corporate Governance, 2016, available online.
} 
requirement to publish enough information in corporate governance reports to allow for thirdparty assessment of corporate governance using the OECD Guidelines. Without the requirement to provide enough information publicly to do these assessments, assessment will likely stall as companies fail to share information out of concern for the public image and confidentiality.

Recommendation 6: The Financial Services Development Council should recommend an organisation to organise and set up procedures for corporate governance peer review between governments in the region (and especially the Mainland) based on the OECD's Guidelines or possibly under the aegis of the OECD's cooperation with non-member countries.

Recommendation 7: Add to the Listing Rules the requirement to publish enough information in corporate governance reports to allow for third-party assessment of corporate governance using the OECD Guidelines.

The most important tool at present for assessing corporate governance in the region consists of the Asian Corporate Governance Association's and CSLA's Corporate Governance Review. ${ }^{193}$ Figure 38 shows a sample of its latest rankings - from 2015. ${ }^{194}$ The organisation has published these assessments since 2003 - providing potentially comparative data for over 13 years. ${ }^{195}$ Such a track records beats hands-down other institutions, like the Asian Development Bank, which conducts one-off ad hoc assessments according to their popularity and funding. ${ }^{196}$ Even the IMF has not been able to assess China's corporate governance. ${ }^{197}$ The ACGA looks like the only sustainable organisation for conducting these kinds of assessments.

Figure 38: The CSLA-ACGA Corporate Governance Scores Provide a Possible Baseline for Future Assessments?

\footnotetext{
193 ACGA, Library - Regional Analysis - ACGA Reports, 2016, available online.

${ }^{194}$ See Jamie Allen, Asian Corporate Governance Association (ACGA) CG Watch 2014 - Market Rankings, 2015, available online.

195 The authors note several changes in definitions which hinder attempts to compare scores across years. We have not assessed such comparability in-depth, so we do not talk more about it. See CG Watch, 2003, available online.

196 At least they follow they mainly follow the OECD Principles. See Asian Development Bank, ASEAN Corporate Governance Scorecard: Country Reports and Assessments 2013-2014, available online. See also Asian Development Bank and ASEAN, ASEAN Capital Markets Forum, Corporate Governance Scorecard: Country Reports and Assessments 2012-2013, available online.

${ }^{197}$ IMF, Reports on the Observance of Standards and Codes (ROSC) Corporate Governance Program, 2016, available online.
} 


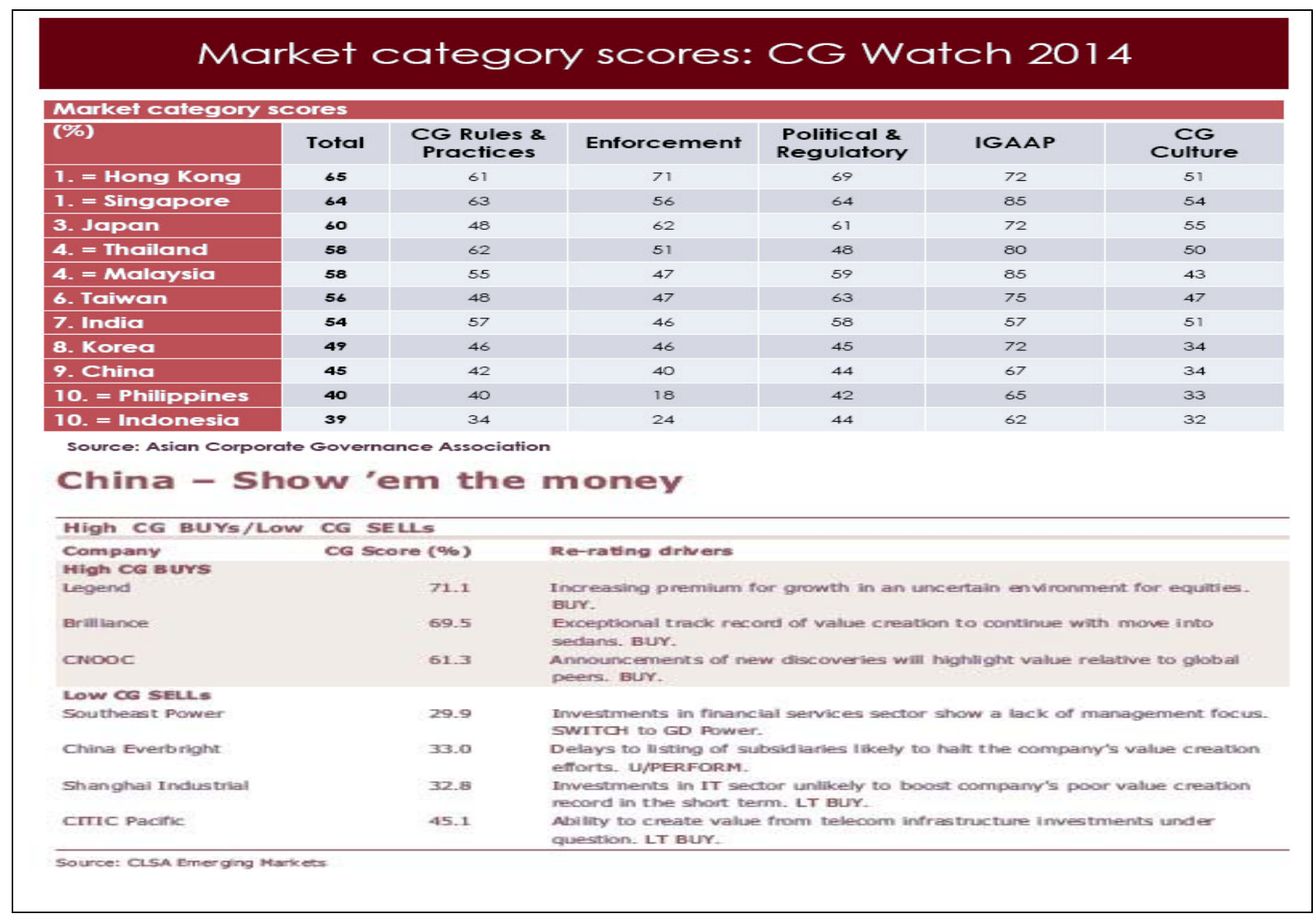

The Association's private sector funding provides a sustainable basis for these corporate governance assessments. The Asian Corporate Governance Association already has developed its own list of at least 111 organisational clients/members, ensuring a sustainable future. ${ }^{198}$ The Association claims 2,500 individual members. ${ }^{199}$ If true, these individuals could probably provide some in-kind support for assessing companies in their industries. In theory, the Association (ACGA) could work with companies in China and Hong Kong to implement internal corporate governance monitoring. A number of toolkits, like the International Finance Corporation's (IFC's) already exist for the ACGA to inexpensively draw on and use. ${ }^{200}$ The Shanghai Stock Exchange's abortive efforts at encouraging firms to evaluate their own corporate governance illustrate the importance of third-party evaluation. ${ }^{201}$ Hong Kong can exert crossborder influence on the Mainland's corporate governance by unilaterally marketing its assessments and sharing the results publicly.

\footnotetext{
198 ACGA, Members, 2016, available online.

199 Id at para. 1.

200 See IFC, Developing Corporate Governance Codes of Best Practice, available online. See also Volume 2:

Processes, available online. See also IFC, Supplement to Toolkit 2, Developing Corporate Governance Codes of Best Practice Assessing and Promoting the Implementation of Codes of Corporate Governance, 2014, available online.

${ }^{201}$ For more information on that attempt, see Shanghai Stock Exchange, Corporate Governance Self-Evaluation Form for Listed Companies in Shanghai, 2007, available online. See also Shanghai Stock Exchange, Assessment Methods for Corporate Governance Appraisal List for Listed Companies on the Shanghai Stock Exchange, 2007, available online.
} 
Before engaging in such assessment, the CSLA and ACGA will need to change their questionnaire to focus more clearly on issues identified by the international corporate governance community (like the OECD). As we previous illustrated, the OECD guidelines revolve around six areas -- the basis for an effective corporate governance framework, rights and equitable treatment of shareholders and key ownership functions, institutional investors, stock markets, and other intermediaries, role of stakeholders in corporate governance, disclosure and transparency and the responsibilities of the board. ${ }^{202}$ In contrast, the ACGA, using the CSLA questionnaire, organises their evaluation according to discipline (18\% weight), transparency (18\% weight), independence (18\% weight), responsibility (18\% weight), and fairness (18\% weight). ${ }^{203}$

Several examples illustrate the scope of the needed changes. Appendix 3 asks "does management stick to clearly defined core businesses?" 204 Another question asks whether the company “disclosed three- or five-year ROA or ROE targets?”205 The transparency part asks about publication in general - without discussing many specifics. ${ }^{206}$ The five questions in the responsibility section repeat some of the OECD Principles, with far less specificity. ${ }^{207}$ The last section basically asks whether "no controversy or questions [were] raised." 208 That being said, the ACGA provides a very good discussion of its questionnaire, and the statistical reasons for including or excluding certain questions. ${ }^{209}$ Yet, few organisations have discussed the data or the methodology, indicating a lack of linkage with the broader community of corporate governance experts. Involving more organisations' contribution to the questionnaire outside of ACGA can built support and perhaps increases its scientific value. ${ }^{210}$

The other issue relates to the CSLA's and ACGA's independence. Both organisations probably have several potential companies they would assess as clients. ${ }^{211}$ Judging by its 2012 report, most of the assessment seems to revolve around general market trends, with one or two companies' cases described as examples. ${ }^{212}$ Discussions of the 14 or so companies the report focused on contained 2-3 sentences, with information seemingly taken from the news. ${ }^{213}$ A quick overview of the report suggests that the sponsoring organisations do not practice favouritism vis-à-vis powerful companies. ${ }^{214}$ Yet, the incentives will always remain to provide assessments and consulting at the same time and to the same companies. Sponsorship from a market regulator

\footnotetext{
202 OECD, G20/OECD Principles of Corporate Governance, 2015, available online.

${ }^{203}$ CSLA and ACGA, CG Watch 2012 Corporate governance in Asia, 2012, at Appendix 3, available online

${ }^{204}$ Id at 1.

205 Id at 7.

${ }^{206}$ Id at $15-21$.

207 Id at 22-26.

208 Id 27-30.

${ }^{209}$ Id at Sec. 3.

${ }^{210}$ The Transparency International Corruption Perceptions Index represents an obvious example of such participation. With the World Bank's help, they involved leading academics and experts to revise the questions from the celebrated index. The index gained legitimacy from the exercise. See Kaufmann, Daniel and A. Kraay, Governance Indicators: Where Are We, Where Should We Be Going? The World Bank Research Observer 23(1), 2008. Several other studies look at the reliability of the index, showing the importance that academics and policymakers have placed in the index. See also Theresa Thompson and Anwar Shah, Transparency International's Corruption Perceptions Index: Whose Perceptions Are They Anyway?, 2005, available online.

${ }^{211}$ CSLA unsurprisingly does not disclose its clients.

212 CSLA and ACGA, CG Watch 2012 Corporate governance in Asia, 2012, at 69-73, available online.

213 Id at 75-76.

${ }^{214}$ Id at Figure 68 (China: Biggest CG gainers/decliners (alphabetical order)).
} 


\section{or market maker could significantly dull CSLA and ACGA's incentives to talk-up potential clients.}

The Hong Kong Stock Exchange (HKEx) represents the best choice of sponsor. Other institutions do not have the funding, interest in promoting market quality, and institutional support that the Exchange has. ${ }^{215}$ The HKEx earned HK\$8 billion in $2015 .{ }^{216}$ As shown in Figure 39, the HKEx also advertises at length its corporate social responsibility. If the HKEx supported the ACGA for \$1 million (roughly \$128,000 US) annually until the assessments became self-financing, such money should be enough to pay for the social goods aspects of its work. The Exchange has Community as a core value, as "help[ing] to build a sustainable community by supporting local initiatives that create effective and lasting benefits to the community." 217 The HKEx should not have the right to influence assessments and the funding should continue until they become selfsustainable. Certainly the Exchange could spare $1 / 8000^{\text {th }}$ its earnings to improve market quality at home and abroad.

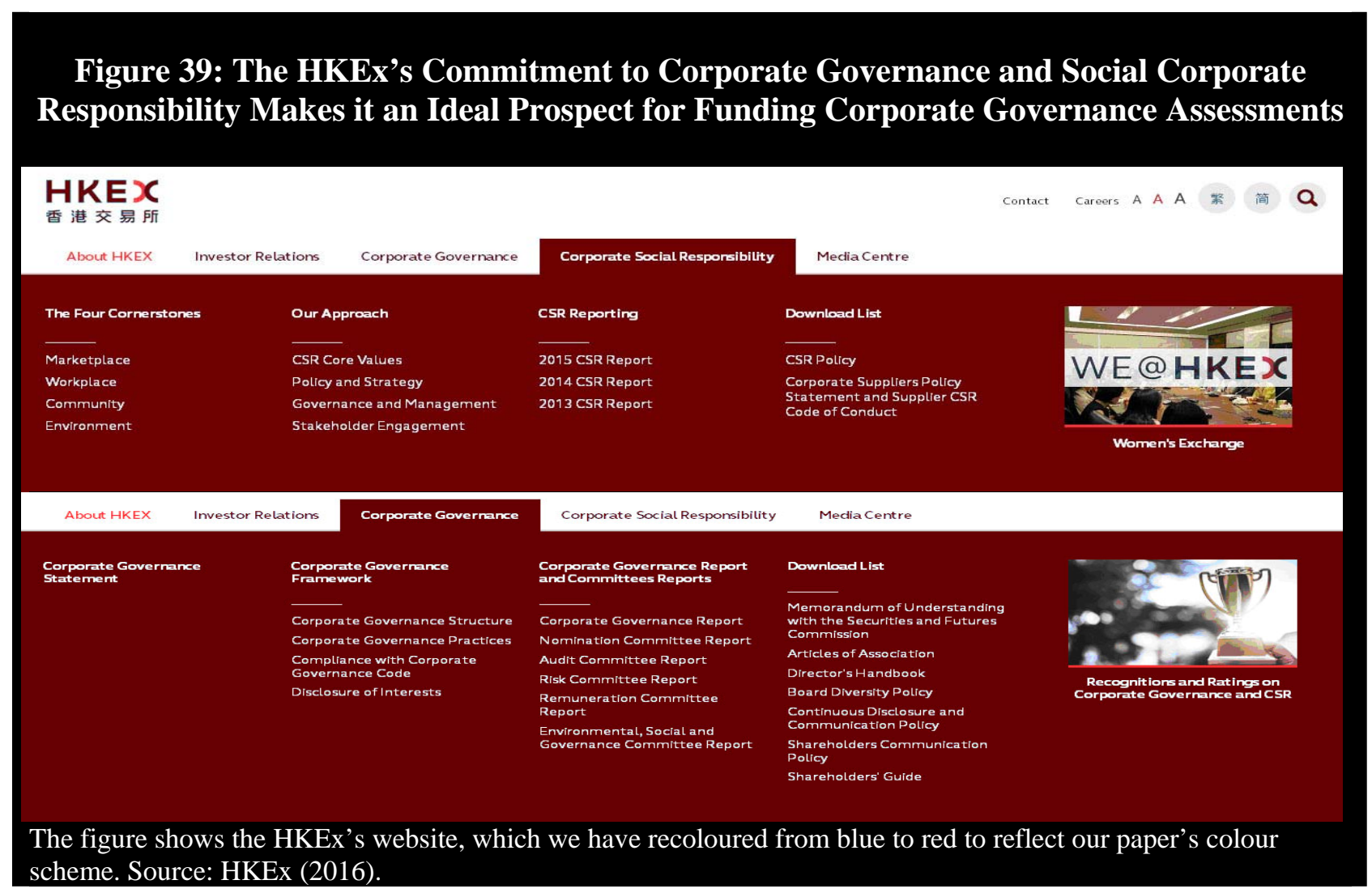

Our eighth and ninth recommendations thus relate to the Hong Kong Stock Exchange's cooperation on corporate governance assessments. The Exchange should open a dialogue with the Asian Corporate Governance Association (ACGA) and CSLA (its main supporter for these

\footnotetext{
${ }^{215}$ The Financial Services Development Council, research institutions at the local universities, and even the Company Register represent less desirable alternatives. In the case of the first two, they have no sustainable revenue source. In the latter, the conflict of interest obviously exists between register and assessor.

${ }^{216}$ HKEx, 2015 Annual Report, available online.

${ }^{217}$ Id at CSR Policy, 2016, available online.
} 
assessments) about sponsorship. The Exchange has enough clout to require changes to their assessment methodology to bring that methodology in line with international best practice. Sponsorship of roughly HK\$1 million per year can/should continue until these assessments become self-sustaining. The Exchange should also arrange for an internal audit of the assessment methodology and practice - to ensure that these assessments actually measure existing corporate governance practices.

Recommendation 8: Hong Kong Stock Exchange (HKEx) to start talks with Asian Corporate Governance Association (ACGA) and its funder CSLA , and allocate budgetary resources out of profits for, funding the publications their assessment criteria, data and work with business/academic community to ensure rigorous, comparable data.

Recommendation 9: Hong Kong Stock Exchange should provide HK\$1 million as part of its cooperation with the ACGA and CSLA (until financial independent) to conduct corporate governance monitoring contingent on modifying its assessment methodology to reflect OECD standards and an internal audit to ensure the integrity of its scoring process.

\section{Increasing Financial Transparency}

Numerous studies extol the virtues of corporate transparency (and particularly financial transparency) as a way to encourage better corporate governance - and visa versa. Regulations requiring greater disclosure not only benefit the companies themselves, but also the business environment in which they work. ${ }^{218}$ Authors like Laurence find that both individual and institutional investors actually do trade on the information disclosed. ${ }^{219}$ Chen et al. go further, looking at the extent to which poor disclosure and other corporate governance practices correlate with mis-investment (namely under or over investment as assessed by past, present and future revenues). ${ }^{220}$ As shown in Figure 40, alone, disclosure does not have a statistically significant effect on over or under-investment. Yet, disclosure does affect Mainland companies' corporate governance - which in turn affects investment. ${ }^{221}$ Increased disclosure when combined with better corporate governance seems to reduce over-investment - if increasing under-investment. Looking at the effects in well-governed Chinese firms shows a total decrease in investment inefficiency (namely the extent to which these firms over or under-invest). Market characteristics seem to have only microscopic effects on the extent of disclosure. Firms will disclose more before attracting external finance and when returns to assets rise. Disclosure decreases when market valuations increase and when a firm's management has more political connections.

\footnotetext{
${ }^{218}$ Choudhury in particular provides a balanced discussion of the legal issues involved in adopting such disclosure rules. See Choudhury, Barnali, Social Disclosure, Berkeley Business Law Journal 13(1), 2016.

${ }^{219}$ Lawrence, Alastair, Individual Investors and Financial Disclosure, Journal of Accounting and Economics 56(1), 2013, available online.

${ }^{220}$ Chen, Jean, Xin-Sheng Cheng, Stephen Gong, and You-Chao Tan, Voluntary Non-Financial Disclosure, Corporate Governance and Investment Efficiency, 2014, available online.

${ }^{221}$ The joint effect (ie interaction) between disclosure and corporate governance yields positive effects on underinvestment and negative effects on over-investment. One interpretation of these data might argue that such disclosure seems to cause boards to act more conservatively than otherwise.
} 


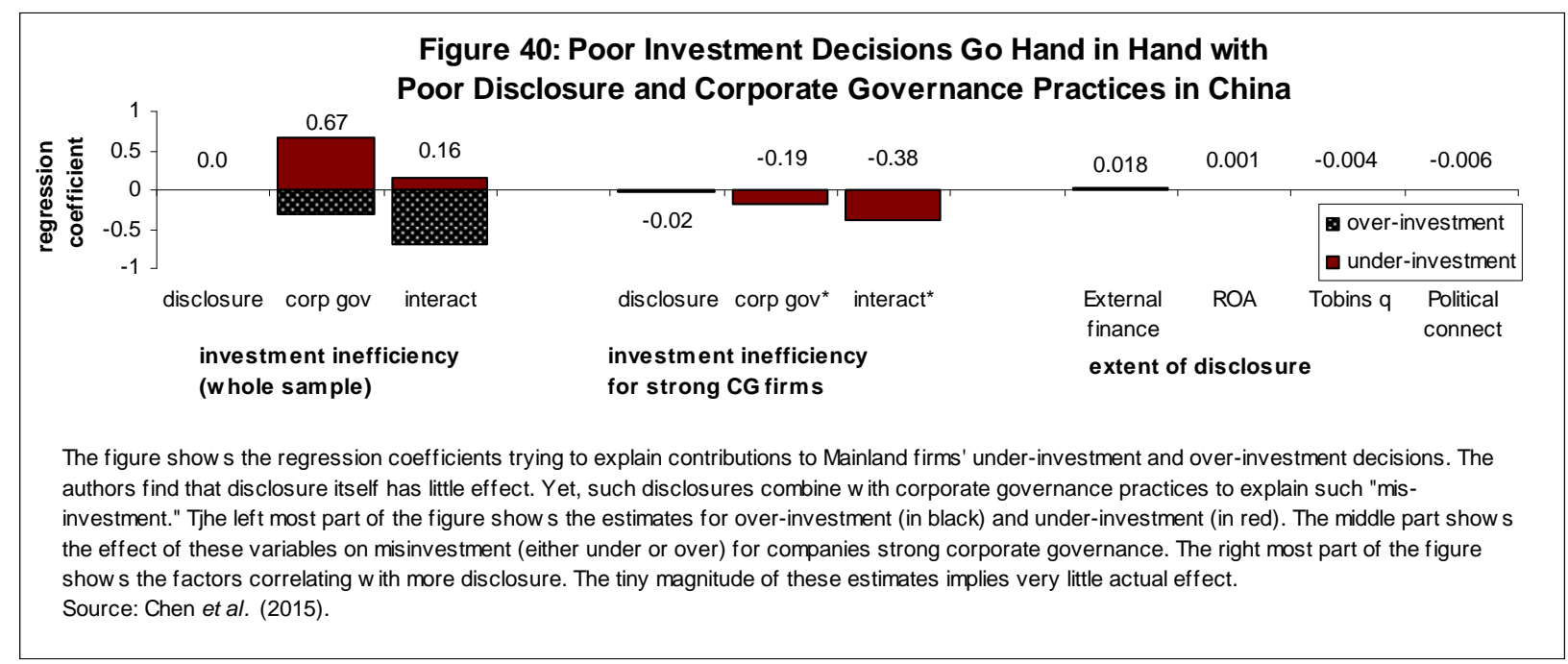

Despite these benefits, Mainland firms look unlikely to embrace greater transparency - even if the rules encourage them to do so. ${ }^{22}$ Figure 41 shows the improvement in various attributes of disclosure and corporate governance in Chinese (Mainland and Hong Kong) companies. ${ }^{223}$ On a five point scale, increases in corporate information barely score 2 out of 5. Disclosure comprehensiveness scores a bit less than 1, at a time when the Mainland's code of corporate governance had already been in force for five years. Yet, even with the most progressive rules (as illustrated by UK and German companies), companies do not voluntarily disclose more (or more relevant) information. Figure 42 shows the extent to which listed firms in the UK and Germany (as relatively progressive markets) comply with their corporate governance rules. ${ }^{224}$ Only around $70 \%$ of the very largest UK listed firms complied with that country's corporate governance rules. Many fewer of Germany’s largest listed companies complied with their version of corporate governance rules. Taken together these data show that simply “improving” corporate governance rules will likely have little effect on Mainland information disclosure.

\footnotetext{
${ }^{222}$ We do not have space to review these disclosure requirements. Readers interested in an in-depth discussion should see Fu, Jane, Corporate Disclosure and Corporate Governance in China, 2010.

223 See CFA Institute, China Corporate Governance Survey, 2007, available online.

${ }^{224}$ See Seidl, David, Paul Sanderson, and John Roberts, Applying ‘Comply-Or-Explain’: Conformance With Codes of Corporate Governance in the UK and Germany, University of Cambridge Centre for Business Research Working Paper No. 389, 2009, available online.
} 


\section{Figure 41: Little Improvement in Chinese Disclosure and Other Corporate Governance Measures Five Years After Mainland Code in Took Effect}

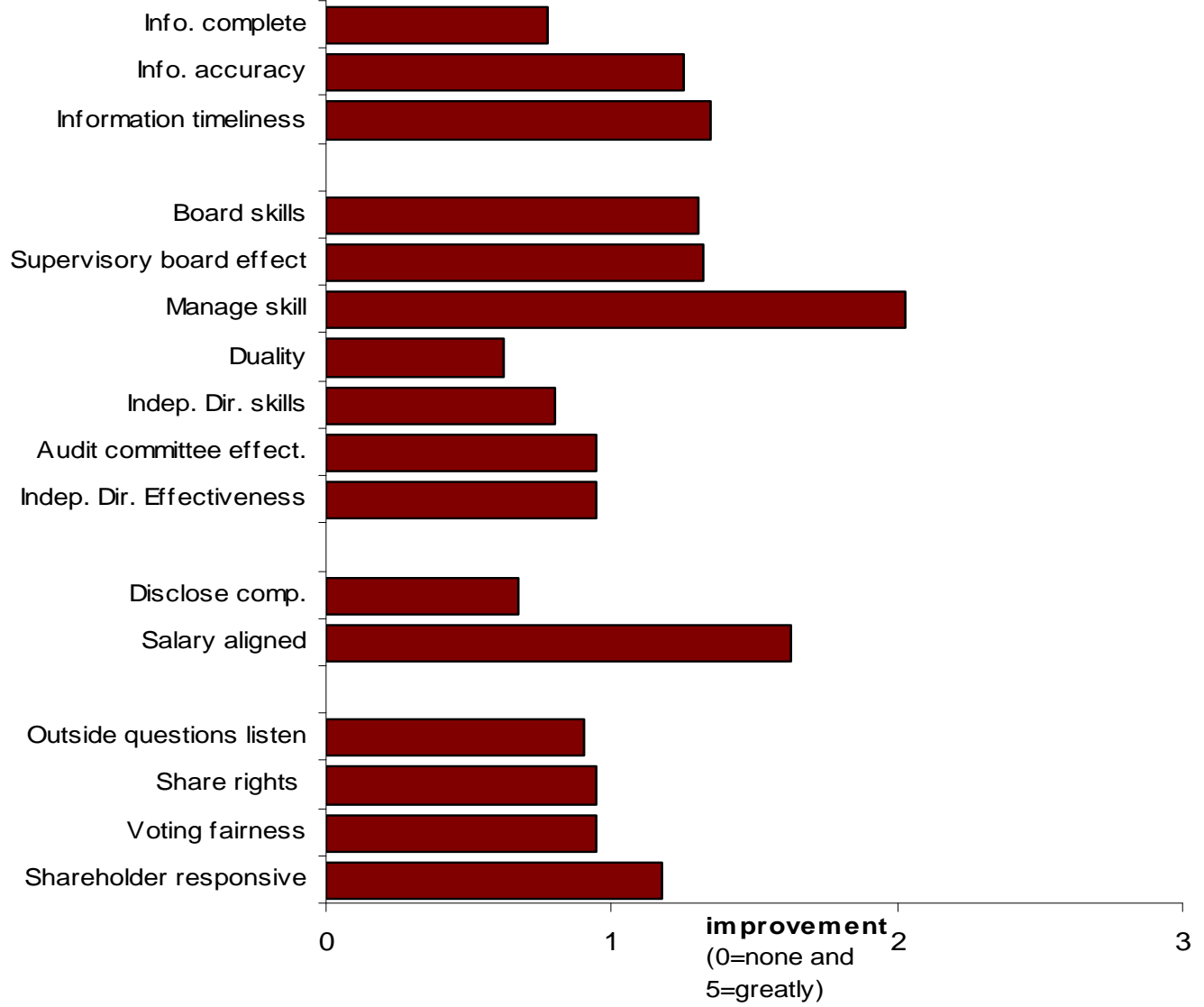

The figure shoms the improvernent in each of the corporate governance dimensions in the figure as assesed by 475 mermbers of the CFA Institute in Hong Kong and the Mainland. Relatively lirited improverments were made since the 2002 adoption of the Wainland's version of its code of corporate ' Governance. These results thus suggest that tightening the Mainland's own corporate governance rules may not have the desired effects.

Source: CFA Institute (2007).

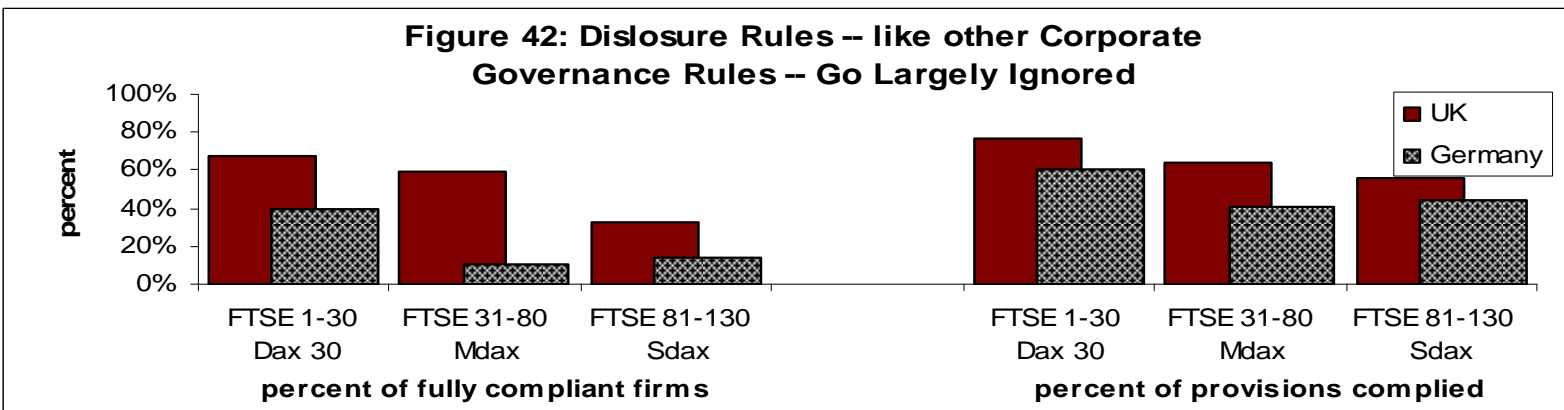

The figure show s the percent of companies complying $w$ ith -- and the percent of provisions complied with -- corporate governance rules for the tiers of the FTSE and Dax companies show n. German firms comply less than UK firms - show ing both the limits of comply-or-explain regulations and civil law jurisdictions ability to make them w ork.

Source: Seidl and Sanderson (2007). 
In the Middle Kingdom, government policy can actually direct firms against making disclosures. First, Chow notes more disclosure and better governance could actually cost managers their lives and freedom. ${ }^{225}$ The Communist Party uses politically motivated purges of companies and government bodies using the information obtainable from more open corporate reporting (as support for anticorruption investigations and prosecutions). In such an environment, no company has the incentive to freely disclose information. The government uses such opacity to conceal the real reasons for politically motivated prosecutions. Second, as Narine notes, disclosures rely on the company's stakeholders to act on these disclosures. ${ }^{226}$ The recent Sanlu case (of tainted milk) best illustrates how discretionary government involvement in corporate affairs on the Mainland make disclosure rules impossible to adopt and enforce. ${ }^{227}$ In that case, the government actively discouraged corporate executives from making disclosures that could have saved lives and investors money. ${ }^{228}$ With stakeholders unable or unwilling to act on information (due to government policy), the value within the country of such information remains questionable. Even wide-spread fraud among Mainland firms listed abroad has not led to any kind of domestic response on the Mainland - either for tighter rules as promulgated by the government or criticism from investors and other stakeholders. ${ }^{229}$ Indeed, disclosure remains at such a basic level as to hinder even researchers looking the extent of disclosure among Chinese firms. ${ }^{230}$

No tweak to Chinese companies' structure or market environment seems likely to produce large changes in corporate disclosures. Figure 43 shows the extent to which voluntary disclosure among Shanghainese listed companies depends on attributes like their size, profits, leverage and so forth. ${ }^{231}$ The size of the listed entity most dramatically affects such disclosure - as the firms' economic importance and resources available to provide such disclosures grow. Unsurprisingly, the number of independent non-executive directors on a board encourages such voluntary disclosure. Yet surprisingly, larger government shareholdings also correlate with more voluntary disclosure. Highly leveraged firms naturally do not embrace the disclosures which draw attention to their heightened financial risks. Yet, aside from these features - which in themselves do not have very strong influences - little affects the extent of these firms' disclosure.

\footnotetext{
${ }^{225}$ Chow, Daniel, How China's Crackdown on Corruption Has Led to Less Transparency in the Enforcement of China's Anti-Bribery Laws, U.C. Davis Law Review 49(2), 2015, available online.

${ }^{226}$ Narine talks about the effects of disclosure on human rights. Yet, her discussion is entirely general. See Narine, Marcia, Disclosing Disclosure's Defects: Addressing Corporate Irresponsibility for Human Rights Impacts, Columbia Human Rights Law Review 47(1), 2015.

${ }^{227}$ See Fu, Jenny and Geoffrey Nicoll, The Milk Scandal and Corporate Governance in China, Canberra Law Review 10(3), 2011.

${ }^{228}$ Id at p. 123.

${ }^{229}$ See McCarty, Janelle, Mergers \& Accusations: Chinese Auditing and Corporate Disclosure Standards Indirectly on Trial in the United States, Minnesota Journal of International Law 21(2), 2012.

${ }^{230}$ See Tucker, Jennifer and Xin-Min Zhang, Corporate disclosure and research opportunities in China, China Journal of Accounting Studies, 2016, available online.

${ }^{231}$ See Yuen, Desmond, Ming Liu, Xu Zhang, Chan Lu, A Case Study of Voluntary Disclosure by Chinese Enterprises, Asian Journal of Finance \& Accounting 1(2), 2009, available online.
} 


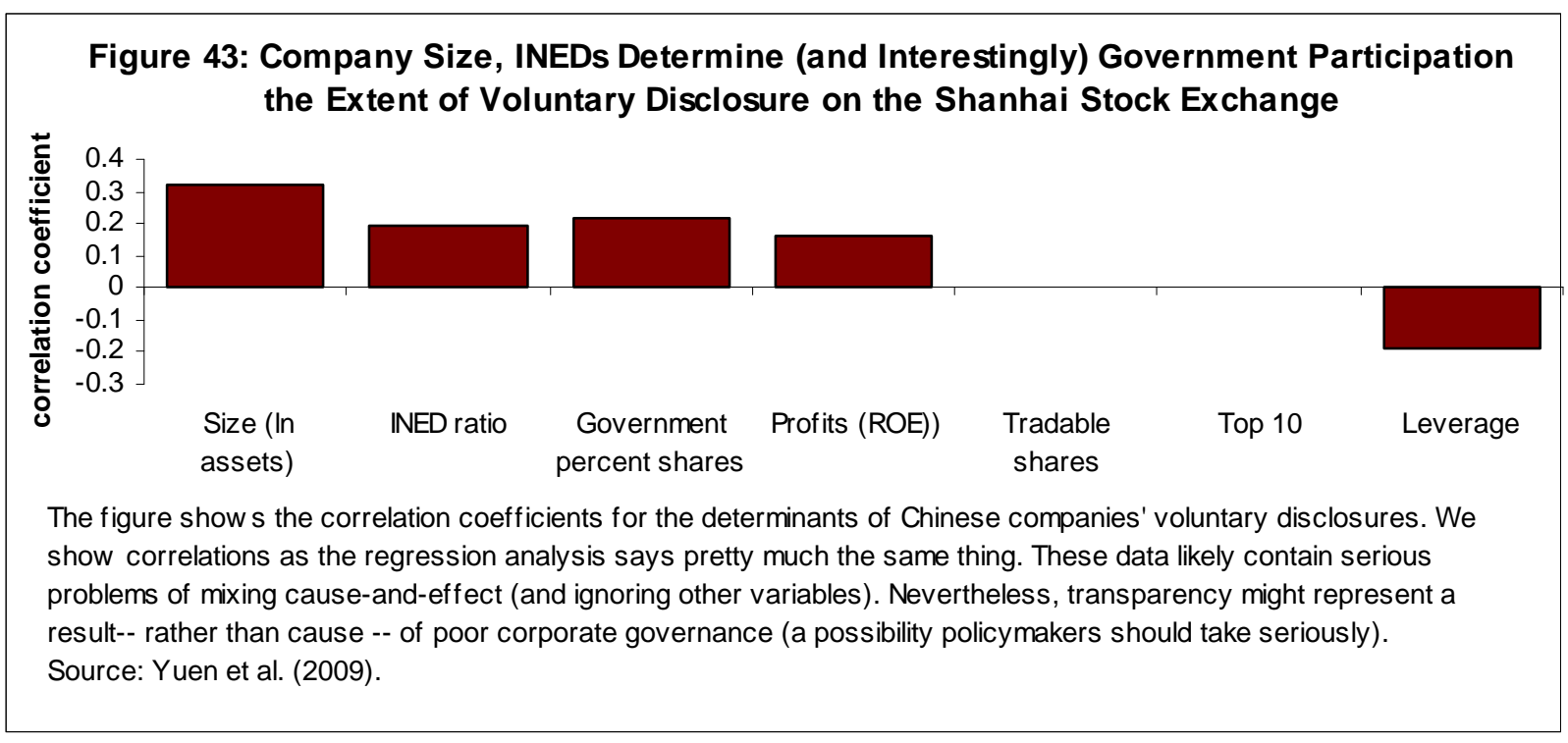

In such an environment, foreign oversight over Chinese firms' disclosure can add credibility and legitimacy to China's current disclosure system. In the Sanlu case mentioned above, the New Zealand government played an instrumental role in disclosing information about the tainted milk at a time when the central government tried to cover up the scandal. ${ }^{232}$ US listed Chinese companies' accounting irregularities came to light mainly because of a class action lawsuit in the US. ${ }^{233}$ In any case, cross-border work on requiring greater corporate disclosure appears to be the zeitgeist of our times. Section 1504 of the US's Dodd-Frank Act requires resource extractors abroad to disclose their payments abroad - a fundamentally extra-territorial rule. ${ }^{234}$ Authors like Lynn - echoing the language used in the legal draft -- refer to these extra-territorial rules as "specialized" disclosure rules. ${ }^{235}$ Firger more aptly refers to the new policy as "extraterritorial information-forcing." ${ }^{236}$ Extra-territorial rules will increasingly force companies to disclosure information their own governments do not require disclosed.

Stronger Hong Kong rules on disclosure could encourage Mainland firms to engage more profitable disclosure. Figure 43 shows the disclosure-producing effects of a foreign listing on

\footnotetext{
${ }^{232}$ For discussion, see Wishnick, Elizabeth, Of Milk and Spacemen: The Paradox of Chinese Power in an Era of Risk , Brown Journal of World Affairs 15(2), 2009.

${ }^{233}$ For more on these frauds and the way that US courts, rather than Chinese institutions, took the lead in remedying the situation, see McCarty, Janelle, Mergers \& Accusations: Chinese Auditing and Corporate Disclosure Standards Indirectly on Trial in the United States, Minnesota Journal of International Law 21(2), 2012.

${ }^{234}$ For more on its exact requirements, see Lynn, David, The Dodd-Frank Act's Specialized Corporate Disclosure: Using the Securities Laws to Address Public Policy Issues, Journal of Business \& Technology Law 6(3), 2011, available online.

${ }^{235}$ Id at p. 328. See The Dodd-Frank Act, sec. 1502 (on Specialized Corporate Disclosure), 124 Stat. at 2213-18. See also SEC, Specialised Corporate Compliance, 2016, available online.

${ }^{236}$ See Firger, Daniel, Transparency and the Natural Resource Curse: Examining the New Extraterritorial Information Forcing Rules in the Dodd-Frank Wall Street Reform Act of 2010, Georgetown Journal of International Law 41, 2010, available online.
} 
Mainland firms. ${ }^{237}$ Market valuations rise when Mainland companies disclose abroad presumably because foreign investors and stakeholders can act more effectively on these disclosures than those inside China. Probabilities of increased disclosure (including voluntary disclosure) jump very significantly when these Mainland firms list overseas. For authors like Li and Yang, increased disclosure builds constituencies for further disclosure - as the earnings quality improves as well as shareholder/analyst demand for disclosures increase. ${ }^{238}$ For authors like Myers and Steckman, increased transparency and disclosure serve to make Mainland corporate governance more self-enforcing. ${ }^{239}$ Thus, once such disclosure gains momentum in a place like Hong Kong, further transparency looks more likely.

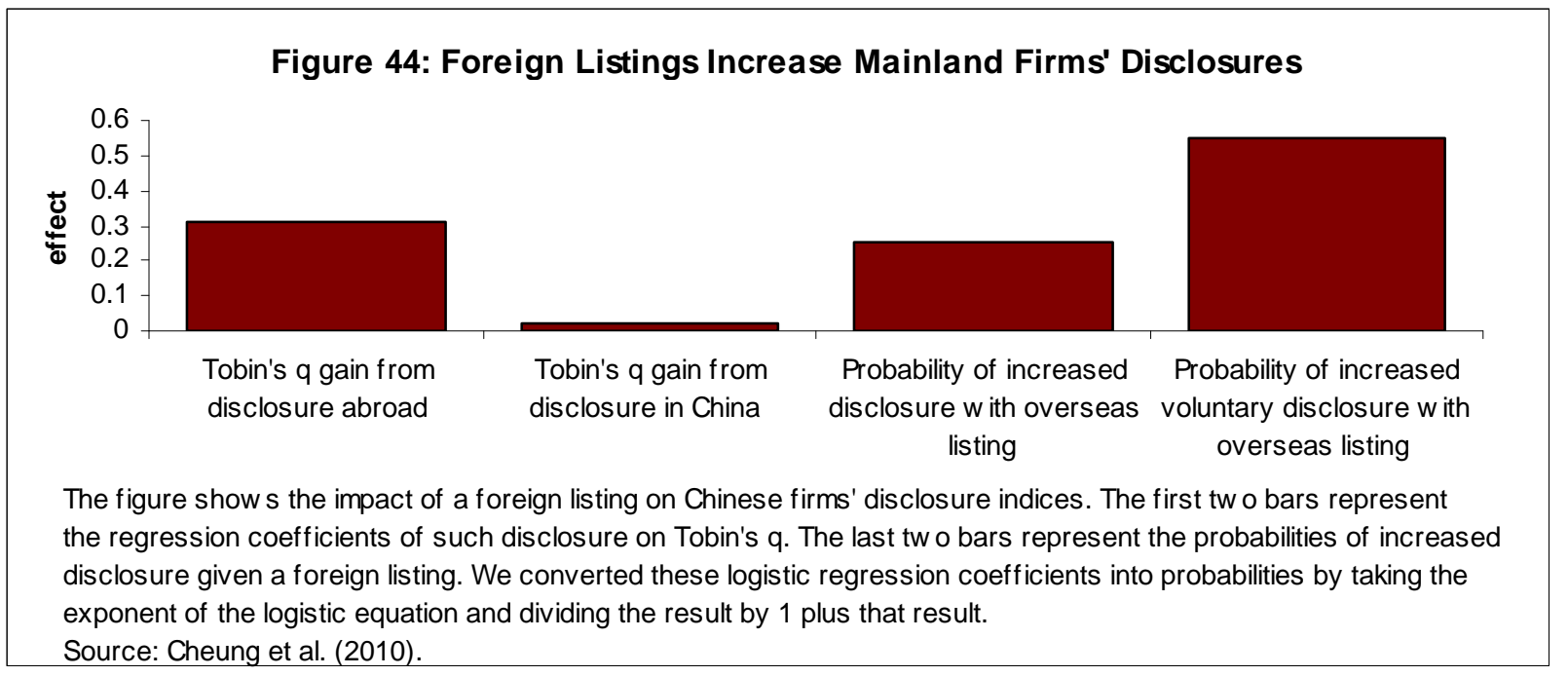

Several authors propose revolutionary legal changes which Hong Kong's common law system could support better than a civil law system. Siebecker argues that increased disclosure could result from expanding fiduciary obligations on corporate executives. ${ }^{240}$ Under the more expansive principle of "encapsulated trust", he would make corporate executive liable for breaches of their fiduciary duties to investors, consumers and others in failing to disclosure or disclosing inadequately financial and other information. Such "encapsulated" fiduciary responsibility would be completely foreign to the Chinese legal system. Thus, only the extraterritorial application of such a fiduciary principle would succeed. Even Enriques and co-authors' idea of letting each company decide its own optimal disclosure requires the flexibility of a system like Hong Kong’s. ${ }^{241}$

\footnotetext{
${ }^{237}$ See Cheung, Yan-Leung, Yan-Leung, Ping Jiang and Wei-Qiang Tan, A Transparency Disclosure Index Measuring Disclosures: Chinese Listed Companies, Journal of Accounting and Public Policy 29(3), 2010, available online.

${ }^{238} \mathrm{Xi}, \mathrm{Li}$ and Holly Yang, Mandatory Financial Reporting and Voluntary Disclosure: The Effect of Mandatory IFRS Adoption on Management Forecasts, The Accounting Review 91(3), 2016, available online..

${ }^{239}$ Myers, Thomas and Lawrence Steckman, Financial Transparency and Disclosure: China Progess on Corporate Governance, Journal of International Business Ethics 7(1), 2014, available online.

${ }^{240}$ See Siebecker, Michael, Trust \& Transparency: Promoting Efficient Corporate Disclosure through FiduciaryBased Discourse, Washington University Law Review 87(1), 2009.

${ }^{241}$ Enriques, Luca, Matteo Gargantini, and Valerio Novembre, Mandatory and Contract-Based Shareholding Disclosure, Uniform Law Review 15(3), 2010.
} 
Yet, at present, Hong Kong offers no shining example of disclosure and transparency for Mainland and other companies. Figure 45 shows Hong Kong's own scores for financial transparency (or lack thereof). ${ }^{242}$ As shown, Hong Kong ranks second worst among the jurisdictions polled for financial transparency. Hong Kong's unwillingness to sign up to several key international tax and anticorruption agreements represents on the key reasons for Hong Kong's poor rating. ${ }^{243}$ Hong Kong's large-scale overhaul of its money laundering rules probably makes part of this score too pessimistic. Yet, lack of signing up to key international transparency agreements represents a symptom rather than cause of secrecy. Behaviours typifying good corporate governance, like increased tax payments, increase as financial disclosures increase. ${ }^{244}$

\section{Hong Kong's lack of a disclosure culture in its corporate governance underpins most of the} reasons for Hong Kong's bad financial secrecy scores. ${ }^{245}$

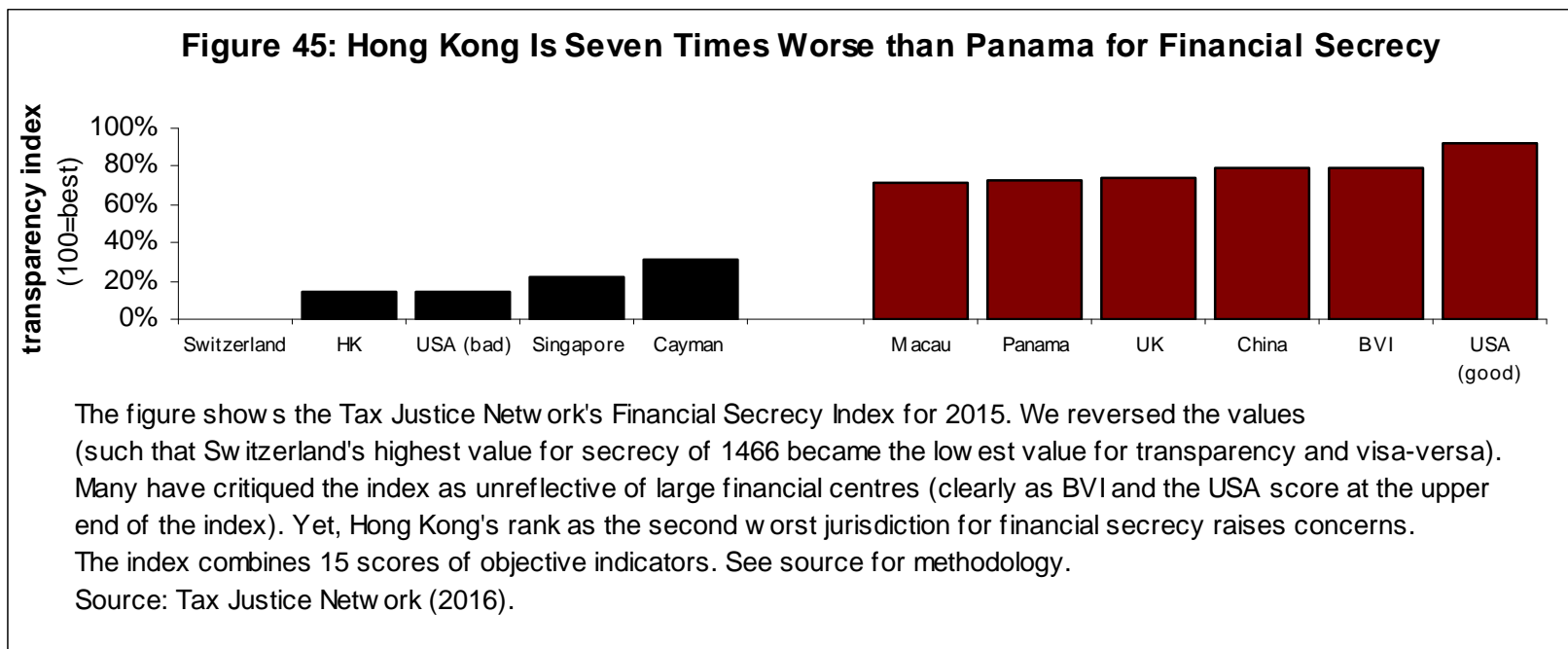

How can Hong Kong introduce a disclosure and transparency-based culture in a business system so antithetical to transparency in the past? Hong Kong businesses and business schools can undertake the changes that the UK and US have already undergone to mainstream transparency into management speak and perspectives. The US adjusted with its usual wave of management gurus and fads extolling the virtues of transparency. ${ }^{246}$ Consultants like PwC have already

\footnotetext{
242 Tax Justice Network, Financial Secrecy Index - 2015 Results, 2016, available online.

243 Signing on to international transparency commitments represents the $14^{\text {th }}$ out of the 15 key financial secrecy indicators assessed by the Tax Justice Network. For exact scores, see methodology, see Tax Justice Network, Financial Secrecy Index 2015 Methodology, 2016, available online.

${ }^{244}$ Gupta, Sanjay, Lillian F. Mills, and Erin Towery, The Effect of Mandatory Financial Statement Disclosures of Tax Uncertainty on Tax Reporting and Collections: The Case of FIN 48 and Multistate Tax Avoidance, Journal of the American Taxation Association 36(2), 2014, available online.

${ }^{245} \mathrm{Qu}$ and Leung illustrate with data the close connection between Chinese disclosure culture and how Chinese firms conduct corporate governance. As disclosure norms change, so should the governance practices encouraging disclosure. See Qu, Wen and Philomena Leung, Cultural impact on Chinese Corporate Disclosure-A Corporate Governance Perspective, Managerial Auditing Journal 21(3), 2006, available online.

246 Transparency cheerleading took place from the self-help management books to the panegyrics in Forbes and the other mainstream business media. See Tapscott, Don and David Ticoll, The Naked Corporation: How the Age of Transparency Will Revolutionize Business, 2003. See also Kirby, Julia, Trust in the Age of Transparency, Harvard
} 
profited from turning the transparency fad into sellable services. ${ }^{247}$ The UK has followed its consensual model - of having government coordinate the transparency effort. ${ }^{248}$ Given the importance of business groupings in Hong Kong, a pan-sectoral body like the Hong Kong Trade Development Council can/should cheerlead corporate transparency. Such cheerleading may include educating businesses about the benefits of transparency and disclosure. Such work may also consist of making industry standards and norms encouraging transparency according to each sector's own particularities. Most important, the relevant body can help reverse the presumption in most corporations that information should be concealed unless explicitly authorised to be publicly disseminated. ${ }^{249}$

This leads to our tenth recommendation. The Hong Kong Trade Development Council (or other suitable body) should endorse the right to information as a core value in companies' mission statements. By mainstreaming transparency in local business culture (as we showed empirically already), the business community will indirectly influence corporate governance practices at home and abroad. They should place particular emphasis on reverse the current presumption of confidentiality in Chinese business. Namely, managers and staff consider all information they produce or receive as confidential, unless explicitly instructed to publicise such information. If all companies agree to release information, no one company will find itself disadvantaged. And such a presumption of transparency will help reduce the extent of insider trading which devils Hong Kong's exchanges. ${ }^{250}$

Recommendation 10: The Hong Kong Trade Development Council (or other suitable body) should endorse the right to information as a core value in companies' mission statements as well as a "presumption of transparency."

Hong Kong’s Securities and Futures Commission also has a role to play in promoting disclosure and transparency. As we showed, recommendations like McCarty's to encourage the Mainland government to exercise more oversight and requirements for disclosure will not produce any results. ${ }^{251}$ The Mainland government continues to show an antipathy toward norms of transparency, even categorising certain commercial activities as state secrets. ${ }^{252}$ Harmonisation of

Business Review, 2012, available online. See also Patel, Neil, Why A Transparent Culture Is Good For Business, Fast Company, 2014, available online. See also Knapp, Alex, In The Era Of Transparency, Trust Is The Key To Success, Forbes, 2012, available online.

${ }^{247}$ PwC, Strengthen Trust and Transparency: Enhance Trust Across Your Network, 2016, available online.

${ }^{248}$ Department for Business Innovation and Skills, Transparency \& Trust: Enhancing the Transparency of UK Company Ownership and Increasing Trust in UK Business, 2012, available online.

249 Such a concept will not develop quickly. Even as late as 2014, the Hong Kong Institute of Certified Public Accountants was admonishing accountants and advisors to comply with even the minimums set by the Hong Kong corporate governance code. A new paradigm of openness seems light years away from their button-up analysis. See HKICPA, A Guide on Better Corporate Governance Disclosure, 2014, available online.

${ }^{250}$ Such a presumption would reduce the headaches associated with complying with new disclosure of inside information rules. For a discussion of those rules and the judgment calls involved, see CSJ, Disclosure of Inside Information - An Update, Journal of the Hong Kong Institute of Chartered Secretaries, 2015, available online. ${ }^{251}$ McCarty, Janelle, Mergers \& Accusations: Chinese Auditing and Corporate Disclosure Standards Indirectly on Trial in the United States, Minnesota Journal of International Law 21(2), 2012 at sec. 3.

${ }^{252}$ Mark, Liza, The Impact of Chinese State Secrecy Laws’ on Foreign-Listed Companies, Securities Regulation \& Law Report 46, 2014, available online. 
disclosure standards - and particularly IOSCO standards for foreign offerings, provide one way to encourage Mainland companies (and the Mainland's regulators) to adopt more open disclosure policies. ${ }^{253}$ Yet, such a checklist contradicts Hong Kong's increasingly principles-based regulation. ${ }^{254}$ One can read and adopt the standards mechanically, without thinking about the deep, underlying reasons for these standards. ${ }^{255}$ Yet, even once those financial instititutions and listed companies adopt those principles, analysts like Lu would have reforms of both the International Disclosure Standards and the IOSCO itself, as well as the IOSCO's conduct of "a corporate governance impact assessment.", 256 Thus, the adoption of a more transparency and disclosure centred business environment represents a globally accepted policy to which Hong Kong's policymakers could contribute substantially by encouraging such disclosure and transparency in business transactions "touching" Hong Kong.

The Securities and Futures Commission thus has five roles to play in promoting Hong Kong's eventual presumption-of-transparency culture. First, as noted in recommendation 11, the SFC could/should implement the spirit of the IOSCO principles, perhaps by issuing guidelines. Such guidelines, in conformance with Hong Kong's principles-based system, would offer practical ways of understanding the outcomes encouraged by such transparency. These guidelines should focus on the uses of more information by these companies' stakeholders (from investors to customers and even competitors). Second, the SFC can continue implementing the Financial Stability Board's and G20's recommendations on disclosure. ${ }^{257}$ Hong Kong's authorities have noted numerous "planned steps" in the disclosure action plan. "Industry consultation" and "monitoring international developments" should focus on the final users of information, instead of just pushing disclosure for disclosure's sake. Third, in line with its mandate to monitor firms' compliance with rules, including disclosure-related ones, the SFC should more actively assess and critique publicly lacking disclosure practices. Private markets and civil society has no incentive or resources to do such monitoring. Public censure also matches the objective of encouraging more transparency/disclosure - something in the regulator's own interest. Fourth, as noted in recommendation 12, the SFC's disclosure team could advice the users, as well as the producers, of disclosable information. At present, the team answers questions from listing companies about what information they need to give publicly. Yet, the users of such information far exceed the producers of such information. Their small and scattered nature reduces the incentives of any one information user from militating for more disclosure. By offering a resource to information users, the SFC could lower the costs of encouraging disclosure/transparency. The SFC would also receive vital feedback from the market about where informational bottlenecks exist. Fifth, as outlined in recommendation 13, the SFC could produce a booklet with advice for persons looking to pry information out of a company. Creating

\footnotetext{
${ }^{253}$ International Organization of Securities Commissions, International Disclosure Standards for Cross-Border Offerings and Initial Listings by Foreign Issuers, 1998, available online.

${ }^{254}$ As the SFC adroitly notes, "To address the fast changing market circumstances and practices, the Commission believes that, generally speaking, principles-based regulation that focuses on a higher level articulation of what the Commission expects intermediaries to do is more appropriate than a large volume of detailed standards.” See SFC, Regulatory Framework for Intermediaries, 2011, at point 29, available online.

${ }^{255}$ For example, standard IV.A.1 relates to collecting the "name, business experience, functions and areas of experience in the company." Such information clearly aids investors and analysts quickly understand the company. As such, the company should place the information in a prominent place with these readers/users in mind. See Id.

${ }^{256} \mathrm{Lu}$, Bing-Bin, International Harmonization of Disclosure Rules for Cross-Border Securities Offerings: A Chinese Perspective, Corporate Governance Law Review 1(2), 2005, available online.

${ }^{257}$ See Financial Stability Board, FSB- G20 Monitoring Progress - Hong Kong, 2011, available online.
} 
awareness about the harms and modes of redress for individuals deprived of some gain by the lack of disclosure/transparency helps build a constituency for transparency. ${ }^{258}$ Promoting transparency in Hong Kong can only encourage Mainland and other firms listing in this jurisdiction to act more transparently.

Recommendation 11: The SFC implements its ratification the IOSCO Principles of

Disclosure perhaps through a Guidance document), continue implementing the Financial

Stability Board's recommendations on disclosure and report publicly about the quality of firms’ disclosure practices.

Recommendation 12: Mandate the SFC's Corporate Disclosure Team to advise those looking for information (or complaining about a lack of information) as well as companies looking for information on disclosure.

Recommendation 13: The Securities and Futures Commission should produce a booklet advising persons harmed by a lack of disclosure/transparency and/or relying on such disclosures to recoup damages and complain about un-transparent practices.

Hong Kong's regulators and business can also encourage Mainland companies to follow on our exchange rules too difficult to adopt at home on the Mainland. $\mathrm{Xu}$ and $\mathrm{Xu}$ describe the travails of China's Open State Owned Enterprise (SOE) Information Bill. ${ }^{259}$ They argue that the public has an even larger right to information about SOEs, as the government and these SOEs work in the interests of the people. ${ }^{260}$ Their argument about access to information as a human right, as a way to lower social costs, and to reduce conflicts of interest in government might seem strange to western ears. ${ }^{261}$ Yet, their call for greater transparency echoes the same principles we have described. In a similar vein to the presumption-of-transparency we described earlier, the authors note only information sharing which harms the corporation and its interests should remain undisclosed - as "the bottom line should be defined: once information is disclosed to the public, the corporation will suffer substantial losses. For example, the proprietary knowledge of a corporation should not be disclosed because leaks in proprietary knowledge will provide the corporation's competitors with an obvious advantage." 262 Such a legal doctrine seems at odds with past SOE management in China. ${ }^{263}$ Nevertheless, as a contributor to the OECD guidelines on the corporate governance of SOEs, the government "Recognis[es] that state-owned enterprises

\footnotetext{
${ }^{258}$ This is a fluid and quickly changing part of the law in developed economies. Steinman for example provides a fascinating glimpse into a recent US case involving the issues of disclosure and harm. A digression about the role of regulatorily mandated disclosure, the estimation of harms from non or incorrect disclosure and judicial remedies would take us too far off topic. See Steinman, Joan, Spokeo, Where Shalt Thou Stand?, Vanderbilt Law Review 68, 2015, available online.

${ }^{259}$ We could not find any mention of the adoption of the proposed Act. We thus must rely on Xu and Xu's description. See Xu, Xue-Lei Xu and Xin Xu, Information Disclosure of State-Owned Enterprises in China, Tsinghua China Law Review 4(1), 2011, available online.

${ }^{260}$ Id at p. 4.

${ }^{261}$ Id. III.D.

${ }^{262}$ Id at p. 32.

263 Zhang, Dong and Owen Freestone, China's Unfinished State-Owned Enterprise Reforms, Australian Treasury Economic Roundup 2, 2013, available online.
} 
face some distinct governance challenges arising from the fact that their ownership is exercised by government officials on behalf of the general public."264 Thus, neither SOE managers nor the Communist Party should object to more open corporate governance and disclosure rules for Mainland state-owned enterprises.

Yet, the data show that the Mainland's SOEs need special rules and enforcement practices in order just to catch up with private sector firms. Figure 46 shows the percent of Chinese SOEs providing information about various aspects of their corporate existence and operations. ${ }^{265}$ Most state-owned enterprises disclose information about their organisational structure (though the extent to which they report on the exact structure...including relations with offshore entities...remains unknown). ${ }^{266}$ Reports about capital investment remain popular - as a way SOE executives can brag to the central government. ${ }^{267}$ If heavy industry continues to release news about its achievements, service, agricultural and even information technology companies have far less political and economic clout, as reflected in their lacklustre reporting. Only 9\% of companies provide information about their human resources. Lack of principles and purposes of transparency and disclosure make the SOE particularly ready for reform introduced from abroad.

\footnotetext{
${ }^{264}$ OECD, OECD Guidelines on Corporate Governance of State-Owned Enterprises, 2015, at p. 9 (Recommendation of the Council on Guidelines on Corporate Governance of State-Owned Enterprises), available online.

${ }^{265}$ See See Xu, Xue-Lei Xu and Xin Xu, Information Disclosure of State-Owned Enterprises in China, Tsinghua China Law Review 4(1), 2011, at p. 23, available online

${ }^{266}$ China's Going Out Policy further complicates matters - as these firms may have legitimate commercial interests offshore which represent more than simply incorporating shell companies in offshore fiscal paradises. See Chen, Duan-Jie, China’s State-Owned Enterprises: How Much Do We Know? From CNOOC to its Siblings? University of Calgary School of Public Policy Research Paper 6(19), 2013, available online.

267 The politics of investment often over-ride the economics of profit maximisation, making corporate governance far less necessary for these SOEs without a clear policy from the centre. See Leutert, Wendy, Challenges Ahead in China's Reform of State-Owned Enterprises, Asia Policy 21, 2016, available online.
} 


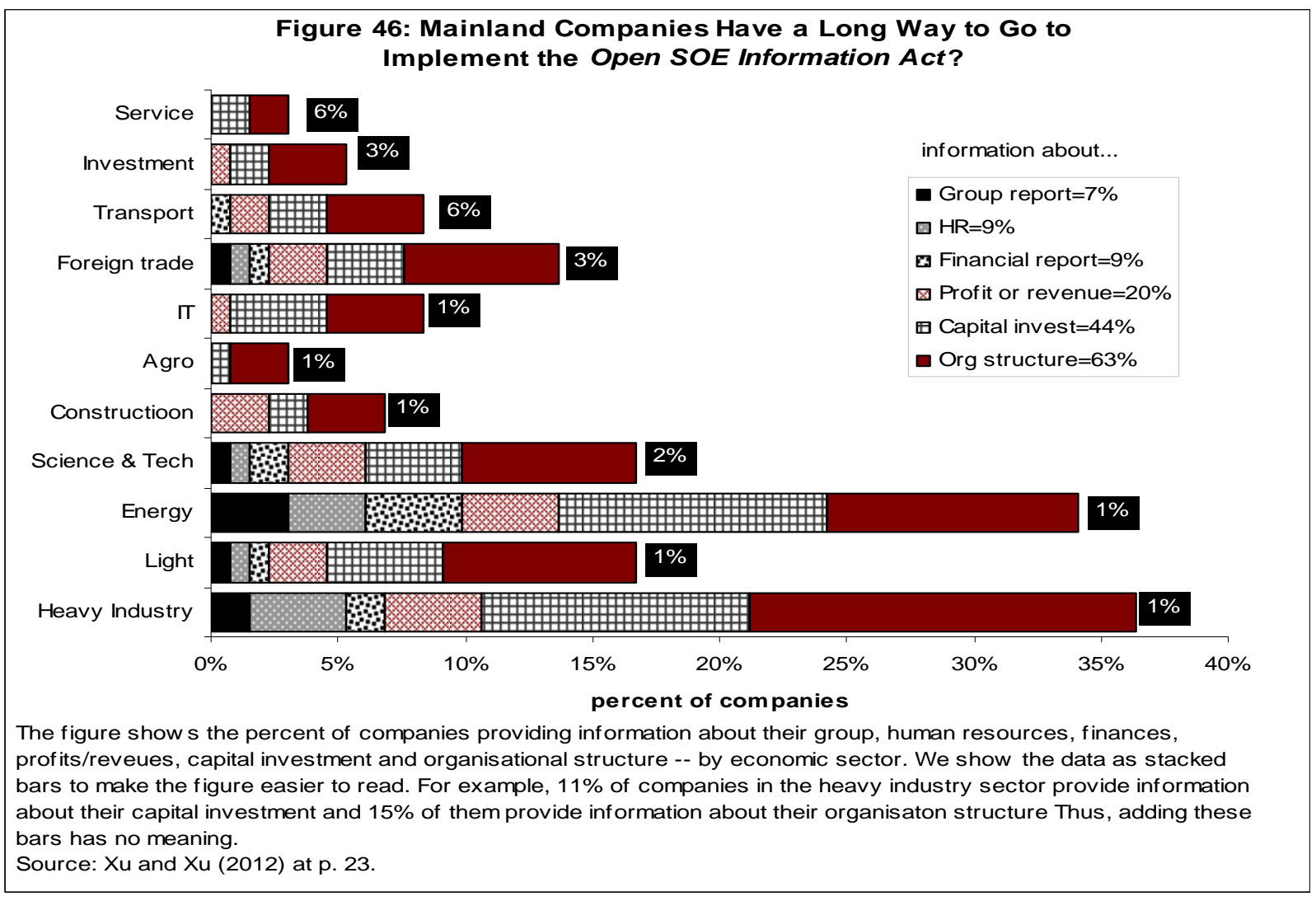

Our fourteenth recommendation thus concentrates on the way that Hong Kong's regulations can encourage Mainland SOEs to adopt pro-transparency reforms that have stalled on the Mainland. SOEs listing in Hong Kong can follow the draft Open SOE Information Bill and/or the OECD Guidelines for State-Owned Enterprises, as relevant. Again, because all SOEs must follow the same rules, extra disclosure should not necessary harm particular SOEs. To help with such disclosure, SOEs can adopt the OECD's advice on SOE transparency - particularly Chapter 5 describing how to draft and adopt an SOE disclosure and transparency policy. ${ }^{268}$ SOE managers can download such guidance for themselves. Yet, by providing them with copies of resource and supporting materials, the Hong Kong government can illustrate its dedication to improving market quality.

Recommendation 14: Unilaterally require the provisions of the Open SOE Information Bill (or the OECD Guidelines on Corporate Governance of State-Owned Enterprises as relevant) for state-owned Mainland corporates listed in Hong Kong.

Recommendation 15: Include the need to have an SOE disclosure and transparency policy as part of the disclosure rules for SOEs, and provide best practice guidance from the OECD or other qualified body.

${ }^{268}$ OECD, Accountability and Transparency: A Guide for State Ownership, 2010, available online. 


\section{Creating an Ultimate Beneficial Ownership Database}

The Mainland looks unlikely to create the beneficiary database which will encourage proper corporate governance. ${ }^{269}$ Figure 47 shows China's rating for the collection and transparency of beneficial ownership. ${ }^{270}$ As shown, China does not score too badly - certainly better than the USA. Yet, these ratings look dubious, even at first glance. According to two major surveys we consulted, Mexico and Russia (two jurisdictions often in the media for money laundering and a large black economy) score higher. Professor Henry estimates that offshore money sent from China (thus sitting in accounts offshore, whether declared or not) comes to around \$742 billion in 2000 US dollars (or about \$1 trillion in today’s money). ${ }^{271}$ Similarly, Hong Kong has about \$173 billion in current dollars floating around offshore. Hong Kong statistics show more than 7,000 companies set up in Hong Kong by Chinese nationals. Thus, only listing Mainland beneficial owners' interests outside of China would bring more than $\$ 1$ trillion into the light.

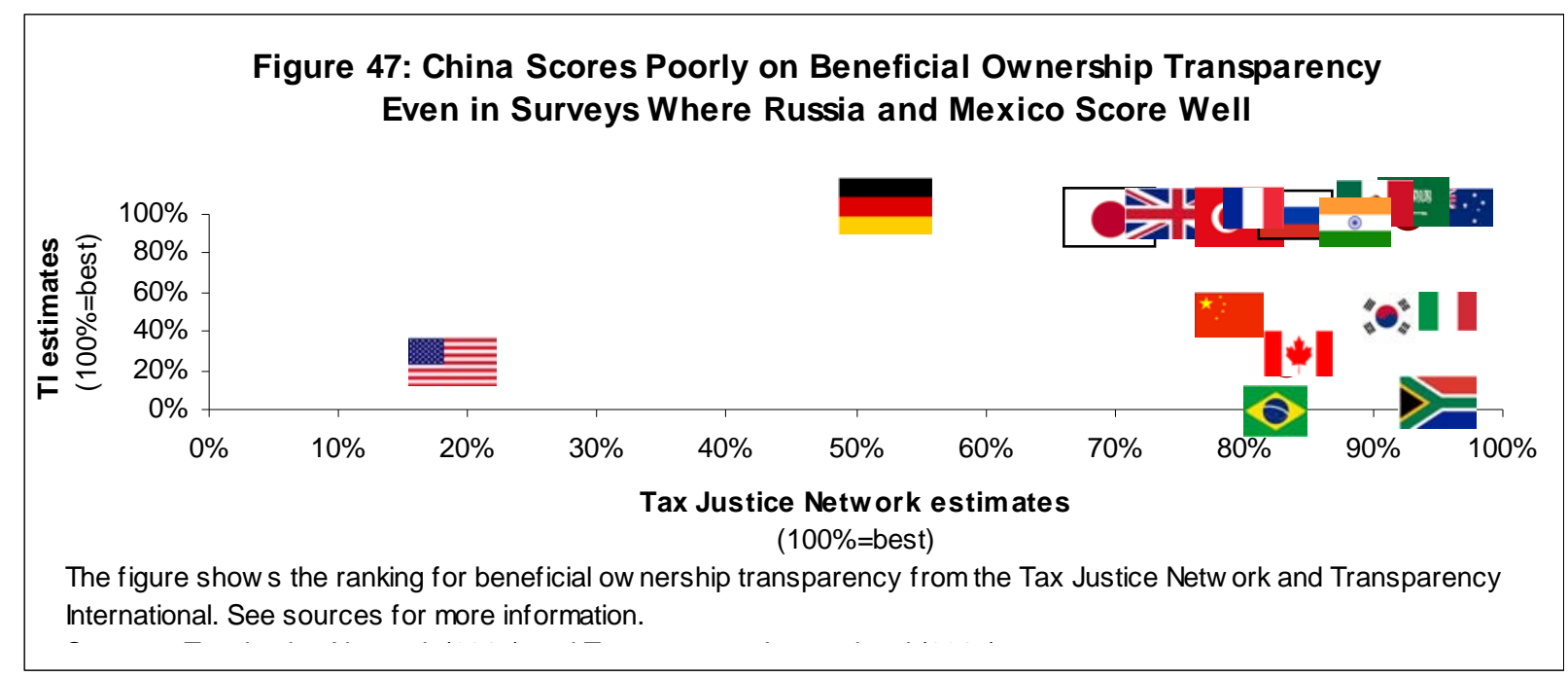

Having such data would help us (and the Mainland government) find relationships between ownership in corporate interests and the governance of these corporations. Fortunately, the European Union's rules on the declaration of such interests allow us to glimpse the type of analysis we could perform if ownership declaration came to Hong Kong and the Mainland. Figure 48 shows an example of the kind of analysis one could perform with data about ultimate beneficial ownership - albeit only in Europe. Companies with lower (worse) levels of corporate governance have Mainland owners who have accumulated relatively large blocks of these companies' shares. We would not expect to see such concentrated ownership - as the EU's

\footnotetext{
${ }^{269}$ The Tax Justice Network provides a pleasant, graphical overview of China's current compliance with best practice in the area of the reporting of beneficial ownership (and other activities intended to provide more transparency in its tax matters). See Tax Justice Network, Report on China, 2015, available online.

${ }^{270}$ See Martini, Maira and Maggie Murphy, Just for Show: Reviewing G20 promises on beneficial ownership, 2015, available online.

${ }^{271}$ Henry, James, The Price of Offshore Revisited: New Estimates for Missing Global Private Wealth, Income, Inequality, and Lost Taxes, Tax Justice Network Working Paper, 2012, available online.
} 
corporate law reduces the agency problems found on the Mainland. ${ }^{272}$ We also observe a clustering of firms - with large numbers of firms either having the best (maximum) value of corporate governance ...or the worst (minimum) amount. These data seem to confirm our own findings about the Panama Papers data. Corporate governance remains poor in Mainland firms (or firms with Mainland owners) until reform improves these companies' corporate governance practice enough to making more corporate governance reform desirable. ${ }^{273}$

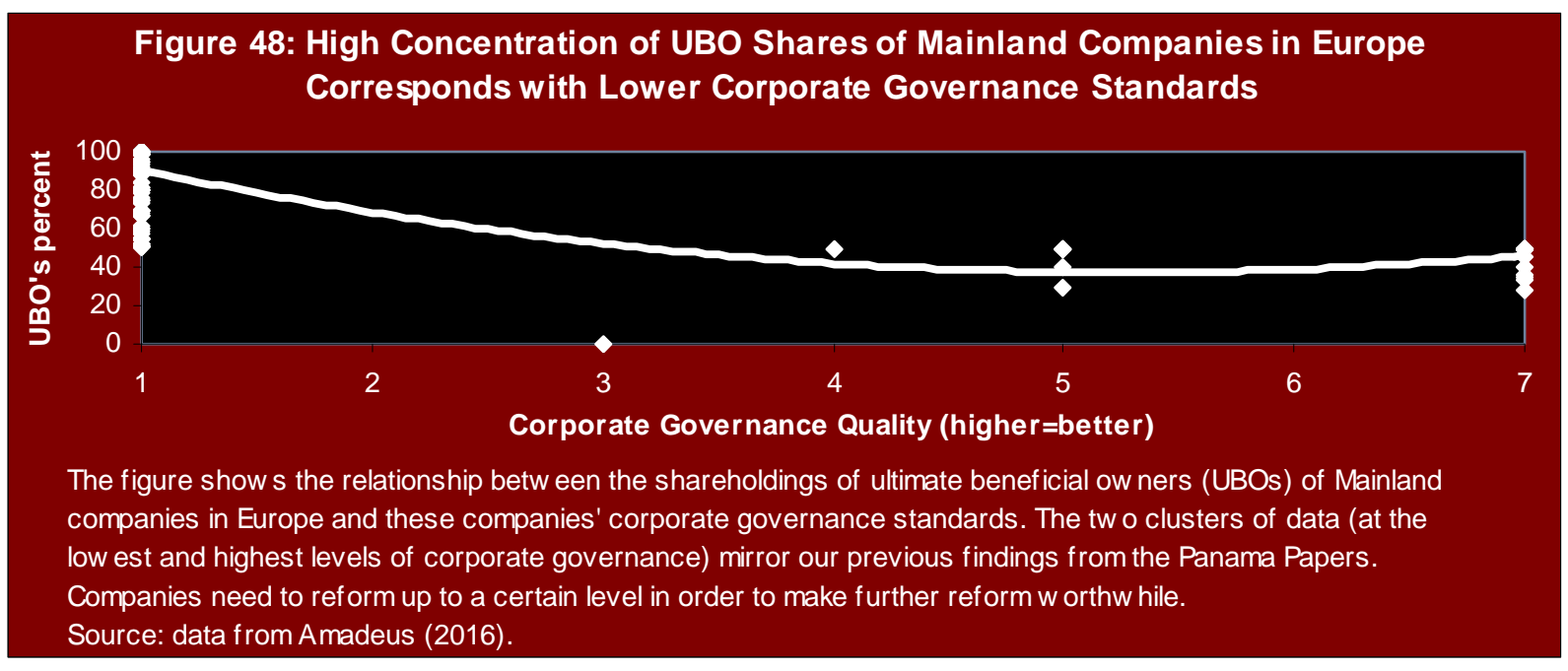

The data strongly suggest that Chinese firms won't be able to import good corporate governance practices from the jurisdictions they invest in. Figure 49 shows the geographical distribution of Mainland investment in European companies. ${ }^{274}$ Much of China's knowledge intensive investment centres on Germany and France - places with relatively good corporate governance practices. Yet, Chinese shareholders have also invested in European areas with much worse corporate governance practices - like Romania. In theory, if Chinese owners would "bond” to corporate governance practices from any European jurisdiction, their large amount of investment along the Franco-Germanic border would suggest that they should pick up governance practices from those regions. Yet, as shown by Figure 50, corporate governance in companies owned by Chinese shareholders in those places ranks extremely poorly. Chinese owned companies in Prague and Madrid have the "best" corporate governance. Yet, the governance of companies in

\footnotetext{
${ }^{272}$ Many authors have explained the concentrated ownership of Mainland firms as an attempt to reduce the problems and lack of oversight present in a widely dispersed shareholding structure. Yet, such concentration clearly does not play the pivotal role played on the Mainland - as even minority holders have relatively large influence over companies in Europe. For a discussion of these shareholders' influence, see Cheung, Yan-Leung, Ping Jiang, Piman Limpaphayom, and Tong Lu, Corporate Governance in China: a Step Forward, European Financial Management, 16(1), 2010, available online. See also Beatson, Samuel, Foreign Investment, Corporate Governance \& Performance in the Chinese Listed A Share Companies, University of Nottingham China Policy Institute Working Paper 18, 2014, available online.

${ }^{273}$ Authors like Ewing might argue that Mainland firms with significantly better corporate governance implement policies in line with the government's reforms. Thus, corporate governance and structural/economic reform go handin-hand. See Ewing, Richard, Chinese Corporate Governance and Prospects for Reform, Journal of Contemporary China 14(43), 2005, available online.

${ }^{274}$ See Zhang, Hai-Yan, Chinese Outward Foreign Direct Investment in the EU: Opportunities and Challenges for European SMEs to Link into the Global Value Chain of Chinese Multinational Enterprises, EUSME Centre Working Paper, 2014, available online.
} 
most of the other places where Chinese owners have invested remains poor. As shown by Figure 51, Controlling shareholders from/in Hong Kong-owned European companies with slightly better corporate governance than controlling shareholders from most of other Chinese cities. Yet companies owned by persons from Fuzhou, Changsha, Xian, Tianjin have better corporate governance practices than those from Hong Kong. If Hong Kong corporate governance rules/practices can influence Chinese shareholders, such an influence could improve such governance in Europe as much as on the Mainland.
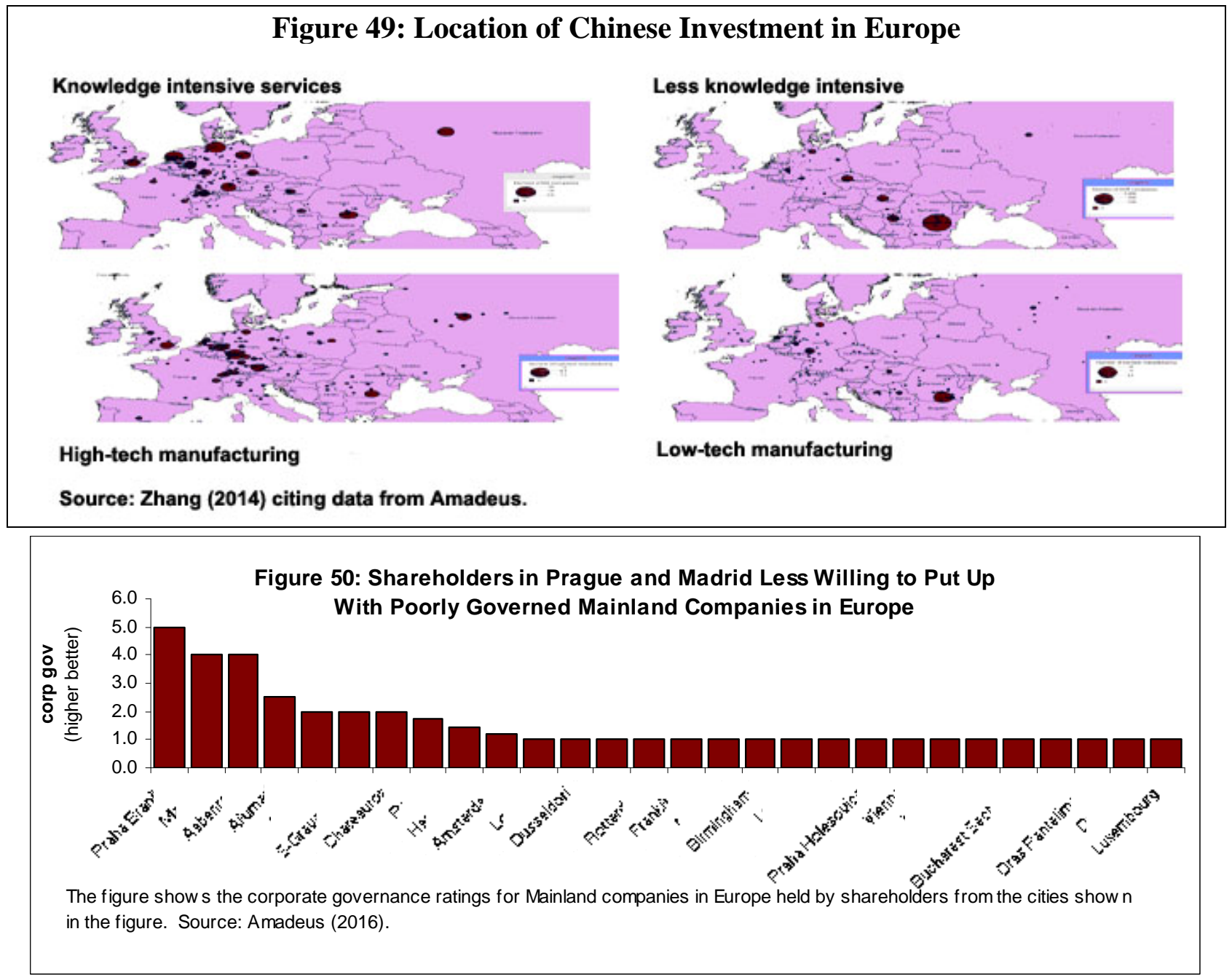


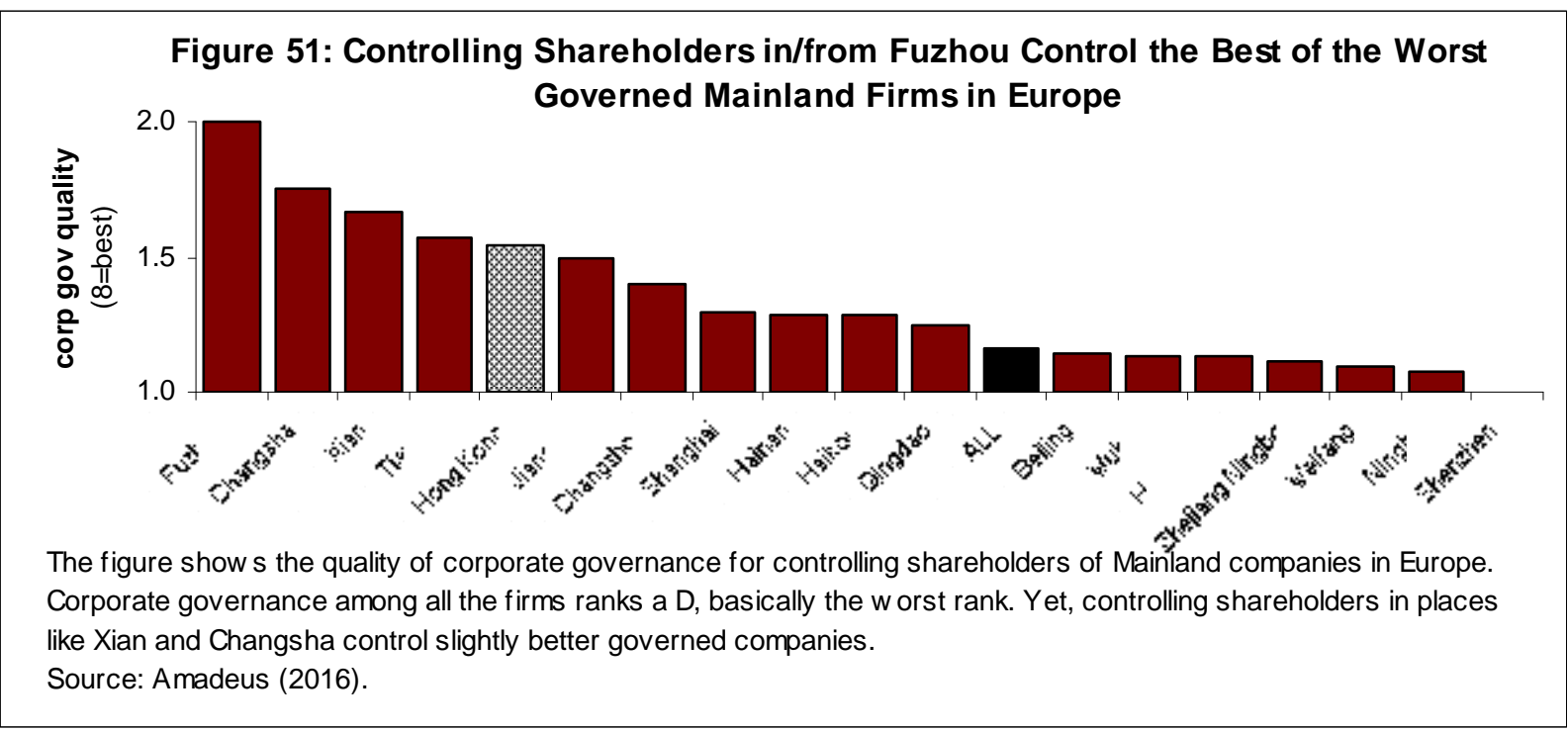

The UK's beneficial ownership database probably represents the best model for Hong Kong. Figure 52 shows the registry. ${ }^{275}$ Their register of "people with significant control" will probably cover owners of non-traded companies (as listed companies already have disclosure requirements). ${ }^{276}$ Companies must collect the information about their beneficial owners, and owners non-complying may find their assets/interests frozen. ${ }^{277}$ The law provides for the protection of privacy - like not publishing these owners' residential address and other "secure information.,278 The law also allows for reasonable explanations and appeals by the owners concerned. ${ }^{279}$ The Department for Business Innovation and Skills has already issued guidance for businesses to comply with the law as well as for the persons themselves. ${ }^{280}$ The government estimates that the policy will cost UK business around $\$ 150$ each for small companies. ${ }^{281}$

\footnotetext{
${ }^{275}$ UK Companies House, Beneficial Ownership Database, 2016, available online.

${ }^{276}$ We speak tentatively about the rules, as the scheme's rules still lie in draft form. See The Register of People with Significant Control Regulations, 2016, available online.

${ }^{277}$ Id at art. 19.

${ }^{278}$ Id at Part VI and VII respectively.

${ }^{279}$ Id at art. 19 and 25-28.

${ }^{280}$ UK Department for Business Innovation and Skills, Register of People with Significant Control

Guidance for Companies, Societates Europaeae and Limited Liability Partnerships, 2016, available online. See also UK Department for Business Innovation and Skills, Register of People with Significant Control Guidance for People with Significant Control Over Companies, Societates Europaeae and Limited Liability Partnerships, 2016, available online.

${ }^{281}$ See UK Department for Business, Innovation and Skills, Consultation stage Impact Assessments to Part A of the Transparency and Trust proposals (December 2013), 2014, available online.
} 


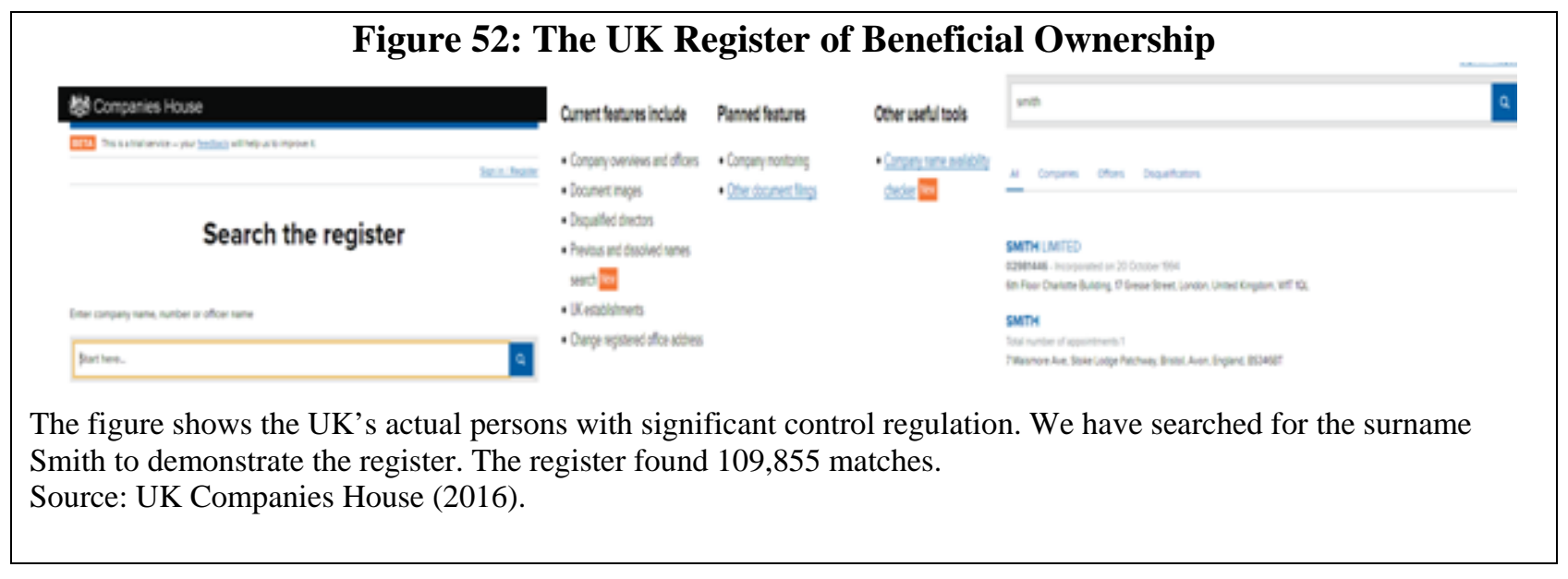

China will probably not adopt a policy to collect information on beneficial owners for a long time. At present, Mainland rules on the subject relate to a hodgepodge of seemingly ad hoc regulations, arising only to clarify previously worked regulations. State Administration of Taxation Circular 601 from 2009 and its Bulletin 30 of 2012 represent the major instruments putting in place some form of beneficiary reporting. ${ }^{282}$ In the realm of securities investment, beneficial ownership usually refers to the rights of shareholders to be identified as having property rights in shares and not the sharing of this information with third-parties like the government. For example, the China Securities Regulatory Commission (CSRC) issued a frequently-asked-questions guidance document which sought to clarify the responsibilities for reporting beneficial owners in the Qualified Foreign Institutional Investor and RMB Qualified Foreign Institutional Investor context. ${ }^{283}$ Under the Shenzhen-Hong Kong Stock Connect scheme, the CSRC Stock Connect Rules require the declaration of beneficial ownership as well as provide "northbound investors" with the rights, benefits and proprietary interests in such securities as shareholders. ${ }^{284}$ China's State Administration of Taxation's provided Notice 601 of 2009 for the purposes of determining tax treatment of beneficial owners from Hong Kong. ${ }^{285}$ The country’s commitment to its G20 pledges says all the right things - with the intent to collect and share information on beneficial owners with law enforcement and government agencies. ${ }^{286}$

Hong Kong's rules do not seem more developed than the Mainland's. In theory, by virtue of its attachment to the Financial Action Task Force (FATF), Hong Kong has signed up to guidelines related to transparency and beneficial ownership. ${ }^{287}$ Such guidance follows on from Hong Kong's commitment to adopt Recommendation 24 on Transparency and Beneficial Ownership of Legal Persons and Recommendation 25 on the transparency and beneficial ownership of legal arrangements of the FATF Recommendations on anti-money laundering and combating the

\footnotetext{
${ }^{282}$ Qiu provides an excellent overview of these two instruments. Circular 165 repeats/confirms the validity of these two prior circulars. See Qiu, Dong-Mei, The Concept of “Beneficial Ownership” in China' s Tax Treaties - The Current State of Play, Bulletin For International Taxation, 2013, available online.

${ }^{283}$ See CSRC, FAQs on Beneficial Ownership under QFII/RQFII Regime, 2016, available online.

${ }^{284}$ CSRC, FAQ on Beneficial Ownership, 2015, available online.

${ }^{285}$ CSRC, Opinion on Implementing the Dividends Provision under the Tax Arrangement between Mainland China and Hong Kong in Cases involving Beneficial Ownership, 2013.

${ }^{286}$ Government of the People's Republic of China, Measures and the Next Step China Will Take to Implement G20 High-Level Principles on Beneficial Ownership Transparency, 2015, available online.

${ }^{287}$ FATF, FATF Guidance: Transparency and Beneficial Ownership, 2014, available online.
} 
financing of terrorism (AML-CFT). ${ }^{288}$ Hong Kong's politicians have expressed a strong interest in strengthening their anti-money laundering rules, particularly in light of the FATF's next mutual evaluation in 2018. ${ }^{289}$ Yet, they have shown no interest in setting up a UK-style beneficial ownership database.

Hong Kong's Financial Secretary’s Office should militate for setting up such a database, in order expand Hong Kong as an international financial centre. Authors like Unger et al. put Hong Kong's share of illegally derived funds at $\$ 45$ billion per year. ${ }^{290}$ In other words, $\$ 45$ billion represents funds illegal derived which, in theory, can be seized and returned home. Taking these funds imposes three costs on Hong Kong's financial institutions. First, law enforcement may freeze or seize these funds, making them unpredictably unavailable for investment and forcing these financial institutions to hold enough liquid assets to wire to law enforcement bodies if ordered by the relevant court or judicial body. Because Hong Kong's authorities have not conducted the usual risk assessment quantifying these risks, we can not know the scale of the problem. ${ }^{291}$ Second, these financial institutions run reputation risks of the public identifying them as abetting crimes. Third, fines have increased significantly over the years - with many other jurisdictions requiring the collection of beneficial ownership information. ${ }^{292}$ As such, foreign judicial bodies may fine a multi-national financial services firm if a foreign investigation runs cold because Hong Kong financial services firms did not comply with beneficial ownership rules.

We thus make the three following recommendations. For recommendation 16, we urge the Financial Services and Treasury Bureau to conduct a study to assess the extent to which the declaration of beneficial ownership (and other activities) would reduce money laundering related risks. For recommendation 17, we urge the Financial Secretary's Office to work with the Hong Kong Monetary Authority, the Securities and Futures Commission, and the Financial Services and the Treasury Bureau to adopt a regulation for collecting and sharing information about beneficial owners, with the UK as a model. If the legal or political basis does not exist for such a regulation, the Office can usefully publish road map for adopting such rules - even if it means proposing legislation. For recommendation 18, we recommend putting a beta version of the eventual beneficial ownership database online.

\footnotetext{
${ }^{288}$ FATF, International Standards on Combating Money Laundering and the Financing of Terrorism and Proliferation (The FATF Recommendations), 2012, available online.

${ }^{289}$ FATF, Mutual Evaluation of Hong Kong, China, 2008, available online.

${ }^{290}$ Unger, Brigitte, Melissa Siegel, Joras Ferwerda, Wouter de Kruijf, Madalina Busuioic, Kristen Wokke, Greg Rawlings, The Amounts and the Effects of Money Laundering, Utrecht School of Economics Working Paper, 2006, available online.

${ }^{291}$ For examples of these risk assessments, see US Department of the Treasury, National Money Laundering Risk Assessment, 2015, available online. See also UK HM Treasury and Home Office, UK National Risk Assessment of Money Laundering and Terrorist Financing, 2015, available online. See also Japanese National Risk Assessment of Money Laundering and Terrorist Financing Working Group, National Risk Assessment of Money Laundering and Terrorist Financing, 2014, available online.

${ }^{292}$ We repeat our previous complaint, that lack of information and previous studies prevents us from quantifying such an effect for Hong Kong. Yet, for the US, see Brown-Hruska, Sharon, Developments in Bank Secrecy Act and Anti-Money Laundering Enforcement and Litigation, NERA Brief, 2016, available online.
} 
Recommendation 16: Financial Services and Treasury Bureau conducts and publishes a money laundering risk assessment in line with those conducted by the US, UK and Japan in order to identify and quantify the risks from beneficial ownership fraud.

Recommendation 17: Financial Secretary's Office to work with the Hong Kong Monetary Authority, the Securities and Futures Commission, and the Financial Services and the Treasury Bureau to adopt rules for collecting and sharing beneficial ownership information, with the UK as a possible model (or at least a published road map for adopting such legislation).

Recommendation 18: Put a beta version of such a beneficial ownership register online.

\section{Tackling Intermediaries in the Offshore Game}

\section{Increased supervision and punishment of accountants and lawyers}

The lawyers, bankers and accountants responsible for listing Chinese corporation on foreign exchanges clearly have not investigated their clients sufficiently. Figure 53 shows the number of reverse mergers organised for Chinese companies in order to list in the US. ${ }^{293}$ As shown, the reverse mergers orchestrated by these Chinese companies' legal and financial advisors delisted after about 6 years due to fraud or other malfeasance. Figure 54 shows the Bloomberg Chinese reverse merger index and the number of class action lawsuits against these Mainland corporations. As shown, the reverse merger index fell as fraud cases piled up - showing how lax corporate governance can harm company valuations. Many observers blame reverse mergers themselves for the reduction of the quality of listed companies. Yet, as Chen and colleagues note, a "China effect” explains these listings' problems much better than any "reverse merger effect.,"294 Mainland companies' legal and financial advisors clearly failed to detect and rectify significant weaknesses in these companies' accounting and corporate governance standards - leading to valuations which only came to half those of their IPO counterparts. ${ }^{295}$ The standard story thus

\footnotetext{
${ }^{293}$ See Charles Lee, Kevin Li, and Ran Zhang, Shell Games: The Long Term Performance of Chinese Reverse Merger Firms, 2014, available online.

${ }^{294}$ See Chen, Kun-Chih, Cheng Qiang, Ying-Chou Lin, Yu-Chen Lin and Xiao Xing, Financial Reporting Quality of Chinese Reverse Merger Firms: The Reverse Merger Effect or the China Effect?", Singapore Management University's School of Accountancy Working Paper 12-2013, 2013, available online.

${ }^{295}$ Initial public offerings (IPOs) result in the listing of companies following higher standards due the significant screening done before listing. In contrast, screening of companies listing via reverse mergers remains lax in the US, Hong Kong and other jurisdictions. Yet, not everyone agrees about these harms. Chai et al. dispute that reverse merger firms perform worse than IPOs or Chinese companies based in the US. Chai and Lau see nothing sinister about the delisting we have shown - as companies with poor corporate governance got kicked out, and those staying adopted even higher corporate governance standards. See also Chai, Mary and Virginia Lau, Bonding versus Avoiding Theory: Evidence from Accrual and Real Earnings Management of Chinese Reverse Merger Companies, AFAANZ 2016 Conference, available online. For the market value statistics we cite, see PCAOB, Activity Summary and Audit Implications for Reverse Mergers Involving Companies from the China Region: 2 January 1, 2007 through March 31, 2010, PCAOB Research Note 2011-P1, available online. See also Chai, Mary Virginia Lau, Kitty Xie,
} 
goes that as poor corporate governance in China led to significantly more fraud in Chinese listed companies, these companies used backdoor listings enabled by their legal and financial advisors to avoid scrutiny of their poor corporate governance practices, and the eventual destruction of shareholder value concomitant with investor skittishness and delisting. ${ }^{296}$
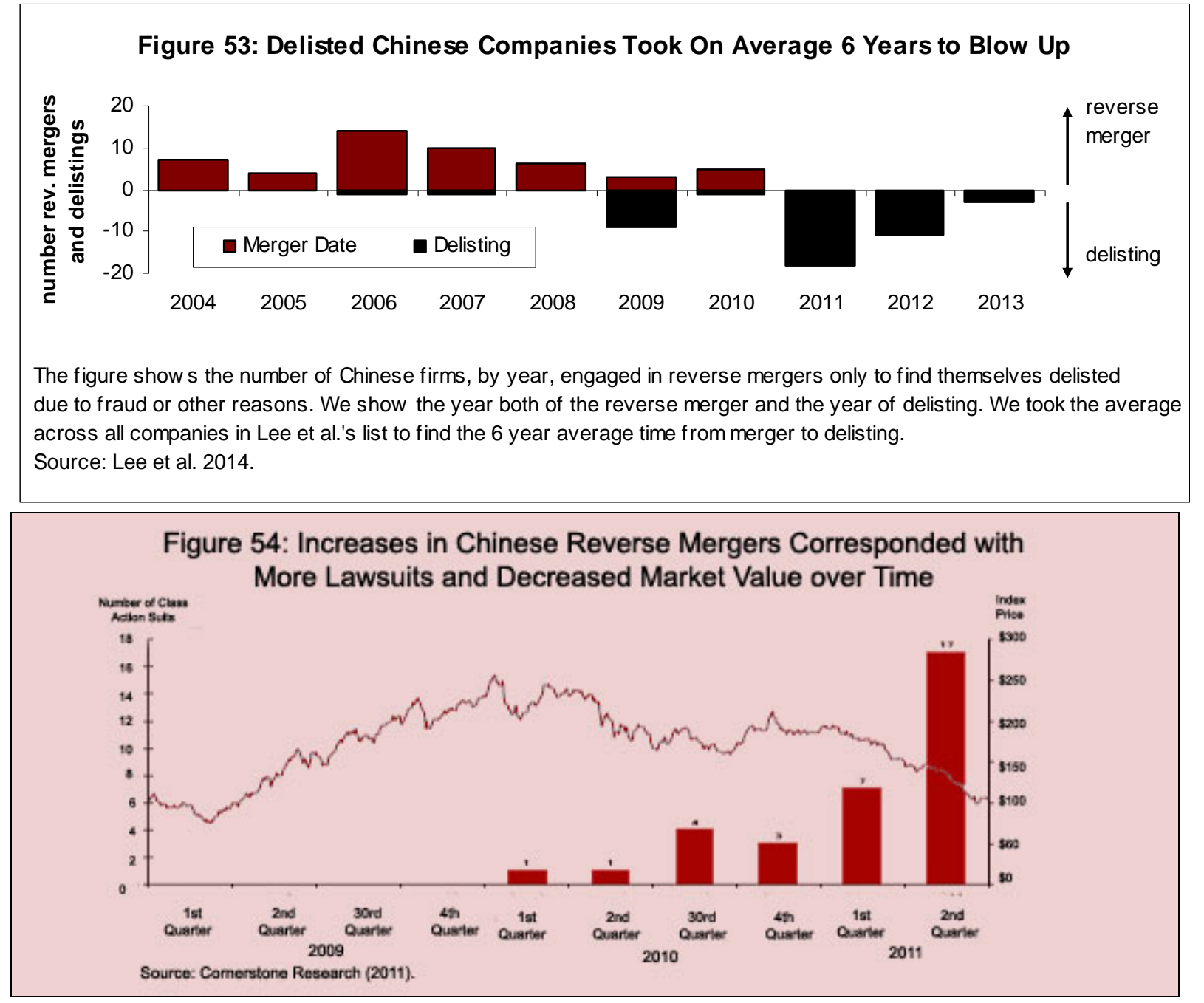

Hong Kong's legal and financial advisors obviously fare no better in advising their clients. Figure 55 shows the number of cases appearing in Hong Kong's courts due to poor corporate governance, fraud or disputes over mergers and so forth. Shareholder fraud represents the largest reason for litigation in Hong Kong's courts among the four factors we searched for - namely shareholder fraud, disputes over mergers, backdoor listings, and/or corporate governance-related

The End Justifies the Means? Signalling Effect of How and Where to List, Paper\#: K227, Seventh Asia Pacific Interdisciplinary Research in Accounting Conference, Kobe 26-28 July, 2013, available online.

${ }^{296}$ Jindra et al represent one of the many, many papers to make this link. See Jan Jindra, Torben Voetmann, and Ralph A. Walkling, Reverse Mergers: The Chinese Experience, Fischer College of Business Working Paper 201203-018, 2012, available online. 
disputes. $^{297}$ Such disputes have increased, in absolute terms, over the course of the last decade. Many of these cases would not have proceeded into litigation if these companies' legal and/or financial advisors had exercised more foresight.

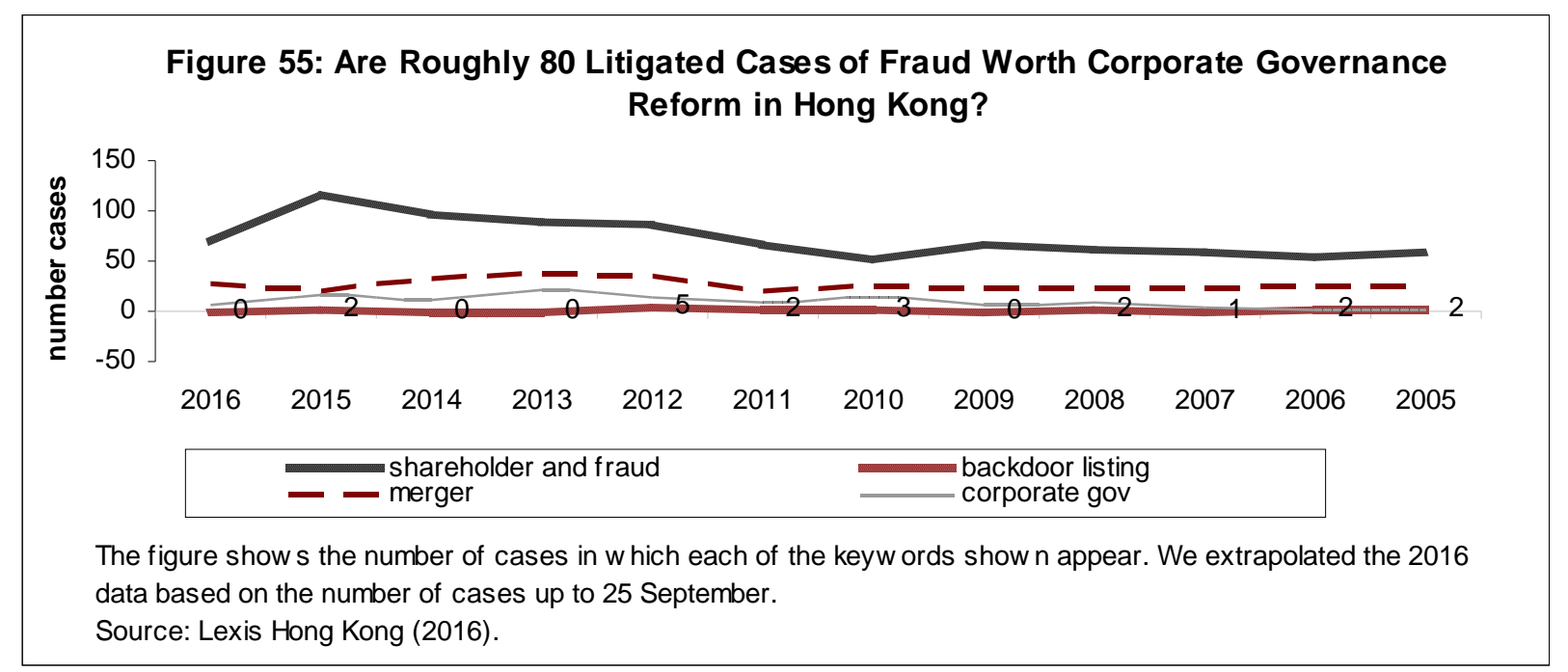

Both the Panama Papers, and numerous other studies, show how shell companies can incentivise corporate managers and owners to engage in poor corporate governance practices. The recent World Bank study on shell companies provides numerous examples of poor corporate governance allowing companies using shell companies to siphon away money. ${ }^{298}$ A Basel Committee on Banking Supervision communiqué signed by several officials from tax havens such as Jersey, Bermuda, Cayman, and Guernsey -- urged the closing of shell banks and offshore booking centres in 2003. ${ }^{299}$ Yet, over the subsequent decade, nothing happened. As shown in Figure 56, the Panama Papers data indicate that at least 12 offshore banks and 3 intermediaries in Hong Kong had dealings with Mossack Fonseca. These numbers may not appear large. But taking into account finance and securities companies as well, over 500 companies had a touch with Hong Kong. Some famous names include Deutsche Bank, Dah Sing Bank, HSBC, and Societe Generale. Hong Kong’s legal and financial advisors clearly participated in dubious and opaque practices not in the long-term interests of their clients.

\footnotetext{
${ }^{297}$ For the last factor, we simply searched on the key word "corporate governance” - thus we do not try to dig too deeply into exactly what the experts categorizing under that rubrique.

298 See Willebois, Emily, Emily Halter, Robert Harrison, Ji Won Park, and J.C. Sharman, The Puppet Masters: How the Corrupt Use Legal Structures to Hide Stolen Assets and What to Do About It, 2011, available online. For example, Anglo-Leasing (Kenya) won a lucrative government tender to supply passport services at a cost five times higher than the lowest bidder. This UK mailbox-registered company subcontracted to the French firm who actually put in the lowest bid to do the work. In another case, investigators found that DaimlerChrysler Automotive Russia SAO sent improper payments to 25 bank accounts scattered around the world in order to engage in, and hide, bribe payments. Without these avenues to launder money, these firms' corporate governance might have been better.

${ }^{299}$ Basel Committee on Banking Supervision, Shell Banks and Booking Offices, 2003, available online.
} 


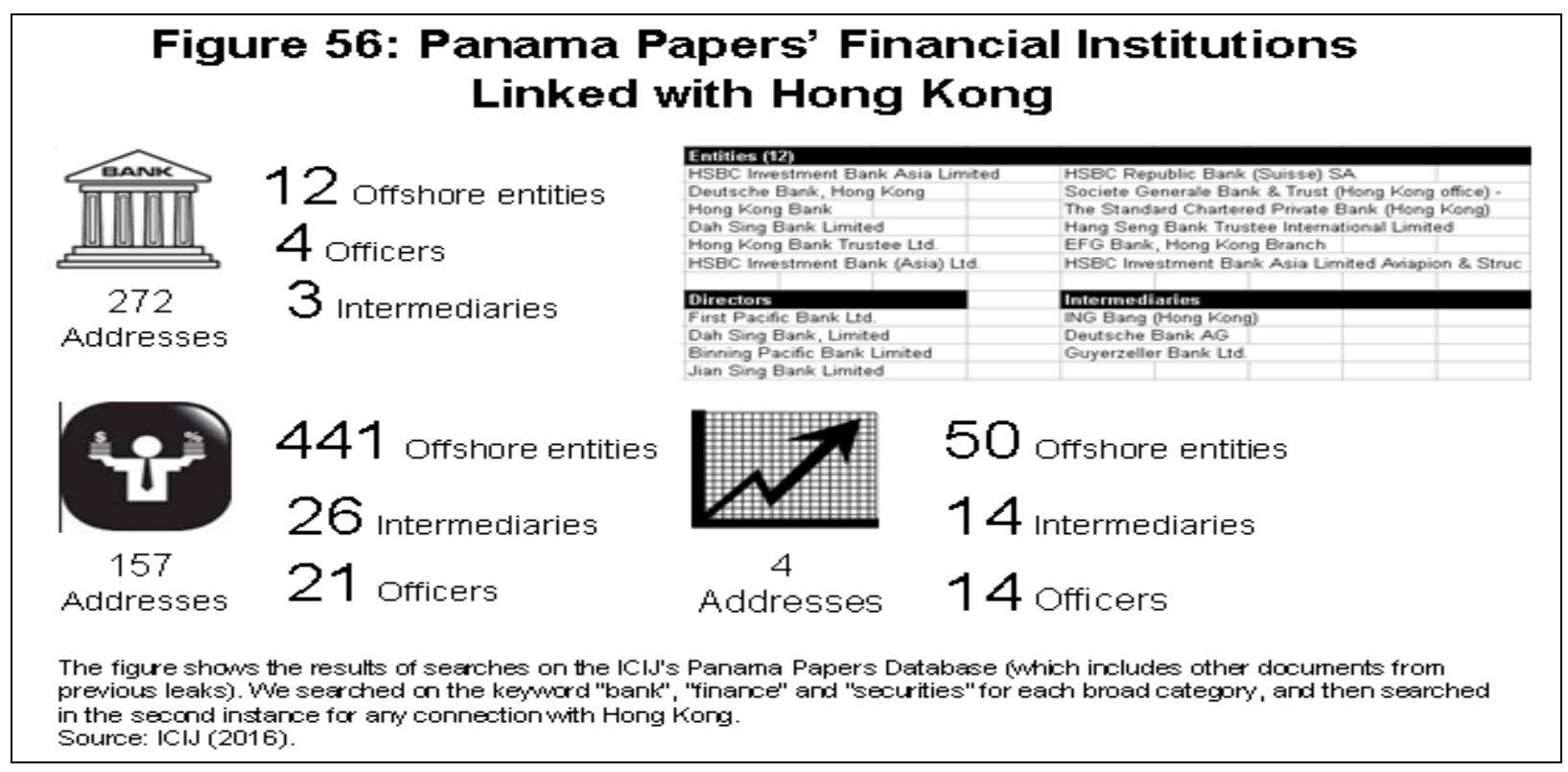

The Panama Papers illustrated the role that accountants, lawyers, corporate secretarial service providers and other professional firms played in distributing shell companies. Hong Kong's authorities will be unlikely to fight shell company incorporations without a legal approach able to sanction professional service providers at home and in foreign jurisdictions. Figure 57 shows the percent of professional services firms accepting an approach to provide a shell company to an individual posing as a client engaged in illegal/unethical conduct. ${ }^{300}$ Hong Kong's professionals refuse suspicious applications for shell companies far more often than other jurisdictions. Yet, as figure 58 shows, Hong Kong's law firms lodge only a small fraction of suspicious transaction reports as financial services firms. ${ }^{301}$ Even if Hong Kong's lawyers do not help Mainland businesspersons set up shell companies in order to launder money, they probably know about such attempts. Hong Kong's significant investment and trade relationships with many of these countries - including the US and UK - mean that fraudulent companies can work with Hong Kong "through the back door."

\footnotetext{
${ }^{300}$ See Michael Findley, Daniel Nielson, and Jason Sharman, Global Shell Games: Testing Money Launderers’ and Terrorist Financiers' Access to Shell Companies, 2012, available online.

${ }^{301}$ See Mulrenan, Stephen, Asia: Panama Papers - No News Is Good News, International Bar Association's Global Insight June/July, 2016, available online.
} 

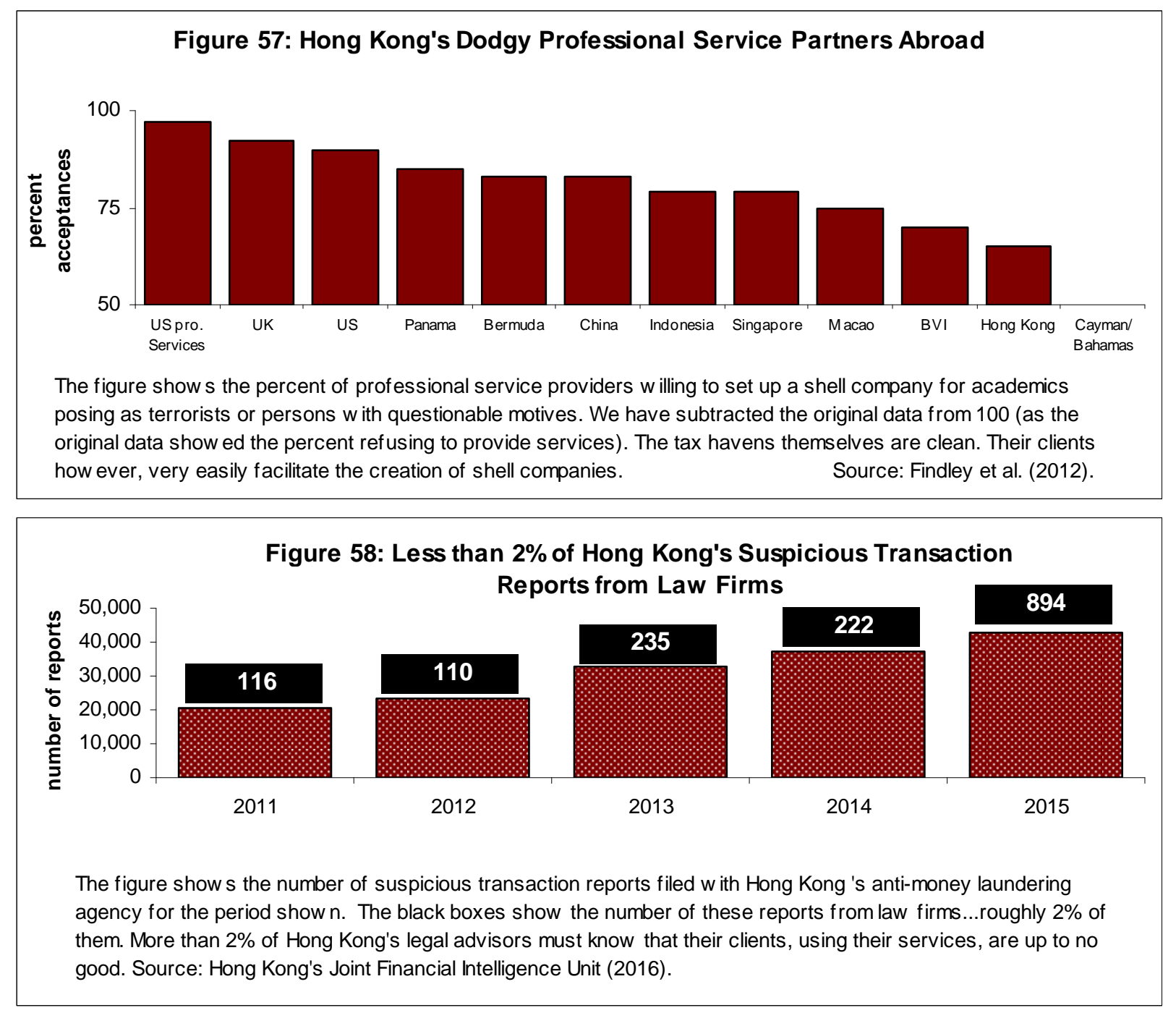

Lawyers, accountants and other intermediaries should use the same client handling procedures and risk management procedures as those used in banks and the large corporate secretarial firms. At the most extreme, these include procedures aimed at money laundering and the finance of terrorism - a topic which Hong Kong has wholeheartedly embraced. ${ }^{302}$ In Hong Kong, the recent conviction of a lawyer for money laundering signals a willingness to engage law firms in the fight against money laundering and complicity with corporate crime. ${ }^{303}$ Hong Kong's Law Society issued its Practice Direction P in 2008 as way to tackle money laundering by making lawyers better identify and verify clients, conduct more risk-focused customer due diligence, and

\footnotetext{
${ }^{302}$ For some of the rules which the UK’s Solicitors Regulatory Agency has promulgated to reduce the risk that lawyers abet money laundering, see UK Solicitors Regulatory Agency, Cleaning Up: Law Firms and the Risk of Money Laundering, 2014, available online. For a more cross-jurisdictional approach, see Stephen Revell, Stephen and Kevin Shepherd, A Lawyer's Guide to Detecting and Preventing Money Laundering: A Collaborative Publication of the International Bar Association, the American Bar Association and the Council of Bars and Law Societies of Europe, 2014, available online.

${ }^{303}$ See So, Peter, Solicitor Convicted of Money Laundering, Deacons Litigation \& Dispute Resolution Newsletter 4 November, 2014, available online.
} 
keep better records. ${ }^{304}$ The HKICPA has issued guidance for accounting firms on handling money laundering. ${ }^{305}$ The Hong Kong Institute of Chartered Secretaries has recently promulgated a Guideline and associated accreditation scheme for members interested in certifying their compliance with key money laundering provisions. ${ }^{306}$ Yet, provisions like those applied to the banking sector look unlikely in the medium-term due to the extra costs they would impose on Hong Kong's professional services sector. ${ }^{307}$ Even if these organisations manage to implement these regulations, available econometric evidence shows that few clients/members would comply. ${ }^{308}$ Social and political pressures explain why so many jurisdictions - like Hong Kong have adopted money laundering regulations but have not enforced them very successfully. ${ }^{309}$ Board members can not simply divorce money laundering rules from the broader transformation in improving overall corporate governance. ${ }^{310}$ Lawmakers need to adopt better rules than the current anti-money laundering regulations in order to incentivise companies to improve their corporate governance.

Nothing requires Hong Kong's professional services firms to move toward a risk-based approach toward clients which could detect high risk clients with poor corporate governance practices (and at little extra cost to themselves). Nothing in the Solicitor's Practice Ordinance requires solicitors to look at clients' risks (or any kind of risks affecting the practice). ${ }^{311}$ Hong Kong should not follow the US's “gatekeeper” approach to introducing risk-based assessment and risk management into the legal and other service professions. ${ }^{312}$ The UK's Solicitors Regulatory Authority and the UK Law Society have best "mainstreamed" such a risk-based approach into its

\footnotetext{
${ }^{304}$ For the Practice Direction, and related Circular 07-726 and Circular 02-384, see Huang, Lester and Lintern-Smith, Michael, The New Practice Direction P and Its Implications, Law Society of Hong Kong Training Materials, 2008, available online.

${ }^{305}$ See Anti-Money Laundering Bulletin: Requirements on Anti-Money Laundering, Counter-Terrorist Financing and Related Matters, HKICPA Anti-Money Laundering Bulletin 1, 2015, available online.

${ }^{306}$ See HKICS, The Hong Kong Institute of Chartered Secretaries Anti-Money Laundering and Counter-Terrorist Financing Guideline, 2016, available online. See also HKICS, The Hong Kong Institute of Chartered Secretaries Anti-Money Laundering and Counter-Terrorist Financing Charter, 2016, available online.

${ }^{307}$ As usual, the government has not performed any rigorous economic study looking at the costs and benefits of its regulations. For a journalistic account, see Shih, Toh, Money Laundering Law Could Extend to Non-Financial Firms, South China Morning Post 28 May, 2014, available online.

${ }^{308}$ For the data, see Verdugo, Concepcion, Compliance with the AML/CFT International Standard: Lessons from a Cross-Country Analysis, IMF Working Paper WP/11/177, 2011, available online.

309 See Sharman, JC., The Global Anti-Money Laundering Regime and Developing Countries: Damned if they Do, Damned if they Don't? U4 Working Paper, 2006, available online.

${ }^{310}$ Bruemmer and Alper do an excellent job at explaining in details the broader change needed in board-level education and risk assessment. For her part, Loughrey describes adriotly the problems with simply delegating “compliance” to in-house lawyers. See Bruemmer, Russell and Elijah Alper, AML: A Corporate Governance Issue The Banking Law Journal Nov/Dec, 2013, available online. See also Loughrey, Joan, Corporate Lawyers and Corporate Governance, 2011.

${ }^{311}$ Specifically Rule 2 on general conduct does not mention the need of solicitors to identify or manage risks. See Solicitor Practice Rules, Chap 159H, 1997 (and updated several times subsequently), available online.

${ }^{312}$ Shephard describes in great length all the various documents and initiatives created as a way to encourage lawyers to adopt the risk-based approach to money laundering and corporate malfeasance which is quickly becoming the norm in the services. See Shepherd, Kevin, The Gatekeeper Initiative and the Risk-Based Approach to Client Due Diligence: The Imperative for Voluntary Good Practices Guidance for U.S. Lawyers, 2010, available online.
} 
legal services industry. ${ }^{313}$ Moreover, the Authority issued new rules as part of its Handbook to move toward the wider adoption of principles-based, outcomes-based regulation. ${ }^{314}$ Similarly, nothing in Hong Kong's Professional Accountants Ordinance encourages the Hong Kong Society of Accountants or the Hong Kong Institute of Certified Public Accountants to adopt a risk-based approach as a means to accomplish one its primary tasks as to "discourage dishonourable conduct and practices by certified public accountants."315 Even in the Companies Ordinance, nothing requires boards to set up risk committees or manage risks like staff complicity in money laundering or other financial crime. ${ }^{316}$ While the Hong Kong Institute of Chartered Secretaries imposes based-based guidelines on its members, the Institute makes no mention of internal rules about its own risk management practices (if any). ${ }^{317}$ Hong Kong's legal, accounting and corporate services firms - like their clients - also need to modernise their corporate governance practices (in one way by adopting a risk-based approach in managing their customers and their own corporate governance issues).

Thus, in our to continue Hong Kong's adoption of principles-based, outcome-driven law, our nineteenth recommendation notes that law firms, accounting firms and corporate services firms in Hong Kong law may usefully adopt requirements on professional service firms and corporate boards to set up risk committees and a risk register - as well as adopt a risk-based approach to compliance. ${ }^{318}$ Unlike at present, such an approach would cover more than just money laundering. ${ }^{319}$ Such an approach would reduce the need for extensive and detailed regulations as well as costly compliance systems - thus saving listed firms and others money. ${ }^{320}$ Such an approach would also probably encourage compliance with corporate governance and other regulations. ${ }^{321}$

\footnotetext{
${ }^{313}$ The Authority has produced a number of clearly written, easily found reference materials describing the use of such a risk-based approach. See UK Solicitors Regulatory Authority, SRA Risk Framework, 2008, available online. See also UK Law Society, The Risk-Based Approach - What Is It?, 2008, available online.

${ }^{314}$ Aon Risk Solutions, Professional Services Group Risk Registers - A Practical Approach for Solicitors, 2013, available online.

${ }^{315}$ See Professional Accountants Ordinance Chapter 50, 2004, at sec. 7, available online.

${ }^{316}$ The only related requirement concerns directors' disclosure of risks in their report. See Companies Ordinance, Chap. 622, at schedule 5, available online.

${ }^{317}$ See HKICS, About Us, 2016, available online.

${ }^{318}$ Recent analyses of the global financial crisis of 2007-8 have particularly stressed the need to introduce broader risk management principles into company law and the sectoral rules governing the financial sector. See Sun, William Jim Stewart, David Pollard (Eds.), Corporate Governance and the Global Financial Crisis: International Perspectives, 2011.

${ }^{319}$ In contrast to the UK or US, most of our searches on risk-based approaches in Hong Kong yielded results only for banks and financial service firms and/or only for money laundering risks. See SFC, AML/CFT Self-Assessment Checklist, available online.

${ }^{320}$ The cost savings represent one of the key reasons for most professions (especially banking) to advocate such riskbased approaches. For a fuller description, see Ford, Christie, New Governance, Compliance, and Principles-Based Securities Regulation, American Business Law Journal 45(1), 2008, available online.

${ }^{321}$ We have already shown evidence that firms fail to comply with corporate governance and money laundering regulations because of their cost and complexity. Such a results-based, risk-oriented focus might thus lower costs and encourage compliance. See Harvey, Jackie, Compliance and reporting issues arising for financial institutions from money laundering regulations: a preliminary cost benefit study, Journal of Money Laundering Control 7(4), 2006, available online.
} 
Recommendation 19: Eventually adjust the Solicitors Practice Ordinance, Professional Accountants Ordinance and the Companies Ordinance to reflect the obligation/right for professional services firms and company boards to adopt a risk-management perspective as way of dealing with compliance and risk - as well as scrutinize high-risk clients by extra monitoring.

Policymakers can reform the intermediaries that enabled poor corporate governance across countries and industries. As the ICIJ - the group who brought the Panama Papers to light - noted "the offshore system relies on a sprawling global industry of bankers, lawyers, accountants and these go-betweens who work together to protect their clients' secrets. These secrecy experts use anonymous companies, trusts and other paper entities to create complex structures that can be used to disguise the origins of dirty money." ${ }^{222}$ Most analysts wrongly focus on legality of the structures and rules used by Mossack Fonseca and others to create and use offshore corporations. $^{323}$ They also wrongly focus on the narrow, specific results of establishing offshore companies - in avoiding taxes. ${ }^{324}$ The inability of lawmakers to change the domestic legislation that allows intermediaries to set up offshore entities results from the wrong conclusions used by critics of these rules. As we already showed, the real harm resulting from the rules which enabled Mossack Fonseca stemmed from the opacity which enabled the no corporate governance of the offshore entities themselves and the poor corporate governance of companies associated with them. ${ }^{325}$

Regulatory amendments should thus focus on the corporate governance consequences of intermediaries' setting up offshore structures - and not on ethics. ${ }^{326}$ What role will intermediaries play in setting up and operating offshore companies when tax authorities around the world adopt "place of effective management" (or a similar test) when deciding on regulation and taxation? ${ }^{327}$ Do rules and intermediaries' practices which encourage opacity contribute to good corporate governance of these intermediaries' companies and their clients? The academic literature seems to show that, in the longer run, lawmakers tend to ban these practices exactly because of scandals like the Panama Papers imbroglio. ${ }^{328}$ Stakeholders in the corporate ecosystem prefer transparency

\footnotetext{
${ }^{322}$ ICIJ, Giant Leak of Offshore Financial Records Exposes Global Array of Crime and Corruption, 2016, available online.

${ }^{323}$ See Harrington, Brooke, Panama Papers: The Real Scandal Is What's Legal, Atlantic Monthly 6 April, 2016, available online.

324 The Guardian represents one of the countless media outlets portraying the Panama Papers Scandal in a sombre light because of the negative effects these offshore entities had on tax collection. See Garside, Juliette, Fund run by David Cameron's father avoided paying tax in Britain, Guardian 4 April, 2016, available online.

${ }^{325}$ Some rules do focus on governance in particular areas - like fund management. Yet, the rules most concern offshore structures as investments rather than as companies in their own right. See Chambers, Mark and Darren Bacon, Offshore Funds: Committed to Corporate Governance, PLC Magazine April, 2012, available online.

${ }^{326}$ Such a focus reflects a broader push in the social sciences to judge law by its systemic consequences rather than by normative criteria. For an excellent review, see Scheffer, David, The Ethical Imperative of Curbing Corporate Tax Avoidance, Ethics \& International Affairs 27(4), 2013, available online.

${ }^{327}$ See Gutuza, Tracy, Has Recent United Kingdom Case Law Affected the Interplay between Place of Effective Management and Controlled Foreign Companies, South Africa Mercantile Law Journal 24, 2012, available online.

${ }^{328}$ For an unusually lucid (even if somewhat dated) account, see Romano, Roberta, The Sarbanes-Oxley Act and the Making of Quack Corporate Governance, Yale Law \& Econ Research Paper 297, 2004, available online.
} 
because of the better decisions coming from perfect-ish informational. ${ }^{329}$ Authors like Dallas have noted that lack of transparency distorted corporate governance to such as a degree as to contribute to the financial crisis of 2007-2008. ${ }^{330}$ Against this background, corporate governance rules have increasingly moved away from requiring transparency for specific activities and toward a general "presumption of transparency" (that the company shall report and disclosure as the default option unless such disclosures cause harm). ${ }^{331}$

Our twentieth recommendation thus ties together the discussion about transparency and a promoting risk-based approach in companies as well as the intermediaries who work with them to set up offshore structures. In line with the evolving of transparency, Hong Kong's professional bodies and associations (like the Law Society, the Hong Kong Institute of Certified Public Accountants and the Hong Kong Institute of Chartered Secretaries) should encourage transparency - rather than confidentiality - as a corporate governance "default position.” Rules for the professions should encourage these professions to provide advice which enhanced - rather than hinders - transparency. The Mossack Fonseca case threw the transparency of professional service firms themselves into the spotlight. We do not recommend the prohibition or deincentivisation of professional services firms from enabling tax or regulatory avoidance. Instead, we note better governed firms - including professional services firms - engage in less avoidance, using loopholes and skirting the law. ${ }^{332}$ Thus, as professional associations and bodies encourage transparency and good corporate governance, such work will discourage the kind of activities which represent reputation risks for intermediaries and their clients.

Recommendation 20: The Law Society, the Hong Kong Institute of Certified Public Accountants and the Hong Kong Institute of Chartered Secretaries to adopt professional rules to include a presumption of transparency which discourages the supply and demand for legal/regulatory avoidance.

\footnotetext{
${ }^{329}$ In theory, no information can be complete and perfect (as an economist would understand it). For an analysis of the incentives which drive information and corporate governance, see Bushman, Robert and Abbie Smith, Transparency, Financial Accounting Information, and Corporate Governance, Economic Policy Review 9(1), 2003, available online.

${ }^{330}$ While most scholars agree about the lack of transparency in securitisation, most still do not agree on the extent to which opacity contributed to the crisis. Dallas might argue that lack of information leads to short-termism, as constrained information makes guessing about consequences more difficult. For a comprehensive analysis, see Dallas, Lynne, Short-Termism, the Financial Crisis, and Corporate Governance, Journal of Corporation Law 37, 2011, available online.

${ }^{331}$ Such a presumption fits in with the corporate governance-as-relationship view that the 2014 UK Code of Corporate Governance adopts. See UK Financial Reporting Council, The UK Corporate Governance Code (September 2014), 2014, available online.

${ }^{332}$ For more proof, see Kerr, Jon, Richard Price and Francisco Roman, The Effect of Corporate Governance on Tax Avoidance: Evidence from Governance Reform, 2016, available online.
} 


\section{Shutting Out the Major Useless Incorporation Centres}

Hong Kong belongs to a network of offshore financial centres. Figure 59 shows the jurisdiction and number of Hong Kong's listed companies. The British Virgin Islands plays a key role in Hong Kong's foreign investment and incorporation business. Hong Kong could plausibly attract productive companies from the US, UK, Singapore, and the Mainland. But what productive enterprise needs investment in the Cayman Islands, the BVI or Liberia? The Mossack Fonseca hack revealed Hong Kong's importance in the wider networks of offshore companies cycling money to each other. ${ }^{333}$ Yet, given the wide-spread adoption of anti-money laundering and related regulations across the financial centres, combined with low taxes in many jurisdictions nowadays, one must ask what benefits do Hong Kong companies get from incorporating elsewhere? Given Hong Kong's regulatory similarity with the BVI and other offshore centres, why would companies need these other offshore centres' services at all? ${ }^{334}$

\section{Figure 59: Why Do We Accept Shells from BVI and Other Incorporation Mills?}

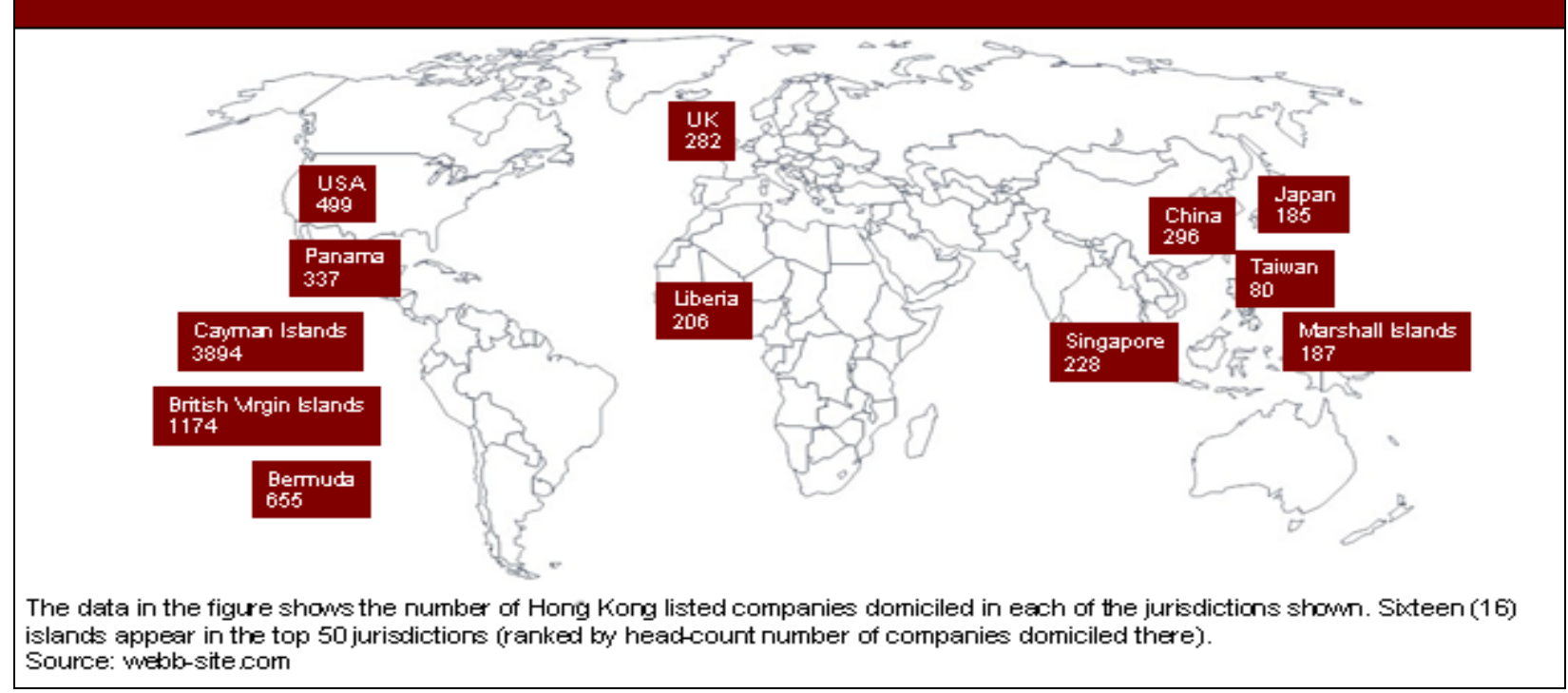

The Mainland has already started regulating away corporate structures incorporated in offshore financial centres whose main function consists of skirting taxes and other rules. ${ }^{335}$ Like many jurisdictions, the Mainland has implemented this by adopting General Anti-Avoidance Rules in areas like its tax law. ${ }^{336}$ Two key principles the government - and thus business - have slowly adopted comprises "substance over form" and "reasonable commercial purpose" tests. Circular

\footnotetext{
${ }^{333}$ See Kinetz, Erika and Kelvin Chan, Hong Kong Emerges as Hub for Creating Offshore Companies, AP The Big Story April, 2016, available online.

${ }^{334}$ For more on this convergence, see Sharman, J., Power and Discourse in Policy Diffusion: Anti-Money Laundering in Developing States, International Studies Quarterly 52(3), 2008, available online.

${ }^{335}$ Most of the material in this section comes from Ross and Zhou. See Ross, Lester and Kenneth Zhou, Application of China's General Anti-Avoidance Rules (GAAR): Lessons Learned from Recent Enforcement Cases, 2010, available online. See also McDermott Will \& Emery, China’s New General Anti-Avoidance Rules: An Overview, 2015, available online.

${ }^{336}$ PRC Enterprise Income Tax Law, 2008, at art. 47
} 
[2009] No. 698 in particular requires the disclosure (to the government at least) of any "indirect" offshore transaction and requires tax payment if the rules in the jurisdiction allow the payment of $12.5 \%$ in tax and/or no tax on foreign income. ${ }^{337}$ If the foreign entity represents a "conduit" for the original Chinese company, the tax authorities can charge 10\% withholding tax. Order 32 from 2014 provides more concrete guidance. ${ }^{338}$ Yang has estimated that the Chinese government collects RMB60 billion (roughly $\$ 9$ billion) more in revenue from the requirement. Such rules promote good corporate governance by discouraging companies from building complex corporate and tax relationships in an effort to subvert the tax rules. Chinese and global law has increasingly adopted legitimate economic purpose tests as a way to benefit government (through increased revenue) and corporations themselves (by removing perverse incentives to use poor corporate governance practices as a way of saving money).

Anti-avoidance tax rules in Hong Kong also lay the foundation for a wider-spread legitimate economic purpose test. The Hong Kong tax code in particular requires tax assessors to consider the "the form and substance of the transaction" (much like the Mainland rules) and the intent (whether for reasonable commercial purposes or simply to obtain a tax benefit). ${ }^{339}$ While Hong Kong's tax code has not adopted the reasonable commercial purpose language, its "dominant purpose" test basically serves the same purpose. ${ }^{340}$ As shown in Figure 60, Yang provides a fascinating account of the way the "reasonable commercial purposes" test evolved in Hong Kong and on the Mainland. ${ }^{341}$ On the Mainland, the tax authorities over time expanded their ability to apply the test. In contrast, the principle itself consisted of seven sub-tests and Hong Kong's courts weakened the provision by ruling against the tax authorities on numerous occasions. Despite Hong Kong's hostility to applying a "reasonable commercial purposes test," the principle is not foreign to Hong Kong law and practice.

\footnotetext{
${ }^{337}$ The rule unrealistically requires the foreign seller to make the declaration to the Chinese tax authorities - thus non-compliance should be the norm. Yet, the principles of anti-avoidance are slowly gaining in importance in the daily life of corporate China. Circular 81, Circular 124 and Circular 601 (all of 2009) outline the general principles and criteria for applying these principles.

${ }^{338}$ See Administrative Measures for General Anti-avoidance Rules (SAT Order [2014] No. 32, available online. For an overview and analysis, see E\&Y, China Released Administrative Measures for General Anti-Avoidance Rules (GAAR), China Tax \& Investment News CTIN2014002, 2014, available online.

${ }^{339}$ See Inland Revenue Ordinance, CAP. 112, at art. 61a. The rule does not require or define the principles of a legitimate commercial purpose test like the one we describe in this article. We thus interpret the converse of structuring a transaction or party to obtain a tax benefit as a legitimate commercial purpose.

${ }^{340}$ IRD, DEPARTMENTAL INTERPRETATION AND PRACTICE NOTES NO. 15(REVISED), 2006, at para 33, available online.

${ }^{341}$ Yang, Ya-Ting, China (People's Rep.)/Hong Kong: A Comparative Study of the General Anti-Avoidance Rules of Mainland China and Hong Kong - Legislation, Interpretation and Application, Bulletin for International Taxation 70(7), 2016, available online.
} 


\section{Figure 60: The Difierent Trajectories of Economic Purpose Tests in Hong Kong and on the Mainland}

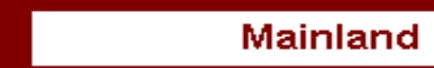

The reasonable commercial purpose principle evolved ever-more reaching from 2008 's article 120 of the tax rules to the 2015 tax Bulletin 7
Hong Kong

Started with a complex 7 part test for allowing a offshore transaction, with cases like Ngai Lik Electronics significantly weakening the principle in practice.

Our twenty-first recommendation thus consists of introducing a legitimate economic purpose test into Hong Kong's tax code, listing rules and in financial service provider/intermediaries' risk profiles. Section 61 of the Inland Revenue Ordinance allows the tax authorities to assess extra taxes for "any transaction which reduces or would reduce the amount of tax payable by any person [if] artificial or fictitious." ${ }^{342}$ The three sub-articles basically apply a legitimate economic purpose test by targeting "transactions designed to avoid liability for tax" (article 61a), "utilization of losses to avoid tax" (section 61b) and "Avoidance arrangement of no effect" (section 61c). ${ }^{343}$ Making such a legitimate economic purpose test more explicit in those articles would help ensure that businesses understand the logic behind the prohibitions contained in those articles. Similarly, any intermediary transacting with a company whose structure obviously lacks a legitimate economic purpose (like a manufacturer or service provider incorporated in the Bahamas) clearly should represent a higher commercial risk. ${ }^{344}$ The listing rules should furthermore require a local incorporation or incorporation in the jurisdiction where the listed company makes and/or sells its goods and services. ${ }^{345}$

Hong Kong's comply-or-explain culture of corporate governance provides a superiour way of dealing with these problems than approaches like the US of simply outlawing certain types of behaviour. For years, progressive US lawmakers have sought to outlaw shell companies. ${ }^{346}$ Indeed, several studies summarised by Morriss and Henson, show that many of Hong Kong's offshore partner jurisdictions (like the BVI) do not have lax regulations. ${ }^{347}$ Instead, foreign companies would have additional comply-or-explain requirements based around its conduct in its

\footnotetext{
${ }^{342}$ Inland Revenue Ordinance, sec. 61, 1986/2012, available online.

${ }^{343} \mathrm{Id}$.

${ }^{344}$ Many experts have documented the risks of transacting with offshore entities - in the lack of recourse to certain laws (like bankruptcy law) and anonymity which stifles accountability. See Global Witness and Global Financial Integrity, Chancing It: How Secret Company Ownership is a Risk to Investors, 2016, available online.

${ }^{345}$ Even if the exchange and companies do not completely adhere to the rule, at least the jurisdictions of incorporation will show more variation than at present (as shown in figure 59). For a look at the US's offshoreincorporated listed firms, see SEC, Foreign Companies Registered and Reporting with the U.S. Securities and Exchange Commission, 2014, available online.

${ }^{346}$ Wayne, Leslie, Stars start to align for bill to outlaw shell corporations, ICIJ Global Muckraker 2014, available online.

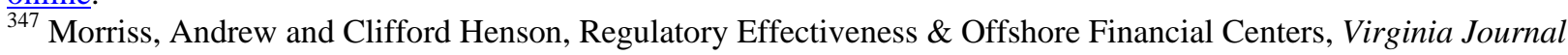
of International Law 53(2), 2013, available online.
} 
home market/jurisdiction of incorporation. ${ }^{348}$ Indeed, Luo and Steven E. Salterio find that comply-or-explain regulatory schemes boost market valuations more than other types - showing the wider value of this approach. ${ }^{349}$ Thus, maybe Hong Kong's code of corporate governance (and its disclose-or-explain rules) provides the best framework for regulating disclosures around these offshore incorporated entities.

Our twenty-second recommendation deals with incorporating the legitimate economic purpose concept into Hong Kong's code of corporate governance. As we have shown, complex and opaque offshore structures harm shareholder value and allow poor corporate governance practices to abound. ${ }^{350}$ If such offshore structures actually produce real and substantial benefits, these companies should explain them to the public - as required by Hong Kong's code of corporate governance. ${ }^{351}$ Indeed, such disclosures may well help academics and policymakers better understand the benefits of allowing such offshore incorporations. ${ }^{352}$

Recommendation 21: Introduce an explicit "legitimate economic purpose test" in article 61/61a into the Inland Revenue Ordinance (during the next major legal revision), in offshore listings, and in risk profiling clients/partners.

Recommendation 22: Add a provision to the Hong Kong Code of Corporate Governance requiring companies to confirm that the jurisdiction they have incorporated in matches the firm's economic purpose, or explain why not.

Other innovations in tax law might help inspire changes to the broader legal framework in the fight against corporate maladministration. Notably, Hong Kong's adoption of anti-abuse doctrines in its tax sphere might usefully serve to promote better corporate governance in the listing sphere. Hong Kong is a member of an OECD group working on regulations designed to stop treaty abuse that Mossack Fonseca's clients exploited so widely. ${ }^{353}$ That forum uses the term

\footnotetext{
${ }^{348}$ HKEx, What is "comply or explain"?, 2016, available online.

${ }^{349}$ Yan Luo and Steven Salterio, Governance Quality in a "Comply or Explain" Governance Disclosure Regime, Corporate Governance: An International Review 22(6), 2014, available online.

${ }^{350}$ Numerous academic studies find that shareholders would balk at offshore incorporations if given the chance. Such results confirm our own conclusions - as such incorporations can kill shareholder value. See Johnson, Holub, Questioning Organizational Legitimacy: The Case of U.S. Expatriates, Journal of Business Ethics 47(3), 2003, available online.

${ }^{351}$ A number of academics argue in favour of leaving offshore incorporations unregulated. Yet, if disclosure and transparency help markets to work better, these authors should not object to full public disclosure of the benefits these offshore structures endow. See Fisch, Jill, Leave It to Delaware: Why Congress Should Stay out of Corporate Governance, Delaware Journal of Corporate Law 37, 2013, available online. See also Kamar, Ehud, Beyond Competition for Incorporations, Georgetown Law Journal 94, 2006, available online.

${ }^{352}$ We understand very poorly the benefits of offshore incorporation (besides the obvious tax benefits). For a discussion of this lack of understanding, see Buckley, Peter, Dylan Sutherland, Hinrich Voss, Ahmad El-Gohari, The Economic Geography of Offshore Incorporation in Tax Havens and Offshore Financial Centres: The Case of Chinese MNEs, Journal of Economic Geography 15(1), 2015, available online.

${ }^{353}$ The G20/OECD Base Erosion and Profit Shifting Project has developed common regulations aimed at reducing the tax loopholes which incentivize poor corporate governance on the Mainland as elsewhere. See OECD, BEPS Actions, 2016, available online. For a list of members, see OECD, Inclusive Framework Composition: BEPS Members, 2016, available online.
} 
Principal Purpose Test as a rough equivalent to the reasonable commercial purpose test we described previously. ${ }^{354}$ Yet, at present, the Securities and Futures Commission's authorisation for companies incorporated abroad to list and transact in Hong Kong depends more on rulefollowing rather than the actual purpose and result of these rules. ${ }^{355}$ As the SFC's Joint Policy Statement regarding the listing of overseas companies from September 2013 notes, the "Listing Rules require an overseas company to demonstrate that its jurisdiction of incorporation has shareholder protection standards at least equivalent to those of Hong Kong. If this is not possible, overseas companies can achieve equivalent standards by varying their constitutive documents to provide them" (underlining ours). ${ }^{356}$ For the BVI specifically, the HKEx Country Guide finds in granting authorisation for BVI companies to list in Hong Kong, that "we do not consider BVI's shareholder protection standards to be materially different to our own." 357 As described in Figure 61, the HKEx (and SFC for that matter) have broad discretion over the recognition of foreign corporate governance and other standards. They do not describe the extent to which risk assessment (rather than simple compare-and-contrast of law) plays a role in determining who can list.

\section{Figure 61: Who Empowers the Exchange to Regulate Foreign Companies Listed in Hong Kong?}

Where does the Hong Kong Stock Exchange's authority to regulate foreign-listed companies come from? This so far academic question has practical applications if Hong Kong is to adopt more corporate-governance-friendly listing rules covering foreign companies (especially from the Mainland). The Securities and Futures Ordinance gives the Securities and Futures Commission the power to deal with foreign regulators and authorities.* A Memorandum of Understanding delegates that authority to the Hong Kong Stock Exchange to regulate day-to-day listing matters and trading.** Yet, just how far does that authority extend? Can the Exchange travel to these companies abroad and make determinations about corporate governance-related matters? Do certain types of SFC agreements with foreign authorities represent 'international relations?' (a political question to be sure) as prohibited in Hong Kong's Basic Law.

\footnotetext{
${ }^{354}$ In that context, lawmakers seek to regulate the holding companies whose structures muddy corporate relationships and reduce transparency to the outside work. See Juliana Dantas, Henny Verboom and Stephan Behnes, BEPS action 6: Preventing treaty abuse - a threat to holding structures? 2016 available online.

${ }^{355}$ For a list of countries (and the extra rules needed for each), see SFC, List of Acceptable Overseas Jurisdictions, 2016, available online.

${ }^{356}$ See SFC and HKEx, Joint policy statement regarding the listing of overseas companies, 2013, available online.

${ }^{357}$ See HKEx, Country Guide - British Virgin Islands, 2014, available online.
} 
Where does the Hong Kong Stock Exchange's authority to regulate foreign-listed companies come from? This so far academic question has practical applications if Hong Kong is to adopt more corporate-governance-friendly listing rules covering foreign companies (especially from the Mainland). The Securities and Futures Ordinance gives the Securities and Futures Commission the power to deal with foreign regulators and authorities.* A Memorandum of Understanding delegates that authority to the Hong Kong Stock Exchange to regulate day-to-day listing matters and trading.** Yet, just how far does that authority extend? Can the Exchange travel to these companies abroad and make determinations about corporate governance-related matters? Do certain types of SFC agreements with foreign authorities represent 'international relations?' (a political question to be sure) as prohibited in Hong Kong's Basic Law.

We do not have the space to do a full analysis here. Tradition has clearly sided with the HKEx imposing these rules.*** Why does the authority to recognise other jurisdictions' corporate governance standards fall to the SFC and the HKEx? Why don't foreign companies listed on the exchange have so few rights to take decisions about the Exchange and its policies when they constitute over $40 \%$ of listing companies? Why does listing in Hong Kong give the Hong Kong government the right to determine the corporate governance standards of foreign companies operating in foreign jurisdictions? While we base our recommendations on the common understanding of existing law, the legal purist may feel very uneasy with the authority the HKEx (and even the SFC) use to justify regulating foreign companies listed in Hong Kong.

* Securities and Futures Ordinance at 5(1.h) available online

** Memorandum of Understanding Regarding Listing Matters, at 2.4 available online.

*** The Hong Kong Stock Exchange represents one of the Hong Kong Exchanges and Clearing Limited's subsidiaries.

The Panama Papers experience teaches us that the Exchange should regulate the practices of shareholder protection rather than simply standards. Clearly, the legitimate economic purpose test and anti-abuse provisions we discussed previously focus more on intent and action - rather than just written regulations and policies. The SFC and HKEx should focus more on practice in foreign jurisdictions and by foreign companies than on their printed policies. The easiest way to introduce such changes into the way we relate to (and regulate) companies' behaviour abroad consists of amending the Joint Statement, so that the second paragraph reads:

"Listing Rules require an overseas company to demonstrate that its jurisdiction of incorporation has shareholder protection standards and practices at least equivalent to those of Hong Kong. If this is not possible, overseas companies can achieve equivalent standards and practice by varying their constitutive documents as well as governance and enforcement practices to provide them” (bold ours). ${ }^{358}$

\footnotetext{
${ }^{358}$ SFC and HKEx, Joint policy statement regarding the listing of overseas companies, 2013, at para 2, available online. The bold words and phrases represent our suggested additions.
} 
What kind of jurisdiction/company characteristics might attract limitations on foreign companies' listings or rights to conduct business in Hong Kong? The Panama Papers pointed to four practices in particular that undermine corporate governance in the wider business environment. ${ }^{359}$ First, rules that allow or encourage mailbox company colonies (or large numbers of corporations based out of a mail centre or building in which none of these companies' economic activity occurs. ${ }^{360}$ Second, rules requiring foreign-only operation of companies (namely companies incorporated in a particular jurisdiction are forbidden from operating in that jurisdiction). ${ }^{361}$ If these jurisdictions consider the company unfit to operate within their borders, why would they consider them more fit to operate abroad? Third, domestic rules allow for directors meetings with individuals who have no knowledge of the companies they supposedly govern and shareholder meetings conducted as a formality without any important company policies or decisions being discussed. Fourth, rules that allowing for the sale and subsequent operation shelf companies - as these shelf companies obviously had no legitimate economic purpose when incorporated. These rules have traditionally corresponded with companies having poor/little actual corporate governance and provide ways for corruption and fraud to undermine corporate governance in larger, more established companies on the Mainland and elsewhere. ${ }^{362}$

Naturally, shell and shelf companies pose significant risks to corporate governance in Hong Kong and outside. ${ }^{363}$ If judged by media reports, the dire current situation begs for additional regulation. These reports claim that $40 \%$ of the 22 companies listed on Hong Kong's stock exchange (on the main board) for the three month period ending in February 2016 consisted of shell companies. ${ }^{364}$ Share price volatility of these listed shell companies make the harms to equity markets and corporate governance in general obvious - with 56 companies' valuations increasing by more than $1,000 \%$ between 3013 and 2015, despite 39 of them losing money. ${ }^{365}$ Few can document the corporate governance practices of many shell companies that have other

\footnotetext{
${ }^{359}$ Alibaba (a Chinese technology company) illustrates the risks and potential harms of non-transparent governance of an offshore incorporation entity. See Lin, Yu-Hsin and Thomas Mehaffy, Open Sesame: The Myth of Alibaba's Extreme Corporate Governance and Control, Brooklyn Journal of Corporate, Financial \& Commercial Law 10, 2016, available online.

${ }^{360}$ Numerous stories and studies have shown that these mailbox company colonies aim to avoid taxation rather than to enable more productive corporate operations. For a recent case where authorities required changes to complicated governance structures, see Drucker, Jesse and Jeremy Kahn, U.K.'s Tax Deal With Google Wasn't Just About Offshore Havens, Bloomberg February, 2016, available online.

${ }^{361}$ Under the International Business Companies Act, BVI companies are "ring fenced" - meaning they can not conduct business domestically. Numerous studies show the harms of these provisions. See Schjelderup, Guttorm, Secrecy jurisdictions, International Tax and Public Finance 23(1), 2016, available online.

${ }^{362}$ Williams explains why authorities like Hong Kong's need to focus on regulatory consequences as well as conduct-effects. -- as offshore financial centres modify their financial services to avoid tightening regulation worldwide. The only successful approach, in light of such market adaptation, requires moving away from looking at paper rules. See Williams, Thomas, International Pressure Makes Offshore Lawyers Change Tack, International Financial Law Review 21(24), 2002, available online.

${ }^{363}$ We do not have space to list these harms. See Global Financial Integrity and Global Witness, Chancing It: How Secret Company Ownership is a Risk to Investors, 2016, available online.

${ }^{364}$ See Yam, Shirley, Hong Kong's Red-Hot Corporate Shell Game is Cause for Concern. South China Morning Post February, 2016, available online.

${ }^{365}$ Robertson, Benjamin, Jeanny Yu and Eduard Gismatullin, The Magical Transformation of Hong Kong's Listed Companies, Bloomberg July, 2016, available online.
} 
shell companies as directors and shareholders. ${ }^{366}$ Hong Kong's disclosure regime should thus include shell companies, special purpose vehicles and the companies that work with them.

Hong Kong's code of corporate governance should introduce a special section for offshore, shell/shelf, special purpose vehicles and conduit companies. Numerous studies have documented both the good and bad sides of using these kinds of structures. ${ }^{367}$ Most authors argue that regulators should not try to "fix" these structures - but rather increase their transparency. ${ }^{368}$ Requiring that special purpose vehicles have a unique designation (like SPV rather than Ltd. or Inc.) can help ensure parties understand the nature of the entity they do business with. If these entities truly are companies, then why do they not issue the same large corporate governance reports as the traded entities that use them? Numerous studies have described how to modify accounting and reporting procedures for these entities. ${ }^{369}$ The following four recommendations thus keep in line with Hong Kong’s policy directives aimed at increasing disclosure and transparency.

Recommendation 23: Introduce rules in the Listing Rules companies from jurisdictions (or companies which transact with them) which require additional due diligence and a classification as a high risk entity if that company's jurisdiction allows or encourages: a) mailbox company colonies, b) foreign-only operation and c) directors and shareholder meetings with individuals having little knowledge of the companies they affiliate with, and d) sale and operation of shelf companies.

Recommendation 24: Introduce a provision in the Code of Corporate Governance to require companies conducting any transactions with a shell company, offshore company from the BVI, Cayman Islands, Bahamas, or other jurisdictions decided by the HKEx to disclose such business and the nature of that business.

Recommendation 25: Require SPV at end of company name (like Limited) to designate that the entity is a special purpose vehicle.

Recommendation 26: Require offshore, shell/shelf, special purpose vehicles, and "hollow" holding companies to issue corporate governance reports outlining their operations in the same way that normal companies do.

\footnotetext{
${ }^{366}$ Zarroli, Jim, Want To Set Up A Shell Corporation To Hide Your Millions? No Problem, NPR April, 2016, available online.

${ }^{367}$ Ahlawat and co-authors in particular describe the pros and cons of these structures, along with their lack of transparency, particularly well. See Ahlawat, Sunita, Danielle Bolomo and Ky1e Ropp, Whether Sensible Business Tool or Deceptive Scheme to Conceal, the Special Purpose Entities Are Here to Stay, Accounting and Finance Research 3(2), 2014, available online.

${ }^{368}$ Newman in particular represents one voice in this camp. See Newman, Neal, Enron and the Special Purpose Entities-Use or Abuse-The Real Problem-The Real Focus, Law and Business Review of the Americas 13, 2007, available online.

${ }^{369}$ Our paper - focused on corporate governance - does not try to discuss the accounting and reporting rules around these entities. For more, See Basel Committee on Banking Supervision, International Organisation of Securities Commissions, and International Association of Insurance Supervisors, Report on Special Purpose Entities, 2009, available online.
} 


\section{Updating China's Code of Corporate Governance and Other Regulations}

Many studies we have already reviewed have argued that Chinese corporate governance would improve only if China's rules improved. Foreign listings of Chinese companies supposedly import foreign corporate governance rules. ${ }^{370}$ Many of these companies incorporate offshore making offshore incorporations a key part of this import process. ${ }^{371}$ We previously dispelled the notion that Chinese companies can import "better" corporate governance rules. Yet, no one can deny that some corporate governance rules help improve companies' market valuations more than others. Figure 62, for example, shows the way that Chinese market valuations have changed in response to the valuation of their American Depository Receipts (ADRs). ${ }^{372}$ Offering access to Chinese companies' shares in the US has significantly more effects on Mainland companies' market values than offering such access in Hong Kong or Taiwan. Even if Mainland companies embraced Hong Kong's corporate governance rules, such rules do not improve companies market valuations as much as US corporate governance rules.

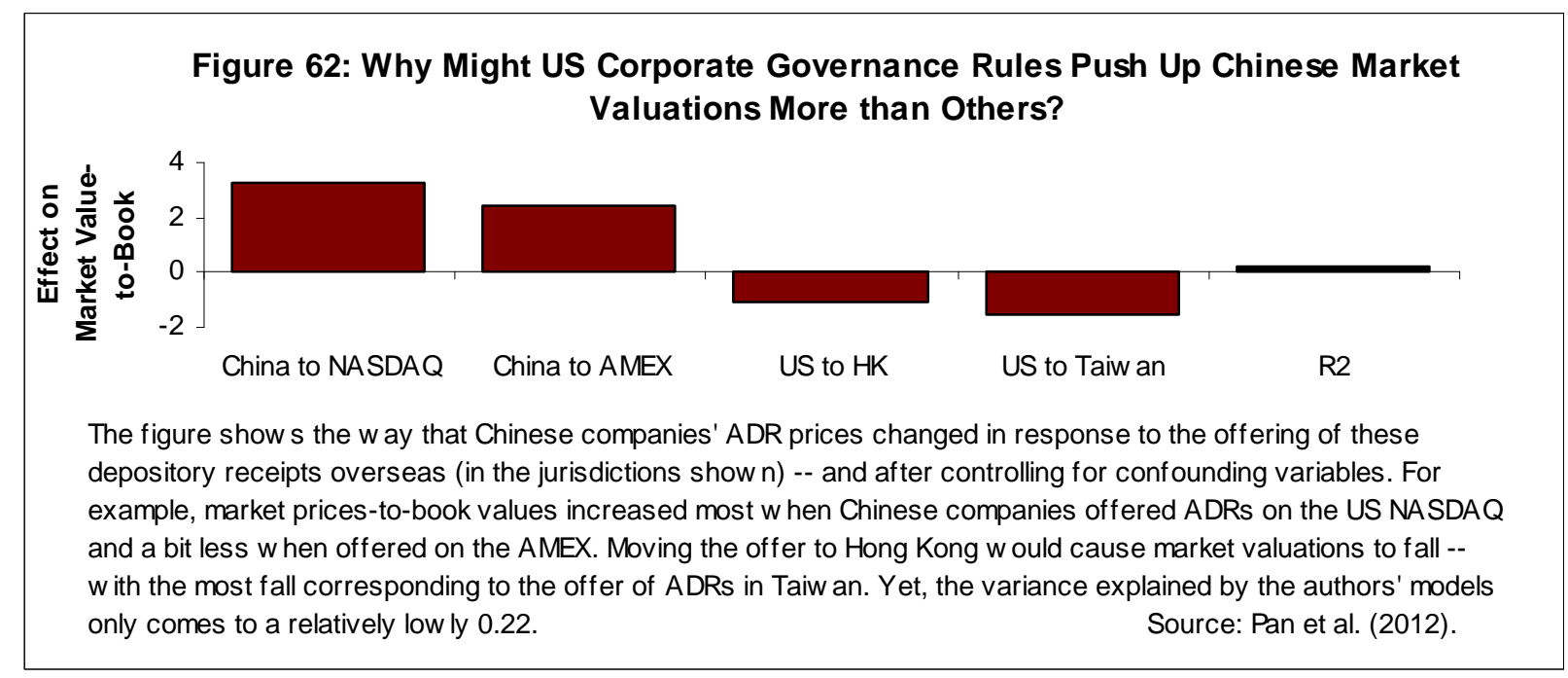

How have Mainland corporate governance rules adapted to changing markets and growing access to foreign exchanges? China's corporate governance regulations - as well as corporate governance itself -- have improved by leaps and bounds since the 2002 publication of its Code of Corporate Governance. ${ }^{373}$ Yet, by senior officials' own admission, China's corporate governance regulations should improve far more in a wide-array of ways. Figure 63 shows the most

\footnotetext{
${ }^{370}$ To take another example, Sun and Tobin argue that Bank of China's cross-listing in Hong Kong helped promote convergence of its corporate governance. Yet, they provide no evidence - listing data on financial performance instead. See Sun, Lai-Xiang and Damian Tobin, Corporate Governance Reform and International Listing: Case of the Bank of China (Hong Kong), Centre for Financial and Management Studies Discussion Paper, 2003, available online.

${ }^{371}$ The British Virgin Islands in the Bank of China case cited in the main body of this paper. See Id at Figure 1.

${ }^{372}$ Pan, Lee-Hsien, Chien-Ting Lin , and K.C. Chen, ADR Characteristics and Corporate Governance in the Greater China Region, Review of Development Finance 2, 2012, available online.

${ }^{373}$ See China Securities Regulatory Commission, Code of Corporate Governance for Listed Companies in China, Zhengjianfa No.1 of 2002, 2002, available online.
} 
important areas recently identified by senior Chinese officials themselves. ${ }^{374}$ Disseminating a revised code of corporate governance probably represents the easiest task to accomplish. While not as important as some of the structural problems identified, lack of anti-fraud and whistleblowing programmes also represents an easy, but important, activity to promote at the China-Hong Kong level. Similarly, supervisors on the Mainland can call upon Hong Kong's fraud and compliance community for training and support. Requiring independent directors to show up (easy) and vote their mind (much harder) represents another important and relatively easy activity.

\section{Figure 63: Introducing a Consolidated Code of Corporate Governance Probably Easiest Out Of All Chinese Self-Admitted Corporate Governance Defects}

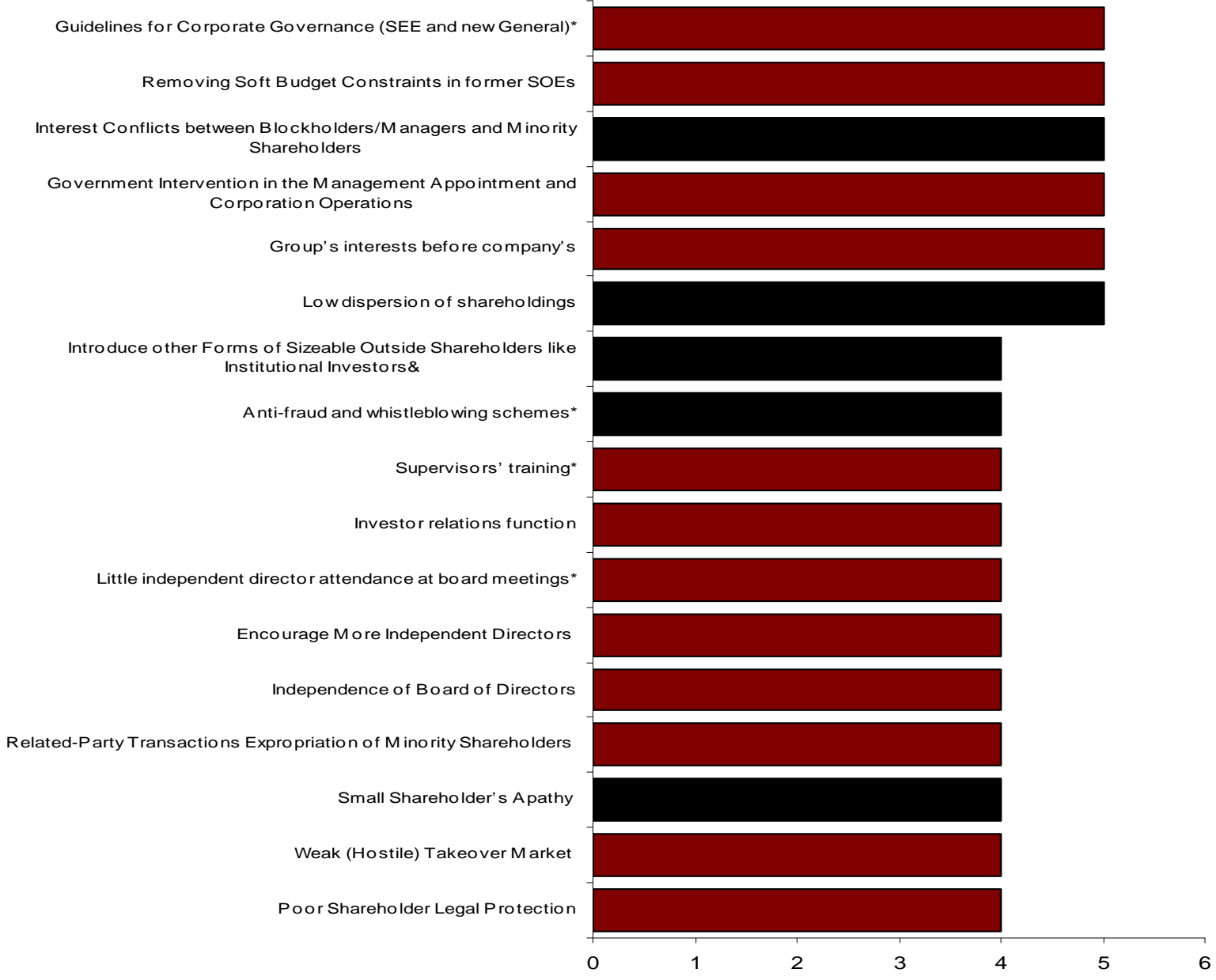

The figure shows the activities identified by Chinese officials to improve the Mainland's corporate governance. Hong Kong has already developed significant experience in tackling most of these issues.

* represents an easy activity (1-3)

black bars represent an activity which Hong Kong has yet to master itself.

${ }^{374}$ For example, see Hu, Ru-Yin, Efforts to Improve Corporate Governance in China, OECD Conference on the Corporate Governance of State Owned Enterprises, 2015, available online. See also Protiviti (2013) at Tables 2 and 3. 
The scattering of corporate governance provisions across legislative or administrative instruments hinders Chinese directors and corporate stakeholders from understanding corporate governance obligations and best practices. The legislative acts containing corporate governance provisions include the 2006 Company Law (mainly about shareholder protection and board structure), the 2006 Securities Law (mainly governing investor protection and disclosure), the 2006 Criminal Law Amendment Act (mainly fraud, insider trading and non-compliance with other regulations), the 2009 Law on the State-Owned Assets of Enterprises (regulating mainly how state owned enterprises should behave), and the 2000 Accounting Law (ensuring accurate financial reporting and oversight). ${ }^{375}$ Other peripheral rules include the 2007 Regulations on Listed Companies' Information Disclosure, the 2006 Guidance on Listed Companies’ Articles of Association, the 2006 Rules on Listed Companies' Shareholders’ Meetings, the 2001 Guiding Opinions on the Establishment of the System of Independent Directors in Listed Companies, the 2004 Provisions on Strengthening the Protection of the Rights and Interests of Public Shareholders, the 2006 Regulations on the Takeover of Listed Companies, the 2008 Regulations on Major Asset Reorganisation of Listed Companies, the 2005 Regulations on Equity Incentives of Listed Companies, the 2006 Regulations on the Registration and Settlement of Securities and the 2008 Basic Standard for Enterprise Internal Control. ${ }^{376}$ We could not find the rules governing Articles of Association of Companies Seeking a Listing outside the PRC Prerequisite Clauses at all. We do not discuss specific corporate governance rules focused on securities/financial firms. ${ }^{377}$

What is the extent of such scattering? As shown in Figure 64, companies need to consult at least 7 laws in order to assess the extent to which they comply with the OECD Corporate Governance Principles. As shown, the Company Law contains most of the relevant provisions. Yet, the official code of corporate governance applies to only about $15 \%$ of the relevant provisions. Such dispersion complicates managers' ability to draft relevant corporate governance decisions and internal auditors' ability to check them. Obviously problems must exist - given the poor governance performance of the Mainland's companies. As noted previously, on a 5 point scale of improvement, none of the areas of corporate governance tracked improved by 3 points or more. ${ }^{378}$ The time has come to consolidate China's Code of Corporate Governance - using improvements to Hong Kong's own corporate governance rules as an example.

\footnotetext{
${ }^{375}$ We take these laws from Yang and co-authors. See Yang, Hua, Zehua Ouyang, Li-Xin Zhao, Jian-Chun Cai, Qian-Song An, Bo-Jin Yan, Yan Liu, Ming Huang, Wei-Dong Zhang, Chun-Sheng Pan, Huan Zhu, Li Gao, XingHui Jiang, Hong-Xia Sun, Xue-Yue Jiang, Zhao-Hui Chen, Jian-Shan Huang, Xu Yong, Shun-Ying Ren, Jiang-Xuan She, Wei Ren, and Hong-Da Zhou, Corporate Governance of Listed Companies in China: Self-Assessment by the China Securities Regulatory Commission, 2011, available online.

${ }^{376}$ We do not link to all of these - as they are mostly peripheral to our discussion. For readers interested in these rules, and the institutional system generating them, see Shi, Chen-Xia, Political Determinants of Corporate Governance in China, 2012.

377 See CSRC, Provisional Code of Corporate Governance for Securities Companies, 2004, available online.

${ }^{378}$ CFA Institute, China Corporate Governance Survey, 2007, available online.
} 


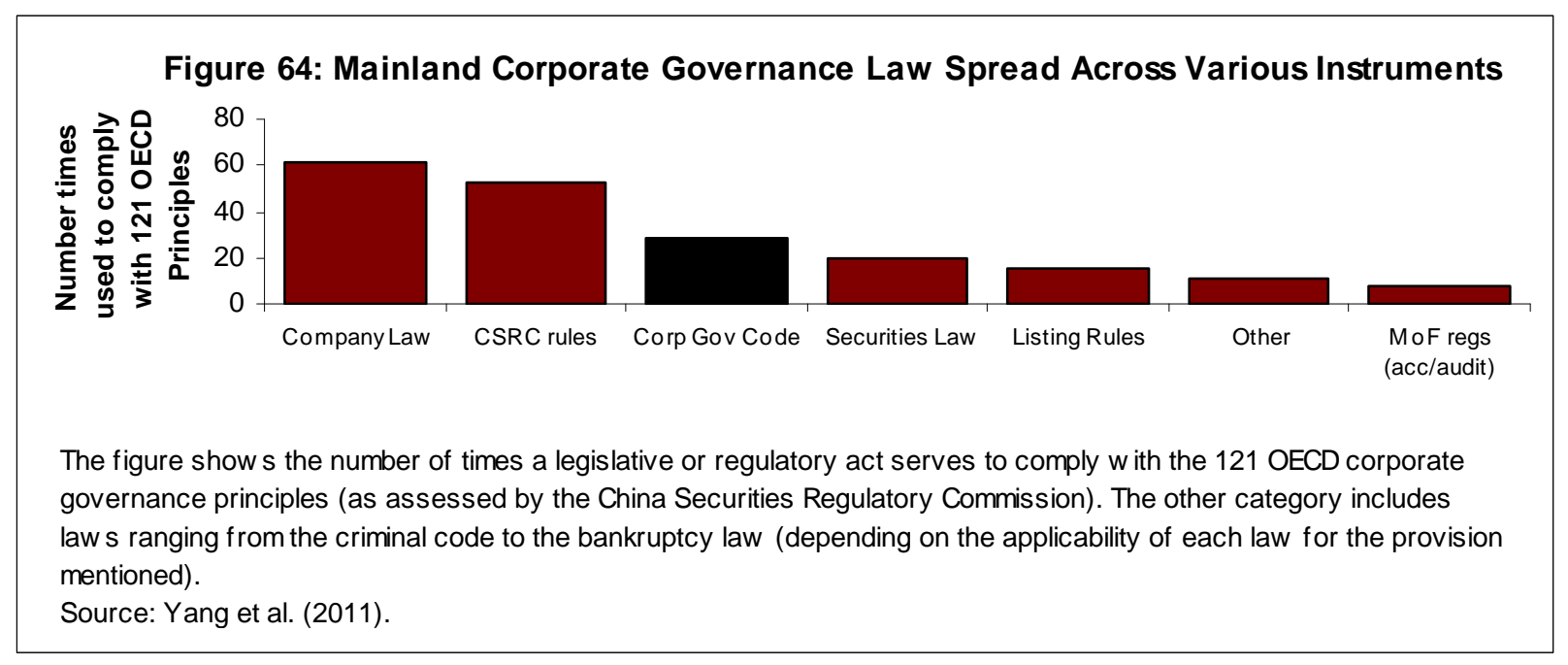

Hong Kong's business sector and regulators would need to exert a fair amount of influence in order to encourage the drafting of a revised Mainland code of conduct. Perhaps the best import from Hong Kong's corporate governance regime consists of its long history of using principlesbased regulation. Figure 65 shows the principles enshrined in the Chinese Code of Corporate Governance ${ }^{379}$ Defining some terms like "damage”, “necessary means” or interference” remain uncontroversial - and indeed similar in Hong Kong's code. Yet, three principles in particular look very difficult to interpret in a Mainland context. First, particularly Section 2 of Chapter 2's the Independence of Listed Company stipulates that, "controlling shareholders shall respect the financial independence of the company and shall not interfere." ${ }^{380}$ The obvious question arises about the extent to which government officials and state-owned entities serving as controlling shareholders can (or should) refrain from directing and interfering in these companies. We have already pointed to the social mandate given to China's companies - both state-owned and private. Second, Chapter 7(3) covers the declaration of beneficial ownership in Mainland companies. The section requires the declaration to shareholders of persons who a) own a comparatively large percentage of shares of the company, b) actually control the company when acting in concert, c) change their shareholding (and/or factors causing such changes), d) pledge the company's shares, and/or e) transfer control of the company. ${ }^{381}$

\footnotetext{
${ }^{379}$ China Securities Regulatory Commission, Code of Corporate Governance for Listed Companies in China, Zheng Jian Fa No.1 of 2002, 2002, available online.

${ }^{380}$ Several articles in the section contain this formulaic phrase.

${ }^{381}$ The declaration to shareholder probably constitutes a minimum standard. When viewed in combination with Chapter 6 and 7.1, one could claim that such information sharing can extend beyond shareholders to the wider community of the firms' stakeholders.
} 


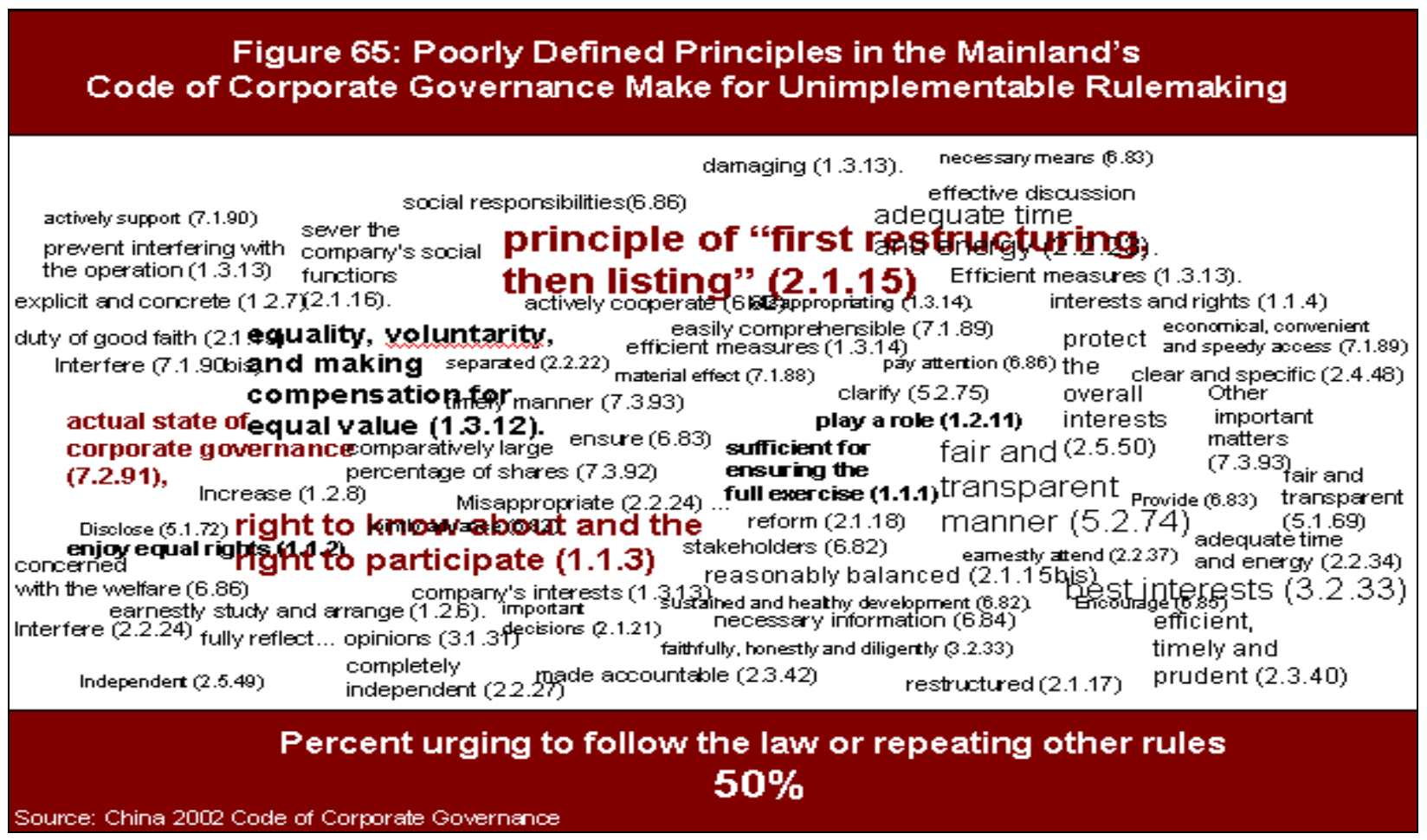

Other principles contained in the code of corporate governance also look relatively difficult to understand in the paradigm of Hong Kong's corporate governance. Chapter 6 of the Code looks suspiciously like the socialist regulation which the government has supposedly tried to roll-back for decades. Article 86 admonishes companies to consider the "welfare, environmental protection and public interests of the community in which it resides, and ... pay attention to the company's social responsibilities.” ${ }^{382}$ Would these principles still apply if the company worked offshore? How might harmonisation with Hong Kong's own code of corporate governance affect provisions like those in Article 86?

We recommend three activities which Hong Kong's Financial Services Development Council could easily implement. ${ }^{383}$ First, consolidating the corporate governance related provisions from China's various legal instruments could take little time, and serve as an offering to companies at home, on the Mainland and elsewhere. Second, the Council could provide guidance on the principles enshrined in the Mainland code, as they see them. Naturally, such guidance would lack the Mainland government's authority or approval. Yet, the Guidance document would move Mainland regulators toward thinking in a more principles-focused regulatory environment. Third, encourage the CSRC to adopt provisions from Hong Kong's code which the Mainland version

\footnotetext{
${ }^{382}$ See China Securities Regulatory Commission, Code of Corporate Governance for Listed Companies in China, Zheng Jian Fa No.1 of 2002, 2002, available online.

Code of Corporate Governance

for Listed Companies

${ }^{383}$ We encourage the Financial Services Development Council to engage in this work - as they have the mandate and organisational structure. The Council's organisation consists of public and private sector bodies who can decide how to divide the work best among themselves. The mandate comes from the Council's objectives, and specifically objective 4 to "promote our financial services industry and Hong Kong as an international financial centre on the Mainland and overseas.” See FSDC, About Us: Objectives, 2016, available online.
} 
lacks. ${ }^{384}$ Naturally, not all provisions need to move over - only those encouraging the "bonding" of better corporate governance rules on the Mainland we already discussed. ${ }^{385}$ The FSDC seems like the only body with the gravitas to work with the Mainland authorities in this way.

Recommendation 27: The FSDC should consolidate the numerous CSRC, Company Law and other rules into unified rulebook (as a goodwill gesture).

Recommendation 28: The FSDC should provide non-authoritative Guidance from the Hong Kong perspective for principles outlined in the Mainland's 2002 Code of Corporate Governance.

Recommendation 29: The FSDC should encourage the CSRC to adopt relevant provisions from the Hong Kong Code of Corporate Governance to the Mainland's.

Yet, Hong Kong's government and/or businesses can hardly advise the Mainland when its own code of corporate governance needs fixing. Various assessments do not agree on Hong Kong's corporate governance ranking vis-a-vis other financial centres. ${ }^{386}$ Yet, all assessments do agree that Hong Kong's companies need to improve significantly their corporate governance and improvement would increase these companies' market values. Figure 66 shows the effect of economic effects on Hong Kong's own companies of increasing their corporate governance from the last known academic study on the question. ${ }^{387}$ Hong Kong firms which move from having low corporate governance scores to high scores experience an 11\% increase in market value, with decreasing amounts of risk (share price volatility). In their assessment of Hong Kong's corporate governance, Michael and Goo give 18 recommendations for improving corporate governance in Hong Kong. ${ }^{388}$ Hong Kong's corporate policies have the power to influence Mainland companies' governance and thus market valuations. ${ }^{389}$ Better corporate governance rules and practices in Hong Kong have the ability to influence these rules and practices on the Mainland. Yet, as noted in recommendation 30, Hong Kong's authorities and companies should adopt outstanding recommendations in order to improve Hong Kong's own corporate governance practices before thinking about using these rules to influence Mainland companies.

\footnotetext{
${ }^{384}$ Such work would likely serve the State Council's policy objectives defined in the 2005 Circular of the State Council on its Approval of the CSRC's Opinion on Improving the Quality of Listed Companies. We could not find an English-language version of this much-cited circular. We thus can not describe in more detail the government's/Party's long-term plans to improve corporate governance.

${ }^{385}$ Authors like Yu would clearly lament the wholesale adoption of Hong Kong's corporate governance rules on the Mainland. See Yu, Guang-Hua, Comparative Corporate Governance in China: Political Economy and Legal Infrastructure, 2007.

${ }^{386}$ For example, Hong Kong's corporate governance ranked second among selected financial centres according to the World Competitiveness Report in 2012 but sixth according to Governance Metrics International. See See Michael, Bryane and Say Hak Goo, Last of the Tai-Pans: Improving the Sustainability of Long-Term Financial Flows by Improving Hong Kong's Corporate Governance, University of Hong Kong Faculty of Law Research Paper No. 2013/039, 2013, at p. 8, available online.

${ }^{387}$ Yan-Leung Cheung, Thomas Connelly, Ping Jiang, and Piman Limpaphayom, Does Corporate Governance Predict Future Performance? Evidence from Hong Kong, Financial Management 40(1), 2011, available online.

388 See Michael and Goo, supra at p. 4-5.

${ }^{389}$ Such an observation represents nothing new. See Xiao-Huang and Horace Yeung, Chinese Companies and the Hong Kong Stock Market, 2014.
} 
Figure 66: Hong Kong Corporations with High Corporate Governance Scores Earned 11\% Higher Returns with Lower Risk

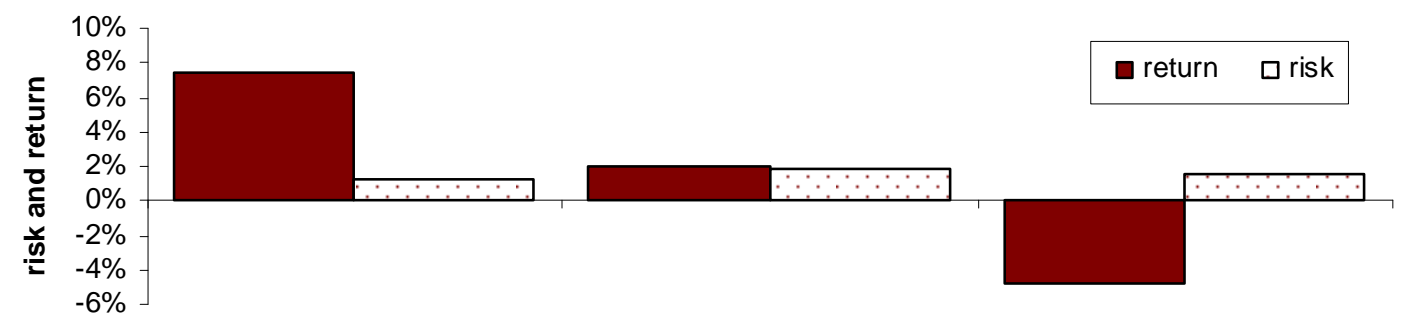

High CG Scores Medium CG Scores Low CG Scores

The data in the chart show the average 12-month abnormal cumulative average stock returns for three groups of Hong Kong companies sorted by their corporate governance index scores. In comparison, we show the standard deviations of market-market residuals for each of these groups (w hich proxies the risk of investing in these companies). Source: Cheung et. al. (2005) at Table 5.

Recommendation 30: Implement the recommendations of our last assessment of Hong Kong's corporate governance to tackle concentrated ownership, institutional activism, selfdealing, and Board development in Hong Kong itself.

\section{Creating Winners Among Chinese Share Investors and Compensating Hong Kong's Losers}

\section{Effects of Corporate Governance Changes}

What effect would adopting Hong Kong's better corporate governance policies and practices have on foreign - and particularly Mainland - firms? Hong Kong-listed Mainland companies’ share price changes might provide some clue. The last major revisions to Hong Kong's code of corporate governance occurred in 2011. ${ }^{390}$ The easiest way of guessing what the effects the revision of Hong Kong's code of corporate governance on Mainland firms had consists of looking at the differences-in-differences of their share prices. Namely, we looked at the difference in share prices for Mainland firms listed in Hong Kong from January 2011 to December 2012. Share prices from for Hong Kong firms listed on the Hong Kong stock market increased on average by $20 \%$ at a time when Mainland shares on the Hong Kong stock market fell by $11 \%$. $^{391}$ The $11 \%$ fall in Mainland companies' shares listed on the Hong Kong stock market partly explains that drop in the overall market index. Yet, such a drop pales in comparison to the 33\% drop in the overall Mainland share price index. ${ }^{392}$ The difference between Hong Kong and Mainland firms' difference in share prices from the beginning of 2011 to the end of 2012

${ }^{390}$ The HKICPA provides the background and content of that reform. As noted by the Hong Kong Exchange, the Exchange started consultations on reforming the corporate governance code in 2010, with implementation carrying on in 2012. See HKICPA, A Guide on Better Corporate Governance Disclosure, 2012, available online. See also HKEx, Consultation Paper on the Review of the Code on Corporate Governance Practices and Associated Listing Rules, December 2010, available online.

${ }^{391}$ Such an increase occurred against the backdrop of a 5.4\% drop in the S\&P Global Market Index tracking Hong Kong (as reported by the World Bank). See World Bank, S\&P Global Equity Indices (annual \% change): Hong Kong, 2016, available online.

${ }^{392}$ As we only want ball-park estimates for this paper, we do not disaggregate the Chinese markets into specific exchanges - like the Shanghai or Shenzhen exchanges. See World Bank, S\&P Global Equity Indices (annual \% change): China, 2016, available online. 
thus comes to around $31 \%$. Such a difference comes from the company-specific and policyspecific differences between Hong Kong and Mainland firms. Mainland firms listing in Hong Kong thus saved 22\% in losses - an effect we might call a Hong Kong listing effect. At that same time, Mainland firms experienced the changing corporate governance rules at a time when other companies around the world did not. These other companies share prices in the global S\&P index fell by $15 \%$. Thus, the specific effect of the corporate governance changes on Mainland firms after removing market specific effects - comes to $7 \%$. If the differences-in-differences methodology removed other effects, revisions to Hong Kong's code of corporate governance should have cased a $7 \%$ lift in Mainland share prices.

Extending on this logic, we can derive the value of corporate governance reforms on Mainland companies' market capitalisation. As we reported earlier, Mainland firms had a market capitalization of $\$ 8.2$ trillion and better corporate governance has the potential to add another $7 \%$ in share value. We can not know the extent to which the Mainland government's own efforts at corporate governance reform will increase share price valuations. If we assume that existing and planned corporate governance reform on the Mainland will translate into increases in market value of 3\%, then the remaining 4\% increase (times 8.2 trillion) equals roughly $\$ 330$ billion. Thus, radical changes to Hong Kong's corporate governance rules could increase market capitalizations on the Mainland by around $\$ 330$ billion by the time their effects work through these companies.

Changes to corporate governance rules would also affect these firms' riskiness and the distribution of share price gains between Mainland firms. Figure 67 shows the spread in share prices for Hong Kong listed firms' share prices in 2011 and in 2013. We have matched these price distributions to the closest fitting statistical distribution for these price changes (a log logistic curve). As shown, share prices between listed firms tightened after the code of corporate governance revisions. Such share price convergence should not surprise us -- as the expanded and standardized corporate governance regulations probably had the effect of reducing the variability of firm-specific differences in the governance practices which reflected on their share prices. Figure 68 though shows the dark side of such reforms. Compared with share price changes around the world, the share prices of many Mainland firms listed in Hong Kong dropped significantly. If we fit the tightest statistical distribution possible on the data, the resulting average price drop came out to around $20 \%$ more than world equity prices fell. Yet, when we take into account the larger share price gains of some companies (by fitting a normal distribution to the data), overall share prices rose by $7 \%$. These data confirm a trend repeated by so many corporate governance researchers. Corporate governance reform may increase share price values in the longer-run, even if many companies lose in the short-run. ${ }^{393}$

\footnotetext{
${ }^{393}$ Claessens as well as Black and co-authors might explain such dynamics due to short-term resistance by the entrenched owners and managers whose interests corporate governance reform may threaten. Indeed, commentators like Crawford note that corporate governance reform's whole purpose consists of getting managers to focus on the longer-term. See Claessens, Stijn, Corporate Governance and Development, World Bank Research Observer 21(1), 2006, available online. See Black, Bernard, Woochan Kim, Hasung Jang, and Kyung-Suh Park, European Corporate Governance Institute Finance Working Paper 103/2005, 2008, available online. See also Crawford, Rebecca, Corporate Governance Reform: How to Promote the Long-Term Health and Value of U.S. Corporations, NYU Journal of Law \& Business 5, 2009, available online.
} 

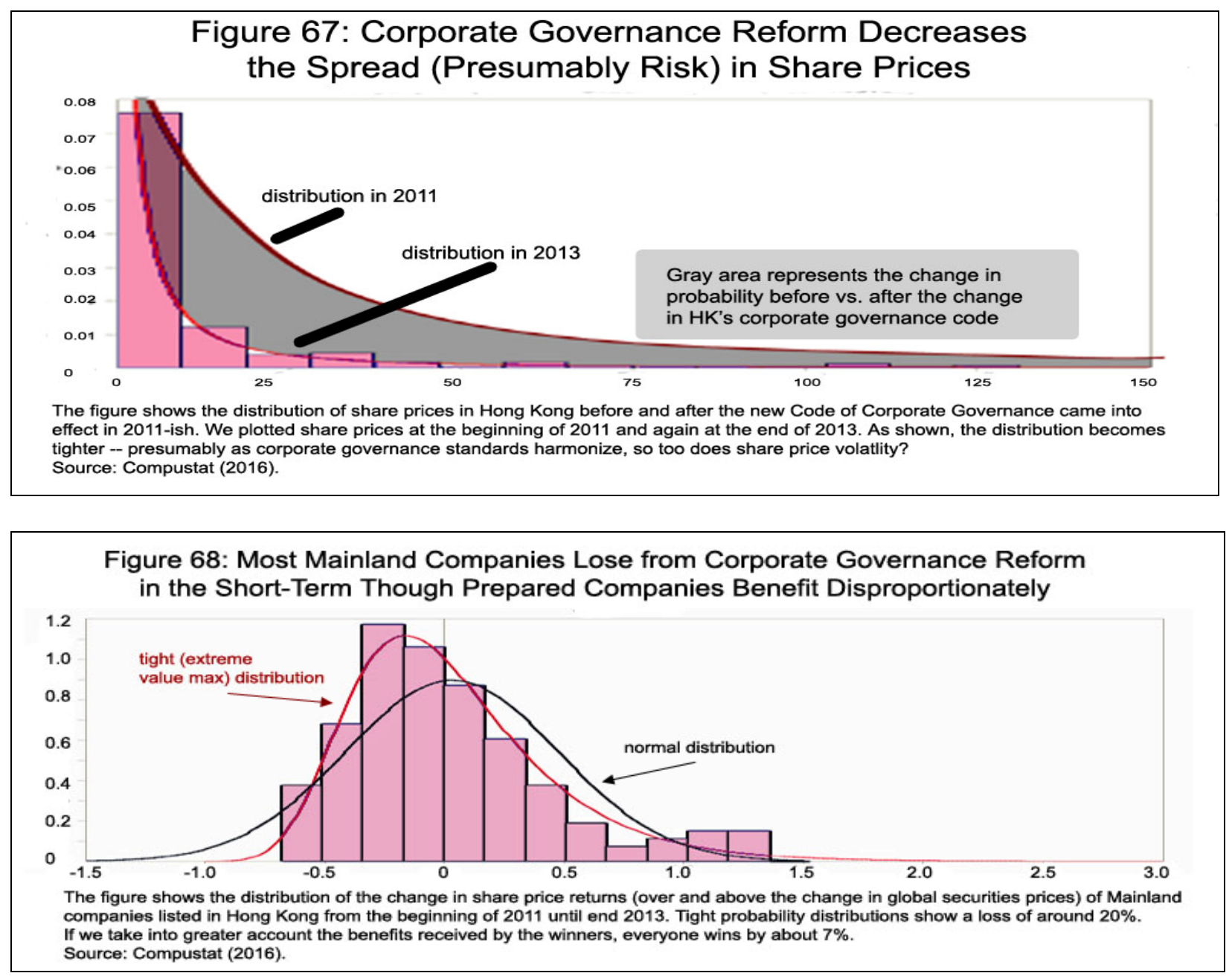

\section{Profitably Redirecting Hong Kong’s Incorporation Agents/Services Firms}

The evidence suggests that tightening incorporation rules and strengthening corporate governance would not radically affect the number of company registrations in Hong Kong. Figure 69 show the number of employees in the 1,100 incorporation, secretarial and corporate services firms registered by the Hong Kong Trade Development Council. ${ }^{394}$ Excluding outliers (the jumbosized global incorporation firms), most of these firms employ on average 10 people. ${ }^{395}$ Data from the Companies Registry moreover suggest that the large number of small agents detracts from incorporation market quality. Figure 70 shows the number of non-Hong Kong companies registered (and deceased) over the past several years in Hong Kong. ${ }^{396}$ Only about 65\% of these foreign company incorporations survive every year. We do not know which ones live and die, or

\footnotetext{
394 See HKTDC, Online Marketplace: Corporate Secretarial Service, 2016, available online.

395 Our sample size of twenty five firms in no way represents enough firms to make a reliable guess of the true average. Yet, given this probability distribution, these firms have less than a $5 \%$ chance of having an average of 20 or more employees.

${ }^{396}$ See Companies Registry, Registered Non-Hong Kong Companies in 2016, 2016, available online. See also Companies Registry, Number of Local Companies that has Remained Registered in the Companies Register since 2014 [Incorporated under the Companies Ordinance (Chapter 622)], 2016, available online.
} 
their average lifetime. ${ }^{397}$ Only about 6,300 summons for regulatory or other violations for over 1.3 million registered companies means that an incredibly low $0.5 \%$ of companies find themselves into the Company Registry’s cross-hairs in any year. Incorporation agents in Hong Kong thus seem ripe for industry consolidation - as more regulatory requirements force these firms to offer extra advisory services in the areas of compliance, corporate governance. The simple half-day one stop-shop incorporation will probably disappear.

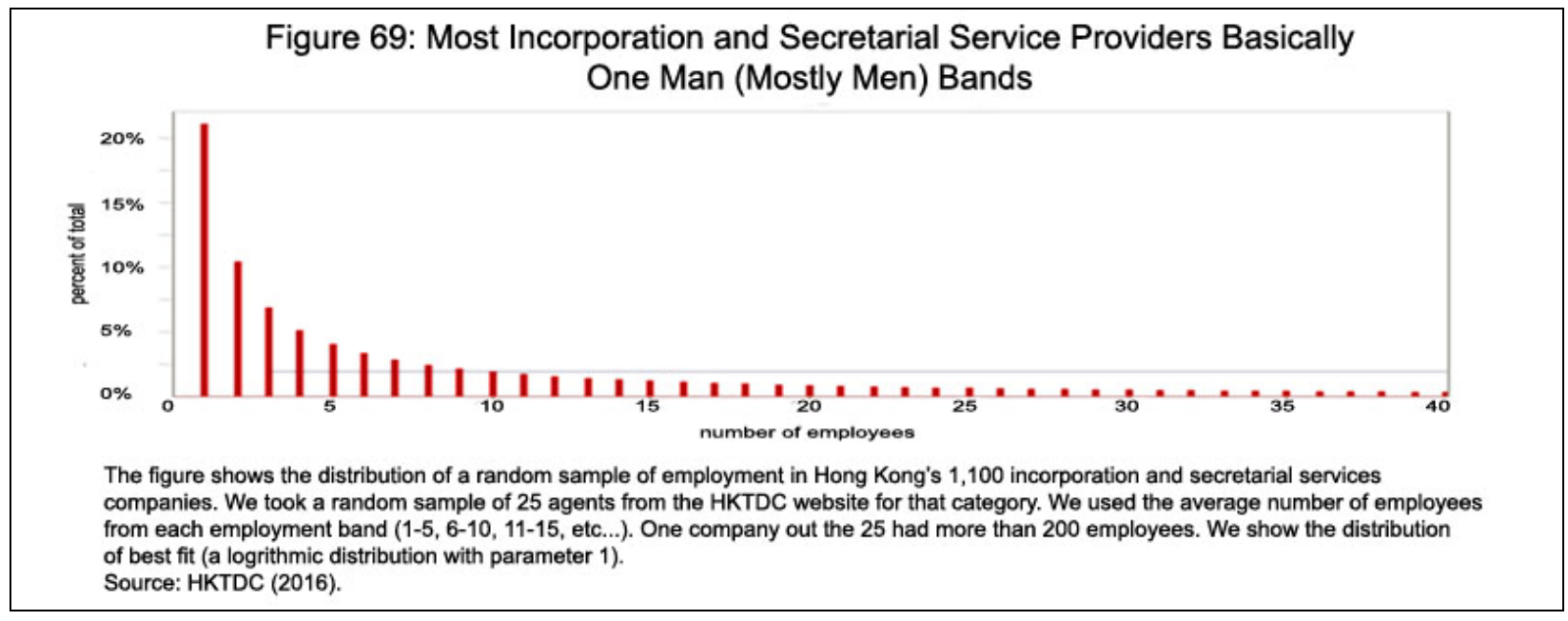

Figure 70: Only Roughly 65\% of Hong Kong's Incorporation Agents' Newly Incorporated Creations Stand the Test of Time?

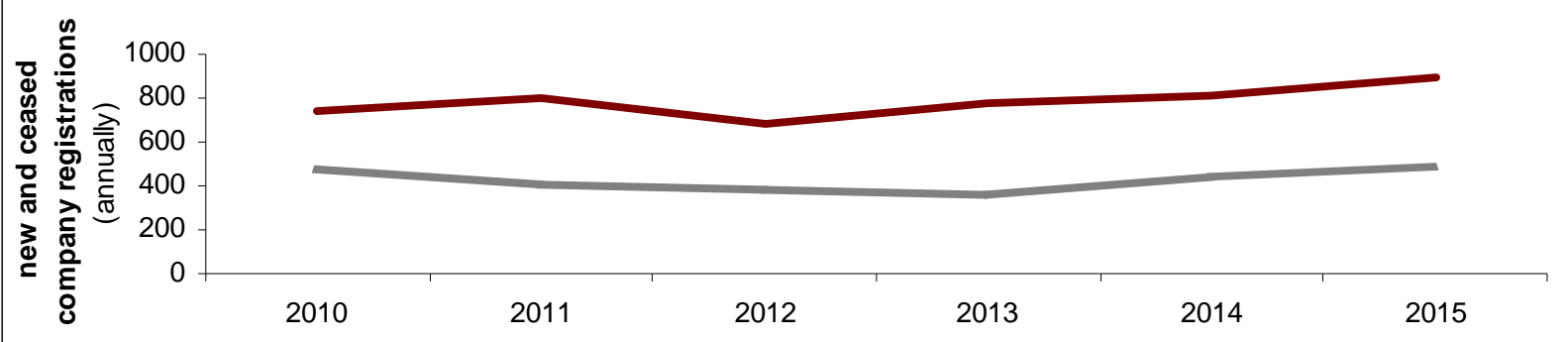

The figure shows the number of new versus ceased companies registered by Hong Kong's Companies Registry. Roughly $35 \%$ of the number of each years incorporations cease to have a place of business in that year. Of course, registration agents' companies may have better survival track records -- or worse. But if we use the overall statistic, such turn-over is unlikely due to creative distruction and market discovery of new and innovative ideas.

Source: Hong Kong's Company Registry (2016).

A cursory look at the data suggests that our proposals would cost Hong Kong's incorporation industry relatively little. Figure 71 shows the employment in, and estimated revenue from, Hong Kong's secretarial firms. ${ }^{398}$ Across the sector, these firms employ close to 10,000 people - a number which the Hong Kong Trade Development Council's (HKTDC’s) data roughly

\footnotetext{
${ }^{397}$ If these firms follow the global norm, long-lived firms tend to live longer, and newer firms disappear more often.

${ }^{398}$ See Corporate Secretaries International Association, A Proposal to the World Trade Organization from CSIA For the Creation of a New Separate Heading in the Services Sectoral Classification List to be titled Corporate Governance, Compliance and Secretarial Advisory Services, 2012, available online.
} 
confirm. $^{399}$ If only $1 \%$ of incorporations deal with non-Hong Kong companies (ie offshore), we can assume that new regulations would impact on the "expected value" of only 2 firms and US\$10m in revenues. ${ }^{400}$ If these new regulations choke off even $20 \%$ of this business, Hong Kong still only loses about \$2 million - hardly a huge dent in an industry worth over US\$1 billion. Yet, the undeniable conclusion remains. As roughly 35\% of all newly incorporated businesses drop out after some time, one must question the long-term effectiveness of these incorporation agents.

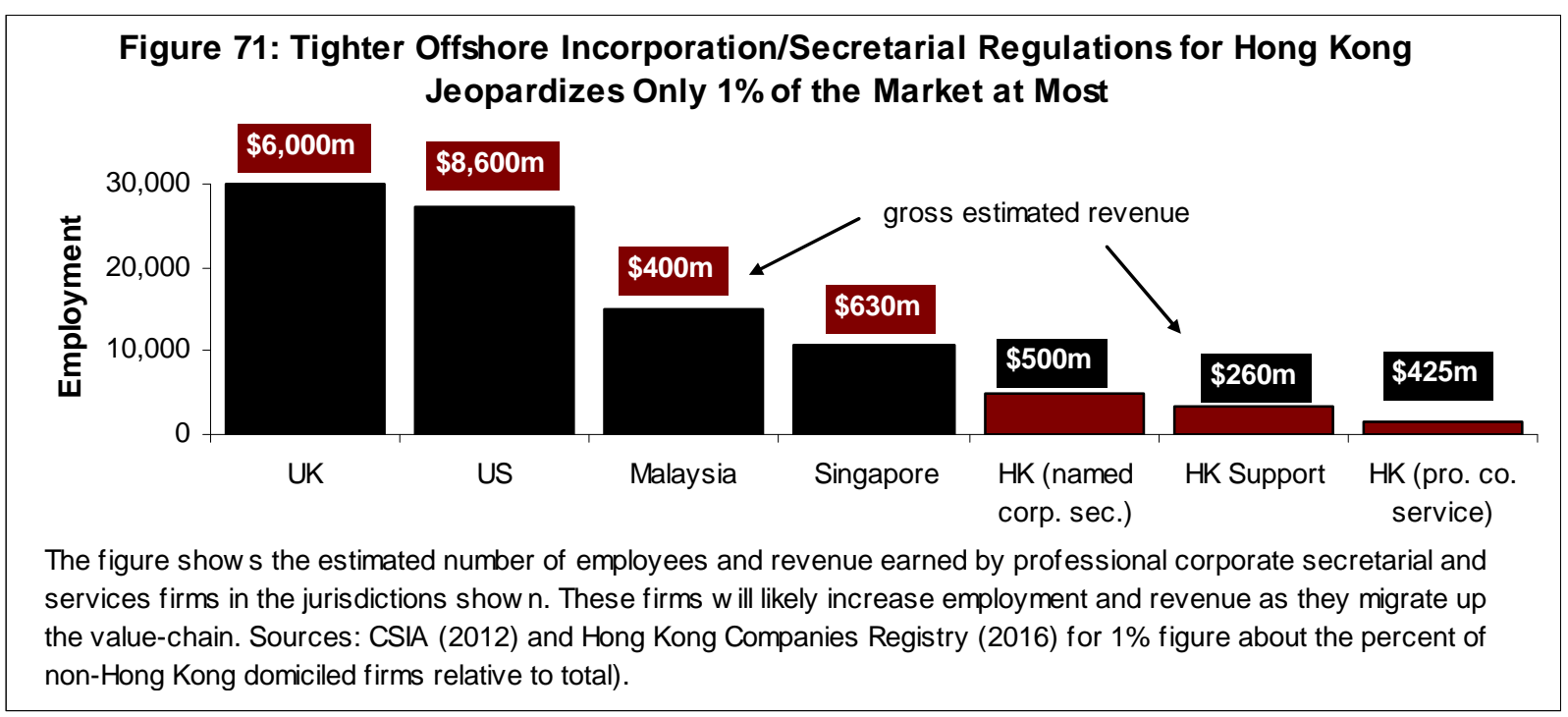

What would the remaining incorporation agents morph into? Figure 72 shows an example of a large international company handling incorporations in Hong Kong. As noted in the figure, PricewaterhouseCoopers $(\mathrm{PwC})$ provide a range of services - from advising on incorporation to complex corporate matters like accounting, restructuring, and compliance across borders. ${ }^{401}$ Simply complying with the HKICS’s AML Charter will push equilibrium employment and compliance expenses in these companies higher - pushing out the smaller and less competitive firms. ${ }^{402}$ Even paying for Thomson Reuters' World-Check (the industry standard for checking individuals' background information) will pose a problem for the smaller firms in the incorporation market. ${ }^{403}$ A firm like the Hong Kong Institute of Chartered Secretaries could help inform incorporation agents of all sizes about the factors shaping their market - and provide advice to those having to pivot (change) their service offerings or exit the market. As such our

\footnotetext{
${ }^{399}$ Including outliers (for the very large incorporation agents), average employment sizes for these 1,100 companies approaches 10 employees per firm. Such an estimate roughly matches the CSIA estimate, after allowing for rounding errors in both the CSIA and HKTDC data. Thus, if the CSIA's employment data matches the real situation in Hong Kong, we can feel more confident that the revenue data does as well.

${ }^{400}$ Expected value relates to a statistical concept whereas estimated employment and revenue come from the percentage change in incorporations multiplied by employment numbers and/or revenue amounts.

${ }^{401}$ Regulators like the Companies Registry have only recently started to measure the more complex aspects of Hong Kong's incorporation markets. See Hong Kong Companies Registry, Analysis of Statistics of Companies Incorporated, 2016, available online.

${ }^{402}$ See HKICS, AML/CFT Charter, 2016, available online.

${ }^{403}$ For more information on World-Check, see Thompson Reuters, Thomson Reuters World-Check, 2015, available online.
} 
thirty-first recommendation encourages the Hong Kong Institute of Chartered Secretaries specifically to offer workshops explaining how the changes to Hong Kong's corporate governance rules will change the nature of competition in Hong Kong's corporate secretarial services sub-sector. Firms that offer a fuller range of services - like helping Mainland and other companies adopt corporate governance reforms - will remain more competitive than the simple incorporation service providers handing out leaflets about their company on the Wanchai pedestrian walkway/bridge.

\section{Figure 72: The Global Big Audit/Consultants Will Likely Dominate Hong Kong's Future} Company Incorporation and Services Sector

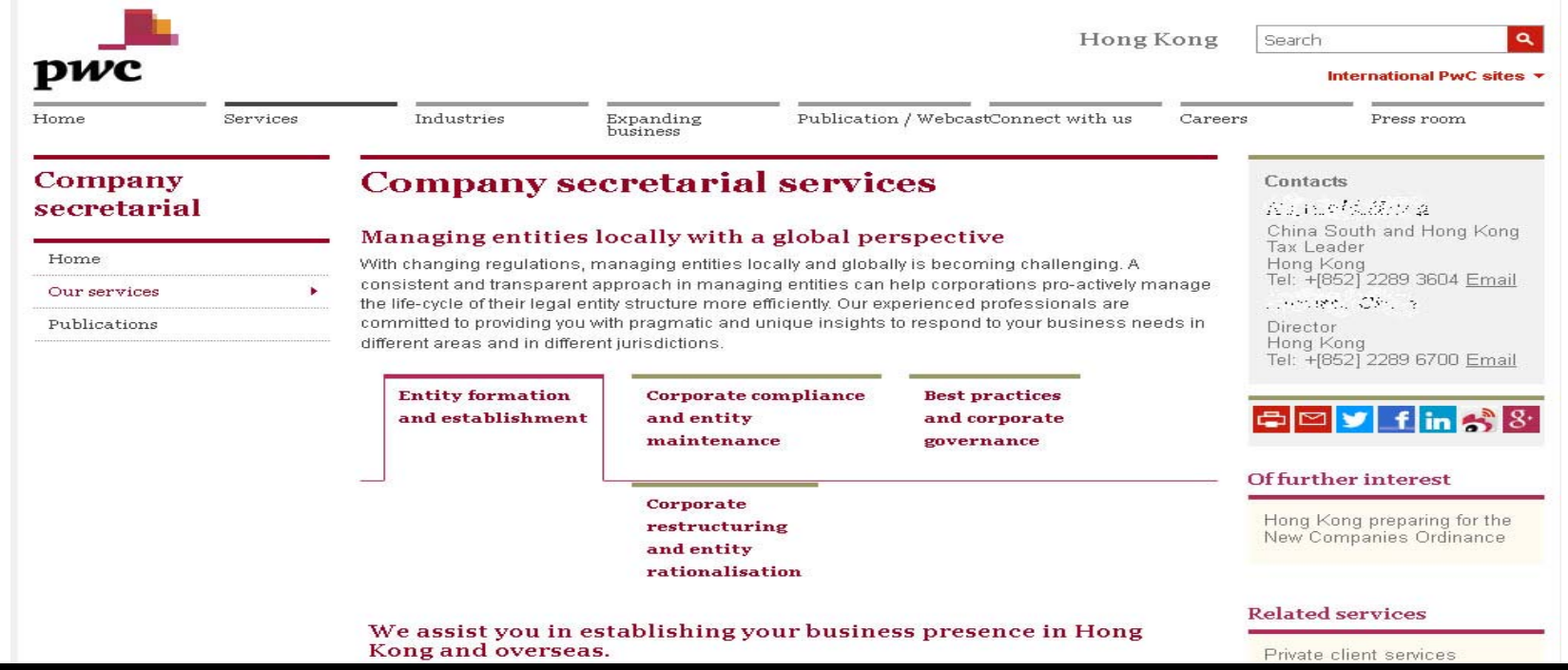

The figure shows the secretarial services offering of one of Hong Kong's larger firms operating in the corporate incorporation and secretarial advisory sector. We have no particular reason for choosing this specific company rather than its competitors of the same size and service offering.

Source: PwC website, 2016.

Recommendation 31: The Hong Kong Institute of Chartered Secretaries to conduct workshops preparing small incorporation agents and intermediaries to move up the value chain or exit the market.

\section{Conclusions}

Hong Kong contributes to poor corporate governance on the Mainland. We show how Chinese companies have used Hong Kong's stock exchange and its offshore incorporation agents to raise money and ship it off again offshore. We also showed that poor corporate governance standards often prevail in places and companies using these financial networks. The Mainland's politicisation of its corporate governance as well as its lower corporate governance standards have provided weak incentives to improve corporate governance at home. Yet, simply adopting Hong Kong's corporate governance laws on the Mainland will not improve the corporate governance we care about most - the governance that improves shareholder returns. So what can Hong Kong's policymakers do? 
Hong Kong can adopt legal provisions already common in more advanced jurisdictions. These provisions help investigators and prosecutors police firms far away from the stock exchange's gaze. These provisions also force all companies to provide more information - solving the usual collective action problems which keep listed companies' businesses dark and its shares unprofitable. These reforms would also improve Hong Kong's own corporate governance, a boon for its own companies as much as those across its northern border.

Taking on the role as policy advisor, we discuss ways to incentivize Mainland firms to improve their corporate governance by adopting numerous market-value increasing reforms in Hong Kong. These include the limited extra-territorial application of corporate governance provisions, changes to the Listing Rules to 'contract' for better corporate governance, and incentives to collect better corporate governance data. Other reforms include increasing financial transparency (particularly about corporate ownership and control), reducing financial firms' incentives to trade in shell corporations, regulating relationships with tax havens, and encouraging the redrafting of China's 2002 Code of Corporate Governance. We provide 31 recommendations and estimate that these recommendations can increase market values on the Mainland by $7 \%$ (or in value of roughly $\$ 330$ billion), while improving the value-added of Hong Kong’s own incorporation/corporate services companies.

On a more academic side, we looked at patterns in two key datasets. First, we analysed the Panama Papers data to identify the links between Hong Kong and its likely contribution to corporate governance stifling offshore incorporations abroad. We looked empirically at the link between corporate governance quality and changes in a part of the offshore incorporation market served by Mossack Fonseca. Second, we looked at the way Mainland share prices responded in the past to Hong Kong's own corporate governance reforms. With these data, we could predict how they might react to future reforms.

Lastly, we assessed many of the new issues which will dominate both the academic and practical sides of corporate governance work in the next decade or two. We looked at the likely role of beneficial ownership databases in China and Hong Kong. We looked the distance covered in our field of corporate governance between China's 2002 code of corporate governance and its analogue, as reformed in Hong Kong 2012. Probably most importantly, as jurists, we tackled the role of extra-territorial application of corporate governance. We remember when our colleagues would heckle any mention of such a thing for fighting corruption. The boring realities to tomorrow do really sometimes start with the wild speculations of today. 